Szegedi Tudományegyetem

Bölcsészettudományi Kar

Irodalomtudományi Doktori Iskola

Kőhalmi Péter

\title{
Testet öltött gondolatok
}

Erdély Miklós, konceptuális múvészet, pop art

Doktori értekezés

Témavezető:

Dr. Füzi Izabella 


\section{Tartalom}

BEVEZETÉS

ELŐSZÓ

A SEMMI FELÉ

A Marly tézisek mint montázs $\quad 15$

A Marly tézisek mint költői kiáltvány $\quad 27$

A Marly tézisek mint (nem) konceptuális müalkotás 36

$\begin{array}{lr}\text { A SEMMI FELÖL } & 87\end{array}$

„A SZÉPSÉG SZABAD AKAR LENNI...” POP ART, KONCEPTUÁLIS MÜVÉSZET, POLITIKUM: ERDÉLY MIKLÓS ÉS SZENTJÓBY TAMÁS PROGRESSZÍV MUNKÁI A ’60-AS ÉVEK MÁSODIK FELÉBEN 112

Szelíd, de nem súlytalan $\quad 114$

Erdély Miklós és Szentjóby Tamás $\quad 129$

LEZÁRÁS 196

FELHASZNÁLT IRODALOM 205 


\section{Bevezetés}

Az Erdély Miklóssal való találkozás egy igen összetett terepen mozgó alkotóval, egy igen szerteágazó életmüvel és egy terebélyes, ám az életmű gondolati és mediális sokrétűségéhez mérten némileg mégis egyenetlen recepcióval való találkozást jelent. Ezért, mintegy a disszertációm elöljárójaként, az alábbiakban szeretném kontextusba helyezni az Erdély kapcsán kibontakozó diskurzus legsarkalatosabb pontjait. $^{1}$

Erdély Miklós életművének értelmezésében és recepciójában, illetve az œuvre hozzáférhetővé és kutathatóvá tételében az első lényeges pont Beke László Erdély Miklós címü írása, mely a Híd folyóirat 1982. évi 3. számában jelent meg, s melynek bővített változata Erdély egyetlen, még életében megrendezett egyéni gyűjteményes kiállításának katalógusában kapott helyet, Erdély Miklós munkássága - Krono-logikai vázlat képekkel 1985-ig címen. Beke László ezen írása, habár nem vállalkozik értelmezésre, máig a legteljesebb képet nyújtja Erdély Miklós életművéről. A katalógusban Beke László Krono-logikai vázlata mellett Szőke Annamária és Peternák Miklós írásai olvashatók: Erdély Miklós festészetéről; Hol kezdjem? Előbb... A gyüjteményes kiállítás az Óbuda Galériában volt látható 1986. április 11. és május 5. között, melyen Erdély Miklós, egészségi állapota miatt már nem lehetett jelen. 1986-ig az életmü értelmezésének mindössze egyetlen csomópontját említhetjük: a Magyar Mühely 1983. júliusi számát, Bartholy Eszter Erdély Miklós: Bújtatott zöld,

1 A disszertáció a TÁMOP-4.2.2.B-15/1/KONV-2015-0006 számú projekt, valamint az Artpool Mủvészetkutató Központ támogatásával készült. 
Beke László Lényegi kiegészítések egy megíratlan Erdély Miklósmonográfiához (Módszertani fikcióesszé), Beke László Erdély Miklós: Partita, Enyedi Ildikó Egy pedagógiai technika (Az 1977/78. évi Fantáziafejlesztő gyakorlatok módszerének elemzése), Halász András Közvetítés pohárban, Hegyi Lóránd Az antimüvészet pályái és Erdély Miklós helyzete, Kozma György Egy film elemzése és általánosságok a filmelemzésről, Murgács Gábor Hozzászólás Erdély Miklós Marly-i téziseihez (Nyílt levél), Perneczky Géza A ferde mennyország, Peternák Miklós Álomreakció/Álommásolat [Helyesen: Álomrekonstrukció/Álommásolat], valamint Tábor Ádám Váratlan! Kérdés! címü írásaival.

Erdély Miklós távozása után az œuvre recepciója elsősorban az 1991-ben, majd az 1998-ban megrendezett életmü-kiállítása kapcsán kapott nagyobb lendületet, illetve Erdély három kötetbe rendezett verseinek, téziseinek, mủvészeti és filmes írásainak posztumusz megjelenésekor. Erdély Miklósnak mindössze egyetlen verseskötete jelenhetett meg életében, a párizsi Magyar Mühely által 1974-ben kiadott Kollapszus orv. Ezt követi az Erdély Miklós Alapítvány tagjainak gondozásában 1991-ben megjelent Második kötet és Müvészeti írások (Válogatott müvészetelméleti tanulmányok I.), majd 1995-ben A filmről (Filmelméleti írások, forgatókönyvek, filmtervek, kritikák) Válogatott írások II. Az 1991-ben Székesfehérvárott, a Csók István Képtárban és István Király Múzeumban megrendezett kiállítás katalógusának tanulmányát Perneczky Géza írta, Erdély Miklós, és müve, a dekonstruktív tautológia címen, a hét évvel későbbi, 1998-as Műcsarnok-beli kiállításnak pedig, habár nem jelent meg katalógusa, az ennek alkalmával szervezett szimpóziumon felszólalók előadásait a Magyar Mühely 1999. évi 110-111. száma közölte. 
Mindezeken túl az életmü kutathatóvá tételének és recepciójának főbb állomásaiként különböző rendezvényeket, tematikus folyóiratszámokat, egy nagyobb ívű kutatás eredményét, illetve sporadikusan megjelenő tanulmányokat említhetünk. Időrendben haladva a BBS Mozgó film 1-2. címü műhelykiadványait 1984-ből és 1986-ból, A Tartóshullám antológiájának interjúit (Jóvilág 3.) (Cápa 4.) 1987-ből, a Szkéné Színházban megrendezett Erdély Miklós emlékmüsort 1987-böl, a Kossuth Klubban megrendezett Erdély Miklós emlékestet 1988-ból, a TIT, a BBS K-szekciója és a Budapest Film által a Kossuth Moziban szervezett ankétot, valamint az ennek kapcsán megjelent Erdély Miklós (1928-1986) Filmek/Films címü katalógust 1988-ból, a Beszélő 1991. októberi számának mellékletét, az Artpool Müvészetkutató Központ Erdély Miklós évét és Önösszeszerelő délutánjait 1994-ből, a Balkon 1998. októberi számát, az Artpool Müvészetkutató Központ Kamilla-napjait 1999-től, a 2006-ban Szegeden megrendezett Szunnyadás című filmes konferenciát, melynek anyaga a Metropolis 2007. áprilisi számában jelent meg, az MKE Intermédia Tanszékén az Erdély Miklós Alapítvány által 2008-ban szervezett Erdély 80|80 című szemináriumot, a Puskin Utca 2008. évi 4. számának interjúit, valamint a Parnasszus 2011. évi 3. számát. Külön kell említeni Szőke Annamária és Hornyik Sándor 2008-ban megjelent, Erdély Miklós művészetpedagógiai gyakorlatának egészét átölelő kötetét: KREATIVITÁSI GYAKORLATOK, FAFEJ, INDIGO - Erdély Miklós müvészetpedagógiai tevékenysége 1975-1986.

Mindezeken túl pedig föként a következőket: Pályi András: Happening és színház Gondolatok a „Három kvarkot Marke királynak!” kapcsán (1969); Perneczky Géza: Új müfaj: A fotómozaik (1970); Peternák Miklós: A konceptuális müvészet hatása Magyarországon (1983-85); Beke 
László: Film Möbius-szalagra Erdély Miklós munkásságáról (1987); Peternák Miklós: Erdély Miklós 1928-1986 (1988); Kovalovszky Márta: Erdély Miklós: Időutazás (1988); Szőke Annamária: Tapogatózás legyen (1989); Szőke Annamária: piros fehér zöld (1989); Ágh István: Virágárok (1989); Petőcz András: Jegyzet Erdély Miklósról (1990); Kovalovszky Márta: 1987 őszén: Don Giovanni II. (1991); Forgács Éva: „.. a nem elvárható dolgok megjelenitése" Erdély Miklós életmükiállitása (1991); Peternák Miklós: Beszélgetés Erdély Miklóssal 1983 tavaszán (1991); Erdély Dániel: „Mi kis” életünk (1991, 1992); Erdély Dániel: Mi kis családunk (1992); Forgács Éva: A neoavantgárd magánya Erdély Miklós: Müvészeti irások (Válogatott müvészetelméleti tanulmányok) (1992); György Péter: Erdély Miklós - A szelíd botrány müvésze (1992); Babarczy Eszter: Határátlépő Erdély Miklós (értelmezési kisérlet) (1992); Kurdy Fehér János: Kamillába mártott vatta (Beke László Erdély Miklósról) (1992); Szőke Annamária: „,Titok a jövő jelenléte” Tudomány a müvészet határain belül Erdély Miklós müvészetében (1997); Bihari László: Kiveszőben lévő mentalitás (Beszélgetés Beke Lászlóval és Peternák Miklóssal) (1998); Sugár János: Emigráció a festészetbe Erdély megvalósult és meg nem valósult müvei (1999); Tillmann J. A.: „Nem hiszem, hogy még egy ilyen ember van a világon.” Erdély Miklós és A kalcedoni zsinat emlékére (1999); Szőke Annamária: Erdély Miklós: Tavalyi hó 1970 (2000); Peternák Miklós: Rejtett Paraméterek Erdély Miklós elveszett filmjei (2001); Peternák Miklós: Interdiszciplinaritás Új médiumok az elmúlt három évtized magyar müvészetében - vagy kire hatott Erdély Miklós és kire nem? (2002); Hornyik Sándor: Naiv realizmus és „természettudományos koncept” A modern természettudomány helye Erdély Miklós müvészetében (2004); Hornyik Sándor: A fekete lyukak esztétikája 
Kritikai teória és praxis Erdély Miklósnál (2006); Hornyik Sándor: Avantgárd kvarkok Erdély Miklós: Három kvarkot Marke királynak (2006); Boros Géza: Leletmentés Erdély Miklós fotómozaikjai (2014). 


\section{Előszó}

Erdély Miklós a XX. század második felének minden bizonnyal az egyik legjelentősebb és legsokoldalúbb magyar alkotója - hangzik az utóbbi harminc évben sokak által leírt megállapítás Erdély életművének jelentőségéröl, mellyel mi is teljes mértékben egyet érthetünk. Azzal a kiegészítéssel, hogy jól tesszük, ha ezt a mondatot térben és időben is kiterjesztjük. A megállapítás ugyanis könnyen meglehet, hogy nem csupán a XX. század második felének művészetét szemlélve érvényes, ahogy az is valószínünek tủnik, hogy Erdély Miklós életmüvének jelentősége túlmutat az országhatárokon. Súlyához illő helyét talán inkább találhatjuk meg a kelet-európai régió egyik legfontosabb alkotójaként, mi több azon is túllendülve, s némileg más szemléletet felvéve, a globális tendenciák áramlataiból kiemelkedő legjelentősebb és legjellegzetesebb alkotók között.

Erdély Miklós jelentős és nagy hatású alkotó. Azonban a távozása óta eltelt harminc évben, habár több hullámban nagyobb erőfeszítések gyürüztek munkásságának megértése körül - kiállítások, különböző rendezvények, tematikus folyóiratszámok vagy akár hosszabb, kitartó kutatás eredményei pezsdítették fel időről-időre a körülötte zajló diskurzust, az életmű egy-egy lényeges szeletének és aspektusának recepcióját élénk mozgásba hozva -, az œuvre egészét átfogó munka máig sem született. Erdélyről írva így nem tehetjük meg, hogy megkerüljük a kérdést: mégis, miért alakulhatott ez így? A kérdésre adható válaszom nagyon is egyszerü: erről feltehetően maga Erdély Miklós „tehet”. Erdély Miklós, a különösen felszabadult érdeklődésével minden kifejezési eszköz 
iránt, a szakadatlan megújuló, zavarba ejtően sokrétü, szinte egybefoghatatlan életmüvével, s persze azzal, hogy életmüvének értelmezője számára nem elegendő a munkáit követni, azokat csakis a teóriájához közelebb kerülve lehet együtt látni. Erdély márpedig legalább annyira volt gondolkodó, mint képzőművész. A többirányú mediális kísérletezések mellett életmüvét a gondolatiság, a gondolatok tartják egyben - amire a lehető legtágabban értelmezett interdiszciplinaritás jellemző. Erdély életművét követve ezért nem elég ismernünk az időszak müvészetének kurrens elméleteit és a klasszikus nyugati bölcselet hagyományát, feltétlenül nyitnunk kell a világ megismerésének különböző, többnyire egymástól is elszeparált módozatai felé: akár a természettudomány legkülönbözőbb előterjesztései, akár a kreativitás pszichológiája, de egyúttal a szakralitás, a zen buddhizmus, a zsidókeresztény hagyomány és a spiritiszta dimenziók irányába is. Erdélyt követve nem léteznek határok a világ megismerésének különböző módozatai között. Pontosabban a válaszfalak nem a megismerés különböző, már bejáratott útjai között húzódnak, hanem egyetlen helyen, a már ismert és a még ismeretlen határán. $\mathrm{S}$ az értelmező számára az igazi nehézség ebben rejlik. Abban, hogy a különállók territoriális határait lebontva ne azok egymásba záródó összegéhez érkezzen meg, hanem a megismerhetők egymást bővítő horizontjának repedező pereméhez, s legalább néha azon is túlra, a még ismeretlenhez. Helyzetünk tehát közel sem olyan egyszerü Erdély életművéröl beszélve, hogy egyetlen tömör mondatban leírható legyen. Munkássága ugyanis egyfelől nagyszerü példája annak, hogy a megszületett alkotások egyben új utakat nyitó javaslattételek a médiumok használatára, másfelől életműve annak is kivételes példája, hogy a létrejött artefactumok egyszersmind variációk is a gondolatok tapinthatóvá váló 
emanációjára. S Erdély alkotásai határozott mozdulatokkal fordítják ki mind a jól bejáratott, rutinszerủen használt kifejezési formákat, mind pedig a megülepedett gondolkodási sémákat, hogy a kötöttségek fellazításával készítsenek elő terepet az új, a még ismeretlen számára.

Disszertációm első nagyobb egységében a semmi, az üres jel felé haladva három irányból közelítem meg Marly téziseket. Három olyan megközelítésben írok a tézisekről, amely egyáltalán nem szokványos. Az első két rövid fejezetben az eddigi recepcióhoz mérten más összefüggésben helyezem el a téziseket mind a müvészet fogalmáról való gondolkodás teoretikusan lehetséges variánsai között - pontosabban nem máshol helyezem el a téziseket, hanem egyáltalán elhelyezem a variánsok között -, mind pedig az életmű belső törekvéseiben. Ebből adódóan Erdélyolvasatomat ezekben a fejezetekben elsősorban nem a szűken értelmezett Erdély-recepcióval léptetem közvetlen diskurzusba, hanem a művészetről való gondolkodás különbözö változataival, rámutatva mindeközben az életmü belső összefüggéseire is. Előbb meghatározom a téziseket mint montázst, aztán pedig mint költői kiáltványt.

A harmadik fejezet lényegesen hosszabb. Ez a Marly tézisekről mint nem konceptuális müalkotásról szól. Azaz, kérdőjelet tesz Erdély recepciójának az egyik legstabilabb állítása mellé. A recepció jelen állása szerint ugyanis Erdély Miklós a konceptuális müvészet kiemelkedő alakja. Ebben a fejezetben ezt az állítást járom körbe, igazolom és cáfolom több ponton. Elöször is szorosan egymás mellé helyezem Joseph Kosuthot és Erdély Miklóst. (A honi elméleti szakma ekkor, ahogy Erdély is, a konceptualizmusról, a konceptről, a concept artról és a conceptual artról, az ötletmüvészetről, a fogalomművészetről és a fogalmi müvészetről beszélve többnyire Joseph Kosuth szükebben vett, analitikus konceptual art- 
értelmezését és munkáit tartotta mérvadónak.) Tehát visszamegyek a gyökerekhez, és szorosan olvasok. Kosuth és Erdély gondolatait veszem közelebbről szemügyre: bemutatom törekvéseik rokonságát, majd a kettejük szemléletmódja közötti különbségeket. Mindezzel pedig azt igazolom, hogy a Marly téziseket a kosuthi törekvések alapján feltétlenül mủalkotásnak kell tekintenünk. Egyfelöl. Másfelöl pedig azt, hogy Erdély a tézisekben a konceptuális müvészet Kosuth-féle meghatározásából kifelé tekint. Hogy, habár mindketten analitikus szemléletből indulnak ki, Erdély a kosuthi törekvések határait átlépve mégis kontinentális terepre érkezik. Pontosan oda, amitől Kosuth a szándékai szerint elhatárolódik. És csak így, ezzel érkezhetünk meg ahhoz a talajhoz, amelyen Erdély Miklós œuvre-je adekvát módon megközelíthetővé válik. Innen végigkövetve Erdély '80-as évekbeli munkáit pedig azt láthatjuk, ahogy az „ortodox” konceptuális művészet szellemi purizmusa helyett a nyughatatlan mediális kísérletezései során végül még az addig elutasított „egyszerü és báva” festészethez is megérkezik - persze a sürü, vibráló gondolati indíttatást nem elhagyva, és valahogy, de mégsem csatlakozva az ekkor jelentkező új festészeti tendenciákhoz. S hogy mindennek alapján mit mondhatunk Erdély munkáiról? A fejezetet zárva összegzéseként azt a kérdést teszem fel, hogy mennyiben lehet lefedni az időszak mára már stabilizálódott müvészettörténeti kategóriáival Erdély Miklós mediális kísérletezéseit. A válaszom, hogy a kategorizálással, a szükebbre méretezett vagy éppen tágabb fakkokkal nem feltétlenül kerülünk közelebb Erdély folyamatos irányváltásaihoz. Összegzésként azt mondom, hogy Erdély fluidumszerü életműve tökéletes példája annak, ahogy a Marly tézisek koncepciója zárójelezi a müalkotás és a müvészet stílustörekvések, irányzatok, tipizálható magatartás- és szemléletmódok mentén történő 
értelmezhetőségét. Ahogy a tézisek a müvészettörténeti rekonstrukciók kategóriáit szétfeszítve a müvészet minden külsődleges értelmezési kényszertől mentes autonómiájára irányítják a tekintetet. És persze azt, hogy éppen ez a bármiféle megszokásból és hierarchiából kivezető út az, ami miatt a Marly tézisek és Erdély életműve utólag igazán kiemelkedőnek, maradandónak, a naptári időszámítástól és a múlékony stíluskategóriáktól is függetlennek bizonyulhat.

A következő fejezet teljes egészében új megközelítést vezet be. Eddig a semmi, az üres jel felé haladtam, itt viszont megfordítom az irányt: azt vizsgálom meg, hogy a semmi felöl mit mondhatunk minden másról és persze magáról a semmiről. Ennek során pedig kiderül majd, hogy a „semmi” nagyon is „valami”. Erdély teóriájának közkeletü értelmezése szerint a műalkotással való találkozás a megcsontosodott gondolati sémák kilazításán és a fogalmiság feloldásán át tarthat az üresség felé. Az ürességet természetesen kezelhetjük utópiaként, s ezzel a mozdulattal akár a végtelenbe is odázhatjuk, de arra a kérdésre is kereshetjük a választ, hogy mi legyen az egyszer mégiscsak elért üresség után, mivel töltsük majd fel az üres helyet. Az üresség azonban csupán ezekből az irányokból meghatározhatatlan. A semmitől távolodva, ha visszapillantunk rá, láthatjuk úgy is, hogy ez volt mindennemü megértés legstabilabb kiindulópontja. Ebben a fejezetben két lényeges, egymást bővítő kontextust emelek be az értelmezésbe. Az egyik a klasszikus német idealizmus, pontosabban Schelling és Hegel néhány gondolata. Ennek kettős tétje van. Egyfelől így bomlik ki a korábban leírtak egy vetülete: az, hogy Erdély erős szálakkal köthető a klasszikus, kontinentális gondolkodáshoz is. Ami pedig nem csupán a konceptuális művészet törekvéseinek függvényében fontos, hanem akkor is, amikor némely értelmező Erdélyt a posztmodern 
honi előhírnökeként könyveli el. Az ide vonatkozó tézisem szerint egymás mellé helyezhető Erdély semmije és Schelling abszolútuma. Ha pedig egymás mellé helyezzük a semmit és az abszolútumot, pontosabban azt, hogy Erdély és Schelling milyen kategóriák mentén, illetve hogyan határozza meg sajátját, láthatóvá válik a rokonságuk. Ami a rokonság tényének megállapításán túl természetesen Erdély üres terének értelmezésében is segít. Itt két út kínálkozik a folytatásra. Az egyik az abszolútum történetének, különböző elgondolásainak felvázolása, a másik pedig a felmutatott rokonság árnyalása, s egyúttal az életmü egy meghatározó törekvésének bemutatása. Ez utóbbit választom. Maradva Erdély életművénél és a jelölt kontextusnál egy markáns különbségre mutatok rá. Egy olyan lényeges eltérésre, mely egyben Erdély életművének az egyik meghatározó sajátja: a művészet és a szakralitás elválasztottságának új egységbe olvasztása. A másik kontextus tehát, amit ebben a fejezetben emelek be az értelmezésbe, a szakralitás. A semmi megérintése ugyanis a semmiből való teremtés és teremtettség átélésének is a lehetősége. S ez Erdély életművében nemcsak a genezis keresztény hagyományát eleveníti fel, hanem zsidó, pontosabban kabbalisztikus haszid zsidó dimenziókba is átvezet. A világteremtés Jichak Luria Askenázi-féle kabbalista tanát továbbvivő haszidizmus Erdély munkáinak az egyik fontos kontextusa. Ebben a fejezetben Erdély teóriájának talán legmélyebb magvát párhuzamosan mutatom be ide vonatkozó alkotásaival: fotómunkáival, akcióival, installációival, environmentjeivel.

Lezárásként egy történeti ívet nyitok meg. A pop art, a konceptuális művészet és a politikum viszonyát követem végig Erdély Miklós és Szentjóby Tamás 1960-as évek második felében született progresszív munkáit szemlélve. Erdély már 1968 júliusa előtt úgy fogalmaz 
Pop tanulmányában: „A szépség szabad akar lenni: önmaga. Méginkább: a szabadság szép akar lenni - önmaga - és | mindenre vonatkozni egyszer.”² S szintúgy ebben a tanulmányban jósolja a következőt: „Nem lehetetlen, hogy a közeljövő legelterjedtebb művészete a tüntetés lesz.”³ Ez a nagyobb egység egészen közvetlenül azt a kérdést szeretné megválaszolni, hogy a szabadság Erdély-féle teóriája milyen viszonyban áll korának politikai berendezkedésével. Azaz, ha számára a szabadság elsőszámú letéteményese a müvészet, akkor pontosabban milyen a müvészetének az őt körülvevő politikumhoz, a szabadság aktuális lehetőségeihez való viszonya? Válaszolni pedig erre csak úgy lehetséges, ha figyelembe vesszük alkotásainak kontextusát: politikumhoz füződő sajátságos viszonyát úgy érthetjük meg árnyaltabban, ha nem csupán az ő alkotásait vesszük sorra, hanem beillesztjük azokat az egykorú művészet közegébe is. Ebben az egységben azt mutatom be, hogy a '60-as évek második felének avantgárd müvészetéhez mérten Erdély Miklós alkotásai közel sem súlytalanok, azonban mégis „szelíd állapotot” tükröznek. A szelídség persze viszonylagos. Annak bemutatására, hogy mihez képest is szelíd, kitérek a neoavantgárd kezdeti időszakának csoportos fellépéseire, és közelebbről szemügyre veszem Szentjóby Tamás ekkori munkáit. A legstabilabb kapaszkodó gyanánt ragaszkodni fogok Erdély munkáinak időrendben való csoportosításához. A feltett alapkérdésem - mennyiben tekinthetjük politikai, társadalomkritikai munkáknak Erdély alkotásait megválaszolásához nélkülözhetetlen egykorú müvészeti tendenciák

\footnotetext{
${ }^{2}$ Erdély Miklós: Pop tanulmány. In: Erdély Miklós: Müvészeti írások. (Válogatott müvészetelméleti tanulmányok I.). (A továbbiakban: MI.) Szerk. Peternák Miklós. Képzőművészeti Kiadó, Budapest, 1991. 36. o.

${ }^{3}$ Uo. 34. o.
} 
felfejtésekor szintúgy törekedni fogok a minél pontosabb, akár évekre lebontható egyidejüségre. Viszont a két stabil támponttal élve a célom összességében mégis az, hogy ezekbe kapaszkodva, ám az innen kinyúló indákat végigkövetve Erdély életművének finomabb összefüggéseire és össze-nem-függéseire mutassak rá. Az alapkérdés és az arra adott válasz tehát nagyon is fontos. Azonban legalább ilyen lényeges, ami út közben történik. A kérdést megválaszolom, ám út közben jó néhány, legalább ilyen lényeges pontját, hangsúlyát és belső összefüggését emelem a felszínre Erdély életmüvének, illetve az életmü szükebb-tágabb kontextushoz füződő viszonyának. Természetesen ebben a fejezetben is tovább bővítem az értelmezés terepét. A teóriától az élet felé közelítve foglalkozom az időszak aktuális történéseivel, honi és nemzetközi eseményeivel, a csehszlovák történésektől az új gazdasági mechanizmusig vagy éppen a Kádárkorszakban egyszerre létező és mégsem létező „zsidókérdés”-ig. A disszertáció egészére szétosztva, fokozatosan bővítem az értelmezést a természettudomány előterjesztéseivel, s ez alól ez a fejezet sem kivétel. Mindezeken túl pedig ebben a fejezetben érintem az életmü spiritiszta vonatkozásait is.

Disszertációm tehát Erdély Miklós életművének két, időben jól behatárolható szakaszára koncentrál. Egyfelől az 1960-as évek második felére, azaz a neoavantgárd címszóval egybefogott törekvések kezdetére, mikor is Erdély a színrelépése első momentumaival már rögtön egy erős, érett, eredeti és szokatlan szemléletet vitt a magyar müvészeti életbe. Dolgozatom másik fókuszpontja Erdély Miklós 1980-as évekbeli gondolatai és alkotásai. Ez az időszak egy kivételesen sürü alkotói periódust jelent életmüvében s egyszersmind a '60-as évek derekától formálódó teóriája kiteljesedését. Disszertációm nem kronologikus 
sorrendben közelíti meg a két periódust. Előbb Erdély '80-as évekre kikristályosodott teóriáját mutatja be a Marly téziseken keresztül, hogy innen nyisson rálátást tárgyiasult gondolataira, s így, már a konkrét alkotásokra fókuszálva illessze be törekvéseit az avantgárd sokszínü mozgalmasságába. Dolgozatom arra törekszik, hogy a két, időben jól behatárolható perióduson keresztül minél több, még felszínt nem ért hangsúlyát és összefüggését bontsa ki Erdély életmüvének, s hogy mindezzel, még ha jó néhány ponton fel is kavarja Erdély recepcióját, hozzájáruljon az œuvre átfogó értelmezéséhez. 


\section{A semmi felé}

„NINCS VAN, DE NINCS VAN.”

\section{A Marly tézisek mint montázs}

Arra a kérdésre, hogy mi a művészet, Erdély Miklós legtömörebben a Marly tézisekben válaszol, melyet az 1980-as, Párizs közelében, Marly-le-Roi-ban rendezett Magyar Mühely-találkozón olvasott fel. Tézisekbe sürített válasza a paradoxonok felforgatóerejét használó gondolkodás letisztult, kikristályosodott összegzése.

A kérdésre természetesen már sokan, sokféleképpen próbáltak válaszolni, ám a válaszkísérletek hosszas felsorolása, aprólékos tipizálása, és Erdély pozíciójának ebben a komplex viszonyrendszerben történő elhelyezése helyett csupán egyetlen kísérletet említek majd: Morris Weitz teóriáját. Mielőtt azonban belesétálnánk a tézisek útvesztőjébe, legalább két, már jól kitaposott utat tisztán kell látnunk. Két, határozottan más irányba tartó törekvést.

A két ösvényt a kérdés más-más, egymástól markánsan elkülönülö megközelítése járta ki. Az egyik egy, a klasszikus német idealizmus talajáig visszanyúló, összegző irányultságú, kontinentális problémakezelés, míg a másik egy angolszász, analitikus, többnyire értéksemleges megközelítés. Ez utóbbi szerint azt, hogy mi könyvelhető el művészetként,

4 Erdély Miklós: Nagy számok. In: Erdély Miklós: Kollapszus orv. (A továbbiakban: KO.) Magyar Mühely, Párizs, 1974. 104. o. 
a rá vonatkozó értelmezés kontextusa dönti el. Azaz, ha van olyan értelmezés, amely mütárgyként határoz meg egy tárgyat, akkor az egyszerüen mütárgy. Ebben az irányban haladva a teóriák elkülönülésének fennáll egy szélsőséges lehetősége, a teljes elaprózódás, az atomizálódás: a releváns értelmezési keretek számának a müalkotások sokaságával való megegyezése, ami a mủalkotás fogalmának teljes expanzióját jelenti. A másik, kénytelenül mind nagyobb területet behálózó út a szintézisre törekszik. Arra, hogy az időben, a térben, a művészeti ágak és az egyedi műalkotások között is széttartó esztétikai tudást - akár még az avantgárd esetében is - egységbe foglalja. Ez a vállalkozás arra törekszik, hogy létrehozza az egymáshoz mérten heterogén elméleteknek azt az átfogó szintézisét, amely minden, akár lényegileg eltérő kontextusok által meghatározott müalkotásra egyaránt érvényes. S persze ennek a szintézisnek olyannak kellene lennie, amely nem rekeszt ki egyetlen mủalkotást sem. A két út tehát: elaprózódás és a műalkotás fogalmának teljes expanziója vagy szintézis és átfogó esztétika. Persze nem feltétlenül szükséges ezek közül választanunk, léteznek köztes megoldások is. Ha nem is a mindent egybegyüjtő szintézisre törekszünk, mégis fektethetünk nagy energiát olyan pozíciók felmutatásába, ahonnan a klasszikus esztétika diskurzusának a XX. századra ellehetetlenülő alapfogalmai legalább részben használhatóvá válnak. Ha nem is az esztétikai elméletek együvé gyüjtése a célunk, rámutathatunk a különböző síkokon mozgó elgondolások érintkezési felületeire, az egymástól akár távol álló teóriákat mégis összekapcsoló közös gondolatokra. Aki a köztes megoldást választja, tudnia kell, amint halad előre, újabb és újabb elágazásokhoz fog érkezni. Ám ennek az útnak a cizellált ágrajza helyett már térjünk rá Erdély Miklós válaszára, a Marly tézisekre. 
A 'Mi a müvészet?' kérdésre adott válaszkísérletek lehetséges irányait azért volt szükséges legalább elnagyolva felvázolnunk, hogy jól lássuk, Erdély Miklós teóriája a felmutatott két szélső eset mellett egyszerre áll ki. Erdély Miklós paradox módon egyszerre beszél a müvészet fogalmának feltartóztathatatlan elaprózódásáról és mégis egy pontba sürítéséről. Egyszerre áll ki a müvészet fogalmának teljes polarizációja mellett, ugyanakkor ezt mintegy a visszájára fordítva és egy pontba sürítve mégis megad egy elvet, melyből elmélete szerint minden „respektálható” műalkotás legalább egy, ráadásul a kvalitását döntően befolyásoló jellemvonása dedukálható. Ahogy a Marly tézisekben tömören megfogalmazza:

• Ami a bevett müvészeti ágakban közös, azt érdemes müvészetnek, illetve annak lényegének nevezni.

[...]

$\bullet \bullet \bullet$ Minél különbözőbb tevékenységeket, készítményeket tekintek müvészinek, annál szűkebb az a terület, ami bennük közös.

$[\ldots]$

- Jelentős alkotónak tartom, aki hozzájárult ahhoz, hogy a különböző művészinek nevezett tevékenységekben ne legyen semmi közös.

$[\ldots]$

$\bullet \bullet \bullet[\ldots][\mathrm{K}] \mathrm{i}$ kell jelentenem, hogy hála az alkotóknak, a müvészet fogalma üres, nincs jelöltje, nem maradt jelentése. ${ }^{5}$

A művészet meghatározása így a tézisekhez írott bevezető címében összegezve:

A müvészet mint üres jel. ${ }^{6}$

\footnotetext{
${ }^{5}$ Erdély Miklós: Marly tézisek. In: MI. 125-126. o.

${ }^{6}$ Erdély Miklós: A művészet mint üres jel. In: MI. 122-124. o. A tézisekhez írott bevezető előadásként is elhangzott, azonban nem a marly-i konferencián, hanem
} 
S hogy mi történt itt? Erdély Miklós igencsak frappánsan válaszolt is a 'Mi a művészet?' kérdésre és nem is. A modális logikai leírás lehetőségeivel kicsit eljátszva azt mondhatjuk, Erdély álláspontja felől meglehetősen furcsa módon - nem eldöntendő típusú az a kérdés, hogy lehet-e válaszolni arra kérdésre, mi a müvészet. Ha pedig nem eldöntendő, nem szükségszerü választani a lehet vagy nem lehet diszjunkció tagjai közül, s ő a 'vagy' pluralisztikus értelmezései közül a megengedő értelmezést választja. Egyszerübben fogalmazva: A 'Mi a müvészet?' kérdés megválaszolása és a válaszadás lehetetlensége egy irányba tartanak. A tézisek alapján a lehet és a nem lehet nem zárja ki egymást. Mi több, Erdély teóriája az ellentmondást úgy tartja meg, hogy tagjai minél jobban szétfeszülnek, annál jobban forrnak egybe: annál inkább lehet válaszolni a kérdésre, minél inkább nem lehet. Annál inkább határozza meg, hogy mi a mủvészet, minél inkább nem lehet azt megtenni. A müvészet így lesz végül üres jel.

A tézisekben az ellentmondás-mentesség törvénye semmiképp sem érvényesülhet. A művészi tevékenységek egymástól elkülönülő sorozatának diszkrét logikai rendszere helyett a paradoxonok mindent felforgató erejével szembesülünk, azzal az új rendet felmutató mozgalmassággal, amiről Herakleitosz úgy fogalmaz: „Az ellentétesre csiszolt illik össze, [és] az ellenkezőkből a legszebb illeszkedés és minden a viszály által jön

1980. október 1-én a Magyar Képzö- és Iparmüvészek Szövetségének $A$ müvészet a változó világban (Müvészet - Antimüvészet) címen a Képzőmüvészeti Világhét alkalmából tartott konferenciáján. [Lásd még: Peternák Miklós: Szerkesztői jegyzetek. In: MI. 212. o. Ezúton is köszönöm Peternák Miklós a szöveg egészére ki- és azon is jóval túlterjedő segítségét.] 
létre.”7 Ám a művészet egymástól távoli elgondolásainak egy felületre sűrítéséről, Erdély szakrális és természettudományos dimenziókra egyaránt megnyíló életmüvét követve nemcsak a preszókratika paradoxonai juthatnak eszünkbe, hanem akár a kvantumvilág mély belső ellentmondásossága is: az, hogy lehetetlen vállalkozás tagolt nyelven egységbe foglalni a jelenségek heterogén megközelítéseit - még akkor is, ha összeférhetetlenségüket jótékony mozdulatokkal komplementer viszonyként próbáljuk egyben tartani. ${ }^{8}$ S persze eszünkbe juthat a hullámrészecske kettőség azon sajátossága is, hogy a részecskék egymással találkozva - amennyiben a hullámok csúcsai és völgyei egymás tökéletes ellentétei -, akár még ki is olthatják egymást. ${ }^{9}$ Erdély Miklós pedig a tézisekhez írt jegyzeteiben úgy fogalmaz: „Barthes támogatása nélkül jutottam el a 2., befejező, kifejezetten zen jelegü kijelentéspárhoz."10 $\mathrm{S}$

${ }^{7}$ Arisztotelész: Ethica Nicomachea. 1155b 4. In: Görög gondolkodók 1. Ford. Kerényi Károly. Kossuth Könyvkiadó, Budapest, 1993. 32. o.

8 Lásd: Niels Bohr: Biológia és atomfizika. In: Uő: Atomfizika és emberi megismerés. Ford. Nagy Tibor. Gondolat, Budapest, 1964. 24-37. o.; Uö: Ismeretelméleti kérdések a fizikában és az emberi kultúrák. In: I.m. 38-50. o.; Uő: Az atomok és az emberi megismerés. In: I.m. 123-138. o.; David Favrholdt: Niels Bohr's Philosophical Background. Historisk-filosofiske Meddelelser 63. Det Kongelige Danske Videnskabernes Selskab. The Royal Danish Academy of Sciences and Letters. Munksgaard, Copenhagen, 1992. Valamint lásd Heisenberg Fizika és a filozófia címü könyéből főként a Nyelv és valóság a modern fizikában címü fejezetet: Werner Heisenberg: Fizika és a filozófia. In: Uő: Válogatott tanulmányok. Ford. Kis István. Gondolat, Budapest, 1967. 178-197. o.

${ }^{9}$ Lásd: Dr. Marx György: Kvantummechanika. Műszaki Könyvkiadó, Budapest, 1957. 105-112. o.; Stephen W. Hawking: Az idö rövid története. Ford. Molnár István. Maecenas Könyvek - Talentum Kft., Budapest, 1998. 66-68. o., 187. o.; John Gribbin: Schrödinger macskája. Kvantumfizika és valóság. Ford. Dr. Both Előd. Akkord Kiadó, 2001. 113-117. o., 150-154. o.

${ }^{10}$ Erdély Miklós: [A tézisek mellé...] In: MI. 131. o. 
ahogy tudjuk, a zen gyakorlatok során az összeférhetetlen különbségek egymásba tartó, gyorsuló körforgása kilöki magából a logicizmust, mígnem a megértésükre törekvő megszédült erőfeszítést a nyelve is elhagyja, majd elhallgatva a szatoriban megnyugvást találhat. D. T. Suzuki összegzésében: „A zen szerint a szavak és a logika rabszolgái vagyunk.”"11 Azaz: „Amíg a logikát véglegesnek gondoljuk, meg vagyunk láncolva, lelkünk nem lehet szabad.”12 A racionálisan értelmezhetetlen koanok végül ahhoz a verbalitástól megszabaduló belátáshoz vezetnek, miszerint: „Aki tud, az nem beszél; aki pedig beszél, az nem tud.”13 Éppen akként, ahogy a mủvészet meghatározására adott válaszok együvé gyüjtve szétfeszülnek, ahogy a feltorlódó válaszok egymást kioltva ellehetetlenítik a művészet átfogó, pozitív definiálását, s ahogy végül a müvészi tevékenységek sora az üres jelet hagyja maga után mint a művészet fogalmának végsőkig megtisztult lényegét. ${ }^{14}$

A Marly tézisek Erdély Miklós teóriájához tökéletesen illeszkedő montázs. Montázs, ugyanis a müvészet-meghatározások alapvetően két

${ }^{11}$ D. T. Suzuki: An Introduction to Zen Buddhism. Ed. Christmas Humphreys. Rider \& Company, London, 1979. 61. o.

${ }^{12}$ Uo. 60. o.

13 Laozi: Laozi. LVI. fejezet. In: Kínai filozófia. Ókor / II. kötet. Szöveggyüjtemény. Vál., ford. Tőkei Ferenc. Magiszter Társadalomtudományi Alapítvány, Budapest, 2005. 36. o. Lásd még: Alan W. Watts: A zen útja. Ford. Kepes János. Polgár Kiadó, 1997. 89. o.

${ }^{14}$ A fentebbi összefüggésekhez lásd még: Kőhalmi Péter: A preszókratikától a kvantummechanikáig. In: C3 Gyüjtemény. 2016. április. Interneten: http://www.c3.hu/collection/kohalmi/preszokratika.html; 2016. 04. 21.; Köhalmi Péter: A zen út fokozatai. In: C3 Gyüjtemény. 2016. április. Interneten: http://www.c3.hu/collection/kohalmi/zen.html; 2016. 04. 21.; Kőhalmi Péter: A kreativitás. In: C3 Gyüjtemény. 2016. április. Interneten: http://www.c3.hu/collection/kohalmi/kreativitas.html; 2016. 04. 21. 
esetben kerülhetnek egymást kioltó jelentésviszonyba. Az egyik, ha a különböző művészeti ágak, műfaji, stiláris eszközök, sőt, egymástól lényegileg eltérő művészeti világok egy időben, egymással párhuzamosan élnek. A másik eset viszont ezeknek a totalizáló együvé gyűjtése, akár úgy, hogy a művészet átfogó meghatározásának kísérlete tereli egymás mellé a különböző paradigmák mentén szerveződő, egymástól térben és időben is távol álló elgondolásokat. Az első esetben a jelentéskioltó viszonyhoz még egy feltételnek teljesülnie kell: lennie kell olyan tekintetnek, amely képes ezeket egyszerre látni. A második eset azonban éppen erre épül: a tekintetnek ezen helyét készíti elő a befogadó számára.

Ha pedig a tézisekből kilépünk, azt is láthatjuk, hogy Erdély Miklós szövegkorpuszának egészében a 'jelentéskioltás' fogalma tökéletesen illeszkedik a 'montázs' terminus totalizáló, mindig kiterjeszkedő használatához. Már Erdély 1966-os programadó írását, a Montázs-éhséget ${ }^{15}$ sem tekinthetjük egyetlen területre, a fim médiumára történő fókuszálásnak, s az itt bevezetett 'montázs' terminus bővülő értelmezéséhez hasonló dinamikával bír a ’jelentéskioltás’ fogalma is. Először 1973-ban, a Mozgó jelentés ${ }^{16}$ című írásában a filmek kapcsán jelenik meg, a Marly tézisekben pedig már a mủvészetek egész történetének magyarázóelvévé bővül.

15 Erdély Miklós: Montázs-éhség. In: Valóság. 1966/4. sz. 100-106. o. Újraközölve: Erdély Miklós: Montázs-éhség. In: Erdély Miklós: A filmröl. (Filmelméleti írások, forgatókönyvek, filmtervek, kritikák). Válogatott írások II. (A továbbiakban: AF.) Összeáll. Peternák Miklós. Szerk. Beke László, Szőke Annamária. Balassi Kiadó - BAE Tartóshullám - Intermédia, Budapest, 1995. 95-104. o.

${ }^{16}$ Erdély Miklós: Mozgó jelentés. Zenei szervezés lehetősége a filmben. In: Valóság. 1973/11. sz. 78-86. o. Újraközölve: Erdély Miklós: Mozgó jelentés. (A zenei szervezés lehetősége a filmben). In: AF. 113-126. o. 
A tézisek további értelmezését segítendő érdemes elolvasnunk Morris Weitz néhány gondolatát. Morris Weitz a The Role of Theory in Aesthetics címü írásában a következő kérdést teszi fel: „Lehetséges-e az esztétika elmélete egy valódi definíció, avagy a művészethez szükséges és elégséges tulajdonságok halmaza értelmében?” ${ }^{17}$ A művészet definiálására vonatkozó próbálkozások kudarcait látva arra a következtetésre jut, hogy hiábavaló kísérlet a müvészet lényegének esszencialista megfogalmazása, ugyanis ez semmiképp sem járhat sikerrel. Ezzel együtt, szerinte, ha nem is tudjuk megadni a szükséges és elégséges feltételeit annak, milyen tulajdonságok kíséretében nevezhető valami müalkotásnak, az még nem vonja maga után azt is, hogy ne tudnánk a mindennapokban többnyire érthető módon használni a 'művészet' kifejezést. A 'művészet' szó gyakorlati használhatósága mellett érvelve Wittgensteinre hivatkozik: a Filozófiai vizsgálódásokban kibontott családi hasonlóságok elméletével magyarázza, hogy a közös lényeggel nem leírható müalkotásokat mégis kezelni tudjuk egy szigorúan nem meghatároz(hat)ó fogalommal. ${ }^{18}$ Weitzhez hasonlóan Erdélynél is megjelenik Wittgenstein, nála azonban más előjellel. A Marly tézisek egésze mögött ott húzódik Wittgenstein, azonban nem a 'müvészet' kifejezés gyakorlati használhatóságának zálogaként, hanem a wittgensteini gondolatokat határozott mozdulattal átformálva a nyelvi-logikai korlátokon keletkező hasadás, és az azon való túllépés lehetőségét megalapozandó. Erdély esetében a tautológiák, a nyelvjátékok egymás ellen fordítása, a nyelvjátékok lefordíthatatlansága éppen, hogy a

\footnotetext{
${ }^{17}$ Morris Weitz: The Role of Theory in Aesthetics. In: The Journal of Aesthetics and Art Criticism. 1956. szeptember, 15. évf. 1. sz. 27. o.

${ }^{18}$ Ludwg Wittgenstein: Filozófiai vizsgálódások. Ford. Neumer Katalin. Atlantisz Könyvkiadó, Budapest, 1988. 56-64. o.
} 
nyelv elégtelenségére hívják fel a figyelmet. Számára a cél pedig az ezen való túllendülés. Erdély több helyütt tökéletesen kifordítva idézi Wittgensteint. A Marly tézisek mellé írt jegyzeteiben a következő sorok szerepelnek: „Amiről nem lehet beszélni, arról beszélni kell. Tekinthető a műv[észi] tevékenység a kimondhatatlanról való beszéd stratégiájának."19 Wittgensteinnél ugyanez: „Nyelvem határai világom határait jelentik.”20 Valamint: „Amiről nem lehet beszélni, arról hallgatni kell.” ${ }^{21}$ És a két gondolat, Erdély jelentéskioltása és Wittgenstein hallgatása hogyan tud mégis egymást kibővítve találkozni? Ahogy a Marly tézisekben szerepel: „• A mủalkotás úgy beszél a világ dolgairól, hogy a világ dolgairól való beszéd eltűnik."22

Weitz a válaszkísérletek reménytelenségének okát a müvészet fogalmának logikájában találja meg. Azt állítja, hogy a fogalom logikája teszi lehetetlenné a művészet fogalmának meghatározását: „A müvészet, ahogyan az a fogalom logikájában megmutatkozik, nem rendelkezik szükséges és elégséges tulajdonságok halmazával, ennélfogva egy róla szóló elmélet logikailag lehetetlen, és nem csupán tényszerüen nehézkes. [...] Az esztétika elmélete egy logikailag hiábavaló kísérlet annak meghatározására, amit nem lehet meghatározni, megállapítani annak a szükséges és elégséges tulajdonságait, aminek nincsenek szükséges és

\footnotetext{
${ }^{19}$ Erdély Miklós: [A tézisek mellé...] In: MI. 212. o.

20 Ludwig Wittgenstein: Logikai-filozófiai értekezés. (Tractatus logicophilosophicus). Ford. Márkus György. Akadémiai Kiadó, Budapest, 1989. 70. o. 5.6

${ }^{21}$ Uo. 90. о. 7

${ }^{22}$ Erdély Miklós: Marly tézisek. In: MI. 128. o.
} 
elégséges tulajdonságai, zártként elgondolni a müvészet fogalmát, amikor annak gyakorlatban való alkalmazása nyitottságot fed fel és kíván meg.”23

A tézisekkel ezt összeolvasva azt mondhatjuk, hogy Erdély Miklós nagyon is hasonló belátásból jut egészen más következtetésre. Hiszen ő is úgy határozza meg a müvészet fogalmát, hogy annak nyitottságát meghagyja, viszont pontosan ezt a radikális nyitottságot teszi meg központi elvéül. Ahogy írja: „A tézisekben először teszek kísérletet arra, hogy ezt az ürt [a müvészet fogalmának kiüresedését] nevén nevezzük, ugyanakkor megpróbálom pozitívumnak feltüntetni, ami az űr esetében meglehetősen paradox feladatnak látszik.”24 Vagyis Erdélynél éppen a meghatározhatatlanság hoz létre közös alapot: az üres jelölő intrinzikusan végtelenül nyitott alapját. Teóriájában ráadásul ez a közös elv nem pusztán egyszerü leírásként, hanem lehetőségként is jelentkezik. S hogy minek a lehetőségeként? Babarczy Eszter úgy fogalmaz: „A jelentéskioltás nem a jelentések hiánya, hanem az a hasadás, amely annak nyomán keletkezik, hogy a lehetetlen egész szelíden [...] behatol a világba.”25 És ez az a paradoxonként felismerhető hasadás, melyre Erdély teóriája szerint figyelmünket koncentrálva az addig kezelhetőnek vélt világ, jelen esetben a 'művészet', jelentéseivel együtt kimozdulhat a megszokott keretből.

De ezzel már Morris Weitz egy következő gondolatánál tartunk. Azt írja Weitz, nem úgy kell kérdeznünk, hogy mi x jelentése, hanem inkább úgy, mit csinál x a nyelvben. Az 'x egy müalkotás' kijelentésnek az utóbbi kérdés-javaslat mentén haladva pedig két használatát különíti el. Az

\footnotetext{
${ }^{23}$ Morris Weitz: The Role of Theory in Aesthetics. In: The Journal of Aesthetics and Art Criticism. 1956. szeptember, 15. évf. 1. sz. 28. o., 30. o.

${ }^{24}$ Erdély Miklós: [A tézisek mellé...] In: MI. 219. o.

${ }^{25}$ Babarczy Eszter: Határátlépő. Erdély Miklós. (értelmezési kísérlet). In: Új Müvészet. 1992. április, III. éfv. 4. sz. 7. o.
} 
egyik használat pusztán leíró, deskriptív, formális, osztályozó; míg a másik az erre épülő értékelő, előíró használat. ${ }^{26}$ Könnyen belátható, hogy a művészet fogalmának történetében akkor kerülnek felszínre a legnagyobb dilemmák, amikor nem csupán leíró, de értékelő és egyben akár előíró értelemben is használják azt.

Erdély Miklós tézisei egyáltalán nem választják szét, hanem egyesítik a kétféle használatot: a Marly tézisekben a leírás szorosan együtt jár az értékelő használattal. Mielőtt azonban azt gondolnánk, hogy ez ismét csupán Erdély erős, markáns, már-már konfliktust kereső, kisajátító beszédmódjának példája, meg kell jegyeznünk, hogy a tézisek egyszersmind a leírás objektív érvényességének a lehetőségét is fenntartják. Erdély szerint ugyanis egy kijelentés gesztusa nem feltétlenül önkényes. Egyfelől: „• Hogy mi a művészet, azt megállapítani nem, csak eldönteni lehet.” Másfelől azonban: „• Attól, hogy egy állítás döntés kérdése, nem feltétlenül önkényes.” ${ }^{27}$ Ehhez pedig idézzük Erdély jegyzeteiből azokat a sorokat, melyek szerint a tézisek a müvészet teleológiai folyamának felismerései, ígyhát annak állításai nemhogy önkényesek lennének, hanem egy tudatosulási folyamat fázisaiként olvasandóak: „[...] [M]inden műalkotás - amennyiben megérdemli nevét - mindig is, az idők kezdete óta erre [a jelentéskioltásra] törekedett. Tehát aminek tanúi vagyunk, pusztán egy tudatosulási folyamat, aminek még nem értünk a végére, és remélhetőleg most is jelentős lépéseket teszünk felé.”28

\footnotetext{
${ }^{26}$ Morris Weitz: The Role of Theory in Aesthetics. In: The Journal of Aesthetics and Art Criticism. 1956. szeptember, 15. évf. 1. sz. 30. o., 34. o.

${ }^{27}$ Mindkét idézet forrása: Erdély Miklós: Marly tézisek. In: MI. 125. o.

${ }^{28}$ Erdély Miklós: [A tézisek mellé...] In: MI. 130. o. Erdély több ízben hasonlóan tág perspektívából fogalmaz, így A filmezés késői fiatalságában is: „A valóság önvizsgálatának [...] nem eszköze - fázisa a film.” [Erdély Miklós: A filmezés
} 
késői fiatalsága. (Az underground filmmozgalom kialakulásának társadalmi háttere). In: AF. 183. o.] Nekünk pedig, akik ha nem is a kellőnél nagyobb, de azért kritikai távolságból olvassuk Erdélyt, legalább azt a nem eldönthető kérdést fel kell tennünk, hogy a Marly tézisekre is igazak-e Erdélynek a következő megállapításai: „5. A stílust döntően a művészetek alakítják. A művészek azonban nem képesek a szemléleti ideiglenesség állapotát elviselni és ezért az egyre gyorsabban változó stílusok mindegyikét is mint véglegeset müvelik. 6. Az emberek koruk bódulatában pillanatnyi szemléletüket az egész világegyetemre kivetítik.” [Erdély Miklós: Extrapolációs gyakorlatok. In: MI. 121. o.] 


\section{A Marly tézisek mint költői kiáltvány}

Az előző fejezetben úgy fogalmaztam, hogy a Marly tézisek Erdély Miklós teóriájához tökéletesen illeszkedő montázs. Ezt, mielőtt rátérnék a tézisek utolsó sorainak értelmezésére, még két további meghatározással egészítem ki. Az egyik szerint a Marly tézisek a par excellence konceptuális művészet kiemelkedő példája: konceptuális müalkotás, és ebből a meghatározásból kiemelkedve mégsem konceptuális müalkotás. A másik szerint pedig úgy fogalmazhatunk, hogy a Marly tézisek Erdély Miklós költői kiáltványa - ahol a „költői” bír sajátságos értelemmel. Ez utóbbival kezdem.

Hozzávetőleg a Marly tézisek írásának idején Erdély Miklós a pécsi Városi Müvelődési Központ Ifjúsági Házában hétrészes előadás-sorozatot tartott A 70-es évek müvészete címmel, melyek közül az első a Költői avantgarde címet viselte. Ehhez, valamint a második előadáshoz a Kísérleti Galériában kiállításokat is rendezett az INDIGO csoporttal, melynek egy 1979-es, az egyik kiállítást megbeszélő összejöveteléről hangfelvétel is készült. ${ }^{29}$ Ez az anyag számunkra nem csak azért fontos, mert a kevés közül az egyik dokumentuma az INDIGO csoporton belüli - az alkotások mellett

${ }^{29}$ Az INDIGO csoport 1979. november 7-ei beszélgetéséről, illetve a pécsi előadások időpontjának az Erdély-hagyatékban lévő dokumentumok alapján elvégzett precíz pontosításáról lásd: Szőke Annamária: Erdély Miklós pécsi előadásaihoz kapcsolódó kiállítások: „költészet” és „film” (1979. november és december). In: KREATIVITÁSI GYAKORLATOK, FAFEJ, INDIGO - Erdély Miklós müvészetpedagógiai tevékenysége 1975-1986. (A továbbiakban: KGYFI.) Összeállította Hornyik Sándor, Szőke Annamária. MTA Müvészettörténeti Kutatóintézet - Gondolat Kiadó - 2B Alapítvány - Erdély Miklós Alapítvány, Budapest, 2008. 247-251. o. 
a csoportot nagyon is meghatározó - diskurzusoknak. Hanem azért is, mert Erdély itt elhangzott mondatai szervesen kötődnek esztétikájának jó néhány alapgondolatához, így a montázsra épülő jelentéskioltáshoz is. Erdély korábbi problémafelvetései és egészen aktuális, akár az 1980-as Marly tézisekhez köthető gondolatai is előkerülnek itt újabb összefüggésekbe ágyazva: tömör, profán példákkal kiegészülve, avagy szakrális utalásokkal átszínezve.

Erdély beszélgetésbeli gondolatmenete szerint a költői mint meghatározás az avantgárd alapbeállítottságát jelöli meg. Az avantgárd költői, azaz alapvetően gondolati indíttatású. Eszerint a képzőmüvészetet az általános vélekedéssel szemben nem a képiség, hanem a gondolatiság köti össze a költészettel - akár még a szobrászat esetében is. A költőit azonban még pontosabban olyan műalkotás jelzőjeként használja, amely gondolatiságának a jelentéskioltó tendencia a sajátja: „Ha elég finom a vibrációja egy mủvészeti objektumnak, akkor minden jelentés fokozatosan kiszürődik belőle. Bizonyos enyhe mosolyt szokott ez kiváltani. Ez az enyhe mosoly az, amin keresztül az ember fölfogja azt, hogy ez se ez, se az, se amaz, de valaminek a bejárata. Valami üdeség jelenik meg benne.”30

A jelentéskioltás a fogalmiság felszámolásával készíti elő az utat a költői kilépésre. De honnan is? „Furcsa módon a mosoly mindig egy kilépés, nem tudom, miből... Ezen gondolkozom, hogy miből lépek ki. Nem tudom. Azt is lehet mondani mosolyogva, hogy »volt egy kávé és egy szendvics, az összesen 13.30.« Ezt is lehet mosolyogva mondani, és ebben a pillanatban már kilép valamiből [a pincér], illetve utal arra, hogy miféle

\footnotetext{
${ }^{30}$ Téma: A költészet. Az Indigo csoport beszélgetése az Erdély Miklós Költői avantgarde című pécsi előadásához kapcsolódó kiállításról 1979. november 7-én. In: KGYFI. 273. o.
} 
komolytalan dolgok a számok, egyáltalán a fizetés [...]. Ennek van köze a költészethez.”31 Majd egy kicsivel később: „A pincér mosolya mire vonatkozik? Az egészre. Ettől művészi.”32

Azaz végül is honnan lép ki a pincér? És milyen irányba távozik mosolyogva? Erdély úgy fogalmaz, hiába gondolkodik, nem tudja, miből lép ki. Mondatai azonban nagyon is szervesen kötődnek az újra és újra átgyúrt gondolataihoz: a kávé, a szendvics és a számok, az 13 Ft 30 fillér korrekt szegmentáltsága tökéletesen illeszkedik az analitikus, töredezett beállítottsághoz; míg a pincér egészre vonatkozó, költői mosolya a művész egész-látásához. A beszélgetés egy másik pontján ugyanezen probléma a kávéház profán példája helyett már biblikus reminiszcenciával szerepel. Bori Bálint kérdésére, hogy mi nem vonatkozik az egészre, Erdély válasza: „A rész. A rész szerint való. Sőt, még Pál apostol is így fejezi ki: a rész szerint való látást vesztik el, illetve tükör által homályosan...”33 A néhány hónappal korábbi, szintúgy az INDIGO csoporttal rendezett Müvészkijárat bemutatójukról hasonló konnotációban ír Erdély: „A fehér szín anyagi képviselőjének a tejet választottuk, ami mintegy táplálja gondolkodásunkat, a »teljesség a rész szerint valót.«”34

\footnotetext{
${ }^{31}$ Uo. 256. o.

${ }^{32}$ Uo. 263. o.

${ }^{33}$ Uo.

34 Erdély Miklós: Müvészkijárat (1979. június). In: KGYFI. 240. o. Első megjelenése: In: Indigo. [A csoport 1977-81 közötti kiállításainak a katalógusa.] Szerk. Erdély Dániel, Nemesi Tivadar. Budapest, 1981. 28-29. o. Az utalás mindkét helyen Pál korinthusbeliekhez írott első levelére vonatkozik: „Mert rész szerint van bennünk az ismeret, rész szerint a prófétálás; de mikor eljö a teljesség, a rész szerint való eltöröltetik. [...] [M]ost rész szerint van bennem az ismeret, akkor pedig úgy ismerek majd, amint én is megismertettem.” [13,9-12]
} 
A Marly tézisek költői kiáltvány. Költői, mert a müvészetmeghatározások egymás kioltásán át mégis egybefogják a müvészi tevékenységek végtelen sorát, egészét. Mi több, a deskriptív, formális definiálás lehetetlenségének mosollyal kísért kifordításából az is következik, hogy minden lehet müalkotás, sőt, a minden, az egész a műalkotás. És ahogy, gyorsan tegyük hozzá, a tézisekből az is következik, hogy semmi sem müalkotás - de leginkább a semmi a müalkotás.

Erdély Miklós 1976 januárjára Möbius-kiállítást szervezett a Fiatal Müvészek Klubjába, ahová legyártatott egy Klein-kancsót üvegből. 1979ben, a Textil textil nélkül kiállításhoz kapcsolódva sokszorosításban is megjelent az Új jin-jang jel című tusrajza, mely szerint az új jel „két Kleinféle kancsó egyesítése révén létrehozható javasolt jel”. Ekkor állította ki a Möbius-sarkot is, a Möbius-szalag egy rajzolt, vágott, hajtogatott, zavarba ejtő variánsát. ${ }^{35} \mathrm{Az}$ egy évvel később, 1980-ban felolvasott Marly tézisek pedig pontosan olyan, mint egy Klein-féle kancsó megtöltése. A Felix Christian Kleinról elnevezett kancsó ugyanis olyan önmagába forduló

Erdély mondatait, miszerint nem tudja, miből történik a kilépés, érthetjük úgy is - ahogy majd erre még kitérek -, hogy csak a kilépés hová-ja igazán meghatározható. Sőt, akár úgy is, hogy csak a kint biztos tere felől meghatározható a bent folyamatosan változó képlékenysége: „[...] [M]ilyen őrült szüksége van az embernek az állandó megújulásra, a kilépésre. És az örök érvényes dolog irányába tud kilépni.” [Téma: A költészet. Az Indigo csoport beszélgetése az Erdély Miklós Költői avantgarde címü pécsi előadásához kapcsolódó kiállításról 1979. november 7-én. In: KGYFI. 275. o.]

${ }^{35}$ Az említett munkákhoz lásd: Szőke Annamária: „Titok a jövő jelenléte”. Tudomány a müvészet határain belül Erdély Miklós mủvészetében. In: Né/ma? Tanulmányok a magyar neoavantgárd köréböl. Szerk. Deréky Pál és Müllner András. Ráció Kiadó, Budapest, 2004. 259-260. o.; Beke László: Erdély Miklós munkássága. Krono-logikai vázlat képekkel 1985-ig. In: Erdély Miklós. Kiállítási katalógus, Óbuda Galéria, Zichy Kastély, 1986. április 11. - május 5. 15. o. 
felület, melynek csak egyetlen oldala van: nincsen külső és belső felülete, nincsen a külsőt és a belsőt elválasztó határa, a külseje egyszersmind a belseje is. A kancsó két Möbius-szalag egymáshoz illesztésével állítható elő. Erdély hasonlatával: „[...] [H]a az elefánt az ormányát a szájába veszi, topológiailag Klein-féle kancsónak tekinthető."36 A tézisek alapján tehát a müvészet fogalmának meghatározása olyan, mint egy Klein-féle kancsó mosollyal kísért megtöltése. A mủvészet egyfelől az, ami a kancsóban van, viszont, mivel a kancsó belső fala nem megkülönböztethető a külsőtől, minden a kancsóban van, ezért minden művészet. Fordítva ellenben: ha az nem müvészet, ami a kancsón kívül van, akkor, mivel a kancsónak csak külső felülete van, semmi sincs, ami belül lehetne, azaz csakis a semmi lehet müvészet.

A Marly téziseket könnyüszerrel olvashatjuk a müvészetről szóló megállapítások inkoherens sorozataként: olyan tézissorként, melyben még a logika legalapvetőbb szabályai, az ellentmondás-mentesség és a kizárt harmadik törvénye sem érvényesülnek. Olvashatjuk a téziseket a körülötte kibomló diskurzust meghatározó értelmezőket, Kibédi Varga Áront és Petőfi S. Jánost követve, rész szerint látva, aporiákat előszámolva benne,

\footnotetext{
${ }^{36}$ Az idézet a Möbius-kiállítás sokszorosított felhívásából származik. Ennek egy másik részlete: „Möbius-bemutatót azért rendezünk, hogy felhívjuk a figyelmet a tiszta gondolat esztétikai értékeire és nem utolsósorban azért, hogy megvédjük attól az agresszív szemlélettől, amit Max Born naiv realizmusnak nevez. Ez a szemlélet a gondolkodást szívesen bélyegzi spekulációnak és éppen az egyszerüség nevében igyekszik megfojtani. A közvetlen tapasztalattól távol álló, nem megszokott szellemi mozdulatokat - melyeknek a Möbius-szalag modellje lehet - elutasítja, a józan (paraszti) észre hivatkozik. A tiszta gondolatot elvontnak nevezi, hogy elvonja másoktól és önmagától is azt a képességet, ami bennünk a legemberibb.” [Erdély Miklós: A Möbius-bemutatóhoz. Sokszorosított felhívás, 1975.]
} 
szemantikai-szintaktikai anomáliákat letapogatva - sőt, ahogy ők is teszik, egy párhuzamos, ellentmondásoktól és „terminológiai pontatlanságtól” mentes tézissor-javaslatot is összeállítva -, ráadásul egyszerü münemi meghatározással vélhetjük úgy, hogy a Marly tézisek nem vers, hanem próza. Vagy olvashatjuk és kezelhetjük versként. A két megközelítés közötti lényegi különbség pedig természetesen nem a münemi meghatározások közkeletü különbsége. De nem is csupán az, hogy téziseket a müvészetről szóló szövegként vagy egyszersmind müalkotásként kezeljük. Az alapvető különbség a paradoxikusság másirányú megközelítésében rejlik. Abban, hogy a Marly tézisekben sürüsödő paradoxikusságot hibaként, tévedésként, kiküszöbölendő anomáliaként látjuk, mellyel találkozva mind erősebben kapaszkodunk bele jól bejáratott kategóriáinkba és nyelvi-logikai sémáinkba, vagy akként, amely kibillentő hatásával képes lehet felhívni a figyelmet a megismerést korlátozó megszokásokra, s a már ismertet kimozdítva rögzült kereteiből talán képes utat nyitni az újra, a még ismeretlenre: akár a töredezettség, a fragmentáltság mosollyal kísért kifordításán át megnyíló egészre. ${ }^{37}$

\footnotetext{
${ }^{37}$ Marly-le-Roi-ban a tézisek felkért vitapartnere, Horányi Özséb nem tudott jelen lenni, pedig az ő „fogai számára” hagyott benne helyet Erdély. Kibédi Varga Áron és Petőfi S. János itt elhangzott hozzászólásainak tanulmány formára bővített variánsait a Magyar Mühely közölte. Kibédi Varga Áron a tézisek szóhasználatának vizsgálatával indítja megjegyzéseit: a használt terminusok pontatlanságában véli felfedezni az inkoherencia forrását, melyet elkerülendő részben új terminológia bevezetését javasolja, ám ezzel együtt merőben más, a Marly tézisektől alapvetően eltérő megállapításokat javasol az üresség és a müalkotás viszonyát, valamint ezek befogadását illetően. Petőfi S. János tanulmánya két nagyobb egységből áll. Elöbb a 'szöveg', 'jelentés' és 'interpretáció' különböző megközelítéseit sorra véve bevezeti saját terminológiáját, majd Erdély téziseit elemzi három alfejezetre osztva: a leíró interpretációt értelmező interpretáció, majd értékelő interpretáció követi. A leíró
} 
interpretáció során, ahogy írja, „megpróbál” a tézisekhez egy számára „elfogadható koherens jelentést” rendelni, Erdély téziseivel párhuzamosan egy újabb, kvázi ellentézissor-javaslatot összeállítva, és azt kommentárokkal ellátva. Rámutat a terminusok „félrevezető használatára” - vagy épp csak három kérdőjelet kitéve a tézisek értelmezhetetlenségére -, ám főként a tézisekben feszülő ellentmondásokra: a különböző tézisek egymással összeegyeztethetetlen voltára, de akár egyetlen tézisen belüli ellentmondásra, s arra, hogy az 'üres jel' már önmagában véve is ellentmondás, contradictio in adjecto. Az értelmezö interpretációban különböző magyarázatokat fogalmaz meg arról, hogy miért térhet el egymástól a két tézissor, Erdélyé és az általa javasolt. Az eltéréseket többek közt a következőkkel magyarázza: „Erdély azt hitte, hogy a racionális argumentáció logikája szerint fogalmazza meg téziseit, de nem volt ideje azokat annyi ideig nyugodni hagyni, amennyi elegendő lett volna ahhoz, hogy kellőképpen eltávolodva tőlük, észrevette volna, hogy azok rendszere nem tökéletes." Valamint: „Erdély azt hitte, hogy a racionális argumentáció logikája szerint fogalmazta meg téziseit, és nem vette észre (esetleges eltávolodása ellenére sem), hogy fogalmazása nem tökéletes.” Ám megemlíti a következő lehetőséget is: „Erdély eredetileg a racionális argumentáció logikája szerint fogalmazta meg téziseit, azokat azonban több helyen kisarkította, hogy meghökkentsen, mert ettől nagyobb hatást (jobb eredményt) várt, mint a racionális argumentációtól.” Azonban tanulmányát végül a következőkkel zárja: „Nem kételkedem abban, hogy Erdély művészetről alkotott gondolatai fogalmilag összefüggő rendszert alkotnak, nem hiszem azonban, hogy téziseihez rendelhető olyan interpretáció, amelynek alapján adott formájában mint összefüggő rendszer elfogadható lenne. Akár félreértettem Erdélyt, akár nem, hiszem, hogy az általam megfogalmazott tézis-rendszer fogalmilag és nyelvileg konzisztens, azt is hiszem, hogy mint müvészetről alkotott egyik lehetséges felfogás elfogadható." [Kibédi Varga Áron: Megjegyzések Erdély Miklós Téziseihez. In: Magyar Mühely. 1981. július, XIX. évf. 64. sz. 34-35. o.; Petőfi S. János: Szöveg és jelentés. In: Magyar Mühely. 1981. július, XIX. évf. 64. sz. 36-59. o. Az idézetek forrása: I.m. 47. o., 53. o., 55. o., 57. o., 58. o., 59. o. A tézisekhez lásd még a következőket: Hegyi Lóránd: Az antimüvészet pályái és Erdély Miklós helyzete. In: Magyar Mühely. 1983. július, XXI. évf. 67. sz. 11-20. o.; Peternák Miklós: A konceptuális müvészet hatása Magyarországon. 1983-85. Interneten: http://www.c3.hu/collection/koncept/help.html; 2012. 11. 23.; Peternák Miklós: concept.hu | koncept.hu. A konceptuális müvészet hatása Magyarországon. The Influence of Conceptual Art in Hungary. Paksi Képtár - C3 Alapítvány, 2014. 5861. o.; Nagy Pál: Párhuzamos életrajzok. Robert Filliou, Erdély Miklós. In: 
Még mindig a költői kiáltvány meghatározásnál maradva, a téziseket abban a sajátságos meghatározásban is vélhetjük költőinek, ahogy Erdély a Metán címü versében öndialogizálva írja: „- A versíráshoz nélkülözhetetlen egy olyan belső mosoly, ami elég huncut és rezignált is egyszerre, de van átható tekintete is.”38 Vagy persze úgy, ahogy szintén a Metán című poéma egymásból merítkező, egymást író sorai szólnak:

- Bárki kétségbe vonhatja, hogy amit most olvas, az vers, hiszen a szövegben teljes mértékben prózai viszonyok uralkodnak. Mégis költőinek kell neveznem ezt a törekvést két okból: másodszor, mert az az elhatározás, hogy verset írok, a felelösségérzetet írás közben felfokozza. Hogy először miért, azt elfelejtettem, de később - bizonyos vagyok benne - eszembe fog jutni.

[...]

- Az okfejtés már nemcsak derék és nevetséges, hanem jószerivel zavaros is.

[...]

- Tehát attól vers a vers, hogy nem törekszik ellentmondás-mentességre.

Magyar Napló. 1991. november 29. III. évf. 16. sz. 32-33. o.; Forgács Éva: A neoavantgárd magánya. Erdély Miklós: Mủvészeti írások. (Válogatott müvészetelméleti tanulmányok). In: Új Müvészet. 1992. április, III. éfv. 4. sz. 8182. o.; Nagy Pál: Erdély Miklós: Tézisek az 1980-as marly-i konferenciához. In: Magyar Mühely. 1999. XXXVII. évf. 110-111. sz. 17-23. o.; Brendel János: Signum temporis. Megjegyzések Erdély Miklós müvészeti írásaihoz. In: Magyar Mühely. 1999. XXXVII. évf. 110-111. sz. 24-28. o.; Bujdosó Alpár: A semmi, az üres jel, a polivalencia és a nyílt tér. In: Magyar Mühely. 1999. XXXVII. évf. 110-111. sz. 69-74. o.; Ungváry Rudolf: A személyes müvész. Erdély Miklós nem triviális helye a struktúrában, avagy A találékonyságba belekapaszkodó ember. In: Magyar Mühely. 1999. XXXVII. évf. 110-111. sz. 176-188. o. Újraközölve: In: Kritika. 1999/2. sz. 34-36. o.

${ }^{38}$ Erdély Miklós: Metán. In: Erdély Miklós: Második kötet. (A továbbiakban: MK.) Vál., szerk. Beke László, Peternák Miklós és a Magyar Mühely szerkesztősége. Magyar Mühely, Párizs, Bécs, Budapest, 1991. 8. o. 
- Attól még nem lesz valami valami, hogy valamilyen nem.

- Azonban ez nem valamilyen, hanem igenis zavaros. Attól a prózából nem lesz vers, hogy zavaros.

- De igenis, mert ha jókor zavaros, akkor a vers próza.

$[\ldots]$

- [...] ha a vers demokratizmusa müködésbe lép, és más összefüggésben lépteti fel a megláncoltakat, a szabadság fuvallatát érezzük. ${ }^{39}$

39 Erdély Miklós: Metán. In: MK. 9-11. o. Földényi F. László nagyszerü tanulmányának következő sorait, habár nem a Marly tézisek a tárgyuk, mégis olvashatjuk úgy, mint amelyek Erdély téziseire is vonatkoznak: „Erdély költői munkásságát olvasva olyan benyomásom alakult ki, hogy vonzza őt a botladozás, az ellentmondás, szeret belegabalyodni a saját lábába, és örömét leli abban, ha a leírt szavak és a papírra vetett gondolatok egymást hazudtolják és cáfolják. [...] [V]onzza őt, ha mindarról, ami megfogalmazható, leírható vagy kimondható, bebizonyítja, hogy az így, ebben a formájában vagy változatában korántsem nyerte el a maga végleges formáját.” [Földényi F. László: „....saját lábába botlik...” Erdély Miklós és az irodalom. In: Magyar Mühely. 1999. XXXVII. évf. 110-111. sz. 33. o. Újraközölve: In: Né/ma? Tanulmányok a magyar neoavantgárd köréböl. Szerk. Deréky Pál és Müllner András. Ráció Kiadó, Budapest, 2004. 73. o.] Egy ön-párbeszéd létrejöttének az esélyéről pedig lásd Sugár János sorait: „Létezik nézőpont, melyből még a visszhang is egyenrangú partner, ami azt jelenti, hogy már a hangsebesség okozta késés is elegendő lehet, hogy ugyanaz esetleg inspirálóan hasson vissza.” [Sugár János: Ahonnan minden egyfele van. In: Mínusz pátosz. Balassi Kiadó - Intermedia, Budapest, 1995. 18. o. A szöveg korábbi variánsa: Sugár János: Mínusz pátosz. In: Hasbeszélö a gondolában. A Tartóshullám antológiája. (Jóvilág 3.). (Cápa 4.). Szerk. Beke László, Csanády Dániel, Szőke Annamária. Bölcsész Index, Budapest, 1987. 285288. o. Ezúton is köszönöm Sugár János segítségét.] 


\section{A Marly tézisek mint (nem) konceptuális műalkotás}

A Marly téziseket tekinthetjük montázsnak, költői kiáltványnak, s ezeken túl, még egy meghatározással élve, a par excellence konceptuális művészet kiemelkedő példájának: konceptuális müalkotásnak, és ebből a meghatározásból kiemelkedve mégsem konceptuális műalkotásnak.

Magyarországon a '60-as évek második felében kezdtek felerősödni a konceptualizmus első impulzusai, majd csakhamar, már a ’70es évek elejére az avantgárd egyik meghatározó irányzatává nőtte ki magát. Ez az időszak egybeesik Erdély Miklós színrelépésének és növekvő befolyásának éveivel. Ekkortól vált fokozatosan a korszak legjelentősebb mesterévé, tanítványokat maga köré gyüjtő apafigurájává, az avantgárd konzekvensen új utakat kereső szabad alkotójává. Szinte az első megjelenésétől, 1966-tól kezdve megkerülhetetlenné tették őt gondolkodásra késztető artefactumai, vibráló, eredeti, szokatlan szemlélete és markáns habitusa. A konceptuális müvészet szűkre szabott felfogásaitól már a ’70-es évek derekától elhatárolta magát, azonban a sürü gondolati indíttatás és az interdiszciplináris magatartás újabb és újabb utakon, de mindvégig sajátja maradt élet(müv)ének.

A honi elméleti szakma ekkor, ahogy Erdély is, a konceptualizmusról, a konceptről, a concept artról és a conceptual artról, az ötletművészetről, a fogalomművészetről és a fogalmi müvészetről beszélve többnyire Joseph Kosuth szükebben vett, analitikus konceptual artértelmezését és munkáit tartotta mérvadónak. Azt a nyelvi központú felfogást, amit analitikus művészetnek vagy akár tautologikus 
konceptualizmusnak is nevezhetünk. ${ }^{40}$ Kicsit közelebbről: Joseph Kosuth Wittgensteinre, valamint a neokantiánus A. J. Ayer Kant-interpretációjára

${ }^{40}$ Magyarországon Beke László tekintette át először a „Concept Art” honi és külföldi megjelenési formáit: az 1972-ben publikált cikkeiben a fotóhasználat egészen friss fejleményeit követve számol be a concept artról. Feltehetően Beke László úttörőnek számító írásainak köszönhető, hogy Magyarországon leginkább a Henry Flynt-féle concept art elnevezés terjedt el, ahogy az is, hogy a conceptjelzővel Beke nyomán a honi szakma többsége valójában a Kosuth-féle conceptual art felfogást jelöli meg. Ugyancsak 1972-ben már Rózsa Gyula is beszámol a nehezen megközelíthető, újkeletü „fogalmi müvészetről” a 750 ezres példányszámot is elérő Népszabadság hasábjain: „A fogalmi művészetet külföldön kitalálták, és nálunk is művelni kezdték, nem tehetünk mást, mint létezését tudomásul véve - megpróbáljuk értékelni." A honi mezőnyből Rózsa végül mindössze egyetlen példát említ - Erdély A hó fekete címü akció-munkáját, melyet Beke nyomán ismer -, majd megnyugtatásul megjegyzi: „Józan fővel senki sem gondolhatja, hogy képzőmüvészetünket tönkreteszi a »fogalmi müvészet« [...]. Nem emészti fel nyugaton sem, ahol pedig sokkal nagyobb reklámmal tör elöre." Beke László cikkei után a recepció következő fontos lépcsőfoka Hajdu István 1975-ben és 1976-ban, három részletben közölt tanulmánya. Hajdu már szembesíti egymással a konceptuális- és a koncept müvészet különböző teóriáit, több síkon bemutatva a Joseph Kosuth és Sol LeWitt elképzelései mentén kialakult szemléletbeli különbségeket. 1983-ból, Peternák Miklós tollából származik az első igazán nagy, összegző igényű munka - melyet sajnos csak jóval később ismerhetett meg a szélesebb publikum, ugyanis egészen a '90-es évekig a szerző asztalának fiókjában maradt. (Előbb interneten, majd bő 30 évvel a megírása után, 2014-ben, ekkor már két nyelven, könyv formában is nyilvánosságot kapott.) Peternák Miklós könyve föként a magyar törekvéseket öleli át, több szempont mentén sorra véve a magyar jelenségek addig többségében feltérképezetlen vonulatait. Írása azonban áttekinti a teória nemzetközi tendenciáit is: rámutat a terminus-szerü értelmezések önmagukba és egymásba gabalyodására, az elméleti tisztázás elvi lehetetlenségére. Az összekuszálódott teóriák magyarításának és honi kibogozásának szinte reménytelen vállalkozására jó példa könyvének polemikus felvezetése: „Nem új megállapítás, hogy szigorú értelemben nem volt konceptuális mủvészet Magyarországon, és helytállónak tűnik. Ugyanígy igaz, hogy beszélhetünk egy nagyarányú "koncept" (ötlet) - 
müvészetről. $\mathrm{Az}$ az állítás sem támadható, hogy a "concept-art" (fogalommủvészet) vagy "conceptual art" (fogalmi művészet) névvel jelölt irányzatnak jelentős hatása volt a magyar (avatgarde) müvészetre, sőt a müvészeti (illetve múvészetről való) gondolkodásra általában. [...] Felmerülhet, miért van szükség ilyen körülmények között egyáltalán a szóra (a »koncept « fogalmára, vagy - világosabban - a »fogalom fogalmára«), s ezen túl, ha már használom, miért zárkózom el a definíciótól eleve. Az okok: Véleményem szerint a konceptuális múvészetről nem lehet írni, hiszen egyik alap-megállapítása, hogy a kritikus vagy interpretátor szerepét és személyét szükségtelennek tartja. Tekinthetem így az írást koncept mủvészetnek (s akkor - mivel »az« nem »arról« szól) vagy figyelmen kívül hagyva írhatok róla mégis - s akkor ugyancsak nem lesz sok köze a koncept arthoz, hiszen egyik alapsajátosságát hagyom figyelmen kívül. Lehet viszont elemezni egyfajta müvészi tevékenység és gondolkodásmód hatását, melyet általában a konceptuális jelző segítségével neveznek meg, mely szókapcsolat átment a köztudatba, s - mert használatos - feltehetően használható is, és meglehetős pontossággal jellemzi - különbözteti meg tárgyát.” És az idetartozó lábjegyzet: „Az, hogy a concept artról nem lehet írni, végső soron annyit jelent, hogy csak a »concept art « terminus használatának a hogyanjáról nem lehet írni (másképp: pont azt, hogy nem definiálható). Ha ugyanis igaz, hogy a jelentés a használatban van, akkor a concept art nem más, mint a mủvészetfogalom múvészi kontextusbeli használata, tehát maga a művészetfogalom. Így legföljebb azt írhatom: a concept art az a concept art (vagy a concept art nem a concept art) - az irányzat jellegének megfelelően definíció helyett tautológiához jutok. Ennyit mondhatok: javaslom, hogy használjuk (a kifejezést), vagy: használni fogom.” [Beke László: Miért használ fotókat az A.P.L.C.? In: Fotóművészet. 1972/2. sz. 20-26. o. Újraközölve: In: Uő: MÉDIUM/ELMÉLET Tanulmányok 1972-1992. Balassi Kiadó - BAE Tartóshullám - Intermedia, Budapest, 1997. 7-16. o.; Beke László: Fotó-látás, fotóhasználat az új magyar művészetben. In: Fotómüvészet. 1972/3. sz. 18-24. o. Újraközölve: In: Uö: MÉDIUM/ELMÉLET Tanulmányok 1972-1992. Balassi Kiadó - BAE Tartóshullám - Intermedia, Budapest, 1997. 17-27. o.; Hajdu István: Concept Art. Kísérlet egy műfajtalan műfaj rendszerezésére. In: Tájékoztató. Magyar Képzőmüvészek Szövetsége, 1975/4. sz., 1976/1. sz., 1976/2. sz. Interneten: http://www.c3.hu/collection/koncept/help.html; 2012. 11. 23. Az idézetek forrása: Rózsa Gyula: A valóság nem válaszol. Kasseli és budapesti jegyzetek a művészetről. In: Népszabadság. 1972. november 19. Vasárnapi melléklet. 7. o. 
alapozva a müalkotást analitikus javaslatnak tekinti, mely magyarázatát nem a külvilág tényeiből nyeri, hanem önmagában hordozza. A művészet kijelentései Kosuth szerint nyelviek.

A Marly téziseket a kosuthi törekvések alapján feltétlenül mủalkotásnak kell tekintenünk, sőt, a honi konceptuális müvészet első nagy lendületét összegző csúcsteljesítménynek. A téziseket, ahogy Kosuth látásmódját is, az analitikus, nyelvi központú szemlélet alapozza meg.

Egy részletét idézi: Szabó Júlia: Idézetek a hetvenes évek müvészetének irodalmából. In: Müvészet. 1980. október, XXI. évf. 10. sz. 17. o.; Peternák Miklós: A konceptuális müvészet hatása Magyarországon. 1983-85. Interneten: http://www.c3.hu/collection/koncept/help.html; 2012. 11. 23.; Peternák Miklós: concept.hu | koncept.hu. A konceptuális müvészet hatása Magyarországon. The Influence of Conceptual Art in Hungary. Paksi Képtár - C3 Alapítvány, 2014. 1112. o. A konceptuális művészet honi recepciótörténetéről, a fogalomhasználat és a korszakolás nehézségeiről az 1990-es, majd a 2000-es évekből visszatekintve lásd: Andrási Gábor: A gondolat formái. In: Nappali ház. 1993/2. sz. 70-77. o. Újraközölve: A gondolat formái. „Érzéki konceptualitás« a kortárs magyar képzőmüvészetben. In: A modern poszt-jai. Esszék, tanulmányok, dokumentumok a 80-as évek magyar képzömüvészetéröl. Szerk. Keserü Katalin. ELTE, Bölcsészettudományi Kar, Budapest, 1994. 75-87. o.; Hornyik Sándor: Konceptualizmus a kilencvenes évek magyar képzőmüvészetében. In: Müvészettörténeti Értesitó. 2002/3-4. sz. 251-264. o.; Tatai Erzsébet: Neokonceptuális mủvészet Magyarországon. In: [CONCEPTUAL ART AT THE TURN OF MILLENIUM]. [KONCEPTUÁLNE UMENIE NA ZLOME TISÍCROČÍ]. [KONCEPTUÁLIS MÜVÉSZET AZ EZREDFORDULÓN]. AICA Section Hungary, Slovak Section of AICA, Budapest, Bratislava, 2002. 115-141. o.; Tatai Erzsébet: Hordozható Múzeum. A pop-art, konceptuális művészet, akcionalizmus Magyarországon a 60-as években. In: Új Müvészet. 2003/12. sz. 22-23. o.; Tatai Erzsébet: Neokonceptuális müvészet Magyarországon a kilencvenes években. Præsens, Budapest, 2005.; Székely Katalin: A valóság válaszol. Koncept koncepció, szemelvények. In: Balkon. 2008/6. sz. 2-3. o.; Tatai Erzsébet: Láthatatlan müvek kiállítása. Koncept koncepció, szemelvények. In: Balkon. 2008/6. sz. 4-6. o.; András Sándor: Koncept? Ötlet? Hol és kinek? Koncept koncepció, szemelvények. In: Balkon. 2008/6. sz. 6-9. o.] 
Erdély azonban vérbeli gondolkodóként - egészen kivételes módon - a konceptuális müvészet Kosuth-féle meghatározásából kifelé tekint. S teóriájában a nyelvi-logikai térből való paradoxikus kilépések adják a lehetőségét annak, hogy a müalkotást az analitikus szemléleten túllendülve végül mégis az igazság, a szépség és a szabadság új erőre kapó, klasszikus, kontinentális fogalmaival határozza meg.

Erdély Miklós esetében megalapozottan kerülhetnek elö Kosuth gondolatai: „Minden egyes művészetről szóló szöveg mögött ott van a müalkotás lehetösége vagy annak jelenléte. [...] A müvészetröl való beszéd párhuzamos cselekvés a művészet csinálásával [...]." ${ }^{41}$ Kosuth szerint a

${ }^{41}$ Joseph Kosuth: The Play of the Unsayable: A Preface and Ten Remarks on Art and Wittgenstein. In: Joseph Kosuth: Art after Philosophy and After - Collected Writings, 1966-1990. Ed. Gabriele Guerico. The MIT Press, Cambridge, Massachusetts, London, England, 1991. 248-249. o. Erdélyről és a konceptuális müvészetről lásd még föként a következőket: Beke László: Türni, tiltani, támogatni. A hetvenes évek avantgárdja. In: A második nyilvánosság - XX. századi magyar müvészet. Összeállította Hans Knoll. Enciklopédia Kiadó, Budapest, 2002. 229-247. o.; Beszélgetés Beke Lászlóval. In: Hatvanas évek. Új törekvések a magyar képzömüvészetben. Kiállítási katalógus, Magyar Nemzeti Galéria, 1991. március 14. - június 30. Összeáll. Beke László, Dévényi István, Horváth György. Szerk. Nagy Ildikó. Képzőművészeti Kiadó - Magyar Nemzeti Galéria - Ludwig Múzeum, Budapest, 1991. 193-197. o.; Beke László: A magyar konceptuális müvészet szubjektív története. In: Né/ma? Tanulmányok a magyar neoavantgárd köréböl. Szerk. Deréky Pál és Müllner András. Ráció Kiadó, Budapest, 2004. 227-239. o.; Beke László: Műfajok és médiumok. In: Uő: MÉDIUM/ELMÉLET - Tanulmányok 1972-1992. Balassi Kiadó - BAE Tartóshullám - Intermedia, Budapest, 1997. 102-119. o.; Beke László: Kontextuális művészet. In: Uő: MÜVÉSZET/ELMÉLET - Tanulmányok 19701991. Balassi Kiadó - BAE Tartóshullám - Intermedia, Budapest, 1994. 152-154. o. Beke László: Képzőművészet 2000-ben? In: Uo. 56-68. o.; Beke László: Újabb avantgarde irányzatok. In: Uo. 119-126. o.; Beke László: Conceptual Tendencies in Eastern European Art. In: Global Conceptualism: Points of Origin 1950s- 
műalkotás nem csupán megfeleltethető a művészetről szóló szövegnek, hanem egyszersmind javaslettétel is, mely a müvészet lényegére vonatkozik: „A müvészek akkor kérdeznek rá a művészet lényegére, amikor új javaslatokat tesznek a művészet lényegére vonatkozóan. [...] [B]elátható, hogy egy mủalkotás nem más, mint egyfajta javaslat, mely a mủvészeti összefüggésben a müvészet kommentárjaként jelenik meg [...]." ${ }^{42}$ Számára a művészet célja a művészet funkciójának fogalmi úton történő megváltoztatása. Erdély pedig ezzel nagyon is egybevágó dolgokat ír a tézisek előszavában, $A$ müvészet mint üres jelben: „[...] [Sz]inte naponta kell a müvésznek önmagát kérdőre vonnia, hogy tulajdonképpen mit is müvel. [...] A mai müvésznek el kell viselnie, hogy hivatása metaszinten problematikussá vált, és müveiben erre reflektálnia kell. [...] [A] létrejött müvek tekinthetők úgy, mint elfogulatlan javaslatok a művészet jövőbeli hivatására."43 Kosuth és Erdély mondatai tökéletes

1980s. Ed. Luis Camnitzer, Jane Farver, Rachel Weiss. Queens Museum of Art, New York, Walker Art Center, Minneapolis, Miami Art Museum, Miami, 1999. 41-51. o. Valamint lásd Körner Éva írását, mely Joseph Kosuthnak a XLV. Velencei Biennále magyar pavilonjában rendezett kiállítása apropóján tekinti át a honi konceptualizmust: Körner Éva: Az abszurd mint koncepció - A magyar konceptualizmus jelenségei. The Absurd as Concept - Phenomena of Hungarian Conceptualism. L'assurdo come concezione - I fenomeni del concettualismo ungherese. In: Kosuth, Joseph: 'Zeno Az Ismert Világ Határán'. 'Zeno At The Edge Of The Known World'. 'Zeno All'Orlo Del Mondo Conosciuto'. Kiállítási katalógus, Velencei Biennále, XLV Nemzetközi Müvészeti Kiállítás, Magyar Pavilon, 1993. 185-198. o., 208-219. o. A tanulmány két részletben közölt variánsa: Körner Éva: Az abszurd mint koncepció. Jelenetek a magyar koncept art történetéből. I. rész. In: Balkon. 1993/1. sz. 22-25. o.; Körner Éva: Az abszurd mint koncepció. Jelenetek a magyar koncept art történetéből. II. rész. In: Balkon. 1993/2. sz. 10-18. o.

${ }^{42}$ Joseph Kosuth: Art after Philosophy. In: Uo. 18. o., 20. o.

${ }^{43}$ Erdély Miklós: A művészet mint üres jel. In: MI. 124. o. 
összhangban vannak. Főként, ha azt is hozzáolvassuk, hogy Erdély nem egyszerủen a mủvészet fogalmának teleologikus kiüresedését detektálja, és nem is csupán a kiüresedés folyamatában vállalt szerepük alapján tesz javaslatot a műalkotások értékelésére. Az értékelést mintegy rövidre zárva, az egyedi műalkotás feladataként is a mủvészet-fogalom dinamikájának megjelenítését tűzi ki célul. Jegyzeteiben ez úgy szerepel: „Ha a müvészet üres fogalom, természetesen a mủalkotás se tehet mást, mint igyekszik üresnek maradni.”44 A Marly tézisekben pedig: „A műalkotás tehát olyan jelnek tekinthető, mely a különböző jelentéseket egymás rovására erősíti föl, szaporítja, ezeket egymás által kioltja, így a müalkotást, mint egészet megfosztja attól a lehetőségtől, hogy jelentéssel bírjon." 45 A Marly tézisek ennek alapján a par excellence konceptuális müvészet izzó, briliáns darabja.

Ugyanakkor, ha Erdély törekvéseit, egymásnak ütköző gondolatait egy térbe is helyezhetjük a konceptuális mủvészet Kosuth-féle teóriájával ahogy egyébiránt Erdély is többször utal erre -, a kettejük közti különbségek már csak a Marly tézisek alapján is felsejlenek. Erdély elméletében ugyanis a műalkotás befogadása várhatóan más irányba tart, mint a konceptuális müvészet esetében. Beke László tolmácsolásában: „A Concept Art úgy akarja a müvészet funkcióját megváltoztatni, hogy a valóság értelmezése helyett a müvészet, vagyis önmaga értelmezését tekinti céljának."46 És igen, Kosuth a neokantiánus A. J. Ayer Kantinterpretációja, illetve Wittgenstein nyomán a müalkotást analitikus

\footnotetext{
${ }^{44}$ Erdély Miklós: [A tézisek mellé...]. In: MI. 129. o.

${ }^{45}$ Erdély Miklós: Marly tézisek. In: MI. 127. o.

${ }^{46}$ Beke László: Miért használ fotókat az A.P.L.C.? In: Uő: MÉDIUM/ELMÉLET Tanulmányok 1972-1992. Balassi Kiadó - BAE Tartóshullám - Intermedia, Budapest, 1997. 14. o.
} 
javaslatnak tekinti. A szintetikustól elkülönítve az analitikus javaslat ebben az értelmezésben olyan, melynek érvényessége egyedül önmagára vonatkozik, s magyarázatát sem a külvilágból nyeri, hanem önmagában hordozza. A művészet kijelentései nyelviek. Kosuth szerint „a műalkotások [...] semmiféle információt nem közölnek semmiféle tényröl. [...] [A] müvészet kijelentései lényegük szerint nem tényekre vonatkoztatottak, hanem nyelviek [...].”47 Lyotard erről a következőképpen fogalmaz: „Kosuth munkája meditáció az írásról. [...] Az írott mondat sosem transzparens, mint az ablaküveg, vagy pontos, mint a tükör.”48 Erdély Miklós tézisei viszont éppen, hogy az átléphetetlennek vélt határok megnyitásáról, így a wittgensteini lehetetlen elérésnek a lehetőségéről is szólnak. Idézzük ismét a tézisek utolsó pontját: „• A müalkotás úgy beszél a világ dolgairól, hogy a világ dolgairól való beszéd eltűnik." "49

Azt hiszem, az itt felfeslő különbségek mélyebb hátterére is utalnom kell. Erdélynek a tézisekhez írt jegyzeteiben szerepel a következő,

${ }^{47}$ Joseph Kosuth: Art after Philosophy. In: Joseph Kosuth: Art after Philosophy and After - Collected Writings, 1966-1990. Ed. Gabriele Guerico. The MIT Press, Cambridge, Massachusetts, London, England, 1991. 17. o.

48 Jean-François Lyotard: Foreword: After the Words. In: Uo. XV-XVI. o. Lyotard egy hosszabb gondolatmenete pedig úgy szól: „Kosuth vizuális munkáit a Tóra szögletes betüivel hasonlítom össze. Ezek a betük egyben szövegek is, ám még várakoznak, hogy megkapják ékezeteiket, magánhangzóikat, központozásukat, intonációjukat, hogy gyakorlatba ültessék öket. A szavak arra várnak, hogy szétszabdalódjanak és meghatározódjanak. Ez az a megtestesülés, amely nemes egyszerüséggel és alázatossággal kísérli meg a központosítást, a formázást, a neon aláhúzást, a betűképek és méretek változtatását. És számos nyelv lexikai meghatározásai tanúsítják azt, hogy ők maguk is szavakból épülnek fel, és még várnak a jelentésre. Egy szó definíciója saját használata. S a használat egy hontalan vándorlás és egy hiányzó Hanghoz való hüség. Vég nélkül való." [Uo. XVII-XVIII. o.]

${ }^{49}$ Erdély Miklós: Marly tézisek. In: MI. 128. o. 
Joseph Kosuthra tett utalás és egyben pontosítás, távolságtartás: „J. Kosuth azt mondja, hogy a filozófia vége a müvészet kezdete. Ezt úgy fogalmaznám, hogy a művészet kioltott filozófia."50 A Kosuth-parafrázist egyfelől feloldhatjuk úgy, Kosuth és Erdély teóriájával egyaránt harmonizáló módon, miszerint a mủvészet akkor jár helyes úton, ha elveszi a filozófia kenyerét. A müvészetnek nincsen szüksége elméletíróra, fogalmi kutatását magának kell elvégeznie. A müvész munkája Kosuth számára a tudóséhoz hasonlatos: ahhoz a tudóséhoz is, aki a laboratóriumban dolgozik, de főként azéhoz, aki a dolgozatain munkálkodik. ${ }^{51}$ Ahogy Erdély szintén a fogalmi kutatást preferálja, a gondolkodást teszi meg kiindulópontjául, azaz a müvészet alapja számára is a filozófiai kutatáshoz hasonlatos. Másfelől azonban a Kosuth-parafrázis határozottan két irányba mutat. Kosuth a filozófia végét a nyelvi fordulathoz és Wittgensteinhez köti, így a filozófia vége - és a müvészet kezdete - pontosabban a kontinentális filozófia végét jelenti: „És ha ráébredünk Wittgenstein gondolkodásának következményeire, az általa befolyásolt és az utána következő gondolkodásra - többé nem szükséges komolyan vennünk az európai »kontinentális filozófiát«.”52 Amint Lyotard írja Kosuthról: „Érvénytelenítette Wittgensteinnel együtt azt az örült jogot, amelyet a modern logika önhitten magának követelt - a diskurzus referenciájának pontos kifejezését propozícióinak tiszta tükrében.”53 Erdély számára viszont a filozófia vége a filozófia müvészeten belül történő kioltása. A

\footnotetext{
${ }^{50}$ Erdély Miklós: [A tézisek mellé...]. In: MI. 132. o.

${ }^{51}$ Lásd: Joseph Kosuth: Context text. In: Joseph Kosuth: Art after Philosophy and After - Collected Writings, 1966-1990. Ed. Gabriele Guerico. The MIT Press, Cambridge, Massachusetts, London, England, 1991. 86. o.

52 Joseph Kosuth: Art after Philosophy. In: Uo. 14. o.

${ }^{53}$ Jean-François Lyotard: Foreword: After the Words. In: Uo. XVIII. o.
} 
müvészet a gondolkodásnak az ellentétek feszülése mentén az önkioltás felé tendálása. És ez alól nincs kibúvó: a gondolati művészet így számára éppen, hogy a wittgensteini nyelvi-logikai határok megnyitásának is a lehetősége.

Ahová pedig mindezzel el akartam jutni: a konceptuális müvészet és annak analitikus beállítottsága Erdély Miklós esetében önmagából kiszédítve végül mégiscsak klasszikus idealista törekvések elérésének lehet a záloga. A Marly tézisek analitikus filozófián alapul, viszont oly módon, hogy Erdély az értelmezés terepének Kosuth-féle határain túlra mutat. A konceptuális müvészet Joseph Kosuth általi behatároló központi tendenciájából Erdély kifelé tekint. S a nyelvi-logikai térből való paradoxikus kilépések adják a lehetőségét annak, hogy a műalkotást végül mégis az igazság, a szépség és a szabadság új erőre kapó, az ürességig tisztult, klasszikus, kontinentális fogalmaival határozza meg. ${ }^{54}$

A Marly tézisekhez hozzákívánkozik az Erdély által többször megidézett Hegel két gondolata is. Ö a müvészettől mint „puszta

\footnotetext{
54 Meglehetősen erős ellenpontként Joseph Kosuth az Art after Philosophy programja szerint pontosan a klasszikus esztétikai diskurzus fogalomhasználatát akarja leválasztani a műalkotásokról, az elsődleges cél számára a klasszikus esztétika és a művészetek elkülönítése. [Lásd: Joseph Kosuth: Art after Philosophy. In: Joseph Kosuth: Art after Philosophy and After - Collected Writings, 1966-1990. Ed. Gabriele Guerico. The MIT Press, Cambridge, Massachusetts, London, England, 1991. 16. o.] Aporetikusan úgy fogalmazhatunk: amennyiben a konceptuális müalkotás célja a mủalkotás addig használatban lévő fogalmainak fogalmi úton történő megkérdőjelezése, úgy a Marly tézisek azért konceptuális műalkotás, mert fogalmi úton elindulva tör ki a mủalkotás kosuthi, analitikus felfogásának lehetőségeiből és érvényességi köréből is. A tézisek tehát szigorúan nem kosuthi értelemben vett konceptuális müalkotás - ugyanakkor a tézisek pontosan a kosuthi értelemben véve nagyon is szigorú, radikális konceptuális müalkotás.
} 
játszadozástól”, esetleges eszközeitől és különös, akár széttartó céljaitól elkülönítendő azt írja: „[...] [A] müvészet arra hivatott, hogy az igazságot az érzéki művészeti alakult formájában fedje fel, hogy ábrázolja a kibékített ellentétet, - s ezzel végcélja önmagában, ebben az ábrázolásban és felfedésben rejlik.” ${ }^{55}$ Mi pedig láthatjuk, hogy a szépség-igazság összefüggéseiben felmutatható, Erdély teóriáját a klasszikus német idealizmushoz füző rokoni szálak jelen esetben talán vékonyodnak, többször meg is csavarodnak, de semmiképp sem szakadnak el. Erdély Miért szép? Henry Moore: Király és királynő című írásában Moore szobra kapcsán az igazság és szépség együttállásáról a következőképpen fogalmaz: „[...] [A] kész müben, a remekmüben az ellentmondásos igazság hiteles egységbe rendeződése mint szépség jelenik meg." ${ }^{56}$ Az idézetet pedig a rész-egész viszonyának Erdélynél rendre visszatérő árnyalása miatt érdemes még egy mondat erejéig folytatnunk: „A részletek magyarázzák az egészet, az egész értelmezi a részleteket." ${ }^{57}$ Iposteguy Agyvelő címü szobráról írva pedig ugyanez, kicsit másképp hangsúlyozva: „A tudományos módszer, az analitikus szemlélet nem nyugtatja meg, sőt felkavarja [az újkori embert], mert a szétszedett emberben az ember nem

${ }^{55}$ G. W. F. Hegel: Esztétikai elöadások I. Szerk. Lukács György. Ford. Zoltai Dénes. Akadémiai Kiadó, Budapest, 1952. 56. o. Valamint: „A szépművészet [...] csak akkor teljesíti legfőbb feladatát, amikor közösséget vállal a vallással s a filozófiával, és csak egy módja az isteni, a legnagyobb emberi érdekek, a szellem legátfogóbb igazságai tudatosításának s kimondásának. [...] A müvészet igazi feladata ugyanis - mint már jeleztük - a szellem legmagasabbrendü érdekeinek tudatosítása.” [Uo. 9. o., 15. o.]

${ }^{56}$ Erdély Miklós: Miért szép? Henry Moore: Király és királynő. (1952-53, bronz, magasság: 164 cm). In: MI. 59. o.

${ }^{57}$ Uo. 
ismer önmagára.”58 Hegel Esztétikájának már-már programszerü indításában nagyon is hasonló módon a Wolff- és Baumgarten-féle esztétikától való szemléletbeli különbséget hangsúlyozandó vezeti be az esztétika helyett a művészetfilozófia, pontosabban a szépművészet filozófiája terminust. Mintegy az analitikus helyett az általa választott szemlélet is a filozófiai, müvészetfilozófiai. ${ }^{59} \mathrm{~S}$ hogy ez a szemléletválás milyen cél szolgálatában áll még? Ezzel Hegel - és Schelling - számára a művészetről való gondolkodás célja egyben a tetszés esetleges törvényein, a puszta ízlésítéleteken való túllépés. ${ }^{60} \mathrm{Az}$ ízlésítéletről pedig Erdély a

${ }^{58}$ Erdély Miklós: Miért nem szép Iposteguy Agyveleje? In: MI. 61. o.

${ }^{59}$ G. W. F. Hegel: Esztétikai elöadások I. Szerk. Lukács György. Ford. Zoltai Dénes. Budapest, Akadémiai Kiadó, 1980. 3. o. A neoavantgárd általános töredezettségéből a romantikus egész teljesség-eszménye felé nyúló szándékhoz máris idézzük Georg Simmel álláspontját is, melynek még a hasonlattal való leírása is rímel Erdély agyvelő-példájára. Eszerint az analitikus részekre bont, fragmentál, és ezen töredékek hatásait vizsgálja, viszont: „[...] [A] mű e tényezők összerakásából ugyanúgy nem állítható elő, belőlük éppoly kevéssé érthető meg, mint az eleven test a boncasztalon heverő szétszabdalt tagokból. [...] [A] döntő ezúttal is valami a részhatásokból kiemelkedő vagy rajtuk felülkerekedő teljes egység." [Georg Simmel: Rembrandt. Egy müvészetfilozófiai kísérlet. Ford. Berényi Gábor. Corvina, Budapest, 1986. X. o. Hegel, Schelling és Georg Simmel szemléletmódjának rokonságára Gyenge Zoltán Schelling élete és filozófiája címü könyvében hívja fel a figyelmet. Gyenge Zoltán: Schelling élete és filozófiája. Attraktor, Máriabesenyő - Gödöllő, 2005. 163-164. o.]

${ }^{60}$ Schelling szerint „faragatlan” az, aki müvészetfilozófiai háttér nélkül „,csak a műalkotások által ébresztett érzéki rezdüléseket, érzéki affektusokat vagy az érzéki tetszést tartja a művészet sajátképpeni hatásainak”. Azaz: „Aki tehát nem emelkedik fel az egésznek az ideájáig, az teljességgel képtelen megítélni bármilyen alkotást.” [Mindkét idézet forrása: F. W. J. Schelling: A müvészet filozófiája. (A kéziratos hagyatékból). Ford. Révai Gábor. Akadémiai Kiadó, Budapest, 1991. 66. o.] Ahogy pedig Hegel írja: „Mármost azonban a helyzet örökre az marad, hogy a mủalkotásokat vagy a jellemeket, a cselekvéseket $\mathrm{s}$ az 
német elődökhöz hasonlóan meglehetősen egyértelmü véleményen van: „[...] [N]incs az ízlésnek köze a müvészethez."61

A Marly tézisekhez visszatérve: Erdély gondolataiban a kosuthi értelemben vett konceptuális művészet kereteinek a szétfeszítése, a műalkotás fogalmi-nyelvi-logikai határainak az átlépése történik. S ez egyben a szabadság elérésének a záloga. A záró tézisek szerint a müalkotás nem csupán az egyedi meghatározások egymást szétfeszítésén át elérhető szépség határtalanul üres koncepciója: a mủalkotás terve egyben a szabadság terének az előkészítése is.

- A mủalkotás üzenete az üresség, ami a sajátja.

• A befogadó ezt az ürességet fogadja el.

eseményeket mindenki saját nézetei s kedélye mértéke szerint fogja fel, és mivel ez az ízlésképzés csupán a külsőre és hiányosra irányult, és ezenkívül a maga előírásait a műalkotásoknak is csak egy szük köréből és az értelem s a kedély korlátolt müveltségéből vette, így hát szférája elégtelen, maga pedig képtelen volt arra, hogy a bensőt $\mathrm{s}$ az igazat ragadja meg és a tekintetet ennek felfogására élesítse meg.” [G. W. F. Hegel: Esztétikai elöadások I. Szerk. Lukács György. Ford. Zoltai Dénes. Budapest, Akadémiai Kiadó, 1980. 17-18. o.]

${ }^{61}$ Téma: A költészet. Az Indigo csoport beszélgetése az Erdély Miklós Költői avantgarde című pécsi előadásához kapcsolódó kiállításról 1979. november 7-én. In: KGYFI. 275. o. Az idézett mondat után lett vége a második kazettának, s mire a harmadikat betették, természetesen a beszélgetés egy része erről már lemaradt. Valahol ott folytatja Erdély, hogy az állandó, az örökké érvényes és a divat különbségéről beszél, aztán egy friss olvasmányélménye kapcsán - az előző éjjel olvasta Erich Fromm egy írását - hosszasan elmeséli, hogy Párizsban látott egy hipnotizőrt, aki a legellenállóbb alakokat is könnyüszerrel hipnotizálta. Majd a történetet a következőképpen csatolja vissza a tetszés egyszerü törvényéhez, a könnyedén manipulálható, esetleges ízlésítélethez: „[...] [H]ogy ha ilyen minimális eszközökkel abszolút manipulálható egy ember, akkor az egész társadalom hipnózisa mennyivel erősebb. Azt tudom, hogy én hipnotikus állapotban vettem meg ezt a kabátot, mert ez tetszik nekem. Nem az a lényeg, hogy én ezt tudom, hanem hogy örületesen tetszik." [Uo.] 
•• A műalkotás helyet készít a befogadóban, amikor üzenetét a befogadó »megérti«.

$\bullet \bullet \bullet \bullet$ A befogadó ilyenkor azt mondja: »szép«, ami szintén üres kijelentés.

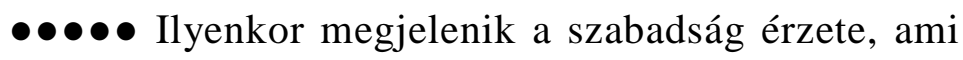
semmi más, mint üresség, lyuk a »felismert szükségszerűség « láncolatában: hely.

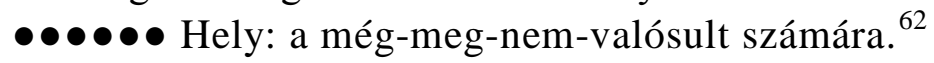

Erdély Miklós törekvéseiben a szép és az igaz együttállását kiegészíthetjük a szépnek a szabadsággal való összefonódásával. Gondolatainak egésze, a montázs körülírása megegyezik a szabadság lehetőségének leírásával. ${ }^{63}$ A tézisek a művészet egymást zárójelező meghatározásaitól elemelkedve mutatják az irányt a szabadság, a mindig új, az ismeretlen felé - amivel szemben mindenki már csak önmagában állhat. Ahogy Erdély az ELTE Esztétika Tanszékén 1981-ben elhangzott Optimista elöadásban mondja: „[...] [A] meg nem értettel szemben

${ }^{62}$ Erdély Miklós: Marly tézisek. In: MI. 128. o.
${ }^{63}$ Itt persze ismét idézhetjük Hegelt: „Mármost azt a legmagasabbrendü tartalmat,
amelyet a szubjektív önmagában felfogni képes, röviden szabadságnak nevezhetjük. A szabadság a szellem legmagasabbrendủ meghatározása.” [G. W. F. Hegel: Esztétikai előadások I. Szerk. Lukács György. Ford. Zoltai Dénes. Akadémiai Kiadó, Budapest, 1952. 99. o.] Tábor Ádám megfogalmazásában: „A nyelv jelentéskonzerváló ereje, akárcsak a tömegvonzásé, legyőzhető ugyan, de nagy árat kell érte fizetni; és minden egyes esetben fel kell tenni a kérdést, hogy megéri-e. Az igazi neoavantgárdisták szerint persze igen - én magam soha nem tudtam lakóhelyül a Föld helyett a csillagokat, a szülőföld helyett egy új világot választani; nyilván ezért is írhatok most és itthon minderről.” [Tábor Ádám: A váratlan kultúra - Esszék a magyar neoavantgárd irodalomról és müvészetröl. Balassi Kiadó, Budapest, 1997. 64. o.] S ehhez egy alapvető dilemmára figyelmeztető intésként - melynek Erdély gondolatain belüli feloldását majd a későbbiekben fejtem ki - idézzük azt is, hogy „[...] egyrészt a szabadság magáértvéve, mint szubjektív szabadság, a szükségszerütől elválasztva, nem abszolút igaz, másrészt az önmagáért elszigetelt szükségszerűségnek sem tulajdoníthatunk igazságot.” [G. W. F. Hegel: Uo. 102. o.] 
mindenki teljesen egyedül áll, tehát megszünik az a bizonyos sorba kapcsolás - elektronikai példát hozva -, hogy egy hierarchián keresztül jut minden fontos, minden lényegi dolog el az egyénhez.”“4 És ez a bármiféle hierarchiából kivezető út az, ami miatt a Marly tézisek utólag igazán kiemelkedőnek, maradandónak, a naptári időszámítástól és a múlékony stíluskategóriáktól is függetlennek bizonyulhat.

Erdély Miklós tehát a par excellence konceptuális müvészet kiemelkedő alakja. Csakhogy ehhez a mondathoz legalább három, két rövidebb és egy hosszabb, már a formát öltött gondolatokra is kitérő kiegészítést kell hozzátennünk.

Az első Erdély művészet(elmélet)ének recepciójára vonatkozik. Létezik róla egy olyan - egyébiránt nem is teljesen alaptalan - elgondolás, miszerint konceptuális müvészként a posztmodern magyarországi előhírnöke lett volna, Balassa Péter kifejezésével egyfajta „predekonstruktivista”. ${ }^{65}$ Annak bemutatásával, hogy Erdély teóriája több

\footnotetext{
${ }^{64}$ Erdély Miklós: Optimista előadás. In: MI. 147. o.

${ }^{65}$ Balassa Péter: Erdély Miklós mint predekonstruktivista. In: Kritika. 1999/1. sz. 35-36. o. Lásd még: Balassa Péter: Erdély Miklós mint írás. In: Magyar Mühely. 1999. XXXVII. évf. 110-111. sz. 44-48. o.; Perneczky Géza: Erdély Miklós, és műve, a dekonstruktív tautológia. In: Erdély Miklós /1928-1986/. Kiállítási katalógus, Csók István Képtár, István Király Múzeum, Székesfehérvár, 1991. október 26. - december 31. 5-24. o. Újraközölve: Uő: Erdély Miklós és műve: A dekonstruktív tautológia. In: Perneczky Géza: Zuhanás a toronyból. Válogatott írások 1983-1994. Enciklopédia Kiadó, Budapest, 1994. 105-122. o.; Müllner András: Nagytestű prémes állatok. Néhány szó Tandoriról és Erdélyről egy recenzió keretében. In: Fogaras György - Müllner András: Rátévedések - a romantikában, a neoavantgárdban és más területeken. Ictus Kiadó és JATE Irodalomelmélet Csoport, Szeged, 1998. 132-146. o.; Müllner András: Az önreflexió mint „irodalomtörténeti fordulat”. Erdély Miklós: Metán. In: Uo. 147174. o.; Pomogáts Béla: Ismeretelmélet mágikus térben. Jegyzet Erdély Miklós
} 
ponton kötődik a klasszikus német idealizmushoz és a transzcendentálfilozófiához, legalábbis azt szerettem volna érzékeltetni, hogy Erdély pozícionálása semmiképp sem lehet egy irányba tartó.

A második, lényegesen hosszabban leírható kiegészítés az, hogy Erdély Miklós fluidumszerü törekvései az analitikus konceptualizmusnál szinte mindig jóval nagyobb terepen mozognak: ha gondolatai a müvészet belügyeinek elvont elméleti problémái körül forognak, hirtelen irányváltásaival akkor is szinte mindig a lehető legtágabb perspektívát nyitják meg. És ez „csupán” az egyik vetülete törekvéseinek. Erdély viszonylag korán jelentkező aggálya a konceptualizmussal szemben az, hogy túlzottan lemondott az érzékiségről. Néhány mondatban: a konceptuális művészet szűkre szabott terrénumát többen, többféleképpen kiterjesztették, ám a kezdeti domináns meghatározások mindegyikében közös, hogy a tiszta gondolatiságban rejlő ötletet, az ideát tekintették a mü esszenciájának. Eszerint a mủ alapja - avagy az egésze - a gondolat, az ötlet, az idea; s ehhez mérten a tárgyiság, a forma, a kivitelezés csupán másodlagos. Sol LeWitt 1967-ben az Artforum hasábjain tette közzé

költészetéröl. In: Magyar Mühely. 1999. XXXVII. évf. 110-111. sz. 13-16. o.; Tarjányi Eszter: A szellem örvényében. Universitas Könyvkiadó, Budapest, 2002. 231-237. o.; Hornyik Sándor: Naiv realizmus és „természettudományos koncept”. A modern természettudomány helye Erdély Miklós müvészetében. In: Magyar Mühely. 2004. XLIII. évf. 131. sz. 46-50. o.; Krusovszky Dénes, Urfi Péter: „Nehézkesen forduló tankhajó” (interjú Kukorelly Endrével). In: Puskin Utca. 2008/4. sz. 29-32. o.; Valamint lásd Kukorelly Endre átfogó pillantását: Kukorelly Endre: 666 999000. Előbb némi szívdobogás, kissé zajos, rendben, tehát: valamit a magyar irodalomról. Monológ. In: 2000. MM április, 12. évf. 4. sz. 52-72. o. Újraközölve: Kukorelly Endre: $666999^{000}$. Előbb némi szívdobogás, kissé zajos, rendben, tehát: valamit a magyar irodalomról. Monológ ${ }^{00}$. In: Né/ma? Tanulmányok a magyar neoavantgárd köréböl. Szerk. Deréky Pál és Müllner András. Ráció Kiadó, Budapest, 2004. 315-347. o. 
bekezdéseit: „A konceptuális müvészetben az ötlet vagy koncepció a munka legfontosabb aspektusa. [...] Nem igazán fontos, hogyan néz ki a müalkotás. Valamilyennek ki kell néznie, ha fizikai formája van. Nem számít, hogy végül milyen formát kap, egy ötletből kell kiindulnia."66 Majd az 1969-ben közölt Sentences on Conceptual Artban kicsit másként:

10. Egyedül az ideák lehetnek müvészeti alkotások. Egy fejlődési lánc részei, s végül saját formára találhatnak. Nem minden ideát szükséges fizikálissá tenni.

[...]

13. Egy mủalkotás felfogható a művész elméje és a néző közötti közvetítőként. Ám nem biztos, hogy ez valaha is eléri a nézőt, vagy hogy elhagyja a művész elméjét. ${ }^{67}$

De idézhetünk Lawrence Weinertől is, aki az elanyagtalanodást tökéletesen teljesítő 1969-es January Show címü kiállítás katalógusában azt állítja:

1. A müvész kigondolhatja a müvet.

2. A mü előállítható.

3. A művet nem szükséges elkészíteni. ${ }^{68}$

${ }^{66}$ Sol LeWitt: Paragraphs on Conceptual Art. In: Art in Theory - 1900-1990 - An Anthology of Changing Ideas. Ed. Charles Harrison and Paul Wood. Blackwell Publishers Inc, Oxford UK \& Cambridge USA, 1999. 834-835. o. (Sol LeWitt 1967-ben közölt bekezdéseiben találkozhatunk elöször a 'Conceptual Art' kifejezéssel. Joseph Kosuth kikerülhetetlen Art after Philosophy címü írása valamivel később, 1969-ben, három részletben jelent meg a Studio Internationalban.)

${ }^{67}$ Sol LeWitt: Sentences on Conceptual Art. In: I.m. 838. o.

${ }^{68}$ Beke László az 1971-ben meghirdetett Elképzelés című projektjéhez Weiner idézett statementjét választja mottóul. Lásd: http://www.c3.hu/collection/koncept/images/elkepzeles.html; 2013. 04. 10.

A mü elanyagtalanodását, a dematerializációt Lucy R. Lippard és John Chandler fejtik ki elsőként a The Dematerialization of Art címü, 1968-ban publikált írásukban. Szerintük a dematerializáció nem pusztán a tárgyiságtól 
megszabaduló redukció nyomon követhető folyamata - melynek ekkor még nem értek el a nullpontjáig és az azt követő rematerializációig -, hanem, ami ennél sokkal mélyebb meghatározás, az anyagtalanság a mü alapvető létmódja: a mü, akár van tárgyiasult formája, akár nincs, a gondolatban egzisztál. Cikkükböl legalább egy passzust olvassunk el, mely két szempontból is fontos lehet számunkra. Az egyik, hogy ebből is kitünik, Lippard és Chandler egyáltalán nem zárkóznak el a klasszikus, kontinentális gondolkodás fogalomhasználatától, azaz nem kizárólag a Kosuth-féle analitikus szemléletet követik. A másik pedig az, hogy a gondolat mindent átölelő szépségéröl írva a természettudomány gondolkodásmódját említik: Richard Feynman mellett a kvarkokat felfedező Murry Gell-Mannt idézik, akit Erdély Miklós, Urbán Miklós, Cseh Tamás és Szentjóby Tamás szintúgy megidéznek, pontosan Lippardék írása évében, 1968ban. „A dematerializált müvészet poszt-esztétikai jellege pusztán a vizualitás mellőzésének hangsúlyozásában rejlik. Ám az alapelv továbbra is esztétikai, ahogy azt a matematikusok és a tudósok egyenletek, formulák vagy megoldások szépségéről szóló gyakori kijelentései is sejtetik: »Miért kellene egy esztétikai kritériumnak oly gyakran eredményesnek lennie? Mert a fizikusok számára ez a kielégítő? Én azt hiszem, erre csak egy válasz létezik - a természet önnön magában is szép.« (A fizikus Murray Gell-Mann.) »Ebben az esetben volt egy pillanat, amikor pontosan ráéreztem a természet müködésére. Eleganciát és szépséget hordozott magában. Az az istenverte dolog ragyogott.« (A Nobel-díjas Richard Feynman.) Minél tovább olvassa valaki ezeket a kijelentéseket, annál nyilvánvalóbbá válik, hogy a tudósok azon törekvése, mely a felfedezésre, sőt, még inkább az univerzum rendszer és szerkezet alá kényszerítésére irányul, olyan feltételezéseken nyugszik, melyek lényegileg esztétikaiak. A rend maga, az önmagában hordozott egyszerüségében és egységességében, esztétikai kritériumok összessége.” [Lucy R. Lippard - Johny Chandler: The Dematerialization of Art. In: Conceptual Art: A Critical Anthology. Ed. Alexander Alberro, Blake Stimson. The MIT Press, Cambridge, Massachusetts, London, England, 1999. 48. o. Érdemes elolvasnunk Terry Atkinson Lippardékhoz írt levél-esszéjét is, melyben az általuk bevezetett 'dematerializáció'-terminust több oldalról pontosítja: Terry Atkinson: Concerning the Article »The Dematerialization of Art«. In: I.m. 52-58. o.] Lippard néhány évvel később, az 1973-ban megjelent könyvének utószavában a konceptuális művészet első szakaszát összegezve arról ír, hogy az interdiszciplináris tudás művészeti alkalmazása az általa vizsgált terepen rutinná vált, a túlegyszerüsítés 
Erdély alkotói módszerében az ötlet, a gondolatiság elsőbbségének talán legdirektebb megfogalmazása egy 1979-es munkája, mely az Iparterv 1968-1980 kiállításra készült: Az elmúlt tíz év alatt megvalósult, illetve nyilvánosságot kapott elképzelések aránya a rögzített elképzelések (tervek, vázlatok) viszonylatában. Erdély saját alkotásairól szóló számvetése egy grafikon, mely két, a címben adott függvényt ábrázol közös koordinátarendszerben: egy szaggatott vonalat látunk, mely az elképzelések mennyiségét ábrázolja, és egy folyamatost, a megvalósult ötletek számának ívével. A két görbe a tengely kezdetétől, 1969-től széttart egymástól: egyre magasabbra tör az elképzelések száma, miközben folyamatosan csökkennek a megvalósulások. A tendencia valahol 1973 környékén törik meg. Ekkortól radikálisan csökkennek az elképzelések, majd 1975-töl finoman növekedésnek indulnak a megvalósulások, mígnem 1978-tól a két függvény már egymás mellett halad. A grafikon egyértelművé teszi, hogy Erdély számára a gondolatiság a kezdete és az alapja az alkotásnak, ám azt is természetesnek veszi, hogy egy ötlet felbukkanása még semmiképp sem egyenlő a mü megvalósulásával, ahogy a mủvészi tevékenység nem merül

áldozatául esett. Többek közt ezzel magyarázza, hogy a művészet és a matematika, a mủvészet és a filozófia közötti interakció - néhány kivételtől eltekintve - kezdetleges szinten ragadt meg. Lippard szerint '73-ra kétségessé vált, hogy a konceptuális müvészet valaha is nagyobb hatást fejtsen ki a világra, de azért lát még némi okot a reménykedésre. [Six Years: The Dematerialization of the Art Object from 1966 to 1972. Ed. Lucy R. Lippard. Praeger, New York, 1973. 263-264. o. Újraközölve: In: Conceptual Art: A Critical Anthology. Ed. Alexander Alberro, Blake Stimson. The MIT Press, Cambridge, Massachusetts, London, England, 1999. 294-295. o.] 
ki az elképzelések rögzítésében sem - a gondolatiságnak ennél többre van szüksége ahhoz, hogy elérje a felszínt, hogy nyilvánosságot kapjon. ${ }^{69}$

A konceptuális müvészet és Erdély Miklós közös vonatkozási pontja - Wittgensteinen túl - Marcel Duchamp. Erdély az INDIGO csoporttal beszélgetve az elanyagtalanodás kezdetét egyenesen Duchamphoz köti:

Ez a legelemibb avantgarde mozdulat volt. Ezt Duchamp csinálta..., hogy a kiállítási terem és a külvilág közötti ellentmondást kihasználta úgy, hogy mind a kettőnek a jelentését kioltotta. Se kiállítás nem volt, se mütárgy, se semmi. Ebben a pillanatban elkezdődött a müvészet önmagára ébredése. Akkor hol van a müvészet? Se itt nincs, sehol nincs... Ennek a konzekvenciáját végre le köll vonni. Halálbiztos, hogy ebben a pillanatban megjelent a művészet egy teljesen anyagtalan formában. [...] Ez az a tett, amikor még a hülyének is észre köllött venni, hogy a müvészet nem a tárgyban van benn, és egyáltalán sehol sincs a müvészet, hanem - van. Egyszerüen nem lehet semmiféle helyhez kötni, ezt neveztem az elöbb leszakadó buboréknak. Ebben a pillanatban teljesen anyagtalanná vált a dolog, és a

${ }^{69}$ A munkához lásd: Bardi Teri: A senki földjén voltunk... Beszélgetés Sugár Jánossal. In: Beszélő. A senki földjén. A Beszélö melléklete Erdély Miklósról. 1991. október 26. Új folyam II. évf. 43. sz. 8-10. o.; Sugár János: Emigráció a festészetbe. Erdély megvalósult és meg nem valósult müvei. In: Új Müvészet. 1999. március, X. évf. 3. sz. 8-10. o. Újraközölt változatok: Uő: Emigráció a festészetbe. Erdély megvalósult és meg nem valósult müvei. In: Magyar Mühely. 1999. XXXVII. évf. 110-111. sz. 104-108. o.; Uő: Emigráció a festészetbe. In: KGYFI. 453-457. o.; Kapitány András: Erdély Miklós munkáinak bemutatása diagram segítségével, 1969-1979. Interneten: http://www.c3.hu/collection/em/; 2013. 04. 07. 
müvészet elkezdett sehol se lebegni. Ezt tudatosítani köll. $^{70}$

Az 1974-ben, Pécsett megrendezett IV. Országos Kisplasztikai Biennáléra beadott jelentkezési lapján Erdély, arra a kérdésre, hogy kit tart mesterének, Bokros Birman Dezső mellett még Marcel Duchamp-t jelölte meg. Ám ahogy távolodott a korai konceptuális művészettől, úgy változott meg a viszonya Duchamp-mal is. Ami biztos, a ’70-es évek elején még markánsan kötődött hozzá, és rajta keresztül a konceptuális müvészethez is. Ezt mutatja az „R”-kiállításon 1970-ben bemutatott Váza virággal címet viselő konceptuális „festménye” (mázas kerámiaváza, víz, vágott rózsa) és a Tavalyi hó című munkája is (termosz, tavalyi hó). ${ }^{71}$ De hasonló köteléket

${ }^{70}$ Téma: A költészet. Az Indigo csoport beszélgetése az Erdély Miklós Költői avantgarde című pécsi előadásához kapcsolódó kiállításról 1979. november 7-én. In: KGYFI. 274. o.

${ }^{71}$ Az említett munkákról, valamint Erdély és Duchamp viszonyáról lásd még: Rózsa T. Endre: Az utak összeérnek? In: Kritika. 1971/6. sz. 56. o. Újraközölve: In: Ars Hungarica. 1991/1. sz. 128. o.; Peternák Miklós: A konceptuális müvészet hatása Magyarországon. 1983-85. Interneten: http://www.c3.hu/collection/koncept/help.html; 2012. 11. 23.; Peternák Miklós: concept.hu | koncept.hu. A konceptuális müvészet hatása Magyarországon. The Influence of Conceptual Art in Hungary. Paksi Képtár - C3 Alapítvány, 2014. 33-36. o.; Sinkovits Péter: A magyar avantgárd Székesfehérvárból nézve. In: Müvészet. 1988. május, XXIX. évf. 5. sz. 33. o.; Forgács Éva: A neoavantgárd magánya. Erdély Miklós: Müvészeti írások. (Válogatott müvészetelméleti tanulmányok). In: Új Müvészet. 1992. április, III. éfv. 4. sz. 81-84. o.; Görényi Frigyes: A vállalt előd adva van. Marcel Duchamp magyarországi recepciója. In: VISZONTLÁTÁSRA! DUCHAMP. Készült a VISZONTLÁTÁSRA! • Marcel Duchamp magyarországi hatásai c. kiállításhoz, Budapest Galéria Kiállítóháza, 1996. november 14. - december 8. Budapest Galéria, Budapest, 1996-2000. 5-24. o.; Beke László: Görényi Frigyes: Marcel Duchamp. In: Uo. 42-44. o.; Szőke Annamária: Erdély Miklós: Tavalyi hó. 1970. In: Uo. 55-56. o. A Kisplasztikai Biennáléra beadott jelentkezési lap másolatát 
sejtet az 1979-ben, Jovánovics Györgyröl írt Önlehallgatás címü esszéjéhez csatolt Képregény egy sakkparti állásáról is. ${ }^{72}$ És persze az, hogy 1973ban, Balatonbogláron Jovánovics Györggyel és Major Jánossal közösen kiállítottak egy „talált” ruhadarabot - Major János kabátját -, Major János kabátja címen, a következő szöveg kíséretében: „Avantgardista tettnek minősíthető-e, hogy Erdély Miklós, Jovánovics György és Major János közösen kiállítottak egy kabátot? [...] [A]z avantgardizmus helyzete most [...] problematikusnak látszik, s a fő probléma magából az avantgardizmus lényegéből, alapvető kritériumából, a szüntelenül az újra irányuló törekvésből következik. Ugyanis az avantgardista művész önmagát és a többi avantgardistát kényszerül korlátozni minden egyes új mü létrehozásával, ugyanolyat vagy lényegében hasonlót többé egyikük sem csinálhat. [...] E kabátban, melyet közösen állítottunk ki, kísérletet látok az avantgardizmus felszabadítására. E mü már nem tartalmaz semmiféle új motívumot. Ruhadarabot kiállítani nem új. Claes Oldenburg állított ki nadrágot 1962-ben. Nem új, hogy három müvész közösen vállal egy alkotást. Közismert példa erre a Kukrinyikszi-együttes. Nem új, hogy mütárgyat, az általa felvetett problémát értelmező szöveg kíséretében

lásd: Uo. 60. o.; Németh Gábor - Sebők Zoltán: Az utca művészete. (Németh Gábor és Sebők Zoltán beszélgetése). In: Új Forrás. 2004. október, XXXVIII. évf. 8. sz. 99. o.; Mezei Ottó: Háromnapos bemutató a Műegyetem R épületében. (Kézirat a hagyatékban, 1970-1971) In: Uő: Magyar, európai, modern. Válogatott írások. Vál. és szerk. Andrási Gábor, Pataki Gábor. Argumentum Kiadó, MTA Bölcsészettudományi Kutatóintézet, Mủvészettörténeti Intézet, 2013. 253. o.; Kótun Viktor: Neoavantgárd müvek rekonstruálásának gyakorlata. DLA értekezés, Magyar Képzőművészeti Egyetem, Doktori Iskola, Budapest, 2013. 6667. 0.

${ }^{72}$ Erdély Miklós: Önlehallgatás. Képregény egy sakkparti állásáról. In: MI. 1113. 0. 
állítanak ki. Ez a koncept-art fő jellemzője (Joseph Kosuth). És az sem baj, mert az se új, hogy nincsen benne semmi új.”73

Erdély Peternák Miklóssal beszélgetve egészen pontosan 1976-ra teszi az idejét annak, amikor, ahogy mondja, a gondolatiságról már a vizualitásra helyezte át a nagyobb hangsúlyt, szakítva a „koncept arttal”. ${ }^{74}$ 1981-ben, az Optimista előadásban pedig úgy fogalmaz: „Nem akarok kitérni a koncept artra, mert szerintem az egy levitézlett időszak - ahol a levitézlettsége alatt semmi pejoratívat nem értek -, ez már elmúlt, mégpedig azért, mert túlságosan lemondott az érzéki, a közvetlen, a totális hatásról, amit a kommunikációban a müvészet mindig is igénybe vett. A művészet újra a vizuális és az érzéki hatásokat keresi." 75

Nos, nekünk itt, ennél az időszaknál kell még feltétlenül elidőznünk. A ’80-as évek kezdeténél, mikor Erdély mindinkább a „vizuális és érzéki hatásokat” keresi, mikor gondolatai egyre inkább megfoghatóvá, élményszerűvé, érzékivé válnak - s majd csak aztán írhatjuk le a harmadik kiegészítést ahhoz az állításhoz, miszerint Erdély Miklós a konceptuális művészet kiemelkedő alakja.

A '80-as évek eleje sűrü, burjánzó, érett alkotói periódust jelent Erdély Miklós életmüvében: a mediális kísérletezések többirányú kiteljesedését és a művészet társadalmi szerepvállalásának újra fellobbanó igényét. Ám ezekben az években a honi művészeti életben is jól kitapintható változások indultak meg. Beke László 1981-ben rendezte meg

\footnotetext{
${ }^{73}$ A szöveget lásd: Mi az avantgardizmus? In: Törvénytelen avantgárd. Galántai György balatonboglári kápolnamüterme 1970-1973. Szerk. Klaniczay Júlia és Sasvári Edit. Artpool-Balassi, Budapest, 2003. 154. o.

${ }^{74}$ Peternák Miklós: Beszélgetés Erdély Miklóssal 1983 tavaszán. In: Árgus. 1991. szeptember-október, II. évf. 5. sz. 80. o.

${ }^{75}$ Erdély Miklós: Optimista előadás. In: MI. 147. o.
} 
a '70-es évek tendenciáit bemutató kiállítás-sorozat hatodik, záró darabját, melynek a Posztkonceptuális tendenciák címet adta, a poszt- prefixummal utalva az időközben végbement átalakulásokra. ${ }^{76}$ A kiállítás címe akár még az ekkor erőre kapó posztmodern kultúrával is egybefonódva láttathatja a konceptualizmus és a neoavantgárd tovább tekeredő indáit, ám a posztelőtag Beke esetében itt inkább a személyes életutak irányváltásaira utal. A szüken értelmezett konceptuális müvészet meghatározó jelenlétének végére, és a végbement változásokat egybefogva a neoavantgárd első nagy lendületének lecsillapodására.

Erdély a Posztkonceptuális tendenciák tárlaton, mintegy jelezve a konceptuális müvészet lecsengését, a 'koncept art' skatulya számára már mindenképpen szükös - csaknem rágalomszerü - mivoltát, a mindent bekebelezni akaró gondolatiságot háttérbe kényszerítve állította fel Rágalomkristályok címü installációját. Pontosabban munkája a gondolatiságot nem is a háttérbe, hanem tisztes távolságba kényszerítette: csak távolról lehetett szemlélni a kátrányfőző üsttől kiinduló, szabálytalan mintában felállított, élükkel és lapjukkal egymásnak támaszkodó 14-15 darab üveglap törékeny egyensúlyát. Csak távolról lehetett szemlélni a legstabilabban álló elemből, a kátrányos üstből kivezető fekete fonalat és az üstnek támaszkodó üveglapokat, mert a formáció belső egyensúlya bármely kisebb behatásra megbomlott volna. Az installáció jelentésstatikáját maga Erdély érzékeltette: az üstöt megmozdítva maga borította fel az építményt. A kátrányföző üst dominószerűen döntötte le az üveglapokat, melyek kristályszerű mintázatban borultak egymásra, anélkül, hogy megsérültek volna. S hogy a megközelíthetetlen üstből merre tartott a

${ }^{76}$ „Kemény és lágy” - Posztkonceptuális tendenciák. Tendenciák 1970-80. 6. Óbudai Galéria, Budapest, 1981. április 14. - április 30. 
fekete fonál? A másik vége egy üveglappal fedett falépcsőig vezetett, melynek fokai be voltak terítve a tetején álló zsákokból kiömlő rózsaszín mütrágyával. Ahogy pedig az installáció alcíme instruálja a konceptuális művészetet poszt-ját kereső tárlatlátogató publikumot: Rágalomkristályok. A mütrágyán kell gondolkodni. ${ }^{77}$

77 Lásd még: Szőke Annamária: Erdély Miklós műveinek restaurálása és rekonstrukciója. In: Magyar Mühely. 1999. XXXVII. évf. 110-111. sz. 132-133. o.; Beke László: Erdély Miklós munkássága. Krono-logikai vázlat képekkel 1985ig. In: Erdély Miklós. Kiállítási katalógus, Óbuda Galéria, Zichy Kastély, 1986. április $\quad 11 . \quad-\quad-\quad$ május $\quad 5 . \quad 24-25 . \quad 0 . ;$ http://www.artpool.hu/Erdely/mutargy/Ragalomkristalyok.html; 2013. 04. 23.

Erdély 1980-tól mind gyakrabban használja az üveglap motívumát. Üveglapokat használ 1980-ban az Iparterv 68-80 kiállításon felépített Borisz Godunovhoz, Budapesten és Gentben A kalcedoni zsinat emlékére készített environmentjéhez, valamint a Wilhelmshavenben felépített Südstrand (Horizont nélkül) címü munkájához. De szintúgy üveglapokból építkezik Altorjai Sándornál Szigligeten Mesterdalnokok címen, valamint üveglapokat használ az INDIGO csoport Festmény és a Legszebb nyári élményem címü bemutatóin is. Az üveglapokból építkező metaforikus jelentések Erdély interpretációja szerint több, egymással érintkező jelentésréteggel bírnak: „[V]íz, időtlenség, pihenés, törékenység, némaság, transzparencia, lefektetve átláthatatlanság.” [Erdély Miklós: Előadás a kiállításról. (Magnófelvétel után). In: MI. 148. o.] A Rágalomkristályok üveglapjainak egyensúlyához és jelentés-statikájához a Stabilizáció és a Kényes egyensúly (Veszély) címü akciómunkái állnak legközelebb. Mindkét environmentje az anyagok legtisztább fizikális interakciójával és az egyensúly közvetlen fizikai tapasztalatával utal a bemutatók helyszínének törékeny politikai helyzetére. 1980 januárjában megbetegedett, majd a mütétjét követő szövődmények következtében május 4-én meghalt Josip Broz Tito, Jugoszlávia elsőszámú vezetője. Halálával szinte azonnal felszínre kerültek a délszláv államok közösségének gazdasági, nemzeti, nemzetiségi, vallási és kulturális feszültségei, majd egyre erősebb hangot kaptak az egymással szembeni sérelmei és széttartó törekvései. A hírek és jóslatok ezekben a hónapokban az ország esetleges széthullásáról, a gyúlékony helyzet stabilizálásának szükségességéről, a föderációt alkotó tagköztársaságok törékeny, de talán még 
kiegyensúlyozható viszonyáról szóltak. A Tito által kialakított, elviekben a tagállamok konszenzusán alapuló rendszert azonban a tényleges irányító, a „délszláv népek utolsó császára” nélkül csak rövid ideig lehetett fenntartani. 1981. március 11-én gazdasági és szociális elégedetlenségektől motivált albán diáktüntetés tört ki Prištinában - főként egyetemi diákok és diplomás munkanélküliek vonultak az utcákra -, mely csakhamar nacionalista demonstrációkba és zavargásokba csapott át, követelve az 1963 óta tartományi önkormányzati státussal bíró, 1974-től pedig csaknem köztársasági jellegü jogosítványokkal rendelkező, túlnyomó többségében albánok lakta Koszovó köztársasági önállóságát. A zavargásokat a jugoszláv hatalom a katonaság bevonásával brutálisan elfojtotta. A hivatalosan kilenc áldozatot követelö eseményt hatások és ellenhatások nacionalista törekvéseket erősítő, majd végül tragédiába torkolló egész sorozata követte. Az albán szeparatista indulatok a szigorú szerb ellenőrzés alatt csak tovább fokozódtak, ami táptalajul szolgálhatott az izzásra kész szerb nacionalizmusnak, a Jugoszlávia irányító szerepét megcélzó szerb törekvések pedig - az ekkorra felerősödő gazdasági nehézségekkel, de főként a terhek egyenlőtlen viselésével együtt - más köztársaságok nacionalista szólamait is lángra lobbantották. Ezen a terepen léphetett színre Slobodan Milošević, Franjo Tuđman és Alija Izetbegović. A Stabilizációt 1980 decemberében Zágrábban, a Galerija Savremene Umjetnostiban mutatta be Erdély. Cementporréteg fölé a sarkaikkal egymást támasztó üveglapsáncot állított fel, hófogórács-formára, mely távol tartotta a közönséget és magát is a mögöttük ferdén, spárgával felfüggesztett üveglapoktól. Egy hosszú pálca végére kést rögzített, melyre újságpapírdarabokat szúrt fel, meggyújtotta azokat, majd a sánc mögül a ferdén álló lapok alá helyezte, míg az újságok egy másik részét meggyújtva, de már a kés hegyén történő szállítás nélkül, ugyanoda dobta. A távvágóval elvágta a spárgákat, s a ferde lapok egyenként a cementporrétegre és a fellobbanó hírekre csapódtak. A kavargó pernye egy részét az eldőlt lapok rögzítették, maradékát pedig a hófogórács fogta fel. Az akció egyszerre dramatizálta a gyúlékony politikai helyzetet, és rögzítette, stabilizálta a folyamatot egyfajta narratív environmentként. [Zágrábba Erdély Maurer Dórával utazott el, eredetileg a filmjeik vetítésére, ahol végül mindketten kiállítottak. Ivan Ladislav Galeta, a Zágrábi Egyetemen müködő Multimédia Kutatások Központ művész-igazgatója hívta meg őket a vetítésre, majd a megérkezésükkor szólt a Galerija Grada Zagreba egy munkatársa, Marijan Susovski által felajánlott, rögtönzött kiállítás lehetőségéröl, mely végül Stabilizáció - Artikuláció címen 
valósult meg. A vastag cementporréteg, az üveglapok pontos helyzete, statikája és a történés az akción jelen lévő Maurer Dóra fotói és emlékei alapján tisztázható. Maurer Dóra a kiállításra ekkor, a szállodai szobájában készítette el Zsilipek címü sorozata por-változatának grafikáit, Artikuláció címmel. Ezúton is köszönöm Maurer Dóra segítségét. Lásd még: Havas Fanny: Egy valódi mester. Beszélgetés Maurer Dórával. In: Beszélö. A senki földjén. A Beszélő melléklete Erdély Miklósról. 1991. október 26. Új folyam II. évf. 43. sz. 6. o.; Szőke Annamária: Erdély Miklós müveinek restaurálása és rekonstrukciója. In: Magyar Mühely. 1999. XXXVII. évf. 110-111. sz. 130-132. o.; Beke László: Erdély Miklós munkássága. Krono-logikai vázlat képekkel 1985-ig. In: Erdély Miklós. Kiállítási katalógus, Óbuda Galéria, Zichy Kastély, 1986. április 11. - május 5. 24. o.; http://www.artpool.hu/Erdely/mutargy/Stabilizacio.html; 2013. 04. 23.] Lengyelországban 1980. augusztus 14-én sztrájk kezdődött a gdański Lenin Hajógyárban, melyet az egész országra kiterjedő megmozdulások követtek. Néhány nap alatt több mint 300 üzem csatlakozott a hajógyárban megalakult, Lech Wałęsa által vezetett Üzemközi Sztrájkbizottsághoz, melyből őszre létrejött a Szolidaritás Független Önkormányzó Szakszervezet. 1981 elejétől elapadt az élelmiszerellátás, kiürültek az üzletek polcai, s nyárra a kígyózó sorok már csak jegyrendszerben vásárolhattak. Ekkorra a Wałęsa vezette Szolidaritás már csaknem tizmillósra duzzadt. A fellobbanó indulatokat már nem tudta lecsitítani a pártállam, a gazdasági és politikai válság elmélyült, majd december 31-én bevezették a válságállapotot. A Kényes egyensúly (Veszély) címü munkáját 1981 novemberében Krakkóban, a Pawilon Wystawowyban, a IX. Cracow Meeting keretében állította fel Erdély. A Rágalomkristályokhoz hasonló struktúrájú, élükkel és lapjukkal egymásnak támasztott üveglapokból épített kártyavárszerü labirintust, de a korábbinál jóval nagyobb méretben és más tartalommal. Miközben a lapok kényes egyensúlyát egyenként stabilizálva felépítette a formációt, a publikum fokról-fokra kiszorult a kiállítótérből. Így végképp megközelíthetetlenné vált a labirintusban létrehozott két négyzetes vitrin, illetve a vitrinek tartalma: egy, a plafonról belógatott vöröskáposzta és egy indigópapírba csomagolt üveg vodka vagy bor. [Enyedi Ildikó, aki Krakkóban segített Erdélynek az építkezésben, vodkára emlékszik, Beke László viszont egy palack borról ír. Ami biztos, a visszaemlékezések szerint ebben az időben Krakkóban nemigen lehetett mást kapni, csak káposztát és alkoholt, s a jegyrendszer bevezetése után már ezekhez sem lehetett egykönnyen hozzájutni. Lásd még: Szőke Annamária: Erdély Miklós műveinek restaurálása és rekonstrukciója. In: Magyar Mühely. 
Erdély Miklós a Beke László által szervezett Posztkonceptuális tendenciák időtartama alatt megtartott Optimista elöadásban szintén a poszt- prefixummal jelzi a változásokat: a konceptuális müvészet idejétmúltságáról beszél és az egész poszt-neoavantgárd elvékonyodó tremolójáról. Erdély előadása mindezt, a '80-as évekre kifulladó reményeket, a tompuló életérzést, a megülepedett bornírtságot próbálja mégis átfordítani optimizmusba - egy másfajta poszt-ot szánva az új évtizednek -, mellyel megfogalmazza a poszt-neoavantgárd magatartás jellemzőit. A „Kemény és lágy” Posztkonceptuális tendenciákon pedig mintha az itt pontokba szedett táguló felelősségtudat, a müvészet társadalmi szerepvállalásának igénye kapott volna friss lendületet az Erdély körüli fiatalokkal találkozva. Az INDIGO csoport Ideiglenes szobor vattából címủ installációja egy vattából felépített, a kiállítási tér mennyezetéig feltörő atombombafelhő volt. A csoport szinte szó szerint vette a kiállítás címét: a fiatalok könnyed álnaivitásával nyúltak a politikai propagandában felszínen (és kordában) tartott téma brutális súlyához. Munkájuk egyszerre volt kemény és lágy, brutális és puha, recens, aktuális talajon álló és mégis múlékony, ideiglenes. A kiállítás katalógusába az installáció gondolati-formai kontextusát bemutató összeállítás került: a csoport már 1980 legelejétől datált, a kiállítást tervező rajzai, Iposteguy gombafelhő formájához hasonlatos Agyvelö címü szobrának a fotója és egy, lombjait a magasban szétterítő akácia képe. A képösszeállításon és a csoport ide köthető akcióin túl az installáció szövegszerü környezetét pedig

1999. XXXVII. évf. 110-111. sz. 133-137. o.; Beke László: Erdély Miklós munkássága. Krono-logikai vázlat képekkel 1985-ig. In: Erdély Miklós. Kiállítási katalógus, Óbuda Galéria, Zichy Kastély, 1986. április 11. - május 5. 25. o.; http://www.artpool.hu/Erdely/mutargy/Veszely.html; 2013. 04. 23.] 
az INDIGO neve alatt sokszorosított és terjesztett Indigo-békefelhívás, valamint az Önkéntes Törvényhozó Testület Alapítólevele adja. Az Indigobékefelhívást a csoport közös ötletei alapján Erdély Miklós szövegezte meg 1982-ben. Néhány részlete: „Olyan döntés meghozatala, amely totális pusztulással fenyeget, a szó legteljesebb értelmében tilos. [...] [M]inden olyan, bármennyire kicsiny tett, ami végtelen nagy kár megelőzését célozza, eszmei értelemben szintén végtelen nagy értékü." ${ }^{, 78}$ És az első pontok az Alapítólevélből, melyet az indigósok a '82-es párizsi Fiatal Müvészek Biennáléjára írtak: „1. A Testület rendelkezési jogköre korlátlan. 2. Rendelkezéseink hatálya mindenre és mindenkire, személyre, tárgyra és intézményekre egyaránt kiterjed, kötelező érvényü, és el nem évülő. 3. A Testület illetékessége vonatkozik minden olyan jelenségre, ami megváltoztatható, és arra is, ami nem megváltoztatható. 4. Végrehajtó hatalma illetékességével fordítottan arányos; így értelemszerủen nulla."79

Az Indigo-békefelhívásban és az Alapítólevél mondataiban is jól hallhatóan visszacsengenek Erdély Miklós gondolatai a poszt-neoavantgárd magatartás jellemzőiről, melyeknek biztató jelenlétére Erdély Dániel úgy emlékszik: „Miközben Papacs [Erdély Miklós] az új mütermében egyre többet foglalkozott a »tiszta szépség« problémáival, megvalósulási lehetőségeivel, a fiataloknak nagyobb társadalmi aktivitást javasolt, amelynek szívesen adott ideológiai hátteret, ötleteket és bármilyen más támogatást.” ${ }^{80}$ Ugyanakkor sorolhatjuk Erdély Miklós ebbe az irányba tartó

${ }^{78} \mathrm{Az}$ Országos Béketanács és az Indigo csoport Nemzetközi Képzőmüvészeti Pályázatot hirdet a nukleáris veszélyeztetettség tárgyában. In: KGYFI. 385. o.

${ }^{79}$ Önkéntes Törvényhozó Testület Alapítólevele (1982. szeptember). In: KGYFI. 386. o.

${ }^{80}$ Az idézet Erdély Dániel egy e-leveléből származik. A levelet és egyben az Ideiglenes szobor legbővebb értelmezését lásd: Szőke Annamária - Erdély 
korábbi törekvéseit. Az 1971-es akció-felolvasását a Szabadságot Angela Davisnek szolidaritási esten, ahol a bebörtönzött Marcuse-tanítvánnyal közösséget vállalva olvasta fel A nöi gonoszságról címü írását, miközben egy tányér levesbe lógatta nyakkendőjét, hogy a kapilláriscsöveken a nyakára tekert hurok felé szivárogjon fel a folyadék. ${ }^{81}$ Említenünk kell a Párizsi Biennálén 1971-ben kiállított Hír a forradalomról címü installációját, a felvételről lejátszott fülsiketítő csörömpölést és az üveglappal fedett porcelánkészlet fölé helyezett vasgolyót, amely, úgy tűnt, egy ferde hullámlemez tetejéről bármely pillanatban a törékeny

Dániel: Az Indigo csoport és a „társadalmi visszásságok”. In: KGYFI. 367-383. o. Erdély Dániel a Dialógus békecsoport kapcsán ír még hasonlókat: „Apám teljes mértékben tisztában volt a dolog jelenőségével. Még 1981 végén [1982-ben] megfogalmazta az Indigó csoport békefelhívását, melynek alapgondolata az emberek illetékességének hangsúlyozása volt. Azt mondta, hogy az akciókban nem vesz részt, szerinte mi jól csináljuk.” [Erdély Dániel: „Mi kis” életünk. In: Árgus. 1992. március-április, III. évf. 2. sz. 63. o. Ezúton is köszönöm Erdély Dániel biztató segítségét és a szöveg egészére kiterjedő megjegyzéseit. Erdély Miklósnak a Magyar Képzőművészeti Főiskolán megtartott, a fiatalok '75-76-os főiskolai mozgolódásaira biztatólag ható előadásairól lásd még: Halász András: Közvetítés pohárban. In: Magyar Mühely. 1983. július, XXI. évf. 67. sz. 41. o.]

${ }^{81}$ Szabadságot Angela Davisnek. Szolidaritási est. Eötvös Klub, Budapest, 1971. március 29. [Felolvasások, akciók: Balaskó Jenő, Erdély Miklós, Szentjóby Tamás és Rajczy Margit.] Lásd: Itt fü terem. Marno János és Antal István beszélgetése Szentjóby Tamás költészetéről és még sok minden másról. In: Holmi. 1990. szeptember, II. évf. 9. sz. 1026. o.; Erdély Dániel: „Mi kis” életünk. In: Árgus. 1991. szeptember-október, II. évf. 5. sz. 94. o.; Beke László: Erdély Miklós munkássága. Krono-logikai vázlat képekkel 1985-ig. In: Erdély Miklós. Kiállítási katalógus, Óbuda Galéria, Zichy Kastély, 1986. április 11. - május 5. 8. o.; Eörsi István: A besúgójelentés mint kultúrtörténeti forrásmunka. In: Élet és Irodalom. 2002. november 22. 8. o.; Békés Izabella: St. Auby Tamás, a nem művészet művésze. In: Bárka. 2010. XVIII. évf. 4. sz. 81. o. A felolvasott szöveget lásd: http://www.artpool.hu/Erdely/mutargy/A noi_gonoszsagrol.html; 2013. 04. 23. 
(csend)életre gurulhat. ${ }^{82}$ Vagy az ugyancsak 1971-es müncheni Kunstzonén végrehajtott Magánrendörség és büntetőakciót, mikor is tiltó feliratokat helyezett el a járókelők között - „Itt megbotlani tilos”, „Itt álldogálni tilos”, „Itt átkelni tilos”, „Itt mosolyogni tilos”, „Itt hangosan beszélni tilos”, Stb. -, majd pénzbírsággal büntette a szabályszegőket. ${ }^{83}$ És az 1971es Zászló-akciót a hollandiabeli Vaeshartelt-ban, a Mikes Kelemen Kör rendezvényén, amikor magyar zászlót terítettek a bejárati ajtó küszöbéhez, provokálva és állásfoglalásra késztetve az érkező disszidenseket: énekeltek, táncoltak, verekedtek rajta, majd a megtaposott zászlót egy dézsában kimosták, kivasalták és visszatűzték a helyére. ${ }^{84}$ De idézhetjük a varsói

${ }^{82}$ Bele László: Erdély Miklós munkássága. Krono-logikai vázlat képekkel 1985ig. In: Erdély Miklós. Kiállítási katalógus, Óbuda Galéria, Zichy Kastély, 1986. április 11. - május 5. 9. o.

${ }^{83}$ Beke László: Erdély Miklós munkássága. Krono-logikai vázlat képekkel 1985ig. In: Erdély Miklós. Kiállítási katalógus, Óbuda Galéria, Zichy Kastély, 1986. április 11. - május 5. 8-9. o.; Szőke Annamária: piros fehér zöld. In: Sub minervae nationis praesidio. Tanulmányok a nemzeti kultúra kérdésköréböl Németh Lajos 60. születésnapjára. Az ELTE és az ELTE Müvészettörténeti Tanszék közös kiadása, Budapest, 1989. 333-340. o. Képekkel kibővített variánsa az interneten: http://arthist.elte.hu/Tanarok/SzoekeA/fulltexts/PFZ.htm; 2013. 04. 25.; http://artpool.hu/Erdely/mutargy/Munchen.html; 2013. 04. 25.

84 A spontán történésekbe átfolyó akció menete nem tisztázott, a visszaemlékezések némileg eltérnek egymástól. Erdély úgy említi röviden Peternák Miklósnak, hogy Disszidensek táncoltatása a magyar zászlón. Az akcióról talán Nagy Pál számol be a legrészletesebben: „1971-ben a hollandiai Mikes Kelemen Kör összejövetelén is együtt voltunk, s együtt mutattuk be azt a zászlós akciót, amely kisebb botrányba fulladt. A Vaeshartelt-i - általunk csak Vashartyánnak becézett - konferenciaközpont zászlórúdjainak egyikére, tiszteletünkre, felhúzták a magyar lobogót is. Ezt eresztettük-szedtük le, mi műhelyesek, Erdély Miklós vezetésével. Énekelve vittük be a konferenciaterembe, ahol először jól megtapostuk (mint a történelem Magyarországot), majd táncoltunk rajta, széttépett Mühely-lapokkal szórtuk tele (hadd nőjön!), végül egy 
Foksal Galériában 1972-ben kiállított Morálalgebra. Szolidaritási akció tablóinak szájról szájra terjedő, vészjelző hálózattervét is: „Ha mindenki csak két embert jelöl meg minden intézményes és tömegkommunikációs eszköz mellőzésével, a világon rövid idő alatt mindenki értesíthető, és az emberek képesek közösen védekezni. A szolidaritás szirénapróbája egy adott időpontban végigfut a világon.” ${ }^{85}$ Már kifejezetten az

dézsában - némi késéssel - kimostuk, majd kivasaltuk: közben ugyanis Karátson Endre, aki nem nézhette tovább a háromszínü zászló megszentségtelenítését, nekiugrott Papp Tibornak, s csúnyán összeverekedtek, a földön birkóztak. A zászló végül újjászületett, s a verekedő partnerek is kibékültek azóta.” [Nagy Pál: Erdély Miklós: Tézisek az 1980-as marly-i konferenciához. In: Magyar Mühely. 1999. XXXVII. évf. 110-111. sz. 17. o. Lásd még: Beke László: Erdély Miklós munkássága. Krono-logikai vázlat képekkel 1985-ig. In: Erdély Miklós. Kiállítási katalógus, Óbuda Galéria, Zichy Kastély, 1986. április 11. - május 5. 8. o.; Szőke Annamária: piros fehér zöld. In: Sub minervae nationis praesidio. Tanulmányok a nemzeti kultúra kérdésköréböl Németh Lajos 60. születésnapjára. Az ELTE és az ELTE Müvészettörténeti Tanszék közös kiadása, Budapest, 1989. 333-340. o. Képekkel kibővített variánsa az interneten: http://arthist.elte.hu/Tanarok/SzoekeA/fulltexts/PFZ.htm; 2013. 04. 25.; http://artpool.hu/Erdely/mutargy/Munchen.html; 2013. 04. 25.; Szkárosi Endre: A Magyar Műhely szerepe a magyar performanszkultúra alakításában - az Artpool dokumentumainak tükrében. In: Magyar Mühely. 1012/3. sz. L. évf. 161. sz. 59. o.]

${ }^{85}$ A Morálalgebra nem csak a szolidaritás hálózattervét számszerüsíti: a munka egésze az egymással ellentétes irányba tartó érintkezés-sorozatok kollázsa. Erdély öt faliújság-szerủ kollázs-tablót állított ki, újságokból kivágott képekkel, fotókkal, különféle cetlikkel, jegyzetekkel és számításokkal. Két feltüzött lapon az az ábra látható, amelyet a Pioneer-10 és a Pioneer-11 ürszondák aranyozott alumíniumtáblán vittek magukkal a Naprendszeren kívülre, a távoli érintkezést, a Földön kívüli kommunikáció minimumát lehetővé téve. A tablósorozat többi részén pedig az érintkezés földi, számításokkal levezetett, egymással ellentétes irányú sorozatai láthatóak: a kambodzsai fejvadász levágott fejeket lógató fotója mellett egy újszülöttet tartó orvos képe szerepel, a fentebb idézett „szolidaritás szirénapróbája” pedig a gyilkolás kimért, még önmagát is felszámoló logikája 
ellen fut végig a világon. „Az öldöklés logikája szerint, ha mindenki átlagban két embert öl meg, 32 lépésben az egész emberiség kipusztítható, tekintve, hogy egy ember kétszer nem ölhető meg." A hatékony pusztítás megtervezhető, a gyilkolás mechanizmusának gördülékenysége mindössze a szervezettségen múlik, ahogy a védekezés is pontosan kiszámolható, majd jelölésekkel kitűnően koordinálható: a tervezőasztal fölött álló racionalitás nagyszerüsége csak a morállal nem tud elszámolni. Erdély az öt tabló közül az utolsót letakarta, s a tárlatlátogatóknak a tablót takaró textília alá kellett benyúlniuk, hogy kitapogassák a Szolidaritási akció dátumát. Az ésszerű számítások egymásnak ütköző montázsa és az érintkezés-sorozatokat, jelöléseket illusztráló fotók itt csaphattak át új minőségbe. A „halott számok” egymást kioltó sorozata után a látogatók a vak tapogatózásban sejthették meg azt, hogy ha még nem is látják (be), van, és egyszer el is jön az ideje a mindent átölelő szolidaritásnak. Ahogy az egyik cetlin szerepel: „MINDENKI, MINDENÜTT, EGYSZERRE.” És persze, a letakart dátumot sorjában, egymás után megérintve egyszersmind részeseivé válhattak a vészjelző hálózatterv érintéssel történő terjedésének. Pontosan úgy, ahogy a Szolidaritási akció utolsó pontja szól: „A statisztika halott számait töltsük meg élettel.” [Anik Cs. Asztalos [Körner Éva]: No isms in Hungary. In: Studio International. 1974. March, Vol. 187. No. 964. 110-111. o.; Beke László: KENTAUR. In: Magyar Mühely. 1978. június, XVI. évf. 54-55. sz. 76. o., 84. o. Újraközölve: In: Mozgó Film 2. A BBS Mühelykiadványa. Szerk. Forgács Péter. A „K” rovatot szerkesztette: Beke László. Balázs Béla Stúdió, Budapest, 1986. 217. o., 230. o.; Beke László: Erdély Miklós munkássága. Krono-logikai vázlat képekkel 1985-ig. In: Erdély Miklós. Kiállítási katalógus, Óbuda Galéria, Zichy Kastély, 1986. április 11. - május 5. 9-10. o.; Kurdy Fehér János: Kamillába mártott vatta. (Beke László Erdély Miklósról). In: Tiszatáj. 1992. XLVI. évf. 5. sz. 93-94. o.; Beke László: Erdély Miklós és a müvészettörténet. Az MKE Intermédia Tanszékén az Erdély Miklós Alapítvány által szervezett Erdély 80|80 címü szemináriumon elhangzott előadás. (2008. június 6.) Interneten: http://catalog.c3.hu/index.php?page=work\&id=49\&lang=HU; $\quad 2013 . \quad 04 . \quad 05 . ;$ Perneczky Géza: Erdély Miklós, és mủve, a dekonstruktív tautológia. In: Erdély Miklós /1928-1986/. Kiállítási katalógus, Csók István Képtár, István Király Múzeum, Székesfehérvár, 1991. október 26. - december 31. 19. o.; Szőke Annamária: „Titok a jövő jelenléte”. Tudomány a mủvészet határain belül Erdély Miklós művészetében. In: Né/ma? Tanulmányok a magyar neoavantgárd köréböl. Szerkesztette Deréky Pál és Müllner András. Ráció Kiadó, Budapest, 2004. 257. 
atomfenyegetéshez közelítve elolvashatjuk Erdély 1975-ben megjelent írását Iposteguy szobráról, ${ }^{86}$ de akár az 1978-ban publikált Mit keres Einstein a tengerparton? címü esszéjét is:

Einstein kisétált a tengerpartra; az emberi agy teljesítőképességeinek határaihoz. A ráció azonban, úgy látszik, nem nyújt védelmet, mintha semmi kapcsolata nem lenne az emberi élet biztosításával. A történelem menetének lényegén nem változtat, hogy az ember gondolkodó lény; a háborúk úgy folynak, mint a hangyáknál, csak - hála a kiváló technikának - kényelmesebben és hatékonyabban. [...] A természetes kiválasztás vált természetellenessé azáltal, hogy immár az emberi faj fennmaradását nem valamely életképesebb faj megjelenése veszélyezteti, hanem önmaga. [...] Ha az ember öngyilkos állatnak bizonyul, azért kizárólag túlfejlett agyveleje a felelős. ${ }^{87}$

Erdély Miklós a finomabb grafikák, indigórajzok mellett az 1980as évektől a montázs egy más irányú továbbfejlesztéseként anyagkollázsok, egyfajta kicsinyített installációk és erőteljesebb bitumenképek készítésébe kezdett, nyersebb matériákat helyezve egymás mellé, egymásra és egymásba. Ekkor készült a Jeremiáda, a Sokasodjatok, az Autópályáról

o.; Szőke Annamária: Az Erdély Miklós-hagyaték. Az MKE Intermédia Tanszékén az Erdély Miklós Alapítvány által szervezett Erdély $80 \mid 80$ címủ szemináriumon elhangzott előadás. (2008. június 5.) Interneten: http://catalog.c3.hu/index.php?page=work\&id=38\&lang=HU; 2013. 04. 05. A Morálalgebra az 1972-es varsói kiállítás után 1974-ben, Buenos Airesben volt látható: a Vanguardia Húngara címü tárlaton szerepelt, melyet a Centro de Arte y Comunicación szervezett. Ekkor bővült a munka az ürszondák ábráival, és ekkor keletkezett a Szolidaritási akció címen fennmaradt kézirat. Lásd: Erdély Miklós: Szolidaritási akció. Interneten: http://labor.c3.hu/erdely-miklos-szolidaritasakcio/; 2013. 04. 05.]

${ }^{86}$ Erdély Miklós: Miért nem szép Iposteguy Agyveleje? In: MI. 60-66. o.

${ }^{87}$ Erdély Miklós: Mit keres Einstein a tengerparton? In: MI. 54-55. o. 
a túlvilágra, a Sebek és bünök, a Koll-montázs, a Szigetelöpapír, indigópapír, ragasztópapír, a Másik rózsa, a Papacs!, az Enyészpont, az Armageddon-képek, és 1980 körül festette az Acsás - értsd: atomcsapás című bitumenképet is, papír, bitumen, üveg és drót felhasználásával. Az 1977-es első environmentjét, a Bújtatott zöldet 1979-től 15-20 darabból álló mủcsoport követte. Az 1980-ban készített nagyszabású installációi, érett environmentjei pedig olyan anyagokból épültek fel - ólomból, maceszból, kátránypapírból, szurokból, üvegből, telexpapírból - melyek a kezei alatt már dús szimbolikával bírtak, ugyanakkor a szimbólumok interakciója minduntalan felfedte az egymásra támaszkodó, látható, tapintható, szagolható tárgyiságot, a pöre matériát is. A felhasznált anyagok a nyitottság állapotában egyensúlyoztak, félúton a csupasz tárgyiság és a hétköznapok aktualitásán is jóval távolabbra mutató szimbolikus tartalmak között. Ekkor készült a Borisz Godunov, A kalcedoni zsinat emlékére, a Südstrand (Horizont nélkül) és a Stabilizáció.

Erdély 1980-tól színpadképeket is tervezett Pauer Gyulával a kaposvári Csiky Gergely Színházban. Ascher Tamás rendezésében előbb John Arden Élnek, mint a disznók (Gyöngyélet) ${ }^{88}$ címü darabját vitték színre, majd 1981-ben - a Posztkonceptuális tendenciák évében - J. SZ. Turgenyev Egy hónap falun című darabját. ${ }^{89}$ Pauer és Erdély hol jobban, hol kevésbé elkülönülő munkamegosztásban dolgoztak. Az Egy hónap falun jelmezeit Pauer Gyula készítette, Erdély Miklós pedig a díszleteket tervezte és valósította meg, a rá nagyon is jellemző anyaghasználattal, festékport, kátrányt, parafát, tüllt, eternitcsövet felhasználva. Fehér tüllre csorgatott szurokból a plafonon szétterülő atombombafelhöhöz hasonló

\footnotetext{
${ }^{88}$ Bemutató: 1980. február 22.

${ }^{89}$ Bemutató: 1981. október 2.
} 
szuffitasort állított össze, súlyos, veszélyeztetett atmoszférába burkolva a darabot. S némi véletlen folytán a szuffitasor még a maghasadás utáni folyamatokat is bemutatta. Egy atomrobbanásban felszabaduló irtózatos hő hatására ugyanis a hipocentrumban minden víz pillanatok alatt elpárolog, majd a gombafelhővel együtt a magasba emelkedik, egészen addig a hideg légtérig, ahol kicsapódik, s a felszállt apró részecskékkel keveredve fekete eső formájában visszahull a földre, beterítve a még fel nem perzselt életet is. A díszlet épp csak a premierre készült el, s ott derült ki, hogy a reflektorok hőjében a szurok megolvad. A magasban gomolygó szuffitasorból fekete eső kezdett csöpögni, lassan, kitartóan, a földre, a fóliába csomagolt bútorokra és a szereplők nyakába. ${ }^{90}$

90 Ascher Tamás visszaemlékezésében a szuffitasor mellett a klasszikus, ám fóliába csomagolt bútorok rideg csillogását emeli ki, mely számára ugyan szokatlan ötletnek tủnt, de éppen ezáltal tudta úgy elgondolni Turgenyev darabját, mintha az Ördögök folytatása lenne, mintha a Dosztojevszkij-Wajda dráma még a falun sem érne véget. [Színház- és filmrendezők Pauer Gyuláról. Ascher Tamás. A beszélgetéseket készítette és lejegyzetelte Antal István. In: Pauer. Összeáll. Szőke Annamária. Szerk. Szőke Annamária, Beke László. MTA Mủvészettörténeti Kutatóintézet, Budapest, 2005. 357. o.] A kritikusokból különböző reakciókat váltott ki a színpadkép. Ki így, ki úgy, de többnyire erős szavakkal írtak róla. Mészáros Tamás: „Essünk túl a nehezén; mert a nézőnek is ezt kell tennie, amikor meglátja Erdély Miklós otromba díszletét, ezt a meglehetősen taszító, ki tudja mit [...].” [Mészáros Tamás: Kitörési kísérlet visszafelé. Turgenyev-bemutató Kaposvárott. In: Magyar Hírlap. 1981. november 7. XIV. évf. 262. sz. 10. o.] Csáki Judit: „Színvonalas a díszlet - Erdély Miklós munkája -, jól ironizálják a kopottas csillogást, a műeleganciát a fóliába csomagolt bútorok. [Csáki Judit: Színészparádé Kaposvárott. Turgenyev: Egy hónap falun. In: Népszava. 1981. október 29. CIX. évf. 254. sz. 6. o.] Bulla Károly: „Erdély Miklós díszlete ezúttal a fekete módozatait kóstoltatja, a különböző fóliák csillogásával egyesítve. Sikerült játéktér, mely méltó közeget biztosít e kitűnő előadásnak.” [Bulla Károly: Egy hónap falun. In: Film Színház Muzsika. 1981. október 17. XXX. évf. 42. sz. 10. o.] Ahogy pedig Erdély 1982- 
ben mondja: „Általános díszlettervezői elvem - én még kezdő vagyok, de már ennyit elmondhatok -, hogy kétféle díszletet nem csinálok: olyat, ami teljesen oda való, és olyat, ami egyáltalán nem való oda. Azt hiszem, fordított sorrendben kellett volna mondanom.” [Beke László: Milyen ne legyen a Hrabal-darab színpadképe? In: Mozgó Világ. 1982/7. sz. 60-61. o.]

Pauer Gyula és Erdély Miklós nem csak időben álltak közel egymáshoz. Pauer Gyula Ascher Tamással együtt egy időre Erdélynél laktak mint albérlők. S persze itt sem csak a tér kötötte őket össze: a közös, hosszúra nyúló esti beszélgetések eredménye több darab színrevitele lett. Pauer és Erdély kapcsolata azonban jóval messzebbre nyúlik vissza: a ’70-es évek elejéig, a Galántai György által életre hívott balatonboglári kápolnatárlatok sűrủ, kivételes, ámde rövid három nyaráig. A balatonboglári kápolnáig, ahol három éven át tudtak összegyülni az indexre tett, többségében a türt és a tiltott kategóriába tartozó progresszív müvészek. Olyanok, akik a támogatott müvészeti életből kiszorultak, avagy abból inkább nem is kértek. De sorolhatjuk a kettejüket összekötő munkákat is. Alkotói kapcsolatukat láthatjuk Erdély Verzió (1979) és Tavaszi kivégzés (1985) című filmjeiben, melyekben Pauer színészként - azaz pszeudolényként - szerepel. És említhetjük Pauer Gyulának a hatvani, 1976-os Expozíció - Fotó/müvészet kiállításon szerepelő Doboz, benne tíz fénykép címü kollázssorozatát is, ugyanis ennek az utolsó darabja Erdélyt idézi. A rajta szereplő cím Álomrekonstrukció, az alatta lévő szöveg pedig a következő: „Álmomban csíkos arccal fölfelé néztél, fátyol volt fejeden és egy porcelánkutya volt kezedben.” [Expozíció. Fotó/müvészet. Kiállítási katalógus, Hatvany Lajos Múzeum, Hatvan, 1976. október 24. - 1977. január 31. A Hatvany Lajos Múzeum Füzetei No 2., MÉM STAGEK sokszorosító 367/76. o.n. A kollázssorozatról lásd: Szilágyi Sándor: Neoavantgárd tendenciák a magyar fotómüvészetben 1965-1984. Fotókultúra - Új Mandátum Könyvkiadó, Budapest, 2007. 330. o. A Tíz fénykép Pauer életművén belüli szerepéről pedig lásd: Beke László: Konceptuális művek és szöveghasználat, fotó, film, videó az 1970-es években. In: Pauer. Összeáll.

Szőke Annamária. Szerk. Szőke Annamária, Beke László. MTA Múvészettörténeti Kutatóintézet, Budapest, 2005. 64. o.] Pauer ezzel Erdélynek legalább két munkájára utal: az 1977-es Álommásolatokra és az Antiszempont címü hangjátékra, illetve filmre, melynek szövege 1974-ben jelent meg a Kollapszus orv. című kötetben. Ebből idézek: „NAGYTESTÜ PRÉMES ÁLLATOT LÁTTAM HÁTULRÓL. FEJE KÉNYELMETLENÜL BALRA FELFELE CSAVARVA, AMINT AZ ESTHAJNALCSILLAGOT NÉZTE 
MEREVEN. AZONBAN FÉNYTELEN ORRHEGYE NEM VOLT VALÓDI, SEM A PRÉMJE, SEM AZ ÁLLAT, SEM AZ ESTHAJNALCSILLAG NEM VOLT VALÓDI. CSAK A KÉNYELMETLENSÉG VOLT VALÓDI. CSAK A KÉNYELMETLENSÉG - AZ VOLT VALÓDI.” [Erdély Miklós: Antiszempont. In: KO. 78. o.] Itt felidézhetjük, hogy az anekdota szerint ezt olvasta fel Erdély a Virágárok utcai házának kertjében, mikor az asztaltársaságból Tandori - akivel egyszerre, megosztva kaptak 1974-ben Kassák-díjat - felpattant, és azt hadarta izgatottan: „Ez az! Így kell ismételni! Ez az igazi költészet!” [A legendát többek között Petőcz András idézi fel, de legalábbis életben tartja Müllner András is. Petőcz András: Jegyzet Erdély Miklósról. In: Holmi. 1990. szeptember, II. évf. 9. sz. 1039-1040. o. Újraközölve: In: Uő: A jelben-létezés méltósága. írások, 19821990. Colosseum, Budapest, 1990. 114-115. o.; Müllner András: Nagytestű prémes állatok. Néhány szó Tandoriról és Erdélyről egy recenzió keretében. In: Fogaras György - Müllner András: Rátévedések - a romantikában, a neoavantgárdban és más területeken. Ictus Kiadó és JATE Irodalomelmélet Csoport, Szeged, 1998. 133-134. o. Kukorelly Endre pedig, aki szerint „a neoavantgárd nélkül nincs meg a posztmodern”, és ennek a korszaknak az egyik irodalmi csúcsteljesítménye Erdély Kollapszus orv. címü kötete, s Erdély Miklós maga nem más, mint a „magyar neoavantgárd pápája, nagyjából Joseph Beuys magasságában”, tehát Kukorelly Endre pedig a következőket teszi hozzá a Pauer által is megidézett vershez, és persze Erdély legendájához: „Szerintem csak Thomas Bernhard ismétel így. De ő sokszor ismétel, itt viszont csak 1 x van, attól ilyen pokolian erős.” Kukorelly Endre: 666 999 000 . Előbb némi szívdobogás, kissé zajos, rendben, tehát: valamit a magyar irodalomról. Monológ. ${ }_{00}$. In: 2000. MM április, 12. évf. 4. sz. 52-72. o.]

Pauer és Erdély közös történetének végpontja pedig Pauer visszaemlékezése Erdély távozását követően 12 évvel: „Tavaszi Virágárok utcán árnyékos napsütésben szuszog lefelé a Pasaréti út felé, kilenc féltíz tizenegy körül, a járás gyönyörét magyarázza, lábai boldogságát, a lejtőnek örül. | Hova tűnt el, hova tünt el, öreg haver hova tüntél | Szégyellem, hogy nem találok közös fényképeket, évek a »Sodrásban«, minden nap más, minden más, kollapszus orv, esti felolvasás, más a fonyódi ősliget, a szerelem, álomemlékezet. | Hova tűntél, hova tüntél, öreg haver hova tűnt el | Hatalmas búra alatt kozmikus éjszaka, villanykörte világít, ülünk kertjében csendesen, a család, a barátok, Körner, Ascher s a többiek, sokan mások, Érmezei már elment, várunk türelmesen | Hova tüntél, hova tüntél, öreg haver hova tűntél | Egyszer jött fel hozzám az 
Az 1981-es éven túllendülve 1984-ben, Bécsben, az Orwellkiállításon kell még feltétlenül megállnunk. Itt mutatta be Erdély a Hadititok címü, talán legismertebb installációját. ${ }^{91}$ Mindig is különös módon foglalkoztatták a titkok: az ismeretelmélet csak megsejthető titkai, a tapasztalat és a gondolat, a tudomány és a művészet határain túl felsejlő titok, valamint a titok mint tiltás, a szellemi energiák elrejtése, az információk, gondolatok titkosítása, a tudás hatalmi, hadiipari kisajátítása. A titokról címü írásában biblikus konnotáció kapcsolja össze a titkot a tiltással: „A titok az emberiséggel egyidős fogalom és kezdetektől a tilossal függött össze. [...] A tiltás már eleve jelezte, hogy az ember szabad, hiszen a lehetetlent fölösleges megtiltani.”92 Saját életművében az információk korlátozása elleni fellépés kezdetét a ’70-es évek első felére teszi, melynek nyitánya az 1971-es CETI konferencia híre. ${ }^{93}$ Az 1981-es Optimista elöadásban is beszél a CETI-ről, majd a természettudományos felfedezések

Egyetem térre, rajta volt óriási posztóköpenye, két három négy méterről fogasra dobta kalapját - mütermemben ma is kísért lépteinek gyönyöre | Hova tünt el, hova tünt el, öreg haver hova tünt el” [Pauer Gyula: Erdély Miklósról 12 év után. In: Balkon. 1998/10. sz. 22. o. A „Sodrás”-ról, a Pauer Gyula, Erdély Miklós és Legéndy Péter által bérelt Sodrás utcai szuterén müteremlakásról lásd még: Legéndy Péter György: Semmi van. Emlékirat Erdély Miklósról. In: Hölgyfutár. Álom. Mamüvészeti Magazin. 1990. július-augusztus-szeptember, II. évf. 2. sz. 36-37. o.]

91 „1984” - Orwell und die Gegenwart. Museum des 20. Jahrhunderts, Bécs, 1984. május 5. - július 8. A munka elkészítését Bécsben Csutak Magdolna, Maurer Dóra és Reha György segítette. A Hadititok egy egyszerüsített változata ebben az évben az Ernst Múzeumban volt látható: Frissen festve. A magyar festészet új hulláma. Ernst Múzeum, Budapest, 1984. augusztus 24. - szeptember 30.

${ }^{92}$ Erdély Miklós: A titokról. In: Új Symposion. 1985/1-2. sz. 12. o.

${ }^{93}$ Az ön-genealogiát lásd: Peternák Miklós: Beszélgetés Erdély Miklóssal 1983 tavaszán. In: Árgus. 1991. szeptember-október, II. évf. 5. sz. 81. o. 
felszabadító hatásáról szólva megjegyzi: „A haditechnika szolgálatában a legfantasztikusabb kutatások teljes titokban folynak. A Hadititok a jogcím, amely az eredmények nyilvánosságra hozatalát megakadályozza. [...] Az új művészeteknél nélkülözhetetlen és betilthatatlan a nyitott gondolkodás, hogy ez a gondolkodás foszlányos, szervezetlen, el-akadó, nem öntudatos és nem elég leleményes, ezért megint csak az a bizonyos információzárlat a felelős; a lélek eltömése néhány bizonytalan cáfolat-cáfolatból készült rongydugóval.”94 Később azonban úgy folytatja: „A művészek alkotó energiái még nem tekinthetők teljesen állami monopóliumnak." ${ }^{95} \mathrm{~S}$ többek közt ez utóbbiban bízva zárja előadását mégiscsak optimistán: „Az információzárlatot az igény leleményessége valahogy meg fogja tudni kerülni, a lényegivel való érintkezés lehetőségére majd rátalál, és ami elévült, az valami új felismerés fényében, de legalábbis reményében veszti el érvényét." 96

Az először Bécsben kiállított Hadititok egy hatalmas, 3 x 4,6 méteres, színpadképszerü, festett installáció, melyen nagy, fekete betükkel szerepel a felirat: „KRIEGSGEHEIMNIS”. Építéséhez kátránypapírt, bitument, ponyvavásznat, üveget, lámpákat és villanyújságot használt fel. Többször ráfestette és krétával rárajzolta a Müller-Lyer-illúzió néven ismert, érzékcsalódást keltő ábrák variánsait, s jobboldalt három vörösen világító lámpát helyezett a paraván mögé. Középen fehérrel festett üvegtábla támaszkodott a vászonnak, átszakítva a felületet, srégen, a túloldalról erős fénnyel megvilágítva, baloldalt pedig a mübe applikált digitális kijelzőn vörös betűkkel futottak végig Erdély szövegének sorai. A

\footnotetext{
${ }^{94}$ Erdély Miklós: Optimista előadás. In: MI. 140-141. o.

${ }^{95}$ Uo. 141. o.

${ }^{96}$ Uo. 147. o.
} 
néző a csalfa optikai jelenségeken túli fénnyel nézhetett szembe, azzal, hogy a megcsalható tapasztalatokon, a könnyüszerrel kordában tartható ismereteken túl is van valami. A tiltó, megálljt parancsoló vörös lámpák és a háttérből érkező fény jelezték, hogy az igazi kérdések a paravánszerű mü „mögött” rejlenek. Hogy a kérdések semmiképp sem lehetnek egy bitumenben álló, átszakított ponyva felületén, hanem csakis a látható világ mögött. S a reményt a lényegivel való érintkezésre az üveglapon átáramló tiszta fény adhatta. Erdély a szokásától eltérően nem akcióval tette teljesebbé az installáció jelenés-terét. Az elégedettség, az elvakított életérzés, a reflex-szerü, irányított kíváncsiság és a mindenre kiterjedő hadititok közötti kapcsolatot egy felületre tömörítve a fogyasztói társadalom friss eszközén, villanyújságon futatta végig tételeit. A reklámszerűen felvillanó mondatok a hadititok mibenlétét sorolták:

1. Senki sem tudja, hogy mit nem tud - Hadititok

2. Senki sem tudja, hogy ki tudja - Hadititok

3. A hadititok sokkal fontosabb, mint aki ismeri

4. A hadititok az, amit nem tudni, hanem titkolni kell

5. Minden, ami fontos - Hadititok

6. Minden, ami hadititok - fontos

7. A hadititok fontosabb, mint amire vonatkozik

8. A hadititok fontosabb, mint aki ismeri

9. A hadititok az, amit tudni tilos

10. Minden fontos lehet

11. Semmit sem szabad tudni - Hadititok

12. Ki megbízható - Hadititok

13. Ki tudja, hogy ki a megbízható - Hadititok

14. Mindenhol, minden - Hadititok

15. Sehol senki nem tudja mi - Hadititok

16. A megismerhető - Hadititok

17. A megismerhetetlen - Hadititok

18. Ami van - Hadititok

19. Ami nincs - Hadititok

20. A vigasz - Hadititok

21. A lehetö - Hadititok

22. A lehetetlen - Hadititok 
23. Ami szent - Hadititok

24. Ami menthetetlen - Hadititok

25. Ami kijavítható - Hadititok

26. Ami visszavonhatatlan - Hadititok

27. A jövő - Hadititok

28. A múlt - Hadititok

29. A jelen - Hadititok $^{97}$

Erdély a kiállítás katalógusába a következő sorokat írta: „Jelen kiállításon kísérletet teszek arra, hogy felhívjam a figyelmet a hadiipar minden egyebet maga alá gyürő öntörvényü mechanizmusára. E jelenség tudatbeszűkítő, személyiségroncsoló következményei az ismeretlennel szemben álló emberi lény létének alapjait érintik. Úgy gondolom, hogy ez az 1984-es világhelyzet legfontosabb meghatározója.,98

97 Erdély kéziratos szövegét Szőke Annamária közli, lásd: Szőke Annamária: „Titok a jövő jelenléte”. Tudomány a művészet határain belül Erdély Miklós müvészetében. In: Né/ma? Tanulmányok a magyar neoavantgárd köréböl. Szerkesztette Deréky Pál és Müllner András. Ráció Kiadó, Budapest, 2004. 266267. o.

98 A magyarul kéziratban fennmaradt szöveget szintén Szőke Annamária közli, lásd: Uo. 265. o. Az installáción több helyen szereplö, Müller-Lyer-illúzió néven ismert ábrák variánsai az Új Élet - A Magyar Izraeliták Lapja egy kritikájának tanúsága szerint nem csupán a könnyüszerrel megcsalható érzékekre, a megvezethető és kordában tartható ismeretekre hívták fel a figyelmet, de nem is egyszerüen optikai csalódást generáltak: a gyanúval fürkésző tekintet döbbenetes félreértéseit és szituáltságát is felszínre hozták. Zsadányi Oszkár - és ha Erdély ismerte Zsadányi kritikáját, számára ez kölönösen fájdalmas lehetett horogkeresztet látott a munkán. Ahogy írja: „[T]aláltunk egy festményt, amely nem ábrázol mást, mint egy hatalmas horogkeresztet. Felette a reklámújsághoz hasonlóan kivilágított szavak és mondatok: »senki sem tudja, hogy mit hoz a jövő, ami ismeretlen.« Ez nem más, mint burkolt (?) propaganda a múlt legvéresebb korszakáról, és készítője, Erdély Miklós ezt a címet adta müvének: »Hadititok«." [(Zsadányi) [Zsadányi Oszkár]: Horogkereszt egy kiállításon. In: Új élet. 1984. október 15. XXXIX. évf. 20. sz. 4. o.] Szőke Annamária a Hadititok terét a mühöz készült vázlatok alapján Erdély Aranyfasisztáim címü versével társítja: 
„Apokaliptikus helyzet, amelynek a Hadititokhoz készült vázlatokon találjuk meg a képi megfelelőjét: a »színpad« nagy részét emberi alakok sziluettjei töltik ki, egy tömeg, amely a nyíláson át távozik. A versben is említett paraván van e túlvilág mögött, amelynek milyenségére vonatkozó igen érzékletes benyomást az szerezhet, aki a mü elkészítésében asszisztál. A felhasznált bitument olvadt állapotban kell ráönteni a kátránypapírra, s ekkor a bitumen leírhatatlanul vonzó szaga keveredik a forró anyag okozta elviselhetetlen füsttel.” [Uo. 269. o.] Mivel azonban a kiállított müre végül nem kerültek rá az emberi figurák, s mivel a vázlatokon még nem szerepelnek a Müller-Lyer-illúzió ábrái, az installációt talán teljesebb - némely értelmezőhöz és Erdélynek a katalógusba írt soraihoz hasonlóan - jóval tágabb, általános ismeretelméleti, illetve az akár aktualizálódni is képes politikai konnotációkra is nyitottnak látni. Megjegyezhetjük, Erdély még három, nagyjából ekkori munkájához használt villanyújságot: 1984-ben, a Plánum '84 fesztiválon kiállított In memoriam Réginé - korábbi, csupán anekdotaként fennmaradt címén Déryné, későbbi, végleges címén pedig Réginé I. - festménye alá helyezve, 1985-ben a Városligeti Műjégpályán a Műcsarnok által szervezett Hanglemez címü rendezvényen bemutatott akciója keretéül felépített installációban, valamint az 1985-ben forgatott Tavaszi kivégzés címü filmben, ahol is a panaszirodán éppen a kivégzés dátumának kiírása előtt romlik el a kijelző. A villanyújság használatának írott kontextusaként pedig érdemes elolvasnunk legalább néhány sort Erdély $A$ filmezés késői fiatalsága (Az underground filmmozgalom kialakulásának társadalmi háttere) címü tanulmányából: „Mindenképpen másképpen kell elkészíteni azt a kommersz filmet, amelyet egyszeri használatra szántak, akár egy papírzsebkendőt, mint az olyan autonóm mủvészi igényủ alkotást, ami osztozni kíván a tradicionális műfajok örökérvényüségében. Joggal jelentheti ki Stan Brakhage: »Az én filmjeimet egyszer megnézni olyan, mint Ezra Pound egyik Cantóját villanyújságon végigolvasni.«" [Erdély Miklós: A filmezés késői fiatalsága. (Az underground filmmozgalom kialakulásának társadalmi háttere). In: AF. 177. o. A Hadititokról lásd még: Sinkovits Péter: Képzuhatag. A magyar festészet új hullámai az Ernst Múzeumban. In: Müvészet. 1984/12. sz. 49. o.; Deréky Pál Wernitzer Júlia: Mủvészet és utópia a bécsi „1984”-kiállításon. In: Müvészet. 1985/1. sz. 41-44. o.; Beke László: Elektromosság és müvészet Magyarországon. In: Uö: MÉDIUM/ELMÉLET. Tanulmányok 1972-1992. Balassi Kiadó - BAE Tartóshullám - Intermédia, Budapest, 1997. 238. o.; Beke László: Erdély Miklós munkássága. Krono-logikai vázlat képekkel 1985-ig. In: Erdély Miklós. Kiállítási 
Most azonban már térjünk vissza a korszakoláshoz és a kategorizáláshoz. Ahhoz, hogy mennyiben lehet az időszak mára már stabilizálódott müvészettörténeti kategóriáival lefedni Erdély Miklós mediális kísérletezéseit. Erdély 1981-ben a „koncept art levitézlettségéről” beszél, Beke László pedig posztkonceptuális tendenciákról. Szintúgy 1981ben került sor a '80-as éveket szimbolikusan megnyitó Új szenzibilitás című kiállítás-sorozat első darabjára, melyet Hegyi Lóránd rendezett. ${ }^{99}$

katalógus, Óbuda Galéria, Zichy Kastély, 1986. április 11. - május 5. 27-28. o.; Szőke Annamária: piros fehér zöld. In: Sub minervae nationis praesidio. Tanulmányok a nemzeti kultúra kérdésköréböl Németh Lajos 60. születésnapjára. Az ELTE és az ELTE Művészettörténeti Tanszék közös kiadása, Budapest, 1989. 333-340. o. Képekkel kibővített variánsa az interneten: http://arthist.elte.hu/Tanarok/SzoekeA/fulltexts/PFZ.htm; 2013. $04 . \quad 25$. ; http://artpool.hu/Erdely/mutargy/Munchen.html; 2013. 04. 25.; Petőcz András: Jegyzet Erdély Miklósról. In: Holmi. 1990. szeptember, II. évf. 9. sz. 1041. o. Újraközölve: In: Uő: A jelben-létezés méltósága. írások, 1982-1990. Colosseum, Budapest, 1990. 116. o.; Szőke Annamária: Erdély Miklós műveinek restaurálása és rekonstrukciója. In: Magyar Mühely. 1999. XXXVII. évf. 110-111. sz. 123124. o.; György Péter: Erdély Miklós - A szelíd botrány müvésze. In: Holmi. 1992/8. sz. 1179. o.; Hornyik Sándor: Naiv realizmus és „természettudományos koncept". A modern természettudomány helye Erdély Miklós művészetében. In: Magyar Mühely. 2004. XLIII. évf. 131. sz. 44-46. o.; Hornyik Sándor: A fekete lyukak esztétikája. Kritikai teória és praxis Erdély Miklósnál. In: Balkon. 2006/6. sz. 7-8. o.; Peternák Miklós: Képháromszög. Ráció Kiadó, Budapest, 2007. 61. o., 102. o., 193. o.; Peternák Miklós: Kísérlet és kutatás a XX. századi magyar művészetben. Az intermediális technikától a komputerképig. In: Magyar Mühely. 1992. június, XXXI. évf. 84. sz. 40. o.; Peternák Miklós: Interdiszciplinaritás. Új médiumok az elmúlt három évtized magyar mủvészetében - vagy kire hatott Erdély Miklós és kire nem? In: A második nyilvánosság - XX. századi magyar müvészet. Összeállította Hans Knoll. Enciklopédia Kiadó, Budapest, 2002. 258259. o.; Reha György: A „müvészet bizony marhaság” - adalékok a Hadititokhoz. In: Artmagazin. 2014. XII. évf. 7. sz. 71. sz. 16-17. o.]

${ }^{99}$ Új szenzibilitás I. Fészek Galéria, Budapest, 1981. december 1-16. 
Hegyi avantgárddal és konceptualizmussal szembeforduló transzavantgárdelméletében az új szenzibilitás kategória azokat a magatartás- és szemléletmódokat jelöli, melyek legpregnánsabban az új festészetben öltöttek testet. ${ }^{100}$ A ’80-as évek tendenciáit utólag szemlélve Andrási Gábor pedig - mintegy a posztkonceptuális művészet jelenségeit kiemelve - az ’érzéki konceptualitás’ terminust vezeti be a recepcióba. Andrási 1993-ban megjelent A gondolat formái címü tanulmányában főként Henri Focillon teóriájára alapozva mutat rá a ’80-as évek Hegyi Lórándnál tágabban értelmezett szenzualitására, melybe már nem csupán az új festészeti tendenciák férnek bele, hanem a konceptuális müvészet módosult, formát öltött formái is: az „ortodox” konceptuális müvészetből élményszerűvé váló érzéki konceptualitás is. ${ }^{101}$ Andrási Gábor Erdély Optimista előadását idézi: „A művészet újra a vizuális és az érzéki hatásokat keresi.” ${ }^{102}$ És a pontosabb meghatározáshoz ugyancsak Erdély szavait hívja segítségül: „Az érzéki-konceptuális müben éppen a formák csillantják fel igazán a gondolat szépségét, s ezáltal a gondolat formái élményszerűvé, átélhetővé, megtapasztalhatóvá lesznek.”103 Majd Erdélyről úgy fogalmaz: „[...] [A]

100 Hegyi Lóránd: Új szenzibilitás. Magvető, Gyorsuló idő sorozat, Budapest, 1983.

101 Andrási Gábor: A gondolat formái. In: Nappali ház. 1993/2. sz. 70-77. o. Újraközölve: A gondolat formái. »Érzéki konceptualitás« a kortárs magyar képzőmủvészetben. In: A modern poszt-jai. Esszék, tanulmányok, dokumentumok a 80-as évek magyar képzömüvészetéröl. Szerk. Keserü Katalin. ELTE, Bölcsészettudományi Kar, Budapest, 1994. 75-87. o.; Henri Focillon: A formák élete. A nyugati müvészet. Ford. Vajda András. Gondolat, Budapest, 1982.

${ }^{102}$ Erdély Miklós: Optimista előadás. In: MI. 147. o.

103 Andrási Gábor: A gondolat formái. »Érzéki konceptualitás « a kortárs magyar képzőművészetben. In: A modern poszt-jai. Esszék, tanulmányok, dokumentumok 
fogalmiság, a konceptualitás visszavonhatatlanul - és tegyük hozzá: szándékainak megfelelően - eleven élettel telítődik mủvészetében." "104 És közben láthatjuk Erdély Miklóst a ’80-as években, amint a szellemi purizmus helyett újabb, nyughatatlan mediális kísérletezésekbe lendül, láthatjuk, amint gondolatai egyre inkább megfoghatóvá, élményszerűvé, érzékivé válnak, ahogy azt is, hogy ennek során még az addig elutasított „egyszerü és báva” festészethez is megérkezik - persze a sürü, vibráló gondolati indíttatást nem elhagyva. De érdemes Sugár János szavaira is figyelnünk, aki arra a fontos ívre hívja fel a figyelmet, hogy Erdély a pályája végéhez közeledve nem visszatalál a festészethez - ahogy az új szenzibilitás, az új festészet legtöbb képviselője -, hanem eljut oda. ${ }^{105}$ Beke

a 80-as évek magyar képzömüvészetéröl. Szerk. Keserü Katalin. ELTE, Bölcsészettudományi Kar, Budapest, 1994. 76. o.

${ }^{104}$ Uo. 82. o. Hegyi Lóránd az új szenzibilitást noha kezdetben többek közt a koncepualizmus elvont anyagtalanságának ellenpontjaként határozta meg, a fogalom a '80-as évek során olyan változásokon ment keresztül, hogy közvetlenül Erdély pályája után már az Andrási-féle érzéki konceptualitáshoz hasonlatos, intellektuálisabb új meditatív festészetet is magába foglalta. [Lásd: Hegyi Lóránd: Előszó az Új szenzibilitás IV. kiállításhoz. Az új szenzibilitás és az új festészet kibontakozása (1980-1986) c. rész. In: Új szenzibilitás IV. Kiállítási katalógus, Pécsi Galéria, 1987. Újraközölve: Az új szenzibilitás és az új festészet kibontakozása (1980-1986). In: A modern poszt-jai. Esszék, tanulmányok, dokumentumok a 80-as évek magyar képzömüvészetéröl. Szerk. Keserü Katalin. ELTE, Bölcsészettudományi Kar, Budapest, 1994. 89-97. o.; Közelítések. Bizonyos művészet-elméleti fogalmakról. A beszélgetés résztvevői: Bacsó Béla, Andrási Gábor, Bárdosi József, Bohár András, Hegyi Lóránd, Keserü Katalin, Novotny Tihamér, Sebeő Talán, D. Udvary Ildikó és Forgács Éva. In: I.m. 309335. o.]

${ }^{105}$ Sugár János: Emigráció a festészetbe. Erdély megvalósult és meg nem valósult művei. In: Új Müvészet. 1999. március, X. évf. 3. sz. 8-10. o. Újraközölt változatok: Uő: Emigráció a festészetbe. Erdély megvalósult és meg nem valósult 
László pedig úgy fogalmaz: „Erdély festészetében valóban megjelenik egy új érzékenységre törekvés, de másként, mint a magyar teóriában vagy a gyakorlatban.”106

művei. In: Magyar Mühely. 1999. XXXVII. évf. 110-111. sz. 104-108. o.; Uö: Emigráció a festészetbe. In: KGYFI. 453-457. o.

${ }^{106}$ Kurdy Fehér János: Kamillába mártott vatta. (Beke László Erdély Miklósról). In: Tiszatáj. 1992. XLVI. évf. 5. sz. 95. o. Erdély Miklós és az INDIGO csoport már a legelső, 1978 novemberében megtartott vitájuk és bemutatójuk témájául a Szén és szénrajzot választották. A közös (szét)definiáló munkát, a képzőművészet hagyományos médiumainak és fogalmainak újragondolását pedig többek közt olyan kiállításokkal folytatták, mint a Festmény (1979. március) vagy az Akvarell (1980. november). A Festmény címủ kiállításuk metaforikus installációiról Beke László a következőket írja: „Míg az absztrakció utáni irányzatok többsége materializálni próbálja a festészetet, az Indigo példázata nyitva hagyja a kérdést.” [Beke László: Súly és Festmény. In: Indigo. [A csoport 1977-81 közötti kiállításainak katalógusa.] Szerk. Erdély Dániel, Nemesi Tivadar. Budapest, 1981. Részletei újraközölve: In: KGYFI. 218. o.] Sugár János pedig az egy évvel későbbi témaválasztásukra, az Akvarellre emlékszik úgy, hogy - nem mellékesen az új festészet terjedésének idején - egészen egyszerủen abból a kérdésből indultak ki, vajon mi lenne a mủvészeti életben a „legcikibb” megnyilvánulás. Amihez hozzátehetjük, hogy Erdély, szintúgy az Akvarell kiállítás kapcsán, még 1982-ben is úgy fogalmaz: „Szerintem az, hogy [valaki] éppen ecsettel fest, ma már semmivel sem indokolható. Pláne, hogy egy olyan nem éppen gusztusos anyaggal dolgozik, mint amilyen a festék. Ez a ténykedés nekem abszolúte nevetségesnek tűnik. Olyan, mint egy régi mánia, egy régi mesterség. [...] [A]z Indigo csoporttal festettünk is; kíváncsiságból. Tudni akartuk, vajon abban is megnyilvánul-e az a szellem, amit képviselünk. Ezért tavaly akvarell-kiállítást rendeztünk a Bercsényi klubban. [...] [K]ifejezetten akvarellel festettem, persze, másképpen nézett ki, mint egy hagyományos akvarell-kép; hiszen fejesvonalzóval dolgoztam, de néhol azért engedtem, hadd folyjon.” [Csapó György: Közelképek. Beszélgetések. Képzőművészeti Kiadó, Budapest, 1983. 59. o. Részletei újraközölve: In: KGYFI. 295-296. o.] A festészetről pedig mint „,egyszerü és báva dologról” két évvel később, 1984-ben beszél, mikorra azonban már kialakítja saját, jellegzetes viszonyát a festészettel, mikor a konfrontáció pedzegetésén túl már nagyon is fest. Fest, csak éppen másként, mint festészetének tágabb 
kontextusa, a Hegyi Lóránd által meghonosított új szenzibilitás-teóriához sorolt alkotók, jelesül az új festészet képviselői. Kiegészítések között egyensúlyozva valahogy úgy fogalmazhatunk, hogy megjelenik Erdélynél egyfajta új érzékenységre törekvés, ám ő egészen organikus módon, mintegy gondolatait és módszereit a papírral és a vászonnal való találkozásban is alkotássá formálva jut el oda. Eljut oda, de nem is a festészet expresszív indíttatású talajához: munkáiban vizsgálva, dokumentálva, megtisztítva, életre és párbeszédre keltve az idea és az érzékiség egymástól elválaszthatatlan, egymást kölcsönösen kibontó és alakító kapcsolatát. A Kossuth Klubban 1984-ben végrehajtott Demokratikus festmény címú akciója során egy tüllfátyol alól provokálta a reflektorral megvilágított közönséget és persze önmagát: az őt mindig is különösképpen foglalkoztató hiba és véletlen helyett a kollektív, demokratikus döntések elöre nem látható irányaira reagálva festette meg képét, minden mozdulatát ellen- és megszavaztatva a jelenlévőkkel. Felvezetésként az akció tétjéről a következőket mondta: „Nagyon meglep engem az, hogy az emberek itt a saját bőrüket, nemcsak a bőrüket, de értékes szerveiket vitték a vásárra az utóbbi évtizedben az akcióművészet alkalmával, ami egy irgalmatlanul erős dolog. És ehhez képest hogy tud ezzel újra versenyképes izgalmat kelteni az a képtelenül egyszerü és báva dolog, hogy valaki vászonra olajfestéket ken. Mert az utóbbi években ez történt. A müvészettörténeti hányódtatás, a változás iránti igény lehet-e annyira erős, hogy egy ennyire erős és direkt dolgot mint az akciómüvészet, el tud halványítani néhány vászon? Ez nagyon foglalkoztat. Ezzel a mai akcióval éppen ezt a kérdést akarom irritálni.” [Erdély Miklós: Demokratikus festmény. In: MI. 171-172. o.] Erdély, miután elkészült a festménnyel, miután vásárra vitte, ha nem is a börét, de az ötletét, úgy értékelte az akciót, hogy hiába várta, mégsem történ igazán váratlan dolog. Hiába ült szemben a meghívottakkal, nem történt semmi olyan, amit nem lehetett volna előre látni. Nem volt senki, aki egyenrangú partnerként érdemben ellentmondott volna neki, senki, aki szemben állva/ülve az ötlettel alapvetően megkérdőjelezte volna az egész történést. Esetleg Hegyi Lóránd volt az, aki mủvészettörténeti megfontolások felé terelte volna az akciót és annak lenyomatát, a festményt -, de valahogy neki sem volt elég hangja hozzá. És egyébként is, ő még csak nem is Erdéllyel szemben foglalt helyet, hanem mellette ült, biztonságban, a tüllfátyol alatt. [Sugár János visszaemlékezéséröl lásd: Hornyik Sándor - Szőke Annamária: Akvarell [1980. november]. In: KGYFI. 295. o. A Demokratikus festményhez lásd: Babarczy Eszter: Határátlépő. Erdély Miklós. (értelmezési kísérlet). In: Új Müvészet. 1992. április, III. éfv. 4. 
sz. 6. o.; Forgács Éva: A neoavantgárd magánya. Erdély Miklós: Mủvészeti írások. (Válogatott müvészetelméleti tanulmányok). In: Új Müvészet. 1992. április, III. éfv. 4. sz. 83. o.; György Péter: Erdély Miklós - A szelíd botrány művésze. In: Holmi. 1992/8. sz. 1178. o.; Forgács Éva: Egy mítosz természetrajza. Erdély Miklós és a neoavantgárd magánya. In: 2000. MCMXCIII. október, 5. évf. 10. sz. 39. o.] Ahogy pedig Erdély, szintúgy 1984-ben, a Similis simili gaudet címü „alkalmi installációja” kapcsán az általa ekkor már nagyon is müvelt festészetről fogalmaz: „Jelenleg legszívesebben festek. Eddigi munkáimat a festői geometria fogalmával jellemezném leginkább. [...] Most valahogy közelítettem egy olyan látvány lehetőségéhez az utóbbi időben, amikor maga a geometria válik festői entitássá. De olyan puhán kezelni a geometriát, mint ahogy az életben az egzakt igazság fölmerül.” [A beszélgetés egy német tévéfilm számára készült: Ungarische Kunst heute. Rendezte: Dr. Michael Kluth. Közreműködött: Beke László és Hegyi Lóránd. WDF - WDR, 1984.] A festőivé váló matematikai jelekhez, geometriai ábrákhoz és a textúrába átforduló gondolatokhoz, a mindig éppen alakuló foltok, vonalak, ecsetvonások éteri tisztaságához két egymással érintkező alapmagatartást idézhetünk még Erdélytől. Festményein a semmibe átnyúló gondolatiság és a tiszta szépség között balanszírozva, kéz a kézben, egymáshoz simulva jár a „gondolat szépsége” és a „szépség gondolatisága”. [A kifejezéseket Erdély az Egyenrangú interjúban használja. A beszédszituációban Beke Lászlóra vonatkoztatja, hogy ebben az időszakban - az interjú 1978-ban készült - a müvészettörténész a szépség gondolatiságának vizsgálata helyett a gondolatok szépségének követésére van rákényszerítve.] Erdély Miklós életművét utólag szemlélve vélhetjük úgy - amint ezt többen meg is teszik -, hogy törekvéseinek íve összességében a „gondolat szépségétől” a „szépség gondolatisága” felé tart, s ezzel két, egymástól elkülönülő periódusra oszthatjuk pályáját. Azonban talán helyesebb, ha úgy látjuk, hogy pályavégi munkáiban a két megközelítés összeér, a két szemlélet egymásból merítkezik. [Lásd: Erdély Miklós - Beke László: Egyenrangú interjú. 1978. április 16. In: Hasbeszélő a gondolában. A Tartóshullám antológiája. (Jóvilág 3.). (Cápa 4.). Szerk. Beke László, Csanády Dániel, Szőke Annamária. Bölcsész Index, Budapest, 1987. 181-192. o.; Sinkovits Péter: Képzuhatag. A magyar festészet új hullámai az Ernst Múzeumban. In: Müvészet. 1984/12. sz. 49. o.; Szőke Annamária: Erdély Miklós festészetéről. In: Erdély Miklós. Kiállítási katalógus, Óbuda Galéria, Zichy Kastély, 1986. április 11. - május 5. 35-38. o.; Beke László: Erdély Miklós: Kollapszus Orv. In: Életünk. 1986. augusztus, 
Sorolhatjuk tehát a terminusokat: concept art, conceptual art, ötletmüvészet, gondolati müvészet, fogalommüvészet, fogalmi művészet, posztkonceptuális müvészet, új szenzibilitás, érzéki konceptualitás etc. Mindeközben pedig elgondolkodhatunk azon, hogy végül is a kategorizálással, a szűkebbre méretezett vagy éppen tágabb fakkokkal közelebb kerülünk-e Erdély folyamatos irányváltásaihoz. Imbolyoghatunk biztos fogást keresve a terminusok között, hogy minél stabilabban állva próbáljuk meghatározni Erdély törekvéseit - ám bármibe is kapaszkodnánk, időről időre biztosan körbeleng bennünket a gyanú, hogy valami olyat szeretnénk élesen fixálni, aminek az alaptermészete az, hogy kimerevíthetetlen, hogy besorolhatatlan. Erdély fluidumszerü életmüve tökéletes példája annak, ahogy a Marly tézisek koncepciója zárójelezi a műalkotás és a művészet stílustörekvések, irányzatok, tipizálható magatartás és szemléletmódok mentén történő értelmezhetőségét. Ahogy a tézisek a müvészettörténeti rekonstrukciók kategóriáit szétfeszítve a művészet minden külsődleges értelmezési kényszertől mentes autonómiájára irányítják a tekintetet. ${ }^{107}$

XXIII. évf. 8. sz. 749-750. o.; Szőke Annamária: Koncept, akció, életmód. Beszélgetés Legéndy Péterrel. In: Belvedere. 1991. III. évf. 1. sz. 43-49. o.; Mezei Ottó: „Gyürkőzz, János, rohanj, János”. A hatvanas évek új törekvései a Magyar Nemzeti Galériában. In: Kortárs. 1991/12. sz. 73. o. Újraközölve: In: Uő: Magyar, európai, modern. Válogatott írások. Vál. és szerk. Andrási Gábor, Pataki Gábor. Argumentum Kiadó, MTA Bölcsészettudományi Kutatóintézet, Művészettörténeti Intézet, 2013. 289. o.; Kurdy Fehér János: Kamillába mártott vatta. (Beke László Erdély Miklósról). In: Tiszatáj. 1992. XLVI. évf. 5. sz. 9293. o.]

107 A gondolatmenethez lásd még Bohár András Marly tézisekből kibomló tanulmányát a művészettörténet-tudomány szükségszerü önmegújításáról: Bohár András: A művészetfogalom változásának dimenziói. In: A modern poszt-jai. 
A harmadik kiegészítés a tézisek után három évvel, 1983-ból Erdély Miklós saját besorolás-értelmezése és javaslata: „Szerintem mindenki kényelmetlenül érzi magát ebben a besorolásban. Egyszerre fölébred, és akkor azt mondja: Mi az, ja, én koncept művész vagyok... és akkor hiába dörgöli a papírt, lucskolja a vásznat...”108 És ugyancsak idetartozik az 1985-ös kalocsai Magyar Mühely-találkozón elhangzott előadásának vázlata is: „Irányzat képviselőiként tárgyalt müvészek. Kartotékszisztéma. [...] Az elméletben lenne jó egy új irányzat; az egyedi elemzés, a nem irányzat szerint való értékelés. Valahogy úgy, [hogy] ami irányzat jellegü, az rossz. Minden mü annyira gyenge, amennyire hagyja magát irányzathoz tartozónak tekinteni.”109 Valamint magának a kalocsai előadásnak a videofelvétel alapján közreadott szövege: „Tehát, hogy ha valami egy irányzat, az már nem az én ügyem. Abban a pillanatban, mikor irányzatba sorolom, ez annyit jelent... hogy annak vége, az egy közhely.” 110

Esszék, tanulmányok, dokumentumok a 80-as évek magyar képzömüvészetéröl. Szerk. Keserü Katalin. ELTE, Bölcsészettudományi Kar, Budapest, 1994. 29-40. 0.

108 Peternák Miklós: Beszélgetés Erdély Miklóssal 1983 tavaszán. In: Árgus. 1991. szeptember-október, II. évf. 5. sz. 75. o.

${ }^{109}$ Erdély Miklós: [A kalocsai előadás vázlata]. In: MI. 183. o. Ugyancsak az előadás vázlatából: „Manapság egy művész attól művész, hogy folytonosan megváltozik. Ha képes arra, hogy ne hagyja magát utolérni a divatok által, úgy megőrizheti űzött szabadságát." Az előadás vázlatát tartalmazó füzetbe, az idézetet megelőző egyik lapra Erdély egy táblázatot is készített a XX. századi irányzatok felsorolásával. [Uo. 184. o. Lásd még: Peternák Miklós: Szerkesztői jegyzetek. In: MI. 213. o.]

${ }^{110}$ Erdély Miklós: [A kalocsai előadás]. Videofelvétel alapján. In: MI. 197. o. 


\title{
A semmi felől
}

\author{
„Ha lassan megérted, miképpen \\ nincs, ami van, úgy nevében érted \\ meg, és neve erősebb valósággá \\ válik. Távolodva lásd egyre \\ élesebben!”111
}

A művészet fogalmának vallatóra fogását itt abba is hagyhatnánk, hiszen jelentése üres, egyszerủen nem jelent semmit. Az eddigiek alapján annyit mondhatunk biztosan: a művészet, a müalkotás - és egyben a szabadság - úgy határozható meg mint korlátlan, nem korrelatív, tiszta eldöntetlenség. Nem tudunk többet mondani róla, mert közelebbröl csakis a semmit tudjuk elmondani róla.

Ahhoz azonban, hogy körbejárjuk, a felkínált üres helynek milyen vetületei vannak még Erdély életművében, néhány további gondolatát, a tézisektől eltérő, ám azokkal mégis egy irányba tartó megközelítését fogom egybegyüjteni. Ennek során pedig kiderül majd, hogy a „semmi” nagyon is „valami”. Erdély teóriája szerint a müalkotással való találkozás a megcsontosodott gondolati sémák szétfeszítésén és a fogalmiság feloldásán át tarthat az üresség felé. Az üresség azonban - és ebben a fejezetben ezt szeretném bemutatni - csak ebből az irányból jelentésnélküli, meghatározhatatlan. A semmitől távolodva, ha visszapillantunk rá, láthatjuk úgy is, hogy ez volt minden jelentés legstabilabb kiindulópontja. A következők így meglehet, első látszatra a Marly téziseknek némileg ellentmondanak, ám összességében nem ellenpontozni, hanem kibontani szeretnék a „semmi dinamikáját”.

${ }^{111}$ Erdély Miklós: Mondolat. In: MK. 6. o. 
1980-ban, a Bercsényi Kollégiumban mutatta be Erdély Miklós A kalcedoni zsinat emlékére címü environmentjét. Kátránypapírból a terem padlójának egészét lefedő keresztet formált, melynek széleire üveglapokat fektetett. A kereszt közepére egy kötegnyi maceszlapot helyezett, majd forró ólommal végigöntötte a kereszt szárait, a metszéspontot beleégetve a macesztömb mélyebb lapjaiba is. A kereszt végében egy lefordított tepsire állt, majd égő cipőfüzőkkel megtartotta beszédét, mely egyszerre volt a mü része és a mű széleskörü, legteljesebb interpretációja. Előadásában anyagok, jelentéstömegek és tradíciók keresztezték egymást, miközben a macesz és az olvasztott ólom találkozásából felszálló friss kenyérillat lengte be a teret. Itt hívta fel a figyelmet a terem falán fejmagasságban körbefutó telexpapír fontosságára, átfogó, a munkát nem csupán fizikálisan keretező jelentőségére. A kék telexcsík egy-egy kátránypapírsávból indult, s oda érkezett meg, áthaladva a bejáraton is, fejhajtásra késztve a belépőket. A telexpapíron végtelenbe tünő, halványodó tizedestört futott végig: „Az univerzum 99.99999999...\%-a fölösleges.” Erdély értelmezésében: „Elhalványodó végtelen tizedesek: a tudat ellenmozgása, s mint ilyen, realista emberábrázolás. [...] Szerepel itt még egy fölirat, hogy »az univerzum 99,99\%-a fölösleges.« Ennek kilencesei fokozatosan halványodnak, és - amint már fölolvastam - itt egy más dimenzió ellenmozgást végez és ezáltal halványodik el. Tehát fölfoghatjuk úgy, hogy az, ami a világegyetemben nem fölösleges, az halványítja ezt a százalékot.”112 A látogatók a teremben körbesétálva a semmibe vesző számsor mentén haladhattak, lépésenként közeledve a leghalványabb 9eshez, mely talán már a „másik dimenzió” határán van. Közben pedig

\footnotetext{
${ }^{112}$ Erdély Miklós: Előadás a kiállításról. (Magnófelvétel után). In: MI. 148-149. 0 .
} 
eltűnődhettek azon, hogy mi is az, ami mindent elhalványítva ellenmozgást végez. Azon, hogy mi az, ami a világegyetemben nem fölösleges. Azon, hogy mi lehet a halványodó számsor végén, ahonnan visszanézve már minden csupán fölösleges. ${ }^{113}$

113 1980-ban az environment két változatban is elkészült: az egyik a Bercsényi Kollégiumban, a másik a genti Museum van Hegendaagse Kunstban rendezett 6 Hongaarse Kunstenaars címü tárlaton volt látható. Gentbe Erdély nem tudott kiutazni, mivel nem kapott útlevelet. Ide a telexpapírt még maga készítette el és küldte ki, az environment többi elemét pedig az instrukciói alapján a kiállítást rendező Jan Hoet és az ott szintén kiállító Károlyi Zsigmond, Hajas Tibor, valamint Halász András állította össze. [Ezúton is köszönöm Tillmann J. A. jelen szövegen jóval túlmutató segítségét. A munkáról lásd még: Tillmann J. A.: „Nem hiszem, hogy még egy ilyen ember van a világon.” Erdély Miklós és A kalcedoni zsinat emlékére. In: Magyar Mühely. 1999. XXXVII. évf. 110-111. sz. 37-43. o. A tanulmámy némileg rövidebb és hosszabb változatai: Uő: „Nem hiszem, hogy még egy ilyen ember van a világon.” Erdély Miklós és A kalcedoni zsinat emlékére. In: Pannonhalmi Szemle. 1999. VII. évf. 1. sz. 100-105. o.; Uő: Erdély Miklós és A kalcedoni zsinat. In: Uő: Meröleges elmozdulások. Utak a modern müvészetben. Új Palatinus-Könyvesház Kft., Budapest, 2004. 79-90. o. Interneten: http://www.c3.hu/ tillmann/irasok/muveszet/erdely.html; 2012. 11. 12.; Hajdu István: Kalcedon - a kétely, a kétség, a kettősség, a hármasság és a négyesség. In: Magyar Mühely. 1999. XXXVII. évf. 110-111. sz. 156-161. o.; Beke László: Erdély Miklós munkássága. Krono-logikai vázlat képekkel 1985-ig. In: Erdély Miklós. Kiállítási katalógus, Óbuda Galéria, Zichy Kastély, 1986. április 11. - május 5. 22. o.; Szőke Annamária: Erdély Miklós műveinek restaurálása és rekonstrukciója. In: Magyar Mühely. 1999. XXXVII. évf. 110 111. sz. 129-130. o.; Hornyik Sándor: Naiv realizmus és „természettudományos koncept". A modern természettudomány helye Erdély Miklós müvészetében. In: Magyar Mühely. 2004. XLIII. évf. 131. sz. 42-44. o.] Az 1981-ben elhangzott Apokrif elöadásban is visszatér Erdély néhány mondat erejéig $A$ kalcedoni zsinat emlékére készített environmenthez: „[...] [A] bibliát gyógyvizekkel megjelenítem. Szimbolizálom. Tehát régen az esők, amik felülről jöttek, és a kinyilatkoztatásként is értelmezhetőek, beszivárogtak a föld alá és forrásvízként alulról törnek fel. [...] [Cs]ak tiszta gyógyforrásból merítek. Különösen tetszett 
Ahogy már utaltam rá, Erdély egy évvel korábban, 1979-ben az INDIGO csoporttal beszélgetve úgy fogalmaz, hogy a müalkotás utat készít elő a kilépésre: „Furcsa módon a mosoly mindig egy kilépés, nem tudom,

nekem az, hogy akik a Happening címszó alatt nagy, durva eseményeket vártak, azok csak néhány gyógyvizes üveget és kis viráglocsolást tapasztaltak. Én enyhe kajánsággal figyeltem ezeket a csalódottságokat. Körülbelül itt tartottam a gondolatmenetben és idáig is írtam le, mikor tegnap este hazamentem, hogy befejezzem ezt a kis írást, a mai előadást. Mikor bementem a szobámba, akkor a falamon volt a Bercsényi utcai kiállításon szereplő művem. Egy nagy kátránypapírkeresztet csináltam és a közepére maceszt, zsidó kenyeret raktam, aztán forró ólommal leöntöttem kereszt alakban. Ennek a közepét kivágtam, és mivel máshol nem tárolható és különben is elég lényeges jel, a falamra szögeztem ki az ágyam mellé. Elég súlyos rajta az ólom meg a macesz. Tegnap bemegyek, és azt tapasztalom, hogy az ágyamon fekszik az egész, leszakadt a falról. Ettől azonnal szorongást kaptam, különösen, mert magam sem voltam biztos abban, hogy ilyen kritikusan vagy ennyire közvetlenül joga van-e egy embernek egyáltalán foglalkozni a Bibliával. Szinte úgy tünt, hogy na, megérkezett az égi jel, mert leszakadt a kép. [...] Ettől baromira megijedtem. Nem lesz előadás ma mondtam -, a diákat elégetem és a negatívját is nyomtalanul ki kell irtani. [...] Aztán leültem, és elkezdtem gondolkodni azon, hogy vajon hol követtem el hibát, mi a bűnöm. [...] Azt kapizsgáltam, amikor elhatároztam, hogy milyen akciót csinálok, hogy a gyógyvizet azonosítottam a Bibliával. Ez már maga egy mágikus eljárás. [...] [A]mit a gyógyvízzel teszek, azt tulajdonképpen a Bibliával teszem. Most nézzük meg, hogy mit müveltem a Bibliával. Mindenekelött öntöztem ezt a kis virágot. Ezt jól tettem, ebből semmi bajom nem származik. Ittam, ezt is nagyon jól tettem. A következő, ami már nagyon gyanús, az, hogy kicsorgattam. [...] [T]ulajdonképpen a hibák hiábavalóságát csorgatom ki, és így a tagadás tagadásával mondjuk ellene dolgoztam a hiábavalóságnak. Ez volt a reményem.” [Erdély Miklós: Apokrif előadás. In: MI. 161-163. o. Elhangzott az Új irányzatok napjaink müvészetében címü, Körner Éva által szervezett TIT müvészettörténeti előadássorozat keretében, 1981. december 2-án, az FMK-ban. (A fluxus és a happening téma kapcsán Erdély saját, 1981. november 25-én, a Műegyetemen megtartott akciójáról.)] 
miből... Ezen gondolkozom, hogy miből lépek ki. Nem tudom.”114 S Erdély mondatait, miszerint nem tudja, miből történik a kilépés, érthetjük úgy is, hogy csak a kilépés hová-ja igazán meghatározható: „[...] [M]ilyen őrült szüksége van az embernek az állandó megújulásra, a kilépésre. És az örök érvényes dolog irányába tud kilépni.”115 A jelentéskioltás az üresség felé kilépés lehetősége. Viszont oly paradox módon, hogy ez az üresség a maga jelentésnélküliségében mégis az egyetlen meghatározható állandó. A semmi körvonalazása így pedig nem csupán a megtisztuló gondolkodás folyamatának a jellemzése - Erdély szavaival „realista emberábrázolás” -, hanem a semminek mint abszolútumnak az objektivitásra törekvő leírása is.

A műalkotás ideális esetben a „semmi” felé vezet. Ahogy Deréky Pál írja: „Nem született általános érvényű megállapodás arról - legalábbis én nem tudok róla -, hogy mi legyen a jelentéskioltás után, mi legyen a »hely« sorsa. Alighanem szerették volna függőben tartani, amíg csak lehet [...].”116 A függőben tartáshoz finoman hozzáilleszthetjük Erdély végtelenítő megjegyzését: „Kész van, ami készül.”117 Ám a „hely sorsát” fürkészve Erdély gondolatainak mélyebb rétegei felé tarthatunk. Semmibe átnyúló törekvéseit láthatjuk úgy, hogy nem csupán az értelmezési raszterek, a látens világképek fokozatos lebontásáról szólnak, de az üres hely, a semmi érintésén át a folyamatos megújulás lehetőségéről is. Semmiképp sem egy új konstrukció stabilizálásáról, avagy az üres hely

114 Téma: A költészet. Az Indigo csoport beszélgetése az Erdély Miklós Költői avantgarde címü pécsi előadásához kapcsolódó kiállításról 1979. november 7-én. In: KGYFI. 256. o.

${ }^{115}$ Uo. 275. o.

${ }^{116}$ Deréky Pál: A magyar neoavantgárd irodalom. In: Né/ma? Tanulmányok a magyar neoavantgárd köréből. Szerk. Deréky Pál és Müllner András. Ráció Kiadó, Budapest, 2004. 36. o.

${ }^{117}$ Erdély Miklós: Idő-mőbiusz. In: MK. 95. o. 
feltöltéséről, hanem egy végtelenbe gyürüző, mindig megújulni képes körforgásnak a lehetőségéről. S azt hiszem, igazán ehhez, halványodva a semmi felé tartó, a semmit érintő és az onnan távolodó, majd újra és újra visszakanyarodó körforgáshoz, a megszokások leülepedésének, a megismerés önmagába záródásának a mindig továbblendítéséhez hozzáolvasva lesz teljesebb Erdély mondata: „Kész van, ami készül.”118

A semmi abszolútumszerű meghatározását Erdély újabb és újabb adatokkal pontosítja. Az általa is több ízben (meg)idézett Heidegger a kiürítés és a megtöltés folyamatát helyezi egymásra, s ezzel az üresség hiányként való leírását oldja fel. „A pohár kiürítése azt jelenti: azt mint magába fogadót szabaddá-váltjába gyüjteni. [...] Az üresség nem semmi. Nem is hiány." 119 Erdélynél pedig:

A semmi csak úgy tud igazán semmi lenni, ha magát folyamatosan újratermeli; akárcsak a valami. [...] Hej, ezért van valami és ezért nincs inkább semmi, degger. ${ }^{120}$

\footnotetext{
${ }^{118}$ Uo.

${ }^{119}$ Martin Heidegger: A művészet és a tér. In: Martin Heidegger:
} költöien lakozik az ember...” - Válogatott írások. Vál., szerk. Pongrácz Tibor. Ford. Bacsó Béla, Hévizi Ottó, Kocziszky Éva, Pongrácz Tibor, Szijj Ferenc, Vajda Mihály. TTwins Kiadó, Pompeji, Budapest, Szeged, 1994. 217. o.

${ }^{120}$ Erdély Miklós: Aranyfasisztáim. In: MK. 21. o. Ha a jelentéskioltás önmagán túlmutató szimbolikáját végigkövetjük, kitünik, hogy a kioltást Erdély többször társítja a fasizmus brutális pusztításával. S habár a jelentéskioltást alapvetően nem ez a képzettársítás határozza meg, több munkáját láthatjuk ebben a fényben, ahogy több, kifejezetten a müvészi jelentéskioltást taglaló gondolatmenetében is, ha csak egy-egy, jelzés értékű szó erejéig, de megjelennek a „hullahegyek”. Csapó György 1982-ben készített interjút Erdély Miklóssal, akit az egy évvel korábbi Marly tézisekről kérdezett. Erdély magyarázata a kioltásra: „Mondjuk, ha ezt a cigarettáscsomagot, ami a kezemben van, kinevezem müalkotásnak, akkor ez azért nem lesz igazi mint müalkotás, mert bár üres, de nincsenek benne kioltott jelentések. Nagyon fontos az, hogy a jelentéseket magára vegye a műalkotás; 
Az értelmezés kibővülése, a fokozódó jelentésexpanzió egy idő után a visszájába fordul, a jelentéskioltás a semmit „tölti meg”. Az Új adatok a semmiről szerint: „Koncentráció által minden képes áthorpadni saját hiányába.”"121 Avagy: „Bármennyire is ellene szól a közvetlen tapasztalat, lehetetlen csökkenés által kimúlni - csak fokozódás által lehet megszűnni. (a mennyiség saját hiányába csap át) [...].”122 Ám Erdély szerint a semmi felé tartó folyamat meg is fordítható. Ahogy írja: „Minden létező a semmi

felerősítse és szinte egymással oltassa ki. A műalkotást tehát egy kioltott jelentésekkel telített tartálynak tekintem, amely jelentés-hullákkal van tele.” [Csapó György: Közelképek. Beszélgetések. Képzőmüvészeti Kiadó, Budapest, 1983. 60-61. o.] Ahogy fentebb, az Aranyfasisztáimból idézett sorok sem éppen a művészi jelentéskioltást taglalják, sőt. Ezt a verset 1945 negyvenedik évfordulóján írta Erdély. Egy másik részlete: „Most, hogy negyven év után első felháborodásomból | felocsúdtam, | most, hogy a természetes és mesterséges hullahegyek | mérete kiegyenlítődni látszik, | most, hogy a »fasiszta itt minden« gyanúja kezd | belém fészkelődni, | hogy az anyaméhbe egyenként bevagin bevaginozott, | bewagonírozott lelkeket számlálok [...]" [Erdély Miklós: Aranyfasisztáim. In: MK. 20. o.] Erdély többek közt ezt a versét olvasta fel 1985. február 27-én a Magyar Írók Szövetsége székházában tartott felolvasóestjén: előadásában az egymás mellé válogatott versek és szövegek montázsszerüen kötötték össze a kioltást és a semmit a fasizmus pusztításával, miközben egyszersmind el is különítették attól. Az esten egy akció is zajlott: Györe Balázs egy időre átvette Erdélytől a felolvasást, míg ő leemelte a terem ablakait, majd néhány indigós havat hordott fel, amit a teremböl visszadobtak az üres ablakokon át. [Az elhangzott verseket, szövegeket, az estről készült hangfelvétellel és fotókkal együtt lásd/hallgasd az Artpool Müvészetkutató Központ honlapján: http://artpool.hu/Erdely/aranyfasisztaim.html; 2014. 02. 01. Lásd még Erdély ezidőtájt, feltehetően az Aranyfasisztáim című verse után született, azonos címü festményét.]

${ }^{121}$ Erdély Miklós: Új adatok a semmiről. In: MK. 98. o. ${ }^{122}$ Uo. 
hígított változata.”123 Másként fogalmazva a két irányról: „A fokozódó koncentráció végén a semmi áll.”124 Ugyanakkor: „[...] [A] fokozhatatlan semmi fokozódó valamivé csap át [...].”125 De milyen is a semmi, ami képes átcsapni valamivé?

A semmi végtelen és örök potencialitás. [A semmiröl]-ben véglegesnek, öröknek írja le; a Sejtések I.-ben pedig talán ugyanerre vonatkozik a gömb metaforája:

24. A kocka gömb az élekre torlódott görbülettel.

25. A forgás által végtelenített folytonosság egyensúlyi pályáját egészen kényszerül betölteni, mert nincs akadálya, hogy betöltse. Így gerjed a burok, burok által a rész. ${ }^{126}$

A semmit mindentől való függetlenségében jellemzi. Tovább finomítva, a semmi még csak nem is negatívumként megragadható, hanem inkább érintkezés nélküli véglegesség: „A semmi nem valamiben semmi, hanem a semmiben semmi. [...] A valami nem a semmiben valami, hanem a valamiben valami. [...] Valami és valaminek a hiánya keveredhet, de nem érintkezhet.” ${ }^{27} \mathrm{~S}$ akkor a semmiből hogyan lehet mégis valami? „A semmi hígulása nem úgy értendő, hogy a semmiben megjelenik valami, hanem a semmi válik valamivé (híg valamivé).”128

\footnotetext{
${ }^{123}$ Uo.

${ }^{124}$ Uo.

${ }^{125}$ Uo.

${ }^{126}$ Erdély Miklós: Sejtések I. In: KO. 91. o.

${ }^{127}$ Erdély Miklós: Új adatok a semmiről. In: MK. 98. o.

${ }^{128}$ Uo. Ahogy pedig a Miserere orv.-ban szerepel. „Ami a semmiben születik, az valami, ami zürzavarban születik, az semmi." [Erdély Miklós: Miserere orv. In: KO. 11. o.] Ide, a valami semmi felé vezető kioltásához és a semmi valamibe való átcsapásához kívánkozik Erdély két, összetartozó fotósorozata, melyek egyben két akciójának a dokumentációi: az 1969-ben készült Önvilágítás (A fény megeszi az
} 
embert) és az egy évvel későbbi Esti akció. Az Önvilágítás két fotója azt a pillanatot kapja el, amint Erdély egy vakuval közvetlen közelről saját arcába villant, kisütve az erős fényben eltorzuló vonásait. Az akció-fotók könyörtelenül szó szerint veszik az önvilágítás szimbolikus aktusát. Ennek a folyamatnak mintegy a megfordításaként értelmezhetjük az Esti akciót dokumentáló fotókat: Erdély létrán áll a kertben, hogy elérje az éjszakát bevilágító lámpát, s a lámpa buráját fehér festékkel akkurátusan addig keni, mígnem sötét lesz. Azaz, ahogy Beke László fogalmaz, itt „az ember eszi meg a fényt.” Az Önvilágításhoz lásd még Erdély sorait Birkás Ákos 1981-es bemutatójához készült írásából: „Tönkrefotózni xeroxszal a látszatot a lényeg védelmében. Nincs önmegtagadóbb vállalkozás egy festő részéről, aki mindig is a látszatból olvasta ki, bontotta ki a lényeget. A festő, mikor masinájával a látványra vaktában tüzel, Oedipusz király módjára égeti ki saját szemét. Birkás vakuval szeret fényképezni. Jómagam 15 évvel ezelött a szemembe vakuztam. Rosszul látom Birkás müveit." [Erdély Miklós: Birkás Ákos fotókiállításáról. In: MI. 112. o.]

De szintúgy idekívánkozik az első, talán legkevésbé gondolati, inkább tisztán emocionális igényű environmentje, az 1977-ben készített Bújtatott zöld is. Erdély erős filmgyári reflektorral világította meg a bejáratot, teljesen elvakítva az álomszerü, sötét, zöld terembe belépőket. A látogatók szinte megvakulva, az éleslátás sebtében rendszerező rutinját kénytelenül kívül hagyva csak fokonként fedezhették fel a bizonytalan teret: próbálhattak zöld ceruzával hunyorogva írni egy paravánnal elkerített, zöld lámpával megvilágított asztalon, megérkezhettek a terem leghátuljában felállított erdei etetőszerü építményhez, s alá bebújva, majd feltekintve láthatták a plafonon fehérrel megvilágított, „bújtatott”, keskeny, elevenzöld textilcsíkot, de tapogatózhattak a mintegy ötven darab vékony falécen álló felhő alatt, és körbejárhatták - avagy ráléphettek - a termet beborító szénában tisztán hagyott fehér, „transzcendens” helyre is. Az üres folt tisztántartását egy odatámasztott cirokseprü biztosította, melynek meghosszított, felfelé tartó nyele az álomszerüen földön álló felhő sudár lábaira rímelt, mintegy összekötve a talajon kitapinthatót az égivel. A látomásszerü tér egyáltalán nem akart könnyen kezelhető asszociációkkal dolgozni, s többek közt éppen ezért, az indoklás szerint értelmezhetetlensége és zavart keltő müfaji besorolhatatlansága okán csupán öt napig engedélyezte a zsüri a nyitva tartását. (A zöld homályban politikai utalásokat sejtő zsüri egyik neurotikus kérdése az volt, hogy árulja már el Erdély, mit akar ezzel a bújtatott zölddel - merthogy valamiben settenkedik, az biztos. Ugyanis volt, aki arra asszociált, hogy „kis nyilasok bújtatása a pártban”. 
Erdély válasza: a zöld a remény színe.) Az environment lebontása előtt Erdély kvázi a szakértő zsűrire is reagálva - egy szamarat vezetett be a terembe, melyre úgy emlékszik: „A csacsi csak később jött, mert mikor bezárták a kiállítást, akkor hoztam egy csacsit, hogy legeljen... azt megvilágítottuk reflektorral. A csacsi viselkedése különben félelmetes volt: jellemek a csacsik. [...] Itt se lehetett irányítani, ennél a szénaevésnél az állatot, egyáltalán. Az az érdekes, hogy az emberek nagyon sokan nem vették észre vagy nem vették komolyan ezt a fehér foltot a Bújtatott zöldnél. Kb. 2 méter átmérőjű kör, azért volt ott a söprü, hogy ha valaki rámegy, és berugdossa a szénát, ki lehessen söpörni, hogy mindig tiszta legyen. A csacsit nem lehetett ráhúzni a fehér körre, nem volt hajlandó rálépni. Arról van egy képem, hogy tiszta erőből húzom, és abszolút nem hajlandó mozdulni. Az érezte ennek a kitüntetett voltát, szóval hogy az nem ugyanaz a közeg, az egy transzcendens közeg.” [Peternák Miklós: Beszélgetés Erdély Miklóssal 1983 tavaszán. In: Árgus. 1991. szeptember-október, II. évf. 5. sz. 83. o.] Utólag, 1980 körül, Bartholy Eszterrel beszélgetve már egészen határozott asszociációkkal fixálja Erdély a vékony lábakon álló felhőt és a megfoghatatlanul üres helyet: „A feltámasztott felhő azonos egy benne [Erdély Miklósban] valamikor az új müvészetről megfogalmazódott elvi elképzeléssel: a ballont, ami a müvészet irracionális, a dolgok felett lebegő voltát hivatott kifejezni, a legújabb tudományos világkép téglát téglára rakva lassan aláfalazta. A Gödel-tételből következik - és erre is utal ez az alátámasztott tárgy -, hogy minden állítás végtelen számú előfeltevésen nyugszik, és, mint ilyen, igazolhatatlan. Ezeket az előfeltevéseket, előitéleteket hivatott az ember föltárni. Erdélynek most utólag tetszene, ha ráírta volna erre a felhőre, hogy »Gödel«, mert ezek az elképzelések, ha nem is ilyen tudatosan, de éltek benne a Bújtatott zöld idején.” Majd később: „A Bújtatott zölddel a mủvész ismét kikezdi a vele szemben fennálló elvárásokat. [...] Mint mondja, akiben van a transzcendencia felé némi nyitottság, az nem fogadja el ezt a státuszt, ezt a többiek számára könnyen elfogadható viseletet. Nem lehet a végítéletkor megjelenni semmiféle jelmezben; egy, fölfelé mutató területet minden eshetőségre - akár léteznek az ember transzcendens vonatkozásai, akár nem - tisztán, mintegy meztelenül kell tartani, erről le kell söpörni a szereprárakódásokat. [...] Az új rafinéria egy müvön belül is és egy életen belül is a jelentés kioltására törekszik. [...] [A] jelentéskioltás végtelen folyamat.” [Bartholy Eszter: Erdély Miklós: Bújtatott zöld. In: Magyar Mühely. 1983. július, XXI. évf. 67. sz. 65-66. o. A Bújtatott zöldhöz lásd még: Beke László: Erdély Miklós munkássága. Krono-logikai vázlat képekkel 1985-ig. In: 
A semmi leírásában a német idealizmus abszolútuma cseng vissza. Schelling adja $A$ müvészet filozófiájában az abszolútum olyan meghatározását, melyet a semmire vonatkoztatva akár egy az egyben átmásolhatnánk Erdély gondolatai közé: „Magában az abszolútumban nem fordulhat elő semmi, ami előtte vagy utána van, tehát olyan más

Erdély Miklós. Kiállítási katalógus, Óbuda Galéria, Zichy Kastély, 1986. április 11. - május 5. 17. o.; Szőke Annamária: Erdély Miklós müveinek restaurálása és rekonstrukciója. In: Magyar Mühely. 1999. XXXVII. évf. 110-111. sz. 128-129. o.; http://www.artpool.hu/Erdely/mutargy/Bujtatottzold.html; 2013. 06. 01.; Szipőcs Krisztina: Történetek Erdély Miklósról. In: Balkon. 1998/11. sz. 4-8. o. A zsűri döntésének dokumentumát lásd: http://www.artpool.hu/Erdely/mutargy/Bujtatottzold dok.html; 2013. 06. 01. Az Önvilágításhoz és az Esti akcióhoz lásd: Beke László: Erdély Miklós munkássága. Krono-logikai vázlat képekkel 1985-ig. In: Erdély Miklós. Kiállítási katalógus, Óbuda Galéria, Zichy Kastély, 1986. április 11. - május 5. 9. o.; Beke László: Fotó/müvészet. In: Expozició. Fotó/müvészet. Kiállítási katalógus, Hatvany Lajos Múzeum, Hatvan, 1976. október 24. - 1977. január 31. A Hatvany Lajos Múzeum Füzetei No 2., MÉM STAGEK sokszorosító 367/76. o.n.; Beke László: Fotó-látás, fotóhasználat az új magyar müvészetben. In: Uő: MÉDIUM/ELMÉLET. Tanulmányok 1972-1992. Balassi Kiadó - BAE Tartóshullám - Intermédia, Budapest, 1997. 24. o.; Beke László: Elektromosság és mủvészet Magyarországon. In: Uő: MÉDIUM/ELMÉLET. Tanulmányok 1972-1992. Balassi Kiadó - BAE Tartóshullám - Intermédia, Budapest, 1997. 236. o.; Perneczky Géza: Erdély Miklós, és műve, a dekonstruktív tautológia. In: Erdély Miklós 1928-1986/. Kiállítási katalógus, Csók István Képtár, István Király Múzeum, Székesfehérvár, 1991. október 26. - december 31. 14. o.; Kollár József: Agyírás, elmeolvasás. Erdély Miklós retrospektív kiállítása. In: Új Müvészet. 1999. március, X. évf. 3. sz. 6. o.; Szombathy Bálint: Erdély Miklós Fényismeretkölteménye. In: Magyar Mühely. 1999. XXXVII. évf. 110-111. sz. 29-31. o.; Szegő György: Fotó/szeánsz: Erdély Miklós. In: Magyar Mühely. 1999. XXXVII. évf. 110-111. sz. 139-140. o., 143-144. o.; Szilágyi Sándor: Neoavantgárd tendenciák a magyar fotómüvészetben 1965-1984. Fotókultúra - Új Mandátum Könyvkiadó, Budapest, 2007. 332-333. o.; Madácsy István: Transzparencia. A fény müve és a mü fénye. DLA értekezés, Magyar Képzőmüvészeti Egyetem, Doktori Iskola, Budapest, 2009. 29. o.] 
meghatározás, amely megelőzi vagy követi. Mert ha előfordulhatna, akkor az abszolútumban valamilyen affekciót vagy szenvedést kellene tételeznünk, azt, hogy valamiképpen meg van határozva. Ám az abszolútum teljesen affekciómentes, nincs benne semmiféle szembeállítottság.”129 A Sejtések II. tömör téziseiben Erdély a következőképpen összegez:

1. Semmi nem történik.

2. A semmi történik.

[...]

24. Semmi nincs.

25. Semmivel történik minden. ${ }^{130}$

Másként fogalmazva: „Most aztán tényleg minden érzékletességet félretéve: minden semmik nem valaminek a hiányaként nincsenek, hanem mindentől függetlenül, nem negatívumként, hanem érintkezés nélkül, semmilyen lehetőséggel nem érintkezve és véglegesen. Az egyetemes semmi örökre és véglegesen sérül bármitől, ami nem az."131 A nincs és a van végső tautológiája a Nagy számokban: „NINCS VAN, DE NINCS VAN."132

A NINCS és a VAN között pedig ott a határ - melynek fogalmát eddig többféleképpen használtam. Próbáltam nem fixálni, inkább a különböző gondolatok kapcsán aktualizálni, hogy miféle határ sértéséről van, lehet szó Erdélynél. Ugyanis - ahogy itt talán már kitünik - a jelentéskioltás a megismerés legtágabban érthető, bármiféle behatárolását számolja fel. Az üresség, a semmi felé törekvő határsértés nem csupán a bináris logikai és nyelvi-logikai tér korlátainak a megrepesztése, hanem így

${ }^{129}$ F. W. J. Schelling: A müvészet filozófiája. (A kéziratos hagyatékból). Ford. Révai Gábor. Akadémiai Kiadó, Budapest, 1991. 84. o.

${ }^{130}$ Erdély Miklós: Sejtések II. In: KO. 92-93. o.

${ }^{131}$ Erdély Miklós: Új adatok a semmiről. In: $M K .99$. o.

${ }^{132}$ Erdély Miklós: Nagy számok. In: KO. 104. o. 
látszik végre megoldódni a kanti világkép problémája is. A megismerés kantiánus korlátai feszülnek a Dirac a mozipénztár elött címü akcióban:

1. Hogy van tehát?

2. Idő és tér tehát?

3. Hagyjuk ezt!

4. Gondolkodásunk formái tehát.

[...]

3. Tér és idő a bele nem illeszkedés fájdalmának formája tehát.

[...]

2. A gondolkodás belemagyarázza magát

3. oda ahol nincs tehát.

[...]

2. A megértés megszabadulás tehát. ${ }^{133}$

${ }^{133}$ Erdély Miklós: Dirac a mozipénztár előtt. (Négy férfihangra). In: KO. 57-58. o. 1968. november 29-én az IPARTERV Vállalat székházában Erdély Miklós, Urbán Miklós, Cseh Tamás és Szentjóby Tamás három ismeretelméleti és természettudományos akciót mutatott be Három kvarkot Marke királynak címen, melyek közül a második a Dirac a mozipénztár elött címet kapta. Az aktorok libasorban araszolva haladtak a kijárat irányába, miközben minden lépésük előtt elmondtak egy mondatot az elöre megírt, párbeszédszerü szövegükből. A háttérben kifüggesztett felirat és a hozzá tartozó nyíl pedig az „igazság áramlásának” a haladásukkal ellentétes irányát hirdette. A kijárat felé tartó sor a megismerés newtoni formáiról beszélt, a térről és az időről, melyekkel még Einstein elmélete is egzakt módon összeegyeztethető, s melyektől már határozott elrugaszkodást, más irányú megértést mutat Heisenberg, Schrödinger és Dirac világa, a kvantummechanika. A világ megragadásának newtoni formáit, a teret és az időt ugyanakkor láthatjuk a megismerés kantiánus korlátainak is. Ezt a párhuzamot Einsteinnel vitázva maga Bohr is felveti. Kettejük szemléletmódbeli különbsége kapcsán megemlíti: „[...] [F]igyelemre méltó, hogy még a múlt század kritikai filozófiájának nagy korszakában is csak azt feszegették, hogy megadható-e a tapasztalatok tér- és időbeli rendezésének és oksági kapcsolatainak apriorisztikus megalapozása, s szóba sem került az emberi gondolkodás ilyen kategóriáinak [...] önmagukban rejlő korlátozottsága." [Niels Bohr: Vita Einsteinnel az atomfizika ismeretelméleti problémáiról. In: Uő: Atomfizika és emberi megismerés. Ford. Nagy Tibor. Gondolat, Budapest, 1964. 97. o.] Heisenberg szavaival: „[...] [A] kvantummechanikában matematikailag 
A semmi abszolútumszerủ meghatározásával mintegy erre, a tér és az idő feszélyező problémájára is válaszol az Új adatokban:

1. A fokozódó koncentráció végén a semmi áll.

[...]

1/a A semmi nem lehet valami mellett vagy között, mivel a semmi nem foglal helyet.

formulázott természettörvények nem az elemi részecskékre mint olyanokra vonatkoznak, hanem az elemi részecskékre vonatkozó ismereteinkre. Az a kérdés tehát, hogy ezek az elemi részecskék »mint olyanok « térben és időben léteznek-e, ebben a formában fel sem vethető [...].” [Werner Heisenberg: A mai fizika világképe. In: Uő: Válogatott tanulmányok. Ford. Morlin Zoltán. Gondolat, Budapest, 1967. 25-26. o.] A „klasszikus” fizika és Kant kapcsolata, valamint a tér és az idő a priori felfogásától való elrugaszkodás a kvantumfizika kibontakozásának sürü '20-as éveitől kezdve visszatérő téma volt a fizikusok között. Heisenberg Wolfganggal beszélgetve úgy érvel: „[...] [H]a ezt a naiv időfogalmat meg kell változtatnunk, nem lehetünk biztosak többé, vajon ezután is hasznos szerszámunk marad-e a nyelv és a gondolkozás? És ezt nem azért mondom, hogy visszatérjek Kanthoz, aki szerint az idő és a tér az intuíció a priori formái. Más szavakkal Kant és a régi fizikusok számára az idő és a tér abszolút." [Werner Heisenberg: A rész és az egész. Beszélgetések az atomfizikáról. Ford. Falvay Mihály. Gondolat, Budapest, 1975. 48. o. Ebböl a kötetből lásd hosszabban A kvantumfizika és Kant filozófiája (1931-1934) címü fejezetet: Uo. 157-166. o. De Kant filozófiája rendre felbukkan Heisenberg Fizika és a filozófia című munkájában is: Werner Heisenberg: Fizika és a filozófia. In: Uő: Válogatott tanulmányok. Ford. Kis István. Gondolat, Budapest, 1967. 117. o., 135. o., 138. o. $\mathrm{Az}$ akcióhoz lásd még föként a következőket: Pályi András: Happening és színház. Gondolatok a „Három kvarkot Marke királynak!” kapcsán. In: Színház. 1969. április, II. évf. 4. sz. 46-49. o.; Szőke Annamária: „Titok a jövő jelenléte”. Tudomány a müvészet határain belül Erdély Miklós müvészetében. In: Né/ma? Tanulmányok a magyar neoavantgárd köréböl. Szerk. Deréky Pál és Müllner András. Ráció Kiadó, Budapest, 2004. 246-249. o.; Hornyik Sándor: Avantgárd kvarkok. Erdély Miklós: Három kvarkot Marke királynak. In: Kép - írás müvészet. Tanulmányok a 19-20. századi magyar képzőmüvészet és irodalom kapcsolatáról. Szerk. Kékesi Zoltán és Peternák Miklós. Ráció Kiadó, Budapest, 2006. 7-25. o.] 
1/a A semmi a helyet (a teret) nem elfoglalja, hanem megszünteti.

1/a Nem lehetséges, hogy valami semmivé válik, aztán »egy idő múlva« újra valamivé, mert a semmi nem vesz időt igénybe.

1/a A semmi az időt nem igénybe veszi, hanem megszünteti. ${ }^{134}$

S itt pedig Schelling Bruno-beli abszolútumát idézhetjük: „[...] [A]z abszolút igazság ugyanis magasabb rendü megismerést tételez fel, amelynek az a sajátsága, hogy minden időtől függetlenül és minden időbeli vonatkozás nélkül, önmagában létezik, ennélfogva teljességgel örök.”135

A semmi Erdély Miklósnál a végtelen potencialitás azon abszolút üres helye, amit megérintve a világ újrarendeződhet: „Abszolút koncentráció által a koncentráció tárgya megszünik, majd egy más hígításra ébred.”136 Bibliai reminiszcenciával élve: a mủalkotás által felkínált szabadság a semmiből való teremtés és teremtettség átélésének a lehetősége.

Mert a pillanat mérőlécéhez feszített gerinccel

Semmibe lövetünk s a semmi belénk

\footnotetext{
${ }^{134}$ Erdély Miklós: Új adatok a semmiröl. In: $M K$. 98. o.

${ }^{135}$ F. W. J. Schelling: Bruno avagy a dolgok isteni és természetes elvéröl. Ford. Jaksa Margit. Magyar Helikon, 1974. 11. o. Valamint: „Az örökkévalóság negatív fogalma: nem csak függetlennek lenni az időtől, hanem ugyanakkor mentesnek lenni minden időre való vonatkozástól. Ha tehát az abszolútum nem volna minden tekintetben örök, akkor valamilyen viszony füzné az időhöz.”; „A konkrét körforgás mint olyan csupán a megjelenő világhoz tartozik. A magábanvaló körforgás viszont sohasem időben, hanem csakis az idea alapján előzi meg. Éppígy az abszolútum is csak az idea alapján előz meg mindent, $\mathrm{s}$ nem másképpen.” [F. W. J. Schelling: A müvészet filozófiája. (A kéziratos hagyatékból). Ford. Révai Gábor. Akadémiai Kiadó, Budapest, 1991. 82. o., 84. o.]

${ }^{136}$ Erdély Miklós: Új adatok a semmiről. In: MK. 98. o.
} 
mint az irgalom szilánkja. ${ }^{137}$

Erdély Miklós teóriájában tisztán hallhatóan ószövetségi reminiszcenciák is visszhangoznak: a semmi körülírása a világ semmiből való teremtettségét idézi. A teremtést idézi és mintegy a teológiai vitákat is feleleveníti arról, hogy mi (az) a semmi, amiből a világ teremtetett, arról, hogy mi lehetett a világ előtt. Ám a semmiből való teremtés újra és újra átélésének lehetősége nemcsak a genezis keresztény kontextusát eleveníti fel, hanem zsidó, pontosabban kabbalisztikus haszid zsidó dimenziókba is átvezet.

A világteremtés Jichak Luria Askenázi-féle kabbalista tanát továbbvivő haszidizmus mély gyökereket eresztett Erdély családjában. Erdély Dániel szerint Martin Buber Száz chászid története az édesapja, Erdély Miklós és a nagyapja, Erdély István számára is az egyik legfontosabb könyv volt a házi könyvtárukban. S ez a hagyomány Erdély életmủvének az egyik fontos, fel-felbukkanó kontextusa. ${ }^{138}$ Az 1944-es

\footnotetext{
${ }^{137}$ Erdély Miklós: Fényismeret. In: KO. 88. o.

${ }^{138}$ Erdély Dániel: „Mi kis” életünk. In: Árgus. 1991. szeptember-október, II. évf. 5. sz. 97. o. Erdély egy 1966-ban, Hajdu Andráshoz, Jeruzsálembe írott levelének részlete: „[...] [M]ostanában folyton Martin Bubert olvasom [...]. [Á]ltalában »Buberem« úgy szárítja fel zsidó eredetiségemet, mint a nap a pocsolyát, megnevelt nagyon, de még Apukámat is, képzeld, végre. Nála megtalálható minden gyönyörủen kidolgozva, ami úgy látszott, még nincs kitalálva.” [Erdély Miklós: Levelek Jeruzsálembe. Bevezette és kommentálja Hajdu András. In: Múlt és jövő. 2008. 2-3. sz. 123-124. o.] Amit Hajdu András úgy kommentál: „,...] Miki maga is kereste a katalizátorokat, például az általa sokat említett Bubert, aki a haszidizmussal ismertette meg. Ez a felfedezés csodálattal és lelkesedéssel töltötte el. A népiességnek és egy vakmeröen gondolkozó elitnek olyan dosztojevszkijes keverékét találta itt meg, amelyben felismerhette a saját avantgardizmusának egy korai változatát. Kétségtelenül hasonlított önmaga is valamilyen 150-200 év előtti haszid rabbira, még fizimiskájában is. Nagyon jól el
} 
kiadás előszavában a fordító, Pfeiffer Izsák a következőképpen fogalmaz a luriánus teremtésről, a kezdeti En-Szóf önkorlátozásáról, a cimcumról, a visszahúzódásról, mely üres helyet hagyott a világnak: „[...] [A] végtelen Isten megzsugorította magát, hogy helyet adjon a véges világnak [...], majd a belőle áradó teremtő sugárzás szférák során át létrehozta az érzékelhető mindenséget, melyet Isten szabad cselekvésre engedett. A mindjobban materializálódó teremtés és annak minden részecskéje, mint »héjak«, a tiszta, isteni sugarak börtönei lettek; a »szikrák« elszakadtak ősforrásuktól, számüzöttségbe kerültek, de forrásukhoz tartoznak. [...] Az embernek [...] feladata, hogy az anyagi világban rejlő, számüzött szikrákat kiváltsa, Istenhez váltsa, emelje, hazavigye, a Sechínát Istennel újra egyesítse [...].

tudom képzelni a ber dicsevi Lévi-Jichák vagy a breclávi Rabbi Nachman szerepében.” [Uo. 126. o.] De lásd akár Erdély Baal-Sém Tov homloka a zsámolyon című írását is. [Erdély Miklós: Baal-Sém Tov homloka a zsámolyon. In: KO. 31-36. o. Izrael Baal-Sém Tov a XVIII. században élt, Podóliában, központi alakja volt a haszidizmus megalapításának. Erdély Miklós és a zsidó hagyományok kapcsolatáról Hajdu András dokumentum-összeállításán túl lásd még föként a következöket: Halász András: Közvetítés pohárban. In: Magyar Mühely. 1983. július, XXI. évf. 67. sz. 45-46. o.; William McCagg: A nem-zsidó zsidó a modern Magyarországon. A zsidóság reakciójának felmérése a magyar antiszemitizmusra. „Burzsoá radikálisok”. „Atomtudósok”. „Erdély Miklós”. Esszé a magyar-zsidó koexistencia 1848-1991-ig c. kollokvium céljaira. Kézirat, Batthyány Társaság, Budapest, 1991. október; Kozma György: Kalandor lélek avagy Erdély Miklós ősisége. In: Magyar Mühely. 1999. XXXVII. évf. 110-111. sz. 49-56. o.; Hajdu István: Kalcedon - a kétely, a kétség, a kettősség, a hármasság és a négyesség. In: Magyar Mühely. 1999. XXXVII. évf. 110-111. sz. 156-161. o.; Havasréti József: Széteső dichotómiák. Szinterek és diskurzusok a magyar neoavantgárdban. Gondolat Kiadó - Artpool - PTE Kommunikáció- és Médiatudományi Tanszék, Budapest, 2009. 29-40. o., 215-217. o.] 
Ily módon az ember felelős önmagáért, a világért, Isten országáért."139 A haszidizmus szerint a világ menete nem Isten játéka, hanem Isten sorsa, melyért az ember felelős. Buber összegzésében: „Isten világgá zsugorította össze önmagát, mert Ő, a kettősség és viszonyosság nélkül való egység, akarta, hogy viszonyosság legyen; mert akarta, hogy ismerjék, szeressék, akarják; mert ősegy Létéből, melyben gondolkodás és gondolat egyugyanaz, a másságot akarta kibontakoztatni, amely ismét egységre törekszik. Így sugároztak ki belőle a szférák [...]. A térben-időben érzékelhető világ tehát csak külső leple Istennek, a legkülső, tömör »héj«, azért is a neve »a héjak világa «. ${ }^{140}$ És az ember feladata - melyet akár Erdély montázselméletének kabbalisztikus alapjaként is szemlélhetünk - a szétszóródott isteni szikrák összegyüjtése, az elszakadt sugarak újra egyesítése. Ahogy Buber fogalmaz: „Az ember munkálja Isten egységét, ami annyit jelent: az ő révén megy végbe a létesülés egysége, a teremtés istenegysége - ami természetesen lényege szerint csupán a szétválasztottak egyesítése lehet, mely egység a maradandó szétváltság fölé boltozódik, és kozmikus képe a még szét nem vált lét ősegységének: a sokaság nélkül való egységnek a sokaság egyesítésében.”141

\footnotetext{
${ }^{139}$ Pfeiffer Izsák: Martin Buber. In: Martin Buber: Száz chászid történet. Ford. Pfeiffer Izsák. Magyar Zsidók Pro Palesztina Szövetsége, Budapest, 1944. 14. o., 17. o.

${ }^{140}$ Martin Buber: A chászid-mozgalom teste és lelke. In: Martin Buber: Száz chászid történet. Ford. Pfeiffer Izsák. Magyar Zsidók Pro Palesztina Szövetsége, Budapest, 1944. 32-33. o.

141 Uo. 45. o. Ugyancsak Buber a „nincs állapotát” érintő megújhodás mindennapjairól: „A szakadatlan megújhodás a cáddik igazi életelve. [...] [A] teremtés megtérése a teremtőhöz. [...] Nem egyről beszélik, hogy kemény téli fagyban feltörte a folyó jegét $\mathrm{s}$ alámerült az élő vízben [...]. Ami itt e cselekvésben jelentkezik, az a készség és felkészülés bemenni a »nincs
} 
állapotába «, mert csak azon keresztül teljesítheti ki magát az istenes megújhodás. [...] Megifjúhodott erővel övezetten lát egyre ismét feladatához - napi munkájához: »az egyesítés «, a »jíchud« ezerrétủ munkájához.” [Uo. 44. o.] A mindennapok megszentelése, a szakadatlan megújhodás pedig közvetlen, mondhatni performatív aktussá teszi a teremtés müvészi imitációját is: „[...] [A] kereszténységben (mint a buddhizmusban is) a döntő esemény már megtörtént és már csak »utánozható«, már csak a hozzákapcsolódásban megújítható, már csak megismételhetö; a zsidóságban a döntő esemény mindenkor történik, azaz: most és itt történik.” [Uo. 42. o.]

De érdemes elolvasni a cimcumról Hans Jonas összegzését is: „A cimcum jelentése összehúzódás, visszavonulás, önkorlátozás. A kezdeti En-Szóf, a Végtelen - így a kabbala - visszahúzódott önmagába, hogy helyet adjon a világnak; ezzel lehetővé tette az üresség, a semmi létrejöttét, melyből és melyben megteremtette a világot.” [Hans Jonas: Az istenfogalom Auschwitz után. Zsidó gondolatok. In: 2000. MCMXCVI augusztus, 8. évf. 8. sz. 61. o.] Az En-Szóf és a Semmi (Ayin) kabbalista azonosításáról, és 1530 után az azonosítás egyöntetű elutasításáról pedig lásd: Gershom Scholem: Tíz történetietlen tétel a kabbaláról. In: Gershom Scholem: A kabbala helye az európai szellemtörténetben. Válogatott írások II. Szerk. Adamik Lajos. Ford. Adamik Lajos, Bendl Júlia, Berényi Gábor, Turán Tamás. Atlantisz, Budapest, 1995. 174-175. o. Scholem ugyanitt felvázolja a kabbala egy érdekes hatástörténeti vonulatát is: „Schellingnél föként a cimcum, vagyis a minden teremtést megelőző isteni önkorlátozás Jichak Luria által kidolgozott eszméje kapott filozófiai jelentőséget. Ez az eszme, amely hosszú és figyelemre méltó történettel bír a kabbalán belül, olyasvalami létezésének a lehetőségét állítja, ami már nem Isten, csak akkor gondolhatjuk el, ha ezt a létezést megelőzte Isten magára összpontosításának és magába húzódásának az aktusa. Istennek vissza kell vonulnia önmagába ahhoz, hogy teremtést engedjen ki magából, s e teremtésből a saját szubsztanciája elillant ugyan, de az így keletkezett vákuum mégis megörzött belöle valamit." [Gershom Sholem: A kabbala helye az európai szellemtörténetben. In: I.m. 170. o. Lásd még: Gershom Scholem: A kabbala helye az európai szellemtörténetben. Válogatott írások I. Szerk. Adamik Lajos. Ford. Adamik Lajos, Bendl Júlia, Berényi Gábor, Turán Tamás. Atlantisz, Budapest, 1995.; Rachel Elior: The Paradigms of Yesh and Ayin in Hasidic Thought. In: Hasidism Reappraised. Ed. by Ada Rapoport-Albert. The Littman Library of Jewish Civilization, London - Portland, Oregon, 1997. 168179. o.; Moshe Idel: Martin Buber and Gershom Scholem on Hasidism: A Critical 
A jelentéskioltás lehetősége, az üresség megérintése a pozitív affirmáció egyedüli lehetősége. Ezért Erdély gondolatait, töredezettségüket egybefogva, törekvéseinek nyughatatlan, mindenre kiterjedő dinamikáját kimerevítve akár klasszikus transzcendentál-filozófiának is tekinthetjük. Hiszen ahogy Schelling írja: „Maga a művészet, egész felfogásom szerint nem más, mint az abszolútum kiáradása.”142 S amint Schellingnél az egyes szép az abszolútummal összekötött, úgy Erdélynél az egyedi mủalkotás az önmagát kioltó fragmentáltságán túl a semmire mint abszolút vonatkozási pontra mutat. Ekként lehet számunkra Erdély kivétel azon közkeletü megállapítás alól, miszerint „,...] ami a klasszikus paradigma müveit pontosan körülírja, az értelmezhetetlen az avantgárdban.”143 Erdély

Appraisal. In: Uo. 389-403. o.; Daniel Meijers: Differences is Attitudes to Study and Work between Present-day Hasidim and Mitnaggedim: A Sociological View. In: Uo. 427-438. o.; Tatár György: Az edények széttörése. In: Tatár György: A nagyon távoli város. Vallásfilozófiai írások és viták. Atlantisz, Budapest, 2003. 101-114. o.; Rugási Gyula: A pillanat foglya. Gondolt-Cura Alapítvány Palatinus Kiadó, Budapest, 2002. 225-252. o.; Mezei Balázs: Az önkorlátozó Isten. Bevezető sorok Hans Jonas írásához. In: 2000. MCMXCVI augusztus, 8. évf. 8. sz. 51-55. o.]

${ }^{142}$ F. W. J. Schelling: Bruno avagy a dolgok isteni és természetes elvéröl. Ford. Jaksa Margit. Magyar Helikon, Budapest, 1974. 79. o.

${ }^{143}$ Almási Miklós: Anti-esztétika - Séták a müvészetfilozófiák labirintusában. Helikon Kiadó, Budapest, 2003. 5. o. A múvészet és a müalkotás fogalmának avantgárdbeli kríziséről Rüdinger Bubner azt írja: „A mü kategóriája az esztétikának ama tradicionális meghatározottságai közé tartozik, melyeket a modern müvészet emancipációs mozgalma gyökeresen kétségbevont. A kubizmus és futurizmus konstrukciói, a mindenfajta ready-made-ek és anyag-képek óta a modern produkció egyik leglényegesebb áramlata a hagyományos múegység meghaladását vagy felbomlasztását szolgálja. [...] Végül a mü eszméje ellen elkövetett árulásban buzgólkodnak teljes nyíltsággal azok az akcionista praktikák, amelyek, mint a happening, a müvészetet valamilyen lefolyássá akarják lefordítani [...]. Mindazok az esztétikai jelenségek, amelyek nem a mü mint 
Miklósnál ugyanis a 'műalkotás' neoavantgárd, a mű egész-ségét felbontó, akár önmagát is kiüresítő polarizációja nem merül ki a szövegek és műalkotások közé szóródó töredezettségben. Épp ellenkezőleg: az egymást szétforgácsoló részek a neoavantgárd általános töredezettségén túllendülve organikus egésszé állnak össze, hogy együttesen a semmi mint abszolútum felé mutassanak.

második valóság és az adott világ közötti határvonásra építenek, hanem a határok elmosásával játszódnak, és az elhalványuló definíciók kétértelmüségéből merítik effektusaikat, lényegükhöz tartozónak tekintik a mü zártságával kapcsolatban táplált szkepszist. Azok a törekvések, amelyek a »müvészet« és »élet« között folyékony átmenetet próbálnak teremteni, már olyan területen kísérleteznek, ahol immár nem jut hely a mü kitüntetettségének. [...] [A] mü-fogalom válsága a modern kor lényeges jegye. [...] A mü kategóriáját ugyanis értelmének elvesztése fenyegeti, ha tiltakozás nélkül azt is magába kell foglalnia, ami éppen megszüntetésére vagy felbomlasztására szolgál.” [Rüdinger Bubner: A jelenkori esztétika némely feltételéről. Ford. Mesterházi Miklós. In: Athenaeum. 1991. I. kötet 1. füzet, 172-173 o.] Peter Bürger azonban Bubner megállapításából kiindulva arra a következtetésre jut, hogy a neoavantgárd a történeti avantgárd tapasztalatait felhasználva mégiscsak a müalkotás autonómiáját állítja vissza, még ha ki is szélesíti annak fogalmát: szerinte a neoavantgárd végső soron restaurálja a müalkotás kategóriáját. [Lásd munkájából $A z$ avantgárd müalkotás címü fejezetet: Peter Bürger: Az avantgárd elmélete. Ford. Seregi Tamás. Universitas Szeged Kiadó, Szeged, 2010. 68-97. o.] Ugyanakkor a müalkotás kerek, szerves vagy fragmentált, töredezett, vagy éppen bővülő, kiszélesedő meghatározásain túllépve könyvét a következőkkel zárja: „Kérdés persze, hogy minden hagyomány szabadon felhasználhatóvá válásának állapotában lehetséges-e még egyáltalán egy esztétikaelmélet kidolgozása abban az értelemben, ahogy Kanttól Adornóig létezett, éspedig azért, mert csak egy tárgyterület strukturáltsága teszi lehetővé annak tudományos megragadhatóságát. Ahol a tárgyterület kialakításának lehetőségei végtelenné váltak, nemcsak az autentikus kialakítás létrehozása nehezedett meg radikális módon, hanem annak a tudományos elemzése is.” [Uo. 111. o.] 
Ugyanakkor, lezárásként nem mellözhetünk néhány összegző megjegyzést arról sem, hogy az erőpróbáktól és csavarodásoktól miként foszlik a szál, ami Erdély Miklóst a klasszikus német idealizmushoz köti.

Hegel szerint a müvészet az abszolútum szempontjából közös talajon áll a vallással és a filozófiával. Viszont, amennyire együvé tartozónak véli mindhármat, éppoly határozottan el is választja öket egymástól. A müvészetet az eszme érzéki látszatával, az abszolút szellem közvetlen megjelenési formájával azonosítja, s ezzel éles határt von a müvészet és a filozófia közé. A filozófiát ugyanis a szabad gondolkodással jellemzi, mely a mủvészet érzéki megjelenítését mindössze egy előzetes formaként kezeli, s így bátran kijelentheti róla akár még azt is, hogy többé már nem lehet a legmagasabb módja az igazság megközelítésének.

Hegel esztétikájában a müvészet, a vallás és a filozófia egyaránt az abszolútumra irányul, s „az abszolút szellem három birodalmát csak azok a formák különböztetik meg, amelyekben objektumukat, az abszolútat tudatosítják.” ${ }^{144}$ A művészethez az első forma, az érzéki szemlélet tartozik, melynek lehetőségei ugyan nagyszerűek, ám egyben ki is jelölik birodalmának határait: „[...] [H]a a művészetet egyfelől ilyen nagyra tartjuk, másfelől éppannyira emlékeztetnünk kell arra is, hogy a szellem igazi érdekei tudatosításának a müvészet sem tartalma, sem formája szerint nem a legfelső s abszolút módja. [...] Az igazságnak csak egy bizonyos köre s foka alkalmas arra, hogy a műalkotás elemében ábrázoljuk [...]."145 Hegel szerint a polgári társadalomban az ész már valóságossá, realitássá vált, ígyhát egyszerűen nincs többé szükség a művészet érzéki

\footnotetext{
${ }^{144}$ G. W. F. Hegel: Esztétikai elöadások I. Szerk. Lukács György. Ford. Zoltai Dénes. Akadémiai Kiadó, Budapest, 1952. 103. o.

${ }^{145}$ Uo. 11. o.
} 
közvetítésére: „A müvészet előttünk már nem számít a legmagasabbrendű módnak, amelyben az igazság exisztenciává teremti magát.”146 A harmadik, legteljesebb forma a szabad gondolkodás: „A tudásnak ezt a legtisztább formáját a szabad gondolkodásban kell felismernünk, amiben a tudomány hasonló tartalmat tudatosít maga előtt, s ezáltal a legszellemibb kultusszá válik, hogy a gondolkodás révén elsajátítsa és felfoghassa azt, ami egyébként szubjektív érzéklet vagy képzet tartalma csupán. Ilymódon a filozófiában egyesül a müvészet és a vallás két oldala: a müvészet objektivitása, amely ugyan elvesztette itt a külső érzékiséget, de ezt felcserélte az objektív legmagasabbrendủ formájával, a gondolkodás formájával; - és a vallás szubjektivitása, amely a gondolkodás szubjektivitásáig tisztult.”147

Erdély Miklós törekvéseinek sajátossága pedig az, hogy munkáiban a befogadás folyamata többnyire a gondolkodás formája felé tart, hogy az ürességig tisztulva megtérhessen akár az érzéki szemlélethez is. Azaz, ha Hegel szerint „vallásunknak és észmüveltségünknek szelleme túljutott azon a fokon, amelyen a müvészet az abszolútum tudatosításának legfőbb módja”, ${ }^{148}$ Erdély részéről az idő éppen arra érkezett el, hogy a művészet a számára kijelölt érzéki szemlélet terrénumából az „észmüveltség” és a vallás felé is átcsordulva - a legmagasabb igazságot tudatosítsa. Tudatosítsa, persze azzal együtt, hogy:

[...] a kézzel fogható tudás a kézben hervadozni kezd mint letépett levél csak hasonlatos.

A tudás független

\footnotetext{
${ }^{146}$ Uo. 105. o.

${ }^{147}$ Uo. 106. o.

${ }^{148}$ Uo. 11. 0.
} 
attól amire vonatkozik, mert letépték. ${ }^{149}$

És ez az, ami végső soron Erdélyt leginkább megkülönbözteti a szisztematikusan építkező, precíz elkülönítésekkel rendszert összeállító elődöktől. Az, hogy Erdély mindent behálózó gondolatai, kivételesen érzékeny meglátásai nem egy tökéletesre csiszolt rendszer dermedtségében állnak, hanem a szabadság dinamikájának a rendezettség felé és az onnan mindig el tartó mozgásában. Richard Rorty a szisztematikus és az épületes gondolkodók közt tesz különbséget, s összességében talán ez utóbbi jelzővel illethetjük Erdély Miklóst is: „A szisztematikus filozófusok a tudomány biztos ösvényére akarják terelni szaktárgyukat. Az épületes filozófusok szabad teret akarnak nyitni a rácsodálkozás képességének amire néha a költők képesek -, annak az érzésnek, hogy van új a nap alatt, van valami, ami nem pusztán annak hü leképezése, ami mindig is megvolt [...]." 150

Erdély, miután Hamvas Béláról és Frazerről beszélget Peternák Miklóssal, meglehetősen pontosan foglalja össze mindazt, amit végül is a müvészet céljának tekint: „A müvészetnek nincs [...] más feladata. Amit én avantgardizmusnak nevezek, az szünet nélkül a mágikus, a régi mágikus, a régi, klasszikus tudományos gondolkodás összezavarásával foglalkozik. És a misztikus, új felismerésekre való preparálása, előkészítése a tudatnak, ez a művészet pillanatnyi feladata. Azt hiszem, az, amit én művelek, az kizárólag erre koncentrál.”151

\footnotetext{
${ }^{149}$ Erdély Miklós: Szóról szóra. In: KO. 49. o.

${ }^{150}$ Richard Rorty: A filozófia és a természet tükre. Ford. Fehér Márta. In: Filozófiai figyelö. 1985/3. sz. 64. o.

${ }^{151}$ Peternák Miklós: Beszélgetés Erdély Miklóssal 1983 tavaszán. In: Árgus. 1991. szeptember-október, II. évf. 5. sz. 88. o. A mágikusról, a tudományról és a
} 
Erdély Miklós törekvéseinek kitartó és konok sajátja: úgy mélyed el a gondolkodás lehetetlenségében, hogy reméli, ez az egyetlen út, ahonnan végül mégis felfelé tekinthet. Amint a Metánban írja: „A vitorlázógépével kifulladásig földön futó pilóta csak attól várhatja a levegőbe emelkedést, ha szakadékba zuhan." ${ }^{152}$

misztikusról lásd ugyanebből a beszélgetésből: „Talán ismered ezt az általam javasolt felosztást, ami a Frazer továbbgondolásával alakult ki. Frazer az Aranyágban kifejti, hogy a mágia a tudománynak a megfelelője. [...] Szóval Frazer kifejti, hogy a mágiának a logikája az ugyanaz a logika, ami a tudományé. Csak egy primitívebb változatban. A mágiánál a hasonlóság, az érintkezés, stb., az egymásrahatás, a rész és egész közti összefüggés van jelen, ami egy magasabb rendü formát kap, így a két gondolkodás azonos gyökerü. Mint a spirálnak egy magasabb foka, de egy vonalba esik. A judeo-keresztény és a buddhista gondolkodás? Mind a kettő misztikus gondolkodás, s ez a mágia és a tudomány közé esik, de azoktól teljesen különböző. Az emberek hajlamosak, hogy a mágiát és a misztikát egy kalap alatt tárgyalják, holott a tudományt és a mágiát kellene egy kalap alatt tárgyalni, és a misztikát teljesen külön kezelni.” [Uo.] ${ }^{152}$ Erdély Miklós: Metán. In: MK. 12. o. 


\author{
„A szépség szabad akar lenni...”"153 \\ Pop art, konceptuális müvészet, politikum: Erdély Miklós és \\ Szentjóby Tamás progresszív munkái a ’60-as évek második \\ felében
}

„A válasz mellébeszélés.”154

Erdély Miklós esztétikájának egésze megegyezik a szabadság lehetőségének leírásával: teóriája szerint a jelentéskioltás, azaz a fogalminyelvi-logikai behatároltság szétfeszítése a szabadság elérésének a záloga. A Marly téziseket a következő sorokkal zárja:

- A műalkotás üzenete az üresség, ami a sajátja.

- A befogadó ezt az ürességet fogadja el.

•• A műalkotás helyet készít a befogadóban, amikor üzenetét a befogadó »megérti «.

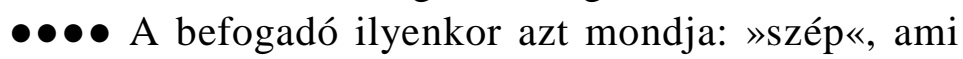
szintén üres kijelentés.

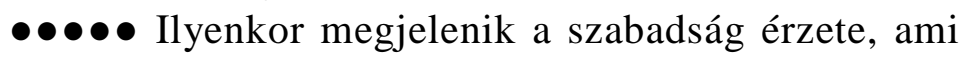
semmi más, mint üresség, lyuk a »felismert szükségszerüség« láncolatában: hely.

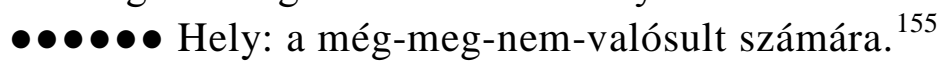

A műalkotás helyet készít elő, helyzetbe lendít, a szabadság minden szükségszerüségtől mentes helyzetébe. A müalkotás a „hirtelen látás" előkészítése, a szabadság utópisztikus teréhez vezető út felkínálása. Itt, a jelentés béklyóitól már megszabadult térben érhető el a szabadság

\footnotetext{
${ }^{153}$ Erdély Miklós: Pop tanulmány. In: MI. 36. o.

154 Sebők Zoltán: Új misztika felé - Beszélgetés Erdély Miklóssal. In: Híd. 1982/3. sz. 371. o.

${ }^{155}$ Erdély Miklós: Marly tézisek. In: MI. 128. o.
} 
semmire és mindenre vonatkozó állapota. A szép a szabadság állapotának jelzése - a müvészet története pedig így a szabadság felé törekvés története.

Erdély Miklós a Pop tanulmányban ír a hányattatásaik során szinte „felismerhetetlenül lerongyolódott” két istenség igazi arcáról:

Először is megsúgták: ők, vagyis a szabadság és a szépség, a két isteni eredetü hölgy, egy és ugyanaz a személy. Látszólagos megosztottságuk egyszerü trükk az ellenség megtévesztésére. A képkeretek cellaablakain mint szépség tekint be ártatlan arccal a szabadság, és fordítva: a szabadságért folyó társadalmi harcokban a szépség akart megnyilvánulni mint forma (életforma). [...] [A]mi szabad, elkerülhetetlenül szép is. [...] A müvészet elgémberedett tagjaival nyújtózkodik. A szépség szabad akar lenni: önmaga. Méginkább: a szabadság szép akar lenni - önmaga - és | mindenre vonatkozni egyszer. ${ }^{156}$

A következőkben ezekből és mégsem egészen pontosan ezekből a gondolatokból szeretnék kiindulni. Mégis: honnan, hogyan, merre haladva?

${ }^{156}$ Erdély Miklós: Pop tanulmány. In: MI. 35-36. o. 


\section{Szelíd, de nem súlytalan}

Erdély Miklós szabadság-elgondolását vizsgálhatjuk a szabadság és az élet klasszikus dichotómiájában elfoglalt álláspontja felől. A következő gondolatfolyam egészen közvetlenül azt a kérdést szeretné megválaszolni: a szabadság Erdély-féle teóriája milyen viszonyban van korának politikai berendezkedésével? Azaz, ha számára a szabadság elsőszámú letéteményese a művészet, akkor pontosabban milyen a müvészetének az öt körülvevő politikumhoz, a szabadság aktuális lehetőségeihez való viszonya? Válaszolni pedig erre csak úgy lehetséges, ha figyelembe vesszük alkotásainak kontextusát - politikumhoz füződő sajátságos viszonyát úgy érthetjük meg árnyaltabban, ha nem csupán az ő alkotásait vesszük sorra, hanem beillesztjük azokat az egykorú müvészet közegébe is. ${ }^{157}$

Erdély Miklós 1981-ben úgy fogalmazott: „A szelíd állapot nem jelenti azt, hogy teljesen súlytalan.”158 A következőkben - immár egészen a disszertációm végéig - az 1960-as évek második felére fogok koncentrálni: azt próbálom majd megmutatni, hogy ennek az időszaknak az avantgárd művészetéhez mérten Erdély Miklós alkotásai közel sem súlytalanok, azonban mégis szelíd állapotot tükröznek. A szelídség persze viszonylagos. Annak bemutatására, hogy mihez képest is szelíd, tömören kitérek majd a

157 Másként hangsúlyozva: „A müvészet csak kontextusként létezik, ez a természete - nincsen más minősége." [Joseph Kosuth: Introduction to Function. In: Joseph Kosuth: Art after Philosophy and After - Collected Writings, 19661990. ed. Gabriele Guerico. The MIT Press, Cambridge, Massachusetts, London, England, 1991. 41. o.]

${ }^{158}$ Erdély Miklós: Apokrif előadás. In: MI. 157. o. 
neoavantgárd kezdeti időszakának csoportos fellépéseire, és közelebbről szemügyre veszem Szentjóby Tamás ekkori munkáit.

Piort Piotrowski In the Shadow of Yalta címü könyvében a magyarországi neoavantgárdról írva a következőképpen összegez: „Magyarország különleges esete a politikailag elkötelezett neoavantgárdnak. A régió más részein a politikai utalások kevésbé voltak direktek vagy szinte teljes egészében hiányoztak. Azt lehet mondani, hogy a magyar neoavantgárd művészek nemcsak hivatkoztak a politikára, hanem közvetlen politikai kritikát gyakoroltak.”159 Piotrowski a régió más országai közül elsősorban Lengyelországra gondol, ahol a viszonylag nagy neoavantgárd korpuszon belül sem lehet politikailag elkötelezett tendenciákat találni. Magyarországon ellenben sorolhatjuk a politikai vélekedésüknek müvészi tevékenységükben gyakran hangot/testet/képet adó alkotókat. Ilyen Attalai Gábor és Pinczehelyi Sándor is. Azért említem először őket, mert a munkáik egy részét meghatározó jelképhasználatot (ötágú csillag, sarló és kalapács) a pop art magyarországi, neoavantgárdba átfolyó jelenlétéhez köthetjük, s Erdély éppen a Pop tanulmányában fogalmaz úgy: „Szokás a pop art-ot a Dada utódjának tartani, de a Dada csak vakaródzott, a pop elvakarta a bolhát.”160 Erdély Miklós számára a

\footnotetext{
${ }^{159}$ Piotr Piotrowski: In the Shadow of Yalta - The Avant-garde in Eastern Europe, 1945-1989. Transl. Anna Brzyski. Reaktion Books, London, 2009. 278. o. Lásd még erről Hajdu István Piotrowskival készített interjúját: Hajdu István: On the Road. prof. Piotr Piotrowski varsói művészettörténésszel beszélget Hajdu István. Ford. Bába Veronika. In: Balkon. 1996/6. sz. 32-35. o. Valamint legalább a következő, a régió törekvéseinek összefüggéseivel foglalkozó kötetet: Postmodernism and the Postsocialist Condition. Edited by Ales Erjavec. University of California Press, Berkeley/Los Angeles/London, 2003.

${ }^{160}$ Erdély Miklós: Pop tanulmány. In: MI. 35. o. Attalai Gábor 1970 telén az Erzsébet híd budai oldalánál a dunaparti lépcsőkre hullott hóból ásta, seperte ki az
} 
ötágú csillag nagyméretű, távolról is kikerülhetetlen, ám az olvadással eltünő, múlékony, negatív alakját (Negatív csillag). 1972-ben, A kultúra azonosítása címen a pop lenyomattechnikáját billogozó gesztussá „honosította”, mikor csillag alakú („Szocialista kultúráért”) kitüntetést préselt saját testére - azaz ismét csak negatív csillagot hozott létre. Pinczehelyi Sándor 1972-ben a pécsi Barbakán mellett zajló útfelújításon ötágú csillagot rakott ki kövekből, majd a motívumot, ahogy a kisvártatva előkerülő sarlót és kalapácsot is, érlelni, variálni kezdte: következetesen vizsgálni, feltorlódott jelentéseiktől megtisztítani, tartalmukat újabb kontextusokban feltölteni. [Lásd a '70-es évekből a következőket: Csillag, köbánya, 1972; Csillag, utcakö, 1972; Csillag, utcakö, 1973; Csillag, 1973; Csillag I-II., 1974; Csillag, rajz, 1974; Csillag, fü, 1979; Csillagnyom, 1979.] Pinczehelyi 1973-ban készítette el ikonikussá váló fotóit, melyeken a különböző szögekben önmaga elé tartott sarló és kalapács mögül mered az objektívre, nyugodt, de erőteljes tekintettel. És ezzel, a szimbólumok alatt talált tárgyak új használtba vételével egy hosszabb folyamat vette kezdetét: fotókkal, fotószekvenciákkal, szitanyomatokkal, akciókkal, videókkal, objektekkel, environmenttel, festményekkel. [A '70-es évekből lásd: Sarló és kalapács I-IIIII., 1973; Sarló és kalapács, 1973; Sarló, 1973; Hengerek I-II-III., 1975; Sarló, video, Graz, 1975; Egy földmüves emlékére, 1977; Földmüvesek emlékére, 1977. Az említett munkákról lásd bővebben: Hock Beáta: Attalai Gábor. (Interjú). In: Balkon. 2001/6-7. sz. 6-8. o.; Hock Beáta: Attalai Gábor. (Részlet a Kállai Ernő ösztöndíj segítségével végzett performansz-kutatási beszámolóból, 2000). Interneten: http://www.artpool.hu/Attalai/Hock2.html; 2012. 02. 03.; Kürti Emese: A csend és az idő - Attalai Gábor (1934-2011). In: Magyar Narancs. 2011. szeptember 1. XXIII. évf. 35. sz. 30-31. o.; Fehér Dávid: Emlékmü hóból. In memoriam Attalai Gábor (1934-2011). In: Élet és Irodalom. 2011. augusztus 19. LV. évf. 33. sz. 22. o.; Hegyi Lóránd: [Bevezetö]. In: Pécsi Mühely 19701980. The Workshop of Pécs. Kiállítási katalógus, Székesfehérvár, Csók István Képtár, 1980. május 11. - augusztus 24. Az István király Múzeum Közleményei, D. sorozat 138. sz., 8-10. o.; Hegyi Lóránd: Pinczehelyi. Pécs, 1995.; Kovalovszky Márta: Pinczehelyi Sándor. Pécsi Galéria és Vizuális Mủvészeti Mühely, Pécs, 2010.; Keserü Katalin: Variációk a pop artra. Fejezetek a magyar müvészetböl 1950-1990. Új Müvészet Kiadó, é.n. 60-61. o.; Piotr Piotrowski: In the Shadow of Yalta - The Avant-garde in Eastern Europe, 1945-1989. Transl. Anna Brzyski. Reaktion Books, London, 2009. 278-281. o.] 
pop art fontos vonatkozási pont: „Pop nem utód - ős.”161 S hogy milyen értelemben tekintheti ősnek? Ahogy írja: „Pop art a megzavarodott emberre rákiabál. [...] A régebbi müvészetek egy kényelmetlen, gyötrő világot igyekeztek elviselhetővé tenni; pop art magát az elégedettséget igyekszik elviselhetetlenné tenni [...]. A pop art a tömegeket saját, kívülről betáplált igényeivel kívánja szembefordítani.”162 A pop art igazi súlyát pedig az jelzi, hogy Erdély ebben a tanulmányában jósolja a következőt: „Nem lehetetlen, hogy a közeljövő legelterjedtebb művészete a tüntetés lesz.»163 Mielőtt azonban túl szorosan egymás mellé helyeznénk a magyarországi neoavantgárdot, a pop artot, a politikai aktivitást és Erdély Miklóst, néhány finomító megjegyzést kell tennünk ezek viszonyáról.

Magyarországon a pop art elöretörése föként azokhoz a müvészekhez köthető, akik a '60-as években eljutottak külföldre világot ${ }^{161}$ Erdély Miklós: Pop tanulmány. In: MI. 35. o.

${ }^{162}$ Uo. 23. o., 28. o.

${ }^{163}$ Uo. 34. o. Peternák Miklós datálása szerint a tanulmány kézirata 1968 júliusa előtt készülhetett. [Peternák Miklós: Szerkesztői jegyzetek. In: MI. 206. o.] Perneczky Géza azonban úgy emlékszik, hogy Erdély már 1964-65 körül leadta feltehetően ezt az írását - a Valóság címü folyóiratnak: „Erdély fura természetű tehetségét kell dicsérnem: honnan a csudából érezte meg - már 1964-65 körül! hogy ez az apokalipszissel kacérkodó kultúr-trockista mentalitás érkezőfélben van? [...] Emlékszem ugyanis, körülbelül ezidőtájt, 64-65 körül történt, hogy hosszabb tanulmányt írt arról, hogy a jövő müfaja, legfontosabb mủvészeti kifejezési eszköze a politikai tüntetés lesz. A cikket aztán leadta a Valóságnak (bumm). Ott láttam én is, noha nem olvastam, csak Sükösd lobogtatta a kezében és olvasott fel belőle néhány mondatot kétségbeesve és engem faggatva, hogy hogy a csudába képzeli a Miki, hogy ezt le lehessen hozni? (Tényleg, hogyan képzelte? [...])” [Perneczky Géza: Produktivitásra ítélve? Az Iparterv-csoport és ami utána következett Magyarországon. 1. rész. In: Balkon. 1996/1-2. sz. 16. o. Egy harmadik, 1967-68-as datálást pedig lásd: Kenedi János: Emberekről, eszmékről, politikáról. Csizmadia Ervin interjúja. 1. rész. In: Valóság. 1990. március, XXXIII. évf. 3. sz. 63. o.] 
látni, tájékozódni, és szembesülhettek a müvészet egyetemes áramlataival. Magyar alkotók első ízben az 1964-es Velencei Biennálén találkozhattak az ott éppen nagydíjat kapó Rauschenberg munkáival. Részben ez a bátorító és felszabadító tapasztalat vezethette őket - Lakner László szavaival - az „élet paradoxonaira reagáló” ${ }^{64}$ müvészet irányába. Azonban a külföldi példákhoz mérten a honi pop art egészen más szerepet tölthetett be. Ahogy Perneczky Géza már 1969-ben rámutatott: a pop art Magyarországon nem reagálhatott sem a tömegkultúrára, sem a müpiacra, hiszen itthon ilyen nem igazán létezett - e helyett az amerikai és angol pop art vizuális megoldásainak és a tárgyakhoz való viszonyának új felületet kellett találniuk. Magukról a mütárgyakról mint árucikkekről pedig Perneczky véleménye az, hogy ez a fajta művészet „emelkedett normákat képvisel, és a veszélye sem fenyegeti annak, hogy árucikké váljon, hiszen még a múzeumok termeiben is csak nehezen kap helyet. A festők és szobrászok számára csak a klasszikus avantgárd magatartásformája járható: a kisebbség laboratórium-munkája, a kísérletezés. Erkölcsileg ez a magatartás igen rokonszenves, a művészet áruba bocsátásánál lényegesen szimpatikusabb [...].”165

Erdély idézett tanulmánya azt jelenti számunkra, hogy az alapkérdésünkre választ keresve semmiképp sem tudjuk megkerülni a honi pop art meghatározásának nehézségeit. Ugyanakkor Pernezckyt olvasva egy

164 Arról, hogy Lakner számára milyen jelentőséggel bírt az utazás, lásd: Beszélgetés Lakner Lászlóval. In: Hatvanas évek. Új törekvések a magyar képzömüvészetben. Kiállítási katalógus, Magyar Nemzeti Galéria, 1991. március 14. - június 30. Összeáll. Beke László, Dévényi István, Horváth György. Szerk. Nagy Ildikó. Képzőmüvészeti Kiadó - Magyar Nemzeti Galéria - Ludwig Múzeum, Budapest, 1991. 134. o.

165 Perneczky Géza: A líraiság és a konstruktivizmus új útjai a magyar festészetben. In: Képzőmüvészeti Almanach 1. Corvina, Budapest, 1969. 54. o. 
következő dilemma is előkerül: ha a magyarországi neoavantgárd a „kisebbség laboratórium-munkája”, mely a múzeumok falain kívül folyik, akkor felmerül a kérdés, hogy utólag ezek a több szálon futó törekvések mennyiben rekonstruálhatóak? A csoportos és egyéni kezdeményezések mennyiben állíthatóak össze a neoavantgárd egyetlen nagy tömbjévé?

Ahogy minden új törekvésnek szüksége van legalább ideiglenes „laboratóriumokra”, kiállítási terekre, presszókra, kávézókra, helyszínekre, ahol szerveződhet, legalább úgy szüksége van egy kritikusra is, aki az egyéni különbségek mögötti közös mozgatóerőt is képes látni. Az egybefogni képes kritikus szerepét Perneczky Géza tudta betölteni ebben az időben. Perneczky - többnyire az Élet és Irodalomban, valamint a Magyar Nemzetben - megjelent kritikáiban érzékenyen, cizelláltan, ugyanakkor következetes értékrenddel fogadta az új törekvéseket. ${ }^{166}$ A helyszínekről mint a törekvések gócpontjairól szólva pedig azt kell megjegyeznünk, hogy ezek a neoavantgárd esetében utólag különösféleképpen felértékelődni látszanak. Az ezernyi szín, a változatos, szinte mindenre nyitott és így sokféleképpen értelmezhető, ráadásul egymással több módon összefüggésbe hozható életművek feldolgozása sokszor - nagyon is bölcsen - a tények, adatok felsorolásában, az alkotások higgadt verbalitásra transzformálásában áll. Mi enyhe mosollyal megjegyezhetjük: a neoavantgárd mozgalmasság, úgy tűnik, még a klasszifikáció számára sem kimerevíthető. Azonban, ha mégis írni szeretnénk róla, a helyszínek azon kivételes dolgok közé tartoznak, amelyek ha nem is biztosan, de legalább

\footnotetext{
${ }^{166}$ Kritikusi tevékenységét az 1970-es, Kölnbe való disszidálása után sem hagyta abba, s a korszak itthon maradt fontos kritikusaihoz hasonlóan az elméletet és a gyakorlatot egymás felé közelítve máig alkotómunkát is folytat mint konceptualista, book artist és mail artist.
} 
valahogy megragadhatóak: ezeknek a felsorolása, egymás mellé füzése a magyarországi neoavantgárd-történet elmesélhetőségének a záloga. Ezért Erdély Miklós munkásságának kontextusát keresve sem tehetünk mást, mint hogy kapaszkodók gyanánt a helyszínekhez, dátumokhoz köthető kezdeti csoportos megjelenéseket összefoglaljuk. ${ }^{167}$

Az új nemzedék egyik első, friss áramlatokat, merész, szabad gondolatokat felvonultató kiállítása a Fiatal Képzőmüvészek Stúdiójának 1966-os tárlata volt. Itt a Lektorátus előzetes zsűrizését kikerülve, három terembe csoportosítva jelentek meg a szürreális, absztrakt és pop artos alkotások. ${ }^{168}$ Két évvel később, 1968-ban, az IPARTERV-kiállításon már

${ }^{167}$ A következőkben több szempontot próbálok majd egyszerre figyelembe venni. A legstabilabb kapaszkodó gyanánt ragaszkodni fogok Erdély munkáinak időrendben való csoportosításához. A feltett alapkérdésünk - mennyiben tekinthetjük politikai, társadalomkritikai munkáknak Erdély alkotásait megválaszolásához nélkülözhetetlen egykorú müvészeti kontextus felfejtésekor szintúgy törekedni fogok a minél pontosabb, akár évekre lebontható egyidejüségre. Viszont a két stabil támponttal élve a célom összességében mégis az, hogy ezekbe kapaszkodva, ám az innen kinyúló indákat végigkövetve Erdély Miklós életmüvének finomabb összefüggéseire és össze-nem-függéseire mutassak rá.

168 Beke László ezt a tárlatot, az Ernst Múzeumbei Stúdió ’66-ot tartja a neoavantgárd első fontos állomásának. Lásd: Beke László: Dátumok a magyar avantgarde-müvészet történetéből, 1966-1979. In: Müvészet. 1980. október, XXI. évf. 10. sz. 20-22. o.; Studió 66. A Fiatal Müvészek Studiójának VI. kiállitása. Kiállítási katalógus, Ernst Múzeum, Budapest, 1966. A zsűrizetlen bemutatókról és arról, hogy Lakner Lászlót az előző, 1964-es tárlaton a zsűri még nem engedte kiállítani, lásd: Sinkovits Péter: Kronológia. In: IPARTERV 68-80. Kiállítási katalógus, Iparterv házi nyomdája, Budapest, 1980. 3. o. Az egyidejü kritikából lásd: Perneczky Géza: Fiatalok stúdiója, 1966. Kiállítás az Ernst Múzeumban. In: Magyar Nemzet. 1966. április 22. XXII. évf. 94. sz. 4. o.; Kerékgyártó István: Stúdió 66. In: Tükör. 1966. április 26. 17. sz. 7-9. o.; Rózsa Gyula: Végletek és távlatok. Fiatal képzőmüvészek az Ernst Múzeumban. In: Népszabadság. 1966. 
szinte teljes spektrumában lépett színre az a friss, dinamikus, fiatal generáció, amely ki akart és ki is tudott tekinteni a provincializmusból. ${ }^{169}$

május 7. XXIV. évf. 107. sz. 7. o.; Szabó György: Fiatalok próbája az Ernst Múzeum-ban. In: Élet és Irodalom. 1966. május 7. X. évf. 19. sz. 3. o.; Passuth Krisztina: A „Stúdió 66” festményeinek kiállítása az Ernst Múzeumben. In: Tiszatáj. 1966. június, XX. évf. 6. sz. 459-460. o.; Németh Lajos: „Stúdió, 1966”. A fiatal müvészek stúdiójának VI. kiállítása. In: Kritika. 1966. június, IV. évf. 6. sz. 49-51. o.; Kovács Gyula: Súdió 66. In: Kortárs. 1966. augusztus, X. évf. 8. sz. 1337-1340. o.; Bolgár Kálmán: Gondolatok a Stúdió 66-ról. In: Müvészet. 1966/12. sz. 45-47. o. A tárlat áttörő szerepéről érdemes elolvasni a résztvevők visszaemlékezéseit is: Beszélgetés Keserü Ilonával. In: Hatvanas évek. Új törekvések a magyar képzömüvészetben. Kiállítási katalógus, Magyar Nemzeti Galéria, 1991. március 14. - június 30. Összeáll. Beke László, Dévényi István, Horváth György. Szerk. Nagy Ildikó. Képzőművészeti Kiadó - Magyar Nemzeti Galéria - Ludwig Múzeum, Budapest, 1991. 139-150. o.; Beszélgetés Fajó Jánossal. In: Uo. 169-174. o. Lásd még: Aknai Katalin - Merhán Orsolya: Belső zsűri. A Fiatal Képzőművészek Stúdiójának története 1958-1978. In: A második nyilvánosság - XX. századi magyar müvészet. Összeállította Hans Knoll. Enciklopédia Kiadó, Budapest, 2002. 200-227. o.; Tiltás és Türés. A Fiatal Képzőmüvészek Stúdiójának 1966-os és 1967-es kiállítása. Kiállítási katalógus, Szerk. Csanádi-Bognár Szilvia. Ernst Múzeum, Budapest, 2006.; Zombori Mónika: Stúdió kiállítások a korabeli dokumentumok tükrében. 1. rész: A hatvanas évek. In: Artmagazin. 2015. XIII. évf. 8. sz. 82. sz. 30-35. o. A hatvanas évek magyar művészetének törekvéseiről lásd még Kovalovszky Márta és Forgács Éva összefoglaló tanulmányait, valamint György Péter írásait: György Péter: Az elsüllyedt sziget. In: Uő: Az elsüllyedt sziget. Képzőmüvészeti Kiadó, Budapest, 1992. 5-46. o.; György Péter: Mostantól fogva ez lesz a múlt. Hatvanas évek. In: Uo. 94-121. o.; Kovalovszky Márta: „Jég és aszály között játszi évszak” - A hatvanas évek. In: A második nyilvánosság - XX. századi magyar müvészet. Összeállította Hans Knoll. Enciklopédia Kiadó, Budapest, 2002. 170-199. o.; Forgács Éva: A kultúra senkiföldjén - Avantgárd a magyar kultúrában. In: Uo. 10-65. o.

169 Kovalovszky Márta szerint ekkorra érett meg az idő, hogy a szórványos próbálkozások után ,a magyar müvészet valóságos küzdőterére törjön be az a fiatal nemzedék, amely arra készült, hogy visszakapcsolja a hazai 
Ez a nemzedék a geometrikus absztrakció, a gesztusfestészet, a hiperrealizmus és az op art mellett már határozottan kötődött a pop arthoz is: Rauschenberg, Oldenburg, Warhol és Segal munkáihoz. A pop artos törekvések ugyanakkor feloldódtak ebben a sokféle hangon megszólaló ellenkultúrában. Beke László figyelmeztet arra: „Első megközelítésre nem érdemes az ilyen helyszíneken rendezett kiállítások stílusbesorolásával, irányzatosságával foglalkoznunk, hiszen az egyik legfontosabb, az IPARTERV volt a legeklektikusabb; a müvészeket nem a stílusigazodás, hanem a korszerüség vágya és az avantgardista magatartás hozta össze.”170

képzőművészetet az egyetemes áramlatok hálózatába.” [Kovalovszky Márta: Uo. 196. o.] Már a kortárs múvészek és az egykorú kritika is IPARTERVgenerációként említi az itt kiállítókat - Hegyi Lóránd mindössze tizenkét év távlatából, 1980-ban már nem is csak a kiállítókat, hanem minden fiatalt, aki számára egy „egész történelmi korszak” vette ekkor kezdetét -, utalva arra, hogy a tárlat helyszíne az IPARTERV Vállalat, teljes nevén Ipari Épülettervező Vállalat Deák Ferenc utca 10. szám alatti irodaházának nagyterme volt. Az IPARTERV néhány év alatt legendává vált, s szinte azonnal megindult a kánonképzés is, az IPARTERV-generációt a „neo-avantgárd” kifejezéssel meghatározva. 1968. december 12-20. között itt állítottak ki: Bak Imre, Frey Krisztián, Hencze Tamás, Jovánovics György, Keserü Ilona, Konkoy Gyula, Lakner László, Molnár Sándor, Nádler István, Siskov Ludmil és Tót Endre. A kiálítás rendezője, a fiatal müvészettörténész, Sinkovits Péter, Kondor Bélát is meg szerette volna hívni, aki végül nem fogadta el az invitálást. [Sinkovits Péter: Kronológia. In: IPARTERV 68-80. Kiállítási katalógus, Iparterv házi nyomdája, Budapest, 1980. 5. o.]

${ }^{170}$ Beke László: Türni, tiltani, támogatni - A hetvenes évek avantgárdja. In: A második nyilvánosság - XX. századi magyar müvészet. Összeállította Hans Knoll. Enciklopédia Kiadó, Budapest, 2002. 234. o. Beke László, habár az egzakt stílusbesorolást problémásnak és nem is éppen a leglényegesebb megközelítésnek látja, idézett tanulmányában azért mégiscsak foglalkozik az irányzatokkal. Egyrészt az egyes alkotók egyéni sajátosságait, a pályájukon történt változásokat is figyelembe véve, másfelől pedig az irányzatok tömbjeit jóval nagyobb 
Az IPARTERV következő, egy évvel későbbi kiállítása még tovább bővült: ekkor csatlakozott a korábbiakhoz Méhes László, Baranyay András, Major János, s ekkorra már megkerülhetetlenül feltünt a színen Szentjóby Tamás és Erdély Miklós is. ${ }^{171}$

folyamba ágyazva. A magyarországi progresszív mủvészet kezdetét 1965 tájékára teszi az első happeningekkel, a politikai jelleget felvevő pop arttal és a '68-tól terjedő, ugyancsak politikai színezetben megjelenő konceptuális müvészettel. [Uo. 229. o.] Körner Éva hasonlóan ír a konceptuális művészetről. Egyfelöl bemutatja annak variabilitását, egyetlen szük keretbe való leszükíthetetlenségét, ugyanakkor a magyart a nyugati konceptuális müvészettel párba állítva ez utóbbinak a sterilitását, a függetlenségét, az előbbinek pedig a politikai karakterét hangsúlyozza. [Körner Éva: Az abszurd mint koncepció. Jelenetek a magyar koncept art történetéböl. I. rész. In: Balkon. 1993/1. sz. 22. o.] A pop art honi jellegét illetően pedig a kategoriális besorolások nehézségének lehet eklatáns példája számunkra Keserü Katalin és Perneczky Géza véleménye közötti feszültség. A Variációk a pop artra címü tárlathoz (Ernst Múzeum, 1993) készült könyvből idézi Perneczky Keserü Katalint: „A pop art [...] valódi underground mozgalomnak volt része Magyarországon. [...] A magyar pop art tehát avantgárd a szó forradalmi értelmében. Csupa ellentmondása annak, ami Nyugaton pop artként definiálható.” [Keserü Katalin: Variációk a pop artra. Fejezetek a magyar müvészetböl 1950-1990. Új Mủvészet Kiadó, é.n., 52. o.] És Perneczky igencsak sarkos véleménye a tárlatról: „Nagyon rossz tanácsadója lennék, ha ehhez a vállalkozáshoz neki sok sikert kívánnék. [...] Ami nincs, azt nem lehet veszélyek nélkül piedesztálra állítani. Utánakapnék tehát, hogy visszarántsam: »Kata, ne csináld!« Mert hiszen olyan ez, mint amikor a gyerek sértettségében világgá megy, és minden fánál megállva leveri: ipics-apacs pop-art.” [Perneczky Géza: Ipics-apacs pop-art. In: Balkon. 1994/2. sz. 12. o., 15. o.]

171 A II. IPARTERV-kiállítás 1969. október 24-én nyílt meg, szintén az IPARTERV építészi tervezőiroda épületében - ott, ahol az első kiállítás előtt két héttel, Do You See What I See? címet adva rendezvényüknek, Szentjóby és Erdély bemutatták akcióikat. Mindenképpen meg kell említenünk a neoavantgárd másik szárnyának képviselőit, a Szürenon csoportosulást is, mely Csáji Attila szervezésében először a XIV. kerületi Kassák Lajos Művelődési Otthonban ismertebb nevén a Kassák Klubban - volt látható 1969. október 2-20. között. A 
résztvevők, ahogy legalábbis a kiállítás Csáji Attilától eredő programszerü elnevezése mutatja, a szürrealizmus és a nonfiguráció mentén alkottak. Kiállítottak itt: Bocz Gyula, Csáji Attila, Csutoros Sándor, Harasztÿ István, Haris László, Ilyés István, Karátson Gábor, Lantos Ferenc, Papp Oszkár, Pauer Gyula, Prutkay Péter, Türk Péter és Veress Pál. [A kiállítás katalógusának utószavát Sík Csaba írta, szórólapján Ungváry Rudolf írása olvasható. A katalógusban és a szórólapon is szerepel Zeisel Magda neve, aki végül nem vett részt a kiállításon. A Kacsóh Pongrác Mủvelődési Ház ekkor, Pauer Gyula ötlete nyomán, illetve az intézményt vezető Don Péter kezdeményezésére vette fel Kassák Lajos nevét, s a kiállításon jelzésként Kassák két festménye is szerepelt. A Mủvelődési Ház homlokzatának feliratát Pauer Gyula készítette el. 1969 októberétől bő két éven át, az engedélyük bevonásáig a Kassák Klub adott otthont a Halász Péter és Koós Anna által szervezett Kassák Ház Stúdiónak is.] A két csoportosulás, az IPARTERV és a Szürenon 1970-ben egyesült, többek ötlete nyomán, főként Csáji Attila szervezésében, az úgynevezett „R”-kiállításon. Ezt a Budapesti Műszaki Egyetem „R” épületében, az R Klubban tartották 1970. december 15-17. között. A kiállítási katalógus előszavát Beke László írta: groteszk fikcióesszéje abban az időben zajlik, amikor a mütárgyáradat már meghaladja a galériák, múzeumok és a közterek befogadóképességét, amikor a müvészet feltartóztathatatlan expanziója már megkérdőjelezi a 'mủvészet' jelentését is. A résztvevők: Bak Imre, Baranyay András, Csáji Attila, Csiky Tibor, Csutoros Sándor, Donáth Péter, Erdély Miklós, Galántai György, Harasztÿ István, Haris László, Hencze Tamás, Ilyés István, Jovánovics György, Korniss Dezső, Lakner László, Lantos Ferenc, Major János, Méhes László, Molnár Sándor, Molnár V. József, Nádler István, Papp Oszkár, Pauer Gyula, Szentjóby Tamás, Temesi Nóra, Tót Endre és Türk Péter. [A kiállítás meghívóján és katalógusában is olvasható Attalai Gábor neve, aki végül nem szerepelt a kiállításon, Nádler István pedig lemaradt róluk, aki viszont igen. $\boldsymbol{R}$. Kiállítási katalógus, Műegyetem R épület, Budapest, 1970. december 15-17. Beke előszavához lásd még: Beke László: Képzőmüvészet 2000-ben? In: Uő: MÜVÉSZET/ELMÉLET - Tanulmányok 1970-1991. Balassi Kiadó - BAE Tartóshullám - Intermedia, Budapest, 1994. Uo. 56-68. o. Az IPARTERVtárlatokhoz lásd még a legutóbbi, 2010-es, párizsi kiállítás katalógusában Fabényi Júlia, Sinkovits Péter és Hajdu István írásait: Fabényi Júlia: Előszó. In: Iparterv csoport - Progresszivitás és illúzió. A magyar avant-garde harmadik nemzedéke. 1968-1969. Kiállítási katalógus, Párizsi Magyar Intézet, Párizs, 2010. 24-25. o.; Sinkovits Péter: Az Iparterv csoport kialakulása és utóélete. In: Uo. 26-28. o.; 
Erdélynek és Szentjóbynak ekkorra már a háta mögött vannak az első happeningek, és már megérintette őket a fluxus és az objektművészet. Közös munkáik mellett összekötötte öket, hogy produktumaikban megvolt a törekvés arra, hogy a müvészet önmagába záródó tere helyett a tágabb világ felé nyissanak. Ugyanakkor mégis nagyban különböztek politikai mondanivalójuk megfogalmazásának mikéntjében. Azt hiszem, ennek felvezetéseként a következő példa jól érzékelteti a kettejük közötti különbséget: 1971-ben Erdély Miklós, Szentjóby Tamás és Lakner László sorra használatba vettek egy Jovánovics György által konstruált gépet, a Mennyezetreszorító szerkezetet. A Mennyezetfeszítésük alapja egy rugós pallóra szerelt rúd volt, melynek segítségével különböző tárgyakat lehetett alapvető funkciójuktól eltérő helyzetbe, a mennyezetre szorítani. A szerkezetet Jovánovics kérésére mindannyiuk otthonába elvitték, azaz mindenki a saját plafonját feszíthette. Erdély épp csak egy ponton nyomta azt: a géppel íjat és nyílvesszőt szorított fel, s a nyílvesszőről madzagon

Hajdu István: Az illúzió progresszivitása. A magyar avant-garde harmadik nemzedéke. In: Uo. 29-31. o. A Szürenon csoportosulás elnevezésről és a kiállítások szervezéséről lásd: Beszélgetés Csáji Attilával In: Hatvanas évek. Új törekvések a magyar képzömüvészetben. Kiállítási katalógus, Magyar Nemzeti Galéria, 1991. március 14. - június 30. Összeáll. Beke László, Dévényi István, Horváth György. Szerk. Nagy Ildikó. Képzőmüvészeti Kiadó - Magyar Nemzeti Galéria - Ludwig Múzeum, Budapest, 1991. 189. o.; Szürenon. Kiállítási katalógus, Kassák Lajos Mủvelődési Otthon, Budapest, 1969.; Szürenon 19691979. Kiállítási katalógus, Szerk. Mezei Ottó. Kassák Lajos Művelődési Ház, Budapest, 1979.; Mezei Ottó: A Szürenon és kisugárzása. In: Ars Hungarica. 1991/1. sz. 65-83. o. Újraközölve: In: Uő: Magyar, európai, modern. Válogatott írások. Vál. és szerk. Andrási Gábor, Pataki Gábor. Argumentum Kiadó, MTA Bölcsészettudományi Kutatóintézet, Müvészettörténeti Intézet, 2013. 261-278. o.; Dokumentumok a Szürenon és kisugárzása című tanulmányhoz. (Összeállította: Mezei Ottó). In: Ars Hungarica. 1991/1. sz. 111-137. o.; Csáji Attila: Billenö idő. Püski Kiadó, Budapest, 2009.] 
egy függőónt lógatott visszafelé. A nyílvessző hegyének vakolatba fúródása így egy komplex erőegyensúlynak csak az egyik mozzanata volt. Ahogy Erdély írja: „[...] [E]gy felszorított íjjal tisztelegtem a törekvés és annak felső határa előtt (alatt), mikor az íj annál inkább feszül, minél erősebben szorítja fel a szerkezet, és a nyílvesszőre kötött súly mennél inkább húzza azt lefelé.” ${ }^{172}$ Erdély mennyezetfeszítését, ha akarjuk, tekinthetjük politikai munkának, ám a létrehozott, szimbolikusan egyensúlyozó, két irányba törekvő konstrukció jóval nyitottabb az értelmezésekre, semhogy kizárólag erre szükíthetnénk le. Egészen másként láthatjuk, ha elolvassuk mellé Erdély következő, 1974-ben megjelent sorait: „Legenda a kézzelfoghatóról. Valaha az égbolt egy pontjára vékony szálat erősítettek, elérhetetlen magasságban. A szál másik vége leért csaknem a föld felszínéig. Időnként az emberek, ha kedvük tartotta, a szál lengő végét megragadták, s erőteljesen megráncigálták. Jóleső megelégedéssel állapították meg, hogy a szál nem enged, a felső beerősítés kiválóan szilárd. Különösebb teherpróbának a vékony szálat nem tették ki, s így sértetlenül megmaradt. Az idők folyamán mindössze az alsó vége maszatolódott össze a sok fogdosástól. Így alakult ki az emberek fogalma a kézzelfoghatóról.”173 Erdély és Szentjóby szemléletmódjának különbségét az mutatja, hogy ugyanarra a rugós szerkezetre, ugyanarra a nyitott müalkotásra milyen tárgyat helyeztek el - hogy mennyire hagyták azt nyitva, avagy mennyire zárták le, kérdőjelek nélkül. Szentjóby Tamás egy Molotov-koktélt feszített a mennyezethez. S hogy a benzines palack funkcióját és müködését is demondstrálja, egy macskát tetetett a rúd közepére, majd elölépett egy pórázon vezetett kutyával, mire a macska menekülni kezdett az egyetlen

\footnotetext{
${ }^{172}$ Erdély Miklós: Önlehallgatás. In: MI. 7. o.

${ }^{173}$ Erdély Miklós: Sejtések II. (10/a.) In: KO. 92. o.
} 
lehetséges irányba, felfelé, majd a rúd végére érve leverte a Molotovkoktélt. ${ }^{174}$

174 Jovánovics György Klaus Groh felkérésére készítette a Mennyezetreszorító szerkezetet az egy évvel később megjelent Aktuelle Kunst in Osteuropa című kötet számára. [Klaus Groh: Aktuelle Kunst in Osteuropa. DuMont Aktuell, Köln, 1972.] Ő egy széket és egy kisasztalt szorított a plafonra, fejjel lefelé, az asztalon egy folyóirattal - az Új Symposion Erdély által is sokat forgatott számával -, mely a címlapról indítva közli Marcuse Értekezés a felszabadításról - Az új szenzibilitás címủ írását. [Herbert Marcuse: Értekezés a felszabadításról. Az új szenzibilitás. In: Új Symposion. 1970/65. sz. 1-5. o.] Lakner László három verziót készített: előbb kedvenc Lukács-kötetét, aztán saját kezét, s végül egy fotót szorított a mennyezethet, mely a könyvhöz kötözött kezét ábrázolja. Szentjóby és Erdély munkájának közel sem egyszerü kivitelezéséről, illetve arról, hogy Erdély, miután elképzelései szerint elkészült a sajátjával, újabb felhangokat megszólaltatva rajta használatba is vette azt - hegedűvonót kért, s az ij feszes húrján játszani kezdett -, Szentjóby Tamás számolt be egy személyes beszélgetésünk során. Ezúton is köszönöm Szentjóby Tamás segítségét és biztató támogatását. A munkákról lásd még főként Jovánovics György visszaemlékezését és müleírását: Jovánovics György: Emlék-képek. Kép-emékek. In: Orpheus. 1992/4. sz. 104-106. o.; Jovánovics György: Mennyezetreszorító szerkezet, 1971. A Mennyezetreszorító szerkezet használatával készült mủalkotások. In: http://labor.c3.hu/jovanovics-gyorgy-mennyezetreszorito-szerkezet-1971/; 2014. 01. 20. Továbbá lásd: Beke László: Klaus Groh könyvéröl és néhány általános problémáról. In: Magyar Mühely. 1974. április, XII. évf. 43-44. sz. 40. o.; Körner Éva: Az abszurd mint koncepció. Jelenetek a magyar koncept art történetéből. II. rész. In: Balkon. 1993/2. sz. 13. o.

Erdély vertikális egyensúlyozásához, a fent és a lent széttartása között megfeszülő íjhoz érdemes még elolvasni a Gúlában című, a '60-as évek elején (de legkésőbb a közepén) készült írását. Az elbeszélő egy gúlához szegődik, melynek tagjai „gúlában aludtak, ettek, az összes tevékenységüket gúlában végezték”. Legfrissebb csatlakozóként a gúla aljára, a földre kerül, ám nem telik el sok idő, és egy reggel arra ébred, hogy már valaki másnak a vállán áll. Meglepetés meglepetést követ, mígnem a következők történnek: „Egy felfedezés révén mégis elviselhetővé vált helyzetem. Úgy okoskodtam, ha a gúla nélkülem is megáll, nem kell nekem folyton tartanom. Ha a felettem lévőkbe csimpaszkodom, engem se 
Erdély Miklós és Szentjóby Tamás alkotói kapcsolata azonban nem ekkor kezdődött: a következőkben vegyük sorra az 1965 és 1970 közötti munkáikat.

kell tartania senkinek, én sem szenvedek az állandó bizonytalanságtól, a talpam sem bicsaklik a verejtéktől sikamlós vállakon. Ha a fölöttem állók lábszáraira ráfonom karjaimat, könnyedén függeszkedem - úgy gondoltam -, csak saját súlyomat kell tartani. Rövidesen világossá vált előttem, hogy a gúlán belül a függeszkedés általános szokás, és bár a szövevényes, szerteágazó rendszert nem tudtam áttekinteni, de érzékeltem, hogy legalábbis nagy körzetben mindenki felfelé csimpaszkodik. Egyáltalán nem értettem, hogy a gúlát így mi tartja. A rendszer viszonylagos stabilitása csodálatosnak tünt. Elragadtatásomban nem tudtam magamon uralkodni, egy ízben el is kiáltottam magam: „Uraim, mi repülünk!« Kiáltásomra messziről hallatszó panaszos nyögések megértették velem, hogy a mi lebegésünk súlyát a rendszer különös átboltozódása folytán távoli szekciók kétszeres erőfeszítéssel viselik. A lebegés iránti elragadtatásom megcsappant, és beláttam, függeszkedni sem könnyebb, és minél följebb vagyok, annál nehezebb: így egyre többen vannak alattam, és azok mind rajtam függnek.” [Erdély Miklós: Gúlában. In: MK. 25-26. o. Az írás keletkezési idejének behatárolásáról lásd: Beke László - Peternák Miklós: Beszélgetés Erdély Miklós írásairól. In: Jelenkor. 1987. november, XXX. évf. 11. sz. 999. o.] 


\section{Erdély Miklós és Szentjóby Tamás}

Erdély és Szentjóby alkotói kapcsolatának kezdete 1966 tájékára tehető. Ebben az évben, egészen pontosan június 25-én, délután 4 órától mutatta be Szentjóby Tamás, Jankovics Miklós és Altorjay Gábor az első magyarországi happeninget Az ebéd (In memoriam Batu kán) címen. ${ }^{175}$ A

${ }^{175}$ Az ebéd már a meghívójában is az első magyarországi happeningnek tartja magát, és ezt az elsőséget nemcsak a korabeli kritika veszi át, de a korszakkal foglalkozó recepció is megerősíti. Habár a tanulmányok, kronológia-kísérletek az esemény helyszíneként többször - az általam felsoroltaknak több mint a fele tévesen Erdély Miklós Virágárok utcai házának pincéjét tüntetik fel, Erdélyt pedig a happening egyik aktoraként jegyzik, a neoavantgárd kronológiájának rekonstrukciói azért abban megegyeznek, hogy Az ebédet mint a magyarországi happeningek kezdetét jelölik meg. Lásd: Kamondy László: Ebéd in memoriam Batu kán. Meditáció az első hazai happeningről. In: Tükör. 1966. szeptember 13. 37. sz. 10-12. o.; M. Z. [Molnár Zoltán]: Happening. In: Élet és Irodalom. 1966. szeptember 24. X. évf. 39. sz. 10. o.; Anik Cs. Asztalos [Körner Éva]: No isms in Hungary. In: Studio International. 1974. March, Vol. 187. No. 964. 111. o.; Beke László: KENTAUR. In: Magyar Mühely. 1978. június, XVI. évf. 54-55. sz. 70. o. Újraközölve: In: Mozgó Film 2. A BBS Mühelykiadványa. Szerk. Forgács Péter. A „K” rovatot szerkesztette: Beke László. Balázs Béla Stúdió, Budapest, 1986. 205. o.; Beke László: Dátumok a magyar avantgarde-müvészet történetéből, 19661979. In: Müvészet. 1980. október, XXI. évf. 10. sz. 20. o.; Beke László: Az emberi test és a médiumok - képzőmüvészet és színház között. In: Uő: MÉDIUM/ELMÉLET - Tanulmányok 1972-1992. Balassi Kiadó - BAE Tartóshullám - Intermedia, Budapest, 1997. 157. o.; Sinkovits Péter: A magyar avantgárd Székesfehérvárból nézve. In: Müvészet. 1988. május, XXIX. évf. 5. sz. 33. o.; Keserü Katalin: A nyelv flörtje a mủvészettel Magyarországon. In: Holmi. 1990. szeptember, II. évf. 9. sz. 1020. o.; Keserü Katalin: Variációk a pop artra. Fejezetek a magyar müvészetböl 1950-1990. Új Müvészet Kiadó, é.n. 30. o.; Peternák Miklós: A magyar avant-garde film. In: F.I.L.M. A magyar avant-garde film története és dokumentumai. Szerk. Peternák Miklós. Képzőmủvészeti Kiadó, 
helyszín Szenes István Hegyalja út 20/b. szám alatti házának tatárkori pincéje volt, de az akció valójában már a kertben megkezdődött: az érkezőket lángoló babakocsi látványa fogadta, benne két foszlásnak indult, egymásba olvadó babával, majd a derékig földbe temetett - máshogy

Budapest, 1991. 25. o.; Körner Éva: Magyar avantgárd - izmusok nélkül. II. rész. In: Új Müvészet. 1994/6. sz. 8. o.; Perneczky Géza: Produktivitásra ítélve? Az Iparterv-csoport és ami utána következett Magyarországon. 1. rész. In: Balkon. 1996/1-2. sz. 13. o.; Perneczky Géza: Produktivitásra ítélve? Az Iparterv-csoport és ami utána következett Magyarországon. 2. rész. In: Balkon. 1996/3. sz. 23. o.; Andrási Gábor, Pataki Gábor, Szűcs György, Zwickl András: Magyar képzömüvészet a 20. században. Corvina, Gyula, 1999. 180. o.; Kovalovszky Márta: „Jég és aszály között játszi évszak” - A hatvanas évek. In: A második nyilvánosság - XX. századi magyar müvészet. Összeállította Hans Knoll. Enciklopédia Kiadó, Budapest, 2002. 192. o.; Dóra Hegyi, Zsuzsa László: How Art Becomes Public. In: Parallel Chronologies. An exhibition in newspaper format. Budapest, 2009. 4-5. o.; Az ebéd (In memoriam Batu kán). HAPPENING Budapest $H$ 1966. The Lunch (In Memoriam Batu Khan). Szerk. László Zsuzsa, St. Turba Tamás. Ford. Polonyi Csaba. Tranzit Hungary Közhasznú Egyesület, Budapest, 2011.; Nemes Z. Márió: Belecsúszni a humuszba. Az ebéd (in memoriam Batu kán) címü happeningről (1966). In: Flash Art Hungary. 2014. III. évf. 2-3. sz. 13. sz. 14-17. o. Valamint a C3 Kulturális és Kommunikációs Központ folyamatosan bővülő adattára: Az 1966-1980 közötti magyarországi avant-garde müvészet kronológia http://www.c3.hu/collection/koncept/index2.html, és az Artpool Múvészetkutató Központ ugyancsak folyamatosan bővülő, a müvészeten túl a tudományos és politikai eseményekre is kiterjedő kronológiája: http://www.artpool.hu/kontextus/kronologia/1963.html. Az ebéd legbővebb és legkomplexebb értelmezését pedig Müllner András adja, Az ebédtől szerteágazva a happening honi elméletének genealógiáját is felgombolyító tanulmányában amihez viszont feltétlenül el kell olvasnunk Szentjóby Tamás megjegyzéseit is. Müllner András: Az első happening. A magyarországi neoavantgárd akcionizmus vázlatos története. In: Né/ma? Tanulmányok a magyar neoavantgárd köréböl. Szerk. Deréky Pál és Müllner András. Ráció Kiadó, Budapest, 2004. 182-204. o.; Krusovszky Dénes, Szabó Marcell, Urfi Péter: Közegészségtelen töredékek (levélinterjú St. Auby Tamással). In: Puskin Utca. 2008/4. sz. 15-24. o. 
mondva underground - Szentjóby Tamás, aki az előtte lévő írógépen írt, azaz a gépelést néha megszakítva kötelet húzott-eresztett, melynek a másik végén többek közt egy lábasba kötözött csirke vergődött. A zürös, szőrös és tollas akció a pincében folytatódott: felgyújtott rózsával, penésztől vastagon beborított, rohadt szecessziós székkel, rozsdás rollerrel és biciklikerekekkel, málló afrikkal, rohadt rafiával, a kötözött csirkével a lyukas edényben, egerekkel, taglóval, fogkrémmel, kenőszappannal, légyfogó papírokkal, rohamsisakkal, óvszerrel, gipsszel és több kiló spárgával. ${ }^{176} \mathrm{~A}$ közönség élményterápiát, az aktorok tárgyakat találtak. Az

${ }^{176}$ Az egymástól némely pontokon eltérő visszaemlékezések kibogozásához, a happening rekonstruálásához a következő forrásokat vehetjük alapul: Gyémánt László filmfelvételét a happeningről, mely az Artpool Mủvészetkutató Központban megtekinthető, Kamondy Lászlónak a Tükörben megjelent írását Zaránd Gyula fotóival, valamint Altorjay Gábor visszaemlékezését. A használt tárgyak, élőlények azonosításához, pontos leírásához ez utóbbit vettem alapul. [Altorjay visszaemlékezését lásd: Tolnai Ottó: Néhány megjegyzés Bori Imre A legújabb magyar líráról címü írásához. In: Új Symposion. 1968. február, 34. sz. 12-13. o. Újraközölve: Altorjay Gábor: The Lunch (In Memoriam Batu Khan). The first happening in Hungary. The Recollection of Gábor Altorjay. In: Parallel Chronologies. An exhibition in newspaper format. Budapest, 2009. 16-17. o.; Altorjay Gábor: Az ebéd (In memoriam Batu kán). Altorjay Gábor visszaemlékezése. The Lunch (In Memoriam Batu Khan). The Recollection of Gábor Altorjay. In: Az ebéd (In memoriam Batu kán). HAPPENING Budapest $H$ 1966. The Lunch (In Memoriam Batu Khan). Szerk. László Zsuzsa, St. Turba Tamás. Ford. Polonyi Csaba. Tranzit Hungary Közhasznú Egyesület, Budapest, 2011. 7-9. o., 42-44. o. Ez utóbbi kiskönyv ezen kívül tartalmazza még Szentjóby Tamás és Altorjay Gábor egy-egy írását, egy interjút Szentjóbyval, valamint a happening előkészületének jegyzeteit, meghívóját és Zaránd Gyula jó néhány fotóját.]

Utólag - meglehetősen abszurd módon - a kultúrtörténet ugyancsak hasznos forrásainak bizonyulhatnak a Belügyminisztérium III/III-as alosztályának kutathatóvá vált dokumentumai is. A jelentéseket természetesen meghatározza 
esemény menete aztán gyorsult fel, hogy az elviselhetetlen hangerővel üvöltő Penderecki Hirosimájának szinte felismerhetetlenül torz hangjaira a happenerek rituálisan kihányták elfogyasztott hideg ebédjüket, a paprikáskrumplit; az akció ekkortól szakadt át eksztatikus káoszba.

keletkezésük sajátságos praxisa: egy jó részük elfogult, felesleges információkat halmoz, vagy éppen félinformációk híg szövetét pecsételi meg; de a jelentések a „tanulmányírók” müvészetelméleti/történeti szakértelemének széles skálájáról is bizonyságot adnak a kifejezetten ostobától az érzékeny, ráadásul jól felkészültig. A Shwitters fedőnevü (ezen a fedőnéven gyüjtötték egybe a Szentjóbyra vonatkozó információkat) dossziéban lévő Összefoglaló jelentés és intézkedési terv ugyan $A z$ ebédet elnagyolva, „müelemzés” nélkül írja le, ám felvezetés gyanánt müfajtörténeti áttekintéssel is szolgál. A későbbi visszaemlékezések egy részéhez mérten ráadásul ténylegesen objektív forrásnak bizonyul: helyszínként a szakirodalomban tévesen elterjedt Erdély Miklós pasaréti házának pincéje helyett a testvére, Szenes István pincéjét jelöli meg, ahogy az ugyancsak fals írásos és szájhagyománnyal szemben, miszerint Erdély részt vett az akcióban, nem tünteti fel őt az aktorok között. Az említett dossziét, valamint még jó néhány, a magyarországi neoavantgárdhoz köthető, titkosítás alól feloldott dokumentumot lásd a C3 Kulturális és Kommunikációs Központ honlapján: http://www.c3.hu/collection/tilos/. Az ügynöki jelentéseknek mint kultúrtörténeti forráscsoportnak a felhasználhatóságáról lásd Eörsi István és Havasréti József eltérő véleményét, valamint Szőnyei Tamás interjúját Peternák Miklóssal és Erdély Dániellel: Eörsi István: A besúgójelentés mint kultúrtörténeti forrásmunka. In: Élet és Irodalom. 2002. november 22. 8. o.; Havasréti József: Szétesö dichotómiák. Színterek és diskurzusok a magyar neoavantgárdban. Gondolat Kiadó - Artpool - PTE Kommunikáció- és Médiatudományi Tanszék, Budapest, 2009. 90-95. o.; Szőnyei Tamás: Tilos művészet. „A kvalitás nem rendőri ügy”. Peternák Miklós, Erdély Dániel. (Interjú Peternák Miklóssal és Erdély Dániellel.) In: Magyar Narancs. 1998. május 7. X. évf. 19. sz. 8-9. o. [E sorok írója is megkapta a kutatási engedélyt az Állambiztonsági Szolgálatok Történeti Levéltárának Levéltári Kutatási Kuratóriumától, miszerint a 2003. évi III. törvény 4. § (3) bekezdésében meghatározott adatokat (a faji eredetre, a nemzeti, nemzetiségi és etnikai hovatartozásra, a vallásos vagy más világnézeti meggyőződésre vonatkozó adatokat is beleértve) anonimizálás nélkül ismerheti meg. Ezirányú kutatását a későbbiekben folytatni tervezi.] 
Káoszba, aminek azért két jól kivehető iránya volt: a kellékek, talált tárgyak durva atomizálása, és a valóságszilánkok új rendbe való, szinte kényszeredett összeállítása. ${ }^{177}$ Altorjay taglót vesz elő, és igyekszik összezúzni az előtte álló bútorokat, majd megkezdődik a mindennek mindennel való összekötözése. Jankovics Miklóst egy ajtókerethez, egy rohamsisakot tollal tömve az arcához, egy biciklikereket egy rollerhez, a szétzúzott asztal és a székek lábait pedig a mennyezethez. Ezek után következik a happening végkifejlete: Szentjóby, Jankovics és Altorjay kérlelhetetlen erőszakkal hajtják végre a happening azon alapelvét, mely szerint az esemény során az aktorok és a nézők közötti távolságnak meg kell szűnnie. ${ }^{178}$ „Rohadt afrikot szórtunk rá [Jankovics Miklósra],

${ }^{177}$ Az összeállítás, egymásra kenés és egymáshoz kötözés az ekkorra megszólaló Beethoven IX. szimfoniájának záró, negyedik tételére, az Örömódára történt. [Gyémánt László felvétele sajnos néma, az Örömóda megszólalásának hozzávetőleges időpontját Altorjay Gábor visszaemlékezéséből tudhatjuk.] Ezzel ellenben Müllner András $A z$ első happening címü tanulmányában az Örömóda hangjainak zengését következetesen a hányáshoz köti. A happening zürös, egymásba átfolyó történéseihez mérten apró különbség ez, de az értelmező számára mégsem elhanyagolható. Hogy miért is? Mert ha Beethoven Örömódáját és Schiller $A z$ örömhöz címü költeményét mint a felvilágosodás, a polgárság erős, reménnyel teli, utópisztikus szimbólumát egy közvetlenségében ugyancsak erős (könnyed, avagy fájdalmas, de feltétlenül megtisztító), blaszfémikus gesztushoz, a hányáshoz rendeljük, akkor ez a találkozás semmiképp sem kerülheti el az értelmezés szükségességét. Ebből pedig Müllner András számára a happenerek schilleri hagyományhoz való ambivalens viszonya bontakozik ki. Ugyanakkor az Örömódának a pincebéli események végkifejletéhez illesztése a happening talán egyetlen olyan eleme, mellyel az nincs destruktív viszonyban - még ha az óda fennkölt, emelkedett, magasztos hangja helyett valami egészen mást is kaptak a résztvevők.

178 Ahogy Allan Kaprow az 1966-ban, pontosan Az ebéd évében megjelent Assemblage, Environmentek \& Happeningek címü mérvadó munkájában írja: „[...] [A] közönséget teljesen meg kell szüntetni. Minden elemet - az embereket, a 
kilószámra spárgákat kötöztünk a kerethez és J.-hez [Jankovics Miklóshoz], a csirke J. nyakában lógott, spárgákat kötöztünk a mennyezetről lógó tárgyakig, a tárgyaktól J.-ig, J.-től a részvevőkig [sic!], összekötöttük őket egymással, J.-vel és a pincével, kevesen voltunk a kötözéshez, ketten próbáltunk hatvan embert összekötni, J.-vel a sorok között botorkáltam, mikor T. [Szentjóby Tamás] összetörte a villanykörtét és sötét lett.”179

A hányásra és az azt követő kapcsolatok hálójára rímelnek Erdély Miklós Molluszkum, Tévedés és Sejtések című fotói. Az 1969 és 1970 között készült sorozaton a földön fekvő Erdély szájából egy meg nem határozható anyag áramlik kifelé, más-más feliratokkal körbevéve: „tévedés”, „sejtés”, „molluszkum”, „Erdély”, valamint az, hogy „nem az fertőzteti meg, ami a szájon bemegy”. A képek egymástól távol álló jelentései, ha nem is oltják ki egymást egészen, de együtt vibrálnak, mígnem a gondolatok tagolt rendje helyett a gondolatok Sejtését, egy sürü, nyugtalan, aktív állapotot kapunk. A képek együttese a megértés egy

teret, az environment különböző anyagait és jellegét, az időt - a happening részévé kell tenni. Így a színházi konvenció utolsó foszlánya is eltűnik. Aki egyszer találkozott már azzal a festészeti problémával, hogy hogyan lehet egy különböző jelenségekből álló képmezőt egységesíteni, annak számára a happening terében létező tétlen embercsoport csak halott tér. Nem különbözik a vászonnak egy pirosra festett halott területétől. A mozgás válasz-mozgásra hív fel, legyen az egy vászon, vagy egy happening.” [Allan Kaprow: Assemblage, Environmentek \& Happeningek. Szerk. Szőke Annamária. Ford. Horányi Attila. Artpool - Balassi Kiadó - BAE Tartóshullám, Budapest, 1998. 59. o.]

179 Tolnai Ottó: Néhány megjegyzés Bori Imre A legújabb magyar líráról címủ írásához. In: Új Symposion. 1968. február, 34. sz. 13. o. Két apró megjegyzés: egyfelöl a közönséget nem nagyon kellett biztatni az aktív részvételre, ami odáig fajult, hogy a hátsó sorokban gyújtogatásba kezdtek, amit valahogy Altorjay oltott el. Másfelöl az aktorok sem nagyon bízták a véletlenre a részvételt: a pincéből való menekülést megnehezítendő a kijáratot kívülről kályhából, babakocsiból - és mi más lehetne még kívül -, poroltóból készült barikáddal torlaszolták el. 
magasabb szintje felé törekvő montázs. A fotókra éppen ezért egy futó pillantásnál többet kell vetnünk ahhoz, hogy sürü, egymáshoz tapadó jelentésrétegeik megfoghatóak legyenek. ${ }^{180}$

Perneczky Géza az Erdély szájából kiömlő habzó váladékot politikai utalásként „a hazugságot kihányó egészséges népi reakciók” aktuális megidézésének véli. ${ }^{181}$ Azonban látnunk kell, a sűrü massza ennél lényegesen nagyobb területen folyik szét - térben és időben is. A Tévedés címü kép a recens blaszfémiánál jóval súlyosabb tartalommal bír, ha azt Erdély egy meg nem valósult filmterve mellé helyezzük. 1962-ben írta meg a Varga Anna dicsérete címü játékfilm-tervet, melyet '63-ban Túlélni címen tovább bővített. Mindkettőben szerepel a jelenet, miszerint 1944 őszén halálra ítélt fiúk állnak szinte felfoghatatlan nyugalomban cigarettázva saját sírjuk szélén, s az agyonlövetésük előtti utolsó percekben közéjük és a puskák közé, a földre veti magát a rabbi: „Iszonyatosan

180 A Tévedés és a Molluszkum fotók az 1969-es II. IPARTERV-tárlat kvázi katalógusában szerepelnek, mely az IPARTERV kiállítások összevont antológiájaként jelent meg 1970-ben, Dokumentum 69-70 címen. A Sejtések pedig az 1980-as Iparterv 68-80 kiállítás katalógusában kapott helyet.

Erdély az 1970-es IPARTERV-antológiába eredetileg nem ezeket a fotókat tervezte beadni, hanem a Schrödingerhez kötődő Eskü című hat fotómunkából álló sorozatát. Hogy végül miért nem ez a sorozat került bele az antológiába, arról majd később - most azt idézem, ahogy Erdély a Molluszkum fotókról fogalmaz: „S akkor ezt kénytelen voltam visszavonni [az Eskü címü sorozatot], s helyettük azokat a bizonyos Molluszkum fotókat beadni, amiben volt egy happening vonatkozás, ami akkor már ismert volt. De a »molluszkum« felirattal, s még volt ott néhány más felirat is, éreztettem, hogy ez nem akar egy szürrealista akció lenni, hanem ez egy gondolat, egy gondolatsor aktív kifejezése, amit nem is lehetne másképp.” [Peternák Miklós: Beszélgetés Erdély Miklóssal 1983 tavaszán. In: Árgus. 1991. szeptember-október, II. évf. 5. sz. 78. o.]

181 Perneczky Géza: Produktivitásra ítélve? Az Iparterv-csoport és ami utána következett Magyarországon. 1. rész. In: Balkon. 1996/1-2. sz. 13. o. 
csúszik-mászik helyettük, könyörög az avarban, tökéletesen tudja, mit kell tennie, habos szájjal, undorítóan kell könyörögnie most másokért, a fiúkért, hogy ők megmenekedjenek a világ szörnyű valóságától, hogy háború van [...].”182 $\mathrm{S}$ ha a fotón nincs is kivégzőosztag, mit is mondhatna az érthetetlen, zavarodott világra a földön fekvő, habzó szájú „Erdély”, mint azt, hogy „tévedés”. 183

Ami pedig a fotókat - és tévedéseket - egybefogni képes, az a Molluszkum. A molluszkum mint az általános relativitás szemléleti modellje, mint a szájat elhagyó meghatározhatatlan valami. Amint Erdély 1983-ban Peternák Miklósnak felidézi:

[...] [A molluszkum a] vonagló koordinátarendszerek Einstein által talált kifejezése. [...] Einstein azt mondja, annyira általánosan akarja megfogalmazni a relativitás-elmélet tételeit, ami nagyobb precizitást igényel, hogy a törvények egy puhatestủ hátára

${ }^{182}$ Erdély Miklós: Varga Anna dicsérete. In: AF. 67. o. Átírva ugyanezt lásd: Erdély Miklós: Túlélni. In: AF. 86. o.

183 Erdély fogalmi besorolást megzavaró munkái körül gyakorta félreértések terjedtek. Beke László erről a fotóról és a gyanú mechanizmusáról elmeséli, hogy „[e]gyesek nem ismervén a müvész nevét, tudni vélték, hogy valamiféle transzilván (!) akcióról van szó [...].” Az „R”-kiállítás néhány hónappal későbbi katalógusában - melynek előszavát Beke írta - a tárlaton résztvevő művészek neve mellett korrekt módon a születésük dátuma, fontosabb kiállításaik, elérhetőségük, címük, telefonszámuk szerepel, két kivétellel. Az egyik Erdély Miklós, akinek a teljes neve legalább egy fátylat félrehúz munkájáról, de a tisztázást rögtön ellenpontozva újabb (hang)súlyt is elhelyez rajta: „Erdély Miklós: Nem az fertőzteti meg, ami a SZÁJON bemegy... MOLLUSZKUM.” A másik igazán renitens Szentjóby Tamás: „Szentjóby Tamás: Dobd ki a degenerált életet, mint a szart! Csinálj helyette másikat!” [A idézetek forrása: $\boldsymbol{R}$. Kiállítási katalógus, Müegyetem R épület, Budapest, 1970. december 15-17. o.n.; Beke László: Erdély Miklós munkássága. Krono-logikai vázlat képekkel 1985-ig. In: Erdély Miklós. Kiállítási katalógus, Óbuda Galéria, Zichy Kastély, 1986. április 11. - május 5. 2. o.] 
rajzolt koordinátarendszer esetében is érvényesek legyenek. A puhatestü, amit molluszkumnak neveznek a biológiában, szüntelenül vonaglik, és ez a vonagló koordináta... Mikor elolvastam, rögtön éreztem, ez müvészet. Ez a tipikus müvészet, ez a vonaglás. ${ }^{184}$

184 Peternák Miklós: Beszélgetés Erdély Miklóssal 1983 tavaszán. In: Árgus. 1991. szeptember-október, II. évf. 5. sz. 78. o. Einsteinnél ez a következöképpen szerepel: „[...] [O]lyan nem-merev vonatkoztató testeket alkalmazunk, melyek nemcsak hogy a maguk egészében tetszőlegesen mozognak, hanem mozgásuk közben alakjukat is tetszőlegesen változtathatják. Az időt órákkal definiáljuk, melyek járásának törvénye tetszöleges, bármily szabálytalan is lehet; ezeket a nem-merev test egy-egy pontjához gondoljuk rögzítve, és csak azt az egyetlen kikötést kell teljesíteniük, hogy a szomszédos órák egyidejüen észlelhető adatai végtelen keveset különbözzenek egymástól. Ez a nem-merev vonatkoztató test, melyet méltán »vonatkoztató molluszkumnak« nevezhetünk, lényegileg egyenértékü a Gauss-féle négydimenziós koordináta-rendszerrel.” És itt egy lábjegyzet következik: „Molluszkum-koordinátarendszert nyerünk, ha pl. egy puhány hátára rajzoljuk a 4. ábra koordinátavonalait. Miközben a puhány testét vonaglásszerüen változtatja, a koordinátavonalak is egyre változnak.” Majd a föszöveg: „Az általános relativitás elve megköveteli, hogy e molluszkumok mindegyike egyenlő joggal és egyenlő sikerrel legyen koordinátarendszerként felhasználható az általános természettörvények megfogalmazásában; a törvények a molluszkum választásától egészen függetlenek legyenek. A természettörvényekre rótt ily messzemenő korlátozásban rejlik az a kutató-erő, amely az általános relativitás elvének sajátja.” [Albert Einstein: A speciális és általános relativitás elmélete. Ford. Vámos Ferenc. Gondolat, Budapest, 1963. 98-99. o.; Albert Einstein: A különleges és az általános relativitás elmélete. Ford. Vámos Ferenc. Pantheon Irodalmi intézet R.-T., Budapest, 1921. 66-67. o. Einstein 1916-os írása már 1921-ben megjelent magyarul Vámos Ferenc fordításában, ám néhány lábjegyzet, többek közt pont a fentebb idézett is kimaradt belőle. Vámos némileg átdolgozott, az elmaradt lábjegyzetekkel kiegészült fordítása - nem sokkal Erdély fotósorozata előtt - 1963-ban, majd 1965-ben, immár nagyobb példányszámban ismét megjelent. A Molluszkumhoz lásd még Szőke Annamária és Hornyik Sándor tanulmányait: Szőke Annamária: „Titok a jövő jelenléte". Tudomány a művészet határain belül Erdély Miklós művészetében. In: Né/ma? Tanulmányok a magyar neoavantgárd köréböl. Szerk. 
Deréky Pál és Müllner András. Ráció Kiadó, Budapest, 2004. 242-243. o.; Hornyik Sándor: A fekete lyukak esztétikája. Kritikai teória és praxis Erdély Miklósnál. In: Balkon. 2006/6. sz. 10. o.]

A molluszkum azonban Erdélynél nem csak ezeken a képeken vonaglik. 1974-ben természettudományos és művészeti kérdéseket egyaránt érintő, egymáshoz közelítő előadássorozatot szervezett a Fiatal Művészek Klubjában Eseményhorizont címen. Szerepelt itt Szabó Árpád (Bizonyítás a természettudományokban és a matematikában), előadást tartott Lipták Tamás (Antieleatica, avagy hogyan kell dialektikusan alkalmazni a matematikát a tudományokban és a müvészetekben), de a meghívottak között volt Perjés Zoltán, aki a fekete lyukakról, valamint Károlyházi Frigyes is, aki pedig elméleti részecskefizikáról beszélt volna. Erdély az elöadássorozatot a relativitáselmélethez és a fekete lyukakhoz egyaránt kapcsolódó Lehetőségvizsgálat címü téziseivel vezette fel: „Feltevés: Lehetőségem van visszatérni a múltba, s valamilyen módon beavatkozhatom az események menetébe [...]." [Erdély Miklós: Lehetőség-vizsgálat. In: MK. 88. o.] A Lehetőség-vizsgálat hosszú szövege Perjés Zoltán egy friss írásából származó idézettel indul. Perjés tudományos ismeretterjesztő cikke a nemrég felfedezett Cygnus XR-1 kettős csillagról tudósít, mely úgy tủnik, megfelel a fekete lyukakról végzett előzetes számításoknak: így a Copernicus keringő csillagvizsgáló adatai alapján egy brit kutatócsoport 1973. november 25-én már ki is jelentette, hogy a Cygnus XR-1 az elsőként felfedezett fekete lyuk. S ha Perjés cikkét tovább olvassuk, kiderül az is, a fekete lyukak kapcsán mit is jelent az Eseményhorizont: „A neutroncsillagok alig terjedelmesebbek a fekete lyukaknál. A másfél naptömegű csillagok csak valamivel sűrübbek az atommaganyagnál (sőt a még nagyobb tömegủek ennyire sem sürüsödnek össze), amikor eljutnak a fekete lyuk állapotába a gravitációs összeomlás során. A Földről nézve csak eddig tudjuk követni a folyamatot, mert ettől kezdve nem jut ki információ a külvilágba. Azt mondjuk, hogy eseményhorizont keletkezett, amely elzárja elölünk a fekete lyukat. [...] Az eseményhorizonton belül a fény már nem terjed külső szemlélő felé, csak a szingularitás irányában. A téridő szingularitása azt jelzi, hogy itt már nem érvényesek az ismert fizikai törvények.” [Perjés Zoltán: Bezárul a tér. In: Delta. 1974. január, 9. o. A fekete lyukakról, az eseményhorizontról és a Cygnus XR-1ről lásd még: Stephen W. Hawking: Az idö rövid története. Ford. Molnár István. Maecenas Könyvek - Talentum Kft., Budapest, 1998. 89-105. o.; Roger Penrose: A császár új elméje. Számítógépek, gondolkodás és a fizika törvényei. Ford. Gálfi 
László. Akadémiai Kiadó, Budapest, 2011. 426-432. o. Arról pedig, hogy a fekete lyukak „olyan létezők, amelyek az ember régi beidegzett gondolkodását teljesen felkavarják, és semmi másra nincs szüksége egy avantgardistának, mint éppen ilyenekre”, lásd még Erdély Optimista elöadását: Erdély Miklós: Optimista előadás. In: MI. 142-143. o.] Erdély az előadássorozatot felvezetve felolvasta a Lehetőség-vizsgálatot, azonban az Eseményhorizontot tulajdonképpen megnyitó akcióját megzavarták, így azt csak részben sikerült véghezvinnie. Az akcióban a molluszkumot egy dunyha molluszkum-jellegével próbálta volna illusztrálni: fejesvonalzóval merőlegest szerkeszteni rá, majd a töltetét, az angionos részt kivéve megmutatni, miként görbül az egyenes, hogyan vonaglik a $90^{\circ}$-osra kiszerkesztett koordináta. A dunna képlékeny molluszkum-szerúsége, és a fejesvonalzó mint nem éppen ruganyos koordináta-rendszer pedig már 1969-ben, ennek az akciónak mintegy az előképeként is megjelenik, mikor is a Virágárok utcai házukban Erdély családja és a hozzájuk érkező vendégek közös akcióban vettek részt. Az Akció külföldi vendégek számára egyik szegmense az volt, amint Erdély Miklós felesége, Szenes Zsuzsa nagy fejesvonalzó társaságában feküdt az ágyon, majd tojásokat paszírozott át egy felvetőkeret húrjai között. De a molluszkumhoz lásd még Erdély két, 1974-ben, a Kollapszus orv.-ban megjelent versét is: Molluszkumok, Kismolluszkum. [Erdély Miklós: Molluszkumok. In: KO. 97-101. o.; Erdély Miklós: Kismolluszum. In: KO. 102. o. Az Eseményhorizonthoz Szőke Annamária és Hornyik Sándor fentebb említett tanulmányain túl lásd még: Hornyik Sándor: Naiv realizmus és „természettudományos koncept”. A modern természettudomány helye Erdély Miklós müvészetében. In: Magyar Mühely. 2004. XLIII. évf. 131. sz. 26-27. o., 40-42. o.; Hornyik Sándor: Avantgárd kvarkok. Erdély Miklós: Három kvarkot Marke királynak. In: Kép - írás - müvészet. Tanulmányok a 19-20. századi magyar képzőmüvészet és irodalom kapcsolatáról. Szerk. Kékesi Zoltán és Peternák Miklós. Ráció Kiadó, Budapest, 2006. 7. o.; Sőrés Zsolt: Ellentmondásvizsgálat. Egy majdani disszertáció expozéja a 21. századból. In: Magyar Mühely. 1999. XXXVII. évf. 110-111. sz. 109-114. o.; Müllner András: A molluszkumnyelv. Természettudomány és avantgárd művészet. In: Parnasszus. 2011. ősz, XVII. évf. 3. sz. 55-56. o. Az Akció külföldi vendégek számára-hoz pedig lásd: Beke László: Erdély Miklós munkássága. Krono-logikai vázlat képekkel 1985-ig. In: Erdély Miklós. Kiállítási katalógus, Óbuda Galéria, Zichy Kastély, 1986. április 11. - május 5. 6-7. o.] 
Erdély Einstein molluszkum-hasonlatát emeli át metaforaként a fotóba, s ez a meghatározhatatlan vonaglás az, ami a sorozatot egybefogni képes, és ami a fotókat nézve több dimenzióba is átvezet bennünket. A szájon kiömlő molluszkum-vonaglás terjed szét keresztény, haszid és spiritiszta dimenziókba is. A „nem az fertőzteti meg, ami a szájon bemegy”-felirat egyszerre vezet minket az Újszövetség és a Száz chászid történet felé. Máté evangéliuma szerint: „Nem az fertőzteti meg az embert, a mi a szájon bemegy, hanem ami kijön a szájból, az fertőzteti meg az embert.” ${ }^{185}$ És ennek párját megtalálhatjuk Buber Száz chászid története között is. A hagyomány szerint a Jehúdi útra küldte rabbi Bunámot, aki néhány társával együtt nyomban fel is kerekedett. A várost elhagyva útjuk egy faluba vezetett, ahol a kocsmáros, a jámborok felett érzett örömében meghívta őket ebédre. Rabbi Bunám szótlan üldögélt, míg társai az asztalra érkező ételeket firtatták: milyen volt a barom, hiba nélkül való volt-e, jól végezték-e a kisózást, s milyen ember lehet a metsző? „Ekkor egy rongyos ruhájú ember [...] szólni kezdett: »Ó, ti chászidok! De nagy hűhót is csináltok, hogy elég tiszta-e az, amit a szátokba vesztek; bezzeg, annak tisztaságára, ami a szátokon kijön, kevesebb gondotok van!« Rabbi Bunám válaszolni akart neki, azonban a vándor-ember, ahogy Élijáhu szokta, már eltűnt. De Rabbi Bunám már értette, mi végre küldte őt útra mestere."186

\footnotetext{
${ }^{185}$ Máté 15,11

${ }^{186}$ Martin Buber: Száz chászid történet. Ford. Pfeiffer Izsák. Magyar Zsidók Pro Palesztina Szövetsége, Budapest, 1944. 70-71. o. Élijáhu, a tüzes szekéren égbe szálló próféta a chászid legendákban gyakran a világot járó égi küldött szerepét veszi magára, aki a Messiás előhírnökeként megtisztítja az arra érdemesek lelkét. A száj megfertőzésével még több helyen találkozhatunk a hagyományos irodalomban, például: Sáb. 33. a.; Váj. r. 24, 7. [Lásd még a fordító, Pfeiffer Izsák jegyzeteit In: Uo. 145. o.]
} 
Ám a szájból kiömlő molluszkumot - és ez már lassan a happeninghez vezet vissza bennünket - láthatjuk a transzállapotban földre rogyott spiritiszta médium ektoplazmájának is. Ugyanis állítólag transzba esésük állapotában a médiumok füléből, orrából és a szájából, illetve egyes esetekben egyéb testnyílásaikból meghatározhatatlan anyag, ektoplazma szivárog kifelé. A pszichoterapeuta Albert Freiherr von Schrenck-Notzing a következőképpen írja le Stanislava P. lengyel médium 1913. június 23-ai szeánszát: „A szájtól a bal kéz irányába egy széles, rostszerü anyag nyúlik lefelé, keresztülhatolva a [fejet takaró] fátylon, mely a szájból kijőve gumószerűen dagad, majd áttetsző mintázatot mutat, s elágazásai révén [...] növényi rostokra emlékeztet.”187 A médium 1913. július 1-i szeánszáról pedig azt írja: „A felső ajkat egy fehér szubsztancia borítja, amely áthatolni látszik a[z arcot fedő] fátylon, kiszélesedve annak külső oldalán. A június 23-ai struktúrához képest itt egy jelentős különbség mutatkozik. Miközben az elöbbi növényi rostokra emlékeztetett, [...] [a mostani] a csipkeszövés szerkezetét hordozza, a széleiken megvastagodó, különböző méretű gyapjúfonalakkal.” ${ }^{188}$ Dr. Chengery Pap Elemér összegzése az ektoplazmáról az 1932-ben alakult Magyar Metapsychikai Tudományos Társaság hivatalos lapjában: „Az ektoplazma többnyire a médium nyálkahártyáiból, vagy vékonyabb börrel fedett testrészeiből szokott kiáramlani. Így pl. a száj-, orr-, fül-, végbél-, vagina-, hónalj-, ujjhegyekből, stb. Ez az anyagszerü »valami« többnyire láthatatlan, de ha

\footnotetext{
${ }^{187}$ Baron von Schrenck Notzing: Phenomena of Materialisation. A contribution to the investigation of mediumistic teleplastics. Transl. E. E. Fournier d'Albe, D.Sc. London, Kegan Paul, Trench, Trubner \& Co. Ltd., New York, E. P. Dutton \& Co. 1923. 257. o. ${ }^{188}$ Uo. 258. o.
} 
látható alakban mutatkozik, akkor fehér, esetleg halványzöldes (foszforeszkáló, önfényű), vagy szürke, barna, sőt fekete színű is lehet.”189

Jó tudnunk, Erdély családjában kitapinthatóan élt a zsidó misztika, a kabbala irodalma; többen erősen hívő misztikus, okkult beállítottságúak voltak. Erdély anyai nagyapja, Óriás Gusztáv a századforduló előtt okkultista kört alapított. Édesapja, Erdély István kiadásra váró teozófiai könyvvé rendezte filozófiai, teológiai, spiritiszta nézeteit. Édesanyja pedig, a nagyfokú spirituális érzékenységgel bíró Óriás Aranka, már a két háború között ismert zsidó spiritiszta médium volt, majd a második világháború után - megmaradva a „kinyilatkoztatásos spiritizmus” követőjének - az elveszett hozzátartozókkal való kapcsolatteremtésben is segített szeánszain. Erdély Dániel szerint édesapja, Erdély Miklós szinte sohasem vett részt a kör szeánszain, ám a meghatározó élményeket mégis megjelenni látja munkásságában: „A jelentéskioltás és állapotkommunikáció elveinek szerintem családi gyökerei vannak. Az ihletettség mint médiumi, azaz közvetítői állapot - ahogy az alkotói transz vagy meditáció - jó esetben egészen a befogadó lényegéig jut el, megnyitva azt. Áteresztővé, hallóvá és látóvá változtatja a közönséget a mester, a médium, a művész vagy a pap.”190

Így pedig Marshall McLuhan mára szállóigévé váló, többnyire rutinból kimondott megállapításának, miszerint „a médium maga az

\footnotetext{
${ }^{189}$ Dr. Chengery Pap Elemér: Az okkult-fizikai ülések lefolytatásánál szükséges tudnivalók. In: Metapsychikai Folyóirat. 1933. március-április, II. évf. 3-4. sz. 68. 0.

${ }^{190}$ Erdély Dániel: „Mi kis” életünk. In: Árgus. 1991. szeptember-október, II. évf. 5. sz. 94. o.
} 
üzenet”, Erdély Miklós esetében sajátságos jelentésrétegei tárulnak fel. ${ }^{191}$ Erdély különösen felszabadult érdeklődése minden kifejezési eszköz iránt, a mindenre nyitott kísérletezései, a burjánzó, szakadatlan megújuló, szinte egybefoghatatlan életmüve nagyszerü példája annak, hogy a megszületett artefactumok egyben új utakat nyitó javaslattételek a médiumok használatára és a médiumok közötti - intermediális - kapcsolatokra. De életműve egyszersmind annak is kivételes példája, hogy bármi lehet médium, akár még az alkotó maga is. A szájából ektoplazmát kieresztő „Erdély” pedig mint spirituális médium, maga a közvetítés: a racionálisan nem összeférő dimenziók egybekötője, az elválasztott világok közötti kapcsolat megteremtője, ha úgy tetszik, maga a montázs, az intermédium. ${ }^{192}$

191 Marshall McLuhan: Understanding Media. The Extensios of Man. Penguin Books, New York, 1964. 23. o.

192 És itt utalnunk kell Beke László sok helyen megírt 1971-es Elképzelés címü projektjére („A mü = az elképzelés dokumentációja”), melybe Erdélytől egy libazsírba áztatott vattát kapott A/4-es lapon, a rá jellemző mozdulattal és egy felszólítással: „Ne különíts el! Ne izolálj!” Beke az 1986-os Erdély Miklóskiállítás katalógusában többek közt azt írja erről: „A leleplezés kínos szorongása tapad hozzá: libazsíros (»kóser«!) vattát használtak a csaló médiumok ektoplazma helyett.” [Beke László: Erdély Miklós munkássága. Krono-logikai vázlat képekkel 1985-ig. In: Erdély Miklós. Kiállítási katalógus, Óbuda Galéria, Zichy Kastély, 1986. április 11. - május 5. 8. o. A (nem) kóser ektoplazmáról lásd: Egy metapsychikus: Az a bárgyu halhatatlan libazsíros vatta! (Levél a szerkesztőkhöz.) In: Metapsychikai folyóirat. 1933. január-február, II. évf. 1-2. sz. 46. o.] A vajákosság leleplezésének Beke által vélt kínos öniróniájához azt füzhetjük még hozzá, hogy Erdély Elképzelése azért mégiscsak úgy funkcionált volna, mint Erdély, az egymás mellett élő szférákat összekötő spiritiszta médium. Beke László ugyanis a projekthez érkező alkotásokat mappába rendezte, s így a kanálnyi libazsírban ázó vatta a körülötte lévő lapokon átszivárogva, mintegy meglehetősen erőteljes, tapintatlan Önösszeszerelő költészetként ragasztotta volna 
És a spiritizmussal hogyan térünk vissza a happeninghez? A legteljesebb ívben úgy, ha még a ’70-es éveknek egészen a végéig átnyúlva megnézzük Erdély két fotómunkáját, majd két írását is. A ’70-es évek elején készítette a Szeánsz és happening címü, négy részből álló fotómunkáját, mely 1972-ben, Klaus Groh könyvében jelent meg: Stanislava P. ektoplazmát öklendező lengyel médiumról és fluxus akciókról készült képeket helyezett egymás mellé, feltünően hasonló, ám részleteiben mégis eltérő formai elemekkel érzékeltetve a mechanizmusok, tudatállapotok közötti különbségeket és a mélyükön meglévő rokonságot. ${ }^{193}$ Néhány évre rá, 1976-ban, a hatvani Expozíció - Fotó/müvészet tárlaton szerepeltek $A z$ ember nem tökéletes címủ kollázs-tablói, ${ }^{194}$ melyek egy Jaspers-idézetet - „Az ember számára nem létezhet semmiféle eszmény, mert az ember nem tökéletes” - körbetapogatva s némileg megcáfolva, a racionálisan nem megtapasztalhatót mégis elérni képes állapotot, és a spiritiszta médium tudata által az ektoplazmán létrehozott fantomképeket

egybe az egymáson sorakozó, ám egymástól mégis távoli Elképzeléseket. Beke a „Ne különíts el! Ne izolálj!” instrukciónak végül nem engedett, a zsírban tocsogó A/4-es papírlapot a vattával együtt nejlontasakba húzta. Érthető, döntenie kellett: vagy az összes, mintegy harminc munka megmarad, vagy Erdélyé veszi át az uralmat. A döntéshelyzetbe kényszerítő er(d)élyes gesztushoz idézzük Bekének még egy - egészen más tárgyban írt, de akár nagyon is ide vonatkozó megállapítását: „A mesterművek sajátossága, hogy totalitásra törnek, agresszív módon háttérbe szorítják a többieket, pusztán azáltal, hogy magukra hívják a figyelmet." [Beke László: A művészet embertelensége (fikcióesszé). In: Uő: MÜVÉSZET/ELMÉLET - Tanulmányok 1970-1991. Balassi Kiadó - BAE Tartóshullám - Intermedia, Budapest, 1994. 172. o.]

${ }^{193}$ Klaus Groh: Aktuelle Kunst in Osteuropa. DuMont Aktuell, Köln, 1972. o.n.

194 Expozició. Fotó/müvészet. Kiállítási katalógus, Hatvany Lajos Múzeum, Hatvan, 1976. október 24. - 1977. január 31. A Hatvany Lajos Múzeum Füzetei No 2., MÉM STAGEK sokszorosító 367/76 
közvetítik. A tablók dupla közvetítésként a megfoghatatlan vizuális reprodukcióit ismétlik meg éteri variációkban. ${ }^{195}$

${ }^{195}$ A sorozatban az elérhetetlen, a túlnan spiritiszta médium általi leképezésének megismétléséhez Erdély a már ebben az évben „felfedezett” indigópapírt is használja, de fantomképet (re)produkál a televízió képernyőjére helyezett fotópapírral is. Ebben a sorozatban is helyet kap a szétáradó ektoplazma: az Eva Carriere néven ismertté vált médium, Marthe Beraud több fotója, melyeket 1909 és 1914 között a paranormális tevékenységekkel foglalkozó pszichoterapeuta, Albert Freiherr von Schrenck-Notzing készített róla. Schrenck-Notzing báró a Phenomena of Materialisation címü könyvében több mint 200 oldalon át foglalkozik Eva C. szeánszaival, majd vizsgálja, elemzi Stanislava P. néhány szeánszát is 1913-ból. A könyv 225 illusztrációt, nagyrészt fotókat tartalmaz, melyek között az Erdély által felhasznált fotók többségét is megtalálhatjuk. A nagy tiszteletnek örvendő Schrenck-Notzing Magyarországon is járt: 1923 októberében előadást tartott a Gólyavárban, majd megnézett egy budapesti médiumot, a néhány hónappal később nemzetközi botrányt kavaró László Lászlót. Le is fotózták, amint a szájából kiömlő ektoplazma lebegni kezd, majd egy csecsemőfej nagyságú emberfejjé változik, apró kis szemekkel, csapzott hajjal, kecskeszakállal. [Dr. Schrenck-Notzing tanár Budapesten. In: Égi Világosság. 1923. november, XXV. évf. 11. sz. 431-434. o.] A honi, nagyobb terjedelmü munkák közül pedig Grünhut Adolf kétkötetes tanulmánygyűjteményét kell feltétlenül megemlítenünk, melyben külön fejezet foglalkozik a szellemfényképezéssel, s tartalmaz is 11 szellemfénykép-reprodukciót. Grünhut Adolf az Égi Világosság című kinyilatkoztatásos spiritiszta folyóiratot kiadó Szellemi Búvárok Pesti Egyletének volt az egyik alapítója, majd elnöke, és nem mellesleg az Erdély család egyik közeli barátja. Grünhut Adolf: Tanulmányok a spiritizmus köréböl. Magnetizmus, szomnambulizmus, mediumizmus. I-II. Szellemi Búvárok Pesti Egylete, Budapest, 1921. A Szeánsz és happening, valamint $A z$ ember nem tökéletes címü munkákhoz lásd még Peternák Miklós következő könyvének, tanulmányának, illetve egy vele készített interjúnak egyegy részletét: Peternák Miklós: A konceptuális müvészet hatása Magyarországon. 1983-85. Interneten: http://www.c3.hu/collection/koncept/help.html; 2012. 11. 23.; Peternák Miklós: concept.hu| koncept.hu. A konceptuális müvészet hatása Magyarországon. The Influence of Conceptual Art in Hungary. Paksi Képtár - C3 Alapítvány, 2014. 51-52. o.; Peternák Miklós: Interdiszciplinaritás. Új médiumok 
Négy évvel később, 1980-ban, a Müvészet folyóiratban publikálta Erdély Moldován Domokos párizsi kiállítása kapcsán írt Babona mint népmüvészet címü kritikáját. Ebben úgy fogalmaz: „Ha nem született volna meg századunk második felében a happening (ezek után helyesebb születés helyett tudatosodásról beszélni), egy babonás cselekvéssor esztétikai értékelésére nem kerülhetne sor, formai szépségét elfedné avíttsága és céltalansága.”196 Erdély szerint a happening szoros kapcsolatban áll a vallással és a babona rituáléival. Ahogy korábban írja, a happening mint a vallás utódja, szertartásos jellegében képes kiemelkedni a hétköznapok megcsontosodott gyakorlatából; a happening egyfajta szabad mozgalmasságba átlendítő, a változás folyamatos örvénye felé nyitó istentisztelet: Istentisztelet a valósághoz. 1969 körül úgy fogalmaz: „[A happening] [n]em titkolt szándéka szerint nemcsak a művészet, hanem a vallás társadalmi funkciójának utódlását is vállalni kívánja. »Istentisztelet a valósághoz.«”197

az elmúlt három évtized magyar müvészetében - vagy kire hatott Erdély Miklós és kire nem? In: A második nyilvánosság - XX. századi magyar müvészet. Összeállította Hans Knoll. Enciklopédia Kiadó, Budapest, 2002. 253-254. o.; Szabó Marcell, Urfi Péter: „Minek nézzem? Látom, hogy jó!” (interjú Peternák Miklóssal). In: Puskin Utca. 2008/4. sz. 16. o. Továbbá lásd: Beke László: Klaus Groh könyvéről és néhány általános problémáról. In: Magyar Mühely. 1974. április, XII. évf. 43-44. sz. 40. o.; Tarjányi Eszter: A szellem örvényében. Universitas Könyvkiadó, Budapest, 2002. 231-237. o.]

${ }^{196}$ Erdély Miklós: Babona mint népművészet. Moldován Domokos filmfotó- és filmobjekt-kiállítása Párizsban, a Chaillot Palotában. (1979. július - 1980). In: MI. 100. o.

197 Erdély Miklós: A happeningről. Istentisztelet a valósághoz. In: Filmvilág. 1999. március, XLII. évf. 3. sz. 10-11. o. Az Erdély jegyzetei között fennmaradt, először 1999-ben publikált írása alapján sejthető, hogy egy hosszabb tanulmány megírását is tervezte a happeningröl, melyben feltehetően külön fejezetet kapott 
S ezzel vissza is térhetünk 1966-ba, a pince sürü kavalkádjába. A teológiát tanuló Altorjay Gábor 1966-ban azt írja: „Minden happening ősképe a szentmise.”198 Szentjóby szerint pedig: „A Happening aktív Environment: a természet-történelemben függésbe kényszerített embert függetlenségbe kényszeríti. [...] A konvenció-határon az egyén a történelmi múlt abszurditása és a lehetséges Happening-jövő között a saját pozícióját ismeri fel. [...] Minőségi ugrássorozat: permanens (eksztázis) forradalom. Eksztatikus egymásrautaltsági paralel-szituáció. Fénytudatállapot.”199

Ott hagytuk abba Altorjay visszaemlékezését, hogy: „Rohadt afrikot szórtunk rá [Jankovics Miklósra], kilószámra spárgákat kötöztünk a kerethez és J.-hez [Jankovics Miklóshoz], a csirke J. nyakában lógott, spárgákat kötöztünk a mennyezetről lógó tárgyakig, a tárgyaktól J.-ig, J.-től a részvevőkig [sic!], összekötöttük őket egymással, J.-vel és a pincével, kevesen voltunk a kötözéshez, ketten próbáltunk hatvan embert összekötni,

volna a „színházi happening”, a „filozófiai vagy didaktikus happening”, valamint az „utcai vagy politikai happening”. [Lásd: Erdély Miklós: A happeningről. Istentisztelet a valósághoz. In: Filmvilág. 1999. március, XLII. évf. 3. sz. 10. o.] 198 Altorjay Gábor: Élet, anyag, happening. In: Magyar Mühely. 2004. 228-129. sz. 15-16. o. Újraközölve: In: Az ebéd (In memoriam Batu kán). HAPPENING Budapest H 1966. The Lunch (In Memoriam Batu Khan). Szerk. László Zsuzsa, St. Turba Tamás. Ford. Polonyi Csaba. Tranzit Hungary Közhasznú Egyesület, Budapest, 2011. 15. o.

199 St. Turba Tamás az idézett szöveghez, A Happeningröl első közléséhez keletkezési dátumként az „1966 (2010)”-es meghatározást szerepelteti, és precízen figyelmeztet arra is, hogy a szöveget 1968-ban két ponton némileg átírta. Az egyik lábjegyzet éppen az imént idézett mondatnál szerepel: eszerint a „permanens eksztázis” '68-ban „permanens forradalom”-ra változott. [Szentjóby Tamás: A Happeningről (részletek). In: Az ebéd (In memoriam Batu kán). HAPPENING Budapest H 1966. The Lunch (In Memoriam Batu Khan). Szerk. László Zsuzsa, St. Turba Tamás. Ford. Polonyi Csaba. Tranzit Hungary Közhasznú Egyesület, Budapest, 2011. 11-12. o.] 
J.-vel a sorok között botorkáltam, mikor T. [Szentjóby Tamás] összetörte a villanykörtét és sötét lett.”200

A pince sötétjében gomolygó sürü provokációt, a csípős füst és a fojtogató zavarbaejtés koreográfiáját többféleképpen próbálhatjuk higgadtan és immár kellő távolságból - értelmezni. Azonban Az ebéd lényegét éppen a bármiféle értelmezést ellehetetlenítő, minden kívülállást maga alá kotró, félhomályban a szőrt visszafelé simító eksztatikus hangulata adja. Ha azért egy valamit mégiscsak ki szeretnénk emelni, akkor elegendő Szentjóby és Altorjay egyszavas összefoglalását felidéznünk a történtekről: „Szentjóby: „És mi a célja a happeningnek? « Altorjay, Szentjóby (röhögve): »A hatalomátvétel.«"201

Persze, ebben a helyzetben nem tévedhetünk nagyot, ha kevésbé vagyunk precízek, kevésbé próbáljuk fixálni, egy pontba süríteni az indulatok felületét. Mi több, meglehet, annál pontosabbak vagyunk, minél kevésbé vagyunk pontosak. Természetesen a „hatalomátvétel” nem forradalmat vagy puccsot implikál, hanem - és talán ez jóval radikálisabb álláspont is annál - bármiféle rendszer, bármiféle stabil állapot, világkép, értékrend ellen lázad. Szentjóby Tamás, ahogy majd látni fogjuk, ekkoriban nagyon is közvetlen, explicit aktuálpolitikai gesztusokkal dolgozik. Ugyanakkor, később ezekre visszaemlékezve jóval tágabb terét nyitja meg az ön- és müértelmezésnek. Egy későbbi, 1973-as, ars poetica-szerü

\footnotetext{
${ }^{200}$ Tolnai Ottó: Néhány megjegyzés Bori Imre A legújabb magyar líráról címü írásához. In: Új Symposion. 1968. február, 34. sz. 13. o.

201 Altorjay Gábor: Az ebéd (In memoriam Batu kán), 1966. június 25. In: A magyar neoavantgárd első generációja 1965-72. Kiállítási katalógus, Szombathelyi Képtár, Szombathely, 1998. 14. o.
} 
munkájáról, a Légy tilos!-ról ${ }^{202}$ 2003-ban a következőképpen fogalmaz: „Ez nem egy mü [...], hanem létszemléleti háttér. Tehát itt most azonnal szeretném tisztázni, hogy ez nem volt kapcsolatban direkt módon azzal a bizonyos 3T-vel [...], hanem sokkal tágabb területre vonatkozott ez a tilosság. Én azt gondoltam és gondolom [...], hogy ez a bizonyos etikai, morális, esztétikai, jogi, gazdasági, kulturális tilalom, ez - ami bennünket a mai nap is körülvesz és a kezdetek kezdetétől körülvesz -, ez fikció, ez egy koholmány, ez egy képzelgésnek a következménye. Feltétlenül egy hatalmi apparátus képzelgésének a következménye, amihez következésképpen semmi közünk. A 3T az egy kisebb halmaz a Légy tilos! programjához képest. A Holdon is légy tilos!”203

Nos, azt hiszem, Az ebéd közvetlen utalásokat többnyire még elkerülő, sürü provokációja Szentjóbynak az az artefactuma, amelyről leginkább elmondhatjuk, hogy benne a mindenre, mindenhová, még a Holdra is kiterjedő Légy tilos!-sal találkozhatunk. Így pedig számunkra ez a happening annak is jó példája, hogy habár keletkezésük felfejthető kontextusában Szentjóby munkái közül jó néhány akár hangsúlyosan politikai müként is kezelhető, az időnek kitéve ezek között is vannak

\footnotetext{
202 A mottója: „Művészet mindaz, ami tilos. Légy tilos!” Lásd: Bényi Csilla, Galántai György, Sasvári Edit: Eseménytörténet 1966-1974. In: Törvénytelen avantgárd. Galántai György balatonboglári kápolnamüterme 1970-1973. Szerk. Klaniczay Júlia és Sasvári Edit. Artpool-Balassi, Budapest, 2003. 151. o. ${ }^{203}$ A beszélgetés 2003. július 10-én hangzott el a Petőfi Rádióban Németh Gábor Szellemjárás. Magyar avantgárd a '70-es években címü müsorában. A beszélgetésben részt vettek még: Sasvári Edit, Haraszti Miklós és Klaniczay Gábor. (Lejegyzés tőlem.)
} 
olyanok, amelyek újra és újra életre kelhetnek, aktualizálódhatnak: olyanok, amelyek végtelenül nyitottak a rekontextualizálások sorára. ${ }^{204}$

De hol van mindeközben Erdély Miklós? Ö ül a pincében. Semmiképp sem úgy, mint az eseményeket szervező egyik happener, hanem esetleg mint egy magát és ezzel egyben a helyzetet is aktivizáló, sőt, azt akár kanalizáló néző: talán néha bekiabál, mit, hová tegyenek a fiatalok. Erdély Miklós 1984-ben Peternák Miklóssal beszélgetve fontosnak tartja megjegyezni, hogy ebben a happeningben nem vett részt, és nem is nála zajlott, ugyanakkor felelevenít egy számunkra fontos, őt mégiscsak erősen a happeninghez kötő eseménysort: „66-ban a Valóságban megjelentettem ezt a bizonyos »Montázséhség«-et, ami manifesztum jellegű volt. [...] [É]s amikor a cikk megjelent, erre jelentkeztek nálam a fiatalok... Szentjóby, Altorjay, stb., akik szintén odáig hagyományos verseket írtak, de valami ebből megütötte őket, hogy itt valami más is lehet..."205

Ha $A z$ ebéd elméleti megalapozását, szövegszerüen felmutatható előzményeit vagy legalábbis a meghatározó közegét keressük, akkor Erdély 1966-os programadó szövegénél, a Montázs-éhségnél kell megállnunk. ${ }^{206}$ Erdély manifesztumáról nem is csupán az ő visszaemlékezésére alapozva 204 Ehhez a gondolatmenethez lásd még: Kürti Emese: "Dezorientáljuk a csapatokat" St.Auby Tamás kiállítása Karlsruhéban 1. Interneten: http://exindex.hu/index.php?l=hu\&page=3\&id=773; 2012. 03. 10.

205 Peternák Miklós: Beszélgetés Erdély Miklóssal 1983 tavaszán. In: Árgus. 1991. szeptember-október, II. évf. 5. sz. 77. o. A közönség soraiból elörevetett instrukciókról lásd azt, ahogy egy későbbi, de még szintén ebben az évben 1966. december 27-én - kivitelezett happeningről Erdély megjegyzi: „Az Aranyvasárnapban sem vettem részt. Csak itt volt az én pincémben, és amikor megakadt Altorjay Gábor, akkor mondtam neki, hogy mit csináljon.” [Uo. 78-79. o.]

206 Erdély Miklós: Montázs-éhség. In: Valóság. 1966/4. sz. 100-106. 0. Újraközölve: Erdély Miklós: Montázs-éhség. In: AF. 95-104. o. 
mondhatjuk, hogy ez az első honi happening genealógiájának az egyik kitüntetett, utólag beazonosítható pontja; erről a kötelékről tanúskodnak Szentjóby Tamás szavai is, melyeket egy 1971-es, Beke László által készített interjúban használ. Szentjóby ugyanis ebben a beszélgetésben Erdély montázs-teóriájának sarkalatos tételeit és jellegzetes szófordulatait veszi kölcsön, avagy vissza: „tettmontázs”, „konkrét valóságban megnyilvánulás”. 207

207 Beszélgetés Szentjóby Tamással. In: Jelenlét. Szógettó. Válogatás az új magyar avantgarde dokumentumaiból. Az ELTE-BTK irodalmi-müvészeti folyóirata, 1989/1-2., 14-15. sz. 255-262. o. (A beszélgetést Beke László vette hangszalagra 1971. március 11-én.) Hogy miért lehet ez Szentjóby részéről „visszavétel”, arról később. Itt meg kell jegyeznünk, hogy Az ebéd szövegszerü környezete két irányba vezet bennünket. Az egyik Erdély írása, a másik pedig Ember Máriának a Film Színház Muzsikában megjelent Happening és antihappening címü írása, amely, ha ugyan élces tónusban is, de legalább közvetít néhány happeninget nyugatról. Érdemes ebbe beleolvasnunk: „[...] [E]z az irányzat - jóllehet irracionalizmusa veszélyességét nem téveszthetjük szem elöl - a testetlen, megfogalmazhatatlan, amorf lázadás torz kifejezője. A mozgalomra jóvátehetetlenül rányomta bélyegét, hogy Amerikában fogant.” Az élces alaphangon, a happeningek helyükre tételén túl azonban a cikk, kis terjedelméhez mérten meglepően sok információval szolgál. Nyugati napilapokból idézve vázolja Salvador Dalì 50 újságíróval, 12 munkással és szelídített párducával tartott happeningjét, valamint a 77 évesen elhunyt J. Kiesler temetésén az özvegy kérésére Rauschenberg által vezényelt happeninget. De felidézi „a happening szépirodalom (mert már ilyen is van) egyik egy felvonásosának, Allan Kaprow amerikai szerző »Söprés «-ének cselekményét” is. (Az ebédhez hasonlóan itt is vergődik egy kakas: a '62-ben, Woodstockban zajlott eseményen Kaprow egy megkötözött, hisztérikussá váló kakast dobott a közönségbe.) Ember Mária ír még egy japán mészárszék-happeningről Frankfurt am Mainból, valamint az ikonikussá váló fotósorozatot kissé eltúlozva, de azért legalább egy mondatban megemlékezik Beuysról is: „Joseph Beuys produkciója rendszeresen azzal végződik, hogy az előadóművésznek elered az orra vére.” [Ember Mária: Happening és antihappening. In: Film Színház Muzsika. 1966. május 13. 18. o.] 
Erdély Miklós programadó, agitatív írásában a montázs és a film régóta várt önmagára találását szorgalmazza: „Elképzelhetetlen, hogy az »igaz müvészetet« a képernyőn unalmas és nagyképű múzeumlátogatások vagy elmosódó komor háttér előtt ünneplőbe öltöztetett szavalatok, vagy a semmiképpen nem televíziószerü koncertek képviselhetik. A televízió egyegy félórás adásban megkezdhetné a montázs nyelvezetének kimunkálását. [...] Egész rövidesen érezhető lenne áldásos visszahatása a mozikban játszott filmeken is. Némely elszáradt elöítélet kiküszöböléséről van csupán szó.”208 Számára a valódi montázs kiművelésének a film a letéteményese: a filmtől várja a montázsban rejlő hirtelen tágulni képes erő berobbanását. Ugyanakkor, ahogy már jeleztem, montázs-teóriáját mégsem tekinthetjük egyetlen területre, a film médiumára történő fókuszálásnak. Montázselmélete már ebben a programadó írásában is jóval kiterjedtebb ennél: a montázséhség szimptómáit véli felfedezni a prózairodalomban, a költészetben, a zenében, a festészetben és a fotóművészetben is. Egyetlen

Ennek a cikknek a beazonosítását ugyancsak mindkét irányból, Erdély és Szentjóby felöl is elvégezhetjük. Én itt Erdélyt idézem, ugyanis az ő megfogalmazása egyfajta magyarázatot is ad a happeningtől való elhatárolódására: „[...] [N]emcsak azért jelentkeztek ezek a fiatalok, mert olvasták a Montázséhséget, hanem olvasták az újságban azt, hogy happening... valami bulvárlapban akkor lejött és ezt hozták - hogy van happening. [...] Szóval nagyon tiltakoztam az első happening-nek a szelleme ellen, mert jellegzetes másolata volt az ismert elemeknek. Tehát a szürrealisztikus happening akkor divatban volt, én viszont végig a konceptuális akciók mellett voltam.” [Peternák Miklós: Beszélgetés Erdély Miklóssal 1983 tavaszán. In: Árgus. 1991. szeptember-október, II. évf. 5. sz. 78. o.] Erdély itt azt a különbséget hangsúlyozza, hogy ő, az utólag talán inkább performance-nak nevezhető konceptuális akcióiban többnyire egy gondolatból indult ki, s azt próbálta nagy erőket mozgósítva, a tárgyak mellett szinte mindig a nyelvet is felforgatva kifejteni.

${ }^{208}$ Erdély Miklós: Montázs-éhség. In: AF. 96. o. 
példát kiemelve: „És legújabban a lenézett és diadalmas pop-art kétségbeesett s néha könnyelmü erőfeszítéseket tesz, hogy megteremtse a statikus tárgymontázst, összeszerelt tárgyak béna kifejezőerejét veszi igénybe. Mintha szintén a mozi helyett tevékenykedne, olyan leleményességgel, ami a filmekből jócskán hiányzik." ${ }^{209}$ Erdély az éhség hathatós enyhítését a filmtől várja, ám közben montázs-teóriáját oly mértékben terjeszti ki, hogy a különböző müvészeti ágakon belül zajló formaváltásokat is képes a 'montázs' fogalmával magyarázni. S mindez hogyan kapcsolódik az első happeninghez? Erdély egyik célkitüzése az, hogy a rátelepedő „mázsás szimbolikától” megszabadítsa a montázs testét. Elérni ezt pedig szerinte kizárólag „tiszta realitással” lehet. ${ }^{210}$ „A montázs rendelkezzen a rémület gyorsaságával, mintha az utolsó számbavétel lenne, a fölismerő tudat kapkodása véglegesen meghatározó egybevetés. A szétdarabolt valóság legyen ráilleszthető az asszociáció rekeszes futószalagjára, illeszthetősége folytán alapos, közvetlenül ható, és nem csak foltokban tapadó hasonlatosság.”211

A Montázs-éhség körül a kapcsolatok kompex hálója szövődik. Olyan szövege ez Erdélynek, mely a talált tárgy poétikának montázs-ruhába öltöztetésével a neoavantgárdot összeköti a klasszikus avantgárd törekvésekkel. Ezt a szöveget tudjuk felmutatni mint a korai magyar happeningeket átfogó elméleti keretet. Ez az a szöveg, ami felől Az ebédet montázsként láthatjuk, ${ }^{212}$ és ebből a szövegből kinyúlva köthetünk mi is:

\footnotetext{
${ }^{209}$ Uo. 99. o.

${ }^{210}$ Uo. 103. o.

${ }^{211}$ Uo. 104. o.

${ }^{212}$ Az ebéd, főként ha kiadós, a Montázs-éhséget csillapítja, de Erdély írása és Szentjóbyék happeningje Kaprow elvárásainak is eleget tesz. Kaprow ugyanis a happeninget „kaleidoszkópszerü” mintában írja le, miszerint „az események
} 
kollázs-assemblage módszer szerinti szembeállítása legtöbbjükben érvényesül”. Hosszabban idézve: „Egy happening kompozíciója pontosan úgy folyik, mint egy assemblage-é vagy egy environmenté; vagyis meghatározott idötartamok alatt meghatározott terekben zajló események kollázsából alakul ki.” [Allan Kaprow: Assemblage, Environmentek \& Happeningek. Szerk. Szőke Annamária. Ford. Horányi Attila. Artpool - Balassi Kiadó - BAE Tartóshullám, Budapest, 1998. 49. о., 62. o.]

És itt két irányban is megjegyzéseket kell tennünk, mert az előzmények, utózmányok rekonstruálásakor, egy hatástörténet összeállításakor, úgy tünik, bármennyire is próbálunk precízek lenni, csak igazságtalanok lehetünk. Nehéz helyzetben vagyunk. Pontosabban két nehéz alkotó között vagyunk, szorongatott helyzetben. A Montázs-éhséget ugyanis Erdély 1983-as, egyértelműen fogalmazó interjúját követve Müllner András is $A z$ ebédhez köti, mintegy Az ebéd elméleti megalapozásának tekinti. Szentjóby Tamás azonban meglehetős vehemenciával utasítja el mind Müllner „diákos igyekvését”, „tárgyi és elvi aberrációit”, mind Erdély genealógiáját. Ö úgy emlékszik, valóban olvasták Erdély tanulmányát, de csak később, a happening után, amit még annyival told meg, hogy „a »montázs« szót, ill. a »konkrét valóságban megnyilvánulás« kifejezést nem Erdély találta ki, viszont a »tettmontázs« szót én. Brahmahaha!” Ugyanitt Szentjóby kérlelhetetlen mozdulatokkal kavarja fel a recepció lassan megnyugvó történetét több közös erőfeszítésükről vagy épp Erdély munkáiról. Szentjóby Tamás, Stjauby Tamás, Emmy (Emily) Grant, St. Aubsky, T. Taub, St. Auby Tamás, St.Auby Tamás, St. Turba Tamás stb., nem-művészet-művész, felfogásához híven, a művészetet a müvészettörténettől sem elválasztva, a recepció fakkokba rendező mozdulatai láttán felháborodásában nemcsak kiigazítja azokat, hanem el is lehetetleníti. Fellép a „hivatásos müvészettörténet-hamisítók, a hamisan tanúskodók, a rágalmazók” ellen mint a TNPU szuperintendánsa, a NETRAF /Neo-Szocialist.a Realist.a TNPU Globális Kontra-Müvészettörténet-Hamisítók Frontja/ ügynöke. Ahogy pedig köznyelven megfogalmazza: „[...] [M]egpróbálok elhatárolódni egyrészt annak a bizonyos »müvészeti, kulturális közegnek a rekonstrukciójától«, mivel ez, szerencsénkre, lehetetlen [...].” [Az idézetek forrása: Krusovszky Dénes, Szabó Marcell, Urfi Péter: Közegészségtelen töredékek (levélinterjú St. Auby Tamással). In: Puskin Utca. 2008/4. sz. 18. o., 21. o., 22. o.]

Ám be kell vallanunk, Erdéllyel is már-már zavarba ejtő helyzetben vagyunk. Mondjuk úgy, a '80-as évekből több olyan képet hagyott magáról, melyeket immár hiába forgatunk: nagyszerü érzékkel éppen úgy helyezkedik el 
Schiller versét, az újrakötés, az emberiség egységesülésének utópisztikus ódáját a spárga neoavantgárd, vehemens használatához. ${ }^{213}$

rajtuk, hogy erős testalkata a lehető legnagyobb árnyékot vesse maga mögé. Szentjóby és Erdély között, két oldalról szorongatva pedig eltünődhetünk a történeti igazság és az anekdoták közötti összefüggésekről - ami közelebbről a változó kapcsolatukat, néhol az összeférhetetlenségüket, másutt a felcserélhetőségüket, összességében pedig a jótékony, mozgásban tartó, dinamikus viszonyukat mutatja. Ami biztos, Szentjóby megjegyzéseitől és Erdély ön-interpretációitól, saját maga történetének megképzésétől eltekintve is joggal olvashatjuk úgy a Montázs-éhséget mint a fluxus-szerủen gomolygó, kimerevíthetetlen törekvéseket magyarázni tudó szöveget, sőt, akár még a recepció széttartó irányait is egybefogni képes elméletet. Persze, a Montázs-éhség mintha mindig csak arra várna, hogy újabb tárgyakat kebelezzen be, mígnem a helyzet megfordul, s végül csak bajosan válaszolhatunk arra a kérdésre, mi maradt, ami nem montázs.

213 Erdély Miklóstól sem idegen a spárga használata. 1979-ben az INDIGO csoporttal meghívást kapott a Budapesti Nemzetközi Szemiológiai Kongresszus szervezőitől arra, hogy a rendezvény keretein belül tartsanak egy, a konferencia témájához illeszkedő bemutatót, s habár a szervezők később ettől elálltak, a kiállítás mégis megvalósult. Müvészkijárat címen megtartott bemutatójuk a következő eseménysorral zárult: „Egy üveglapra erősített felszúrt friss tejeszacskóból szivárgó cérnavékony tejcsík szánalmas utánpótlást biztosított, és az aludttej alól kihúzott több kilométernyi valódi cérnával érezhető kapcsolatot tartott. Egy iratszekrény fiókjából nehézkesen szénából és tejből kiszürt varrótüket a közönségnek szétosztottuk azzal a meghagyással, hogy az aludttejtől lucskos cérnaszálat sorban füzzék bele, hogy a kommunikáció nyomorúságát és az egymásrautaltságot egyaránt megjelenítsük. Majd erre az egyetlen cérnaszálra fölfüzött társaságot arra biztattuk, hogy egy elkerített teremrészben a homokkal töltött tejeszacskókat varrja be.” [Erdély Miklós: Müvészkijárat (1979. június). In: KGYFI. 240-241. o.]

És a gombolyaggal Erdély teóriájától többféleképpen haladhatunk Schillerig. Amint Schiller írja: „Ha ama politikai problémát a tapasztalatban meg akarjuk oldani, az esztétikai problémán keresztül kell vennünk utunkat, mert a szépségen keresztül jutunk el a szabadsághoz.” [Friedrich Schiller: Levelek az ember esztétikai neveléséről. In: Schiller válogatott esztétikai írásai. Ford. 
Szemere Samu. Budapest, 1960. 173. o.] Erdély szépségről vallott gondolatai mellé közvetlenül elhelyezhetjük Schiller igencsak hasonló, utópisztikus sorait, de a gombolyaggal nagyobb utat bejárva érinthetjük Ernst Blochot is, aki előszeretettel idézi Schillert. Erdély ugyanis az 1985-ben, Kalocsán tartott előadásában - mintegy a közönség számára érthetőbbé téve a Marly tézisek üres terét, a helyet a még-meg-nem-valósult számára - a következőket mondja: „Mondjuk énhozzám legközelebb álló - a legjobban megközelíti - ez a bizonyos Ernst Bloch-féle elmélet, ami egy utópikus funkciót tulajdonít a szépségnek és a müvészi munkának. Ami egy még meg nem lévőre [vonatkozik], valami távoli jövőben majd megvalósuló dolognak az üzenete a szépség. Tehát az egy palack, egy fölbonthatatlan palack-postája egy olyan még-meg-nem nyilvánult, vagy talán soha meg nem nyilvánuló transzcendenciának, ami valamifajta reményt és biztatást ébreszt az emberben arra vonatkozólag, hogy más is van, mint ami látszik.” [Erdély Miklós: [A kalocsai előadás]. Videofelvétel alapján. In: MI. 199. o.]

Ha Erdély pedagógiai munkásságából indulunk ki, akkor pedig Szentjóby Paralel-kurzus/Tanpályáján, a fluxuson, John Cage iskoláján, Joseph Beuyson és Robert Fillioun keresztül megérkezhetünk a mindenki mủvész/minden müvészet stabil talajáig, a müvészetnek az embert és a társadalmat alakítani képes erejébe vetett hitéig: Beuys társadalmi plasztikájáig és Fillou Poipoidrom projectjéig. Innen viszont mintegy a törekvések közös ösét keresve ülhetünk le ismét Schiller gondolataihoz, a Levelek az ember esztétikai neveléséröl olvasásához. [Erdélynek, ha nem is igazán mély, de közvetlen tapasztalatai is voltak Beuysról és Filliouról is. Filliou 1976 őszén a Fiatal Müvészek Klubjának volt a vendége Poipoidrom projektjével - itt az 1. sz. Reális Téridejü Poipoidrom épült meg -, ahol feltehetően Erdély is megjelent. 1968 nyarán pedig Nürnbergben, az Altes Künstlerhausban építette fel Altorjay Gáborral a Falakcióját, s ekkor személyesen is találkozott az ugyancsak ott kiállító Beuysszal. Lásd erről Erdély visszaemlékezését: Erdély Miklós: [Nürnberg - Beuys]. In: MI. 37-46. o. Az említettekről pedig lásd legalább a következőket: Joseph Beuys: Not Just a Few Are Called, But Everyone. In: Art in Theory - 1900-1990 - An Anthology of Changing Ideas. Ed. Charles Harrison and Paul Wood. Blackwell Publishers Inc, Oxford UK \& Cambridge USA, 1999. 889-892. o.; Robert Filliou: Teaching and Learning as a Performing Arts. By Robert Filliou and the READER if he wishes, with the participation of John Cage, Benjamin Patterson, George Brecht, Allen Kaprow, Marcel, Vera and Bjoessi and Karl Rot, Dorothy Iannone, 
Erdély Miklós ekkor már a 30-as évei végén jár: az 1966-os Montázs-éhség a második esszéje, melyet sikerült közölnie - a Valóság címü folyóirat ezt is csak úgy jelentette meg, hogy Erdély írásával együtt lehozták annak kritikáját is. ${ }^{214}$ Korábbi alkotói próbálkozásait csak elszigetelten, a nyilvánosságtól elzárva tehette meg. A sorozatos visszautasítások után, nagyjából ekkortól jelenhetett meg mind rendszeresebben különféle alkotásaival. Míg korai munkái is szervesen illeszkednek életművébe, színrelépésének első momentumaival már rögtön egy erős, érett, eredeti és szokatlan szemléletet vitt a magyar mủvészeti életbe. Erdély ekkortól vált fokozatosan a korszak tanító-nevelő mesterévé, központi apafigurájává.

A neoavantgárd fontos tárlatai közül először az IPARTERV-et és a Szürenont egyesítő „R”-kiállításon vett részt 1970-ben. Ahogy már írtam, a két IPARTERV-tárlaton kiállító művészeket az egykorú kritika a kiállítás tere alapján - az IPARTERV Vállalat Deák Ferenc utca 10. szám alatti irodaházának nagyterme - egyszerűen metonimikus névátvitellel IPARTERV-generációnak nevezte el. Ehhez nekünk, ha pontosak szeretnénk lenni, annyit kell még hozzátennünk, hogy Erdély egy kvázi generációugrással került be a nála többnyire fiatalabbak csoportjába. ${ }^{215}$ Ekkor és közöttük még egyetlen alkotó sem volt, akit Erdély tanítványának

Diter Rot, Joseph Beuys. König Verlag, Cologne and New York, 1970.; Hannah Higgins: Fluxus experience. University of California Press, Berkeley, Los Angeles, London, 2002.]

${ }^{214}$ Lásd még: Peternák Miklós: Interdiszciplinaritás. Új médiumok az elmúlt három évtized magyar művészetében - vagy kire hatott Erdély Miklós és kire nem? In: A második nyilvánosság - XX. századi magyar müvészet. Összeállította Hans Knoll. Enciklopédia Kiadó, Budapest, 2002. 251. o.]

215 A generációk egymásra rétegződéséről lásd még: Körner Éva: Magyar avantgárd - izmusok nélkül. I. rész. In: Új Müvészet. 1994/4-5. sz. 7. o. 
tarthatnánk, egyedül a ’69-es IPARTERV-kiállításon már szereplő Szentjóby Tamást említhetjük - őt viszont helyesebb, ha nem tanítványaként, hanem közeli munkatársaként látjuk. ${ }^{216} 1967$ áprilisában 3tia testis - Kezdet címen Szentjóby Tamás, Altorjay Gábor, valamint Altorjai Sándor és Erdély Miklós a Magyar Írók Szövetsége székházában mutatták be akcióikat; szintúgy '67-ben született az ORGIA címü tervezet, melyet a Mủegyetem hallgatóival kivitelezett volna Erdély, Szentjóby és Altorjay; '67 novemberében az Egyetemi Színpadon mutatta be Szentjóby Kvarc című akciószínházát, majd ugyanitt '68 januárjában akciókoncertjét; 1968 februárjában Rejtett paraméterek címen az Utasellátó Vállalat Arany János utcai klubjában Poór István szervezésében Erdély előadást tartott a happening tárgyában, majd Szentjóby bemutatott egy happeninget; 1968. májusi az UFO (Találka), mely Erdély és Szentjóby ötlete, Szentjóby hosszas levelezése és előkészítése nyomán a szentendrei dunaparton valósult meg Roger Bentichouval, Dárday Istvánnal, Dúl Antallal, Szalai Györgyivel, Urbán Miklóssal és Ladik Katalinnal; Erdély és Szentjóby egymás után és egymással mutatták be önálló akcióikat ’68 novemberében az IPARTERV Vállalat irodaházában, a közös ötletük alapján, ám végül

\footnotetext{
216 Körner Éva Erdély eddig húzódó nyilvános jelentkezésének okát azzal indokolja, hogy ezidáig egyszerűen a „korszellem” nem tudta őt vállalni. [Lásd: Uo.] Perneczky Géza a II. IPARTERV-kiállítást pedig egyenesen azért tartja érdekesnek, mert itt már Erdély növekvőfélben lévő befolyását látta. [Perneczky Géza: Produktivitásra ítélve? Az Iparterv-csoport és ami utána következett Magyarországon. 1. rész. In: Balkon. 1996/1-2. sz. 11. o., 17. o.] Mindenesetre, Erdély úgy emlékszik: „[...] [E]leinte még az avantgardból is kilógtam; ez az Iparterv kiállításokról való rendszeres kihagyásom. Amikor megjelent, a II.-nál, a Dokumentum-katalógus, akkor már nem bírták az ellenállást, és Konkoly a katalógusba kért tőlem anyagot.” [Peternák Miklós: Beszélgetés Erdély Miklóssal 1983 tavaszán. In: Árgus. 1991. szeptember-október, II. évf. 5. sz. 78. o.]
} 
Szentjóby által megszervezett Do You See What I See? címü esten; 1969 februárjában az Építők Pesterzsébeti Művelődési Otthonában Erdély Miklós, Szentjóby Tamás, Konkoly Gyula és Urbán Miklós közösen tartottak fluxkoncertet; 1969 júliusában pedig Erdély és Szentjóby különkülön, ki-ki a saját otthonában, de egyszerre hajtották végre akcióikat Paralel akció a holdra szálláskor címen.

Mielőtt Erdély Miklósnál maradnánk, térjünk is kicsit vissza Szentjóbyhoz. Legalább felsorolás szintjén, de azért címszavaknál kicsit bővebben vegyük sorra, Szentjóby Tamásnak mely munkái születtek még ekkoriban, azaz a neoavantgárd kezdeti időszakában, 1965 és 1970 között.

Ebben az időszakban született többek között a Hülö víz, az Új mértékegység, a Csehszlovák rádió 1968, a Háromszemélyes hordozható lövészárok és a Kiemelés/5. Ezek mind olyan munkái Szentjóbynak, amelyek arról tanúskodnak, hogy a '60-as évek második felének honi és külföldi történései közvetlen, kemény, a világ aktualitása felé nyitó társadalmi tudatosságot hoztak el számára. ${ }^{217}$ Szentjóby ezen munkái - akár

${ }^{217}$ Esetében ezek az évek egy lebegő, efemer művészetet váltottak fel: alkotói munkásságát misztikus, metafizikus költőként kezdte. A versírással 1966-ban hagyott fel, miután megírta „utolsó”, Pilinszkynek ajánlott versét, ahogy több helyütt magyarázza, számára áthidalhatatlan nyelvi problémák miatt. A nyelvet ugyanakkor közel sem hagyta el - munkáinak meghatározó közege a nyelvi, fogalmi gondolkodás. Mondhatjuk úgy is, munkái egyfajta fogalmi sürüsödés tapinthatóvá tömörülései. [Lásd: Hegyi Dóra - László Zsuzsa: Interjú St.Auby Tamással. In: Az ebéd (In memoriam Batu kán). HAPPENING Budapest H 1966. The Lunch (In Memoriam Batu Khan). Szerk. László Zsuzsa, St. Turba Tamás. Ford. Polonyi Csaba. Tranzit Hungary Közhasznú Egyesület, Budapest, 2011. 1620. o. Első megjelenés: Dóra Hegyi and Zsuzsa László in conversation with Tamás St.Auby. In: Gallery Nova Newspapers. 2009. 19/20. sz. 37-41. o.; Békés Izabella: St. Auby Tamás, a nem müvészet müvésze. In: Bárka. 2010. XVIII. évf. 4. sz. 78-84. o.] De megjegyezhetjük, Szentjóby már 1966 elött is foglalkozott 
még az alkotói intenciójuk ellenében is - konkrét politikai, gazdasági eseményekre, recens hírekre reagálnak. Kikerülhetetlen intenzitásuk tényszerű gyökerekből táplálkozik: nyugat felől az 1968 májusában felszínre törő párizsi diáknyugtalanságból, itthon az új gazdasági mechanizmusból, észak-kelet felől pedig abból, hogy a Varsói szerződés országainak hadtestei 1968. augusztus 21-én bevonultak a testvéri Csehszlovákiába.

Szentjóby a Hülö viz és az Új mértékegység objektjeit 1965-ben, Petri-Galla Pál lakásán tervezte bemutatni, majd ezeket végül a mindössze három napig látogatható 1969-es, II. IPARTERV-tárlaton állította ki. ${ }^{218} \mathrm{~A}$

„aktuál-politikai verseny-versírással” a Buta Költők Körében. Altorjay Gáborral, László Andrással és Tárkányi Zoltánnal nem szavakat adtak egymásnak, ahogy Erdély Miklós, Altorjai Sándor és Szabó Ákos, hanem „népszerü” témákat, majd pontozással döntötték el, kié lett a legjobb munka. Verseltek „a népi kollégisták 10 éves találkozója” tárgyában, de írtak a „részeg úrvezető a falu utcáján” és az „ürhajós” témájában is. [Lásd még: Dékei Krisztina: A magyar irodalom és képzőművészet néhány kapcsolódási pontja (1965-1974). In: Kép - írás müvészet. Tanulmányok a 19-20. századi magyar képzömüvészet és irodalom kapcsolatáról. Szerk. Kékesi Zoltán és Peternák Miklós. Ráció Kiadó, Budapest, 2006. 48-49. o.]

218 Annak a történeti ívnek a jókedvü anekdotázástól sem mentes leírását, miszerint Petri-Galla Pál Vécsei utcai, súlyos bársonyfüggönyökkel elsötétíthető lakásának tekintélyét - ahol „Bachot hallgatni [...] a politikai ellenállás egyik formája volt” - elöször Erdély Miklós Virágárok utcai háza tudta csak kikezdeni, lásd: Perneczky Géza: Produktivitásra ítélve? Az Iparterv-csoport és ami utána következett Magyarországon. 1. rész. In: Balkon. 1996/1-2. sz. 9. o. [A Virágárokról lásd még: Ágh István: Virágárok. In: Magyar Nemzet. 1989. május 6. LII. évf. 104. sz. 11. o. Újraközölve: Uő: Virágárok. Kortárs Kiadó, Budapest, 1996. 76-83. o.; Uő: Kidöntött fáink suttogása. Nap Kiadó, Budapest, 2008. 310315. o.; Jolsvai András: Ó, azok a hatvanas évek! Rejtett közösségek hálózata. (Beszélgetés Deák Lászlóval). In: Magyar Nemzet. 1991. március 14. LIV. évf. 62. sz. 12. o.; Erdély Dániel: A múlt mozaikjai. In: Kultúra és Közösség. 1990. 
Hülő víz egy átlátszó patikai üveg meleg vízzel töltve. A Hülő víz egy olyan objekt, amely csak bizonyos feltételek mellett müködik: Szentjóby a kiállításon naponta többször melegre cserélte az üveg tartalmát, a vizet, hogy az újra lehűlhessen, hogy a mütárgy újra „legyen”. ${ }^{219}$ És mütárgyként létezésének szükséges feltétele nem is csupán ennyi: ahogy más konceptuális tárgyaknál, itt is kell egy cím és az élet kontextusa ahhoz, hogy az egyszerü, önmagában álló tárgy önmagán túlra is mutathasson. A Hülő víz a maga közvetlen tisztaságában, fizikális folyamatának közvetlenül megtapasztalható, tényszerü legördülésében akár még a realitás alá hajtott élet legtágabb, megfogalmazhatatlan metafizikai tartalmait is képes egy csapásra láthatóvá tenni - miközben a tárgyat egy másik irányból, mindössze a hétköznapok bornírtságának perspektívájából,

szeptember-október-november-december, XVII. évf. 4. sz. 147. o.; Mújdricza Péter: Imaginárius terek. In: Új Magyar Építömüvészet. 1999/4. sz. 41. o., 54-56. o. Újraközölve: In: Magyar Mühely. 1999. XXXVII. évf. 110-111. sz. 165-171. o.]

219 Lásd Körner Éva és Kürti Emese leírását. Körner Éva: Az abszurd mint koncepció. Jelenetek a magyar koncept art történetéből. II. rész. In: Balkon. 1993/2. sz. 11. o.; Kürti Emese: "Dezorientáljuk a csapatokat" St.Auby Tamás kiállítása Karlsruhéban $1 . \quad$ Interneten: http://exindex.hu/index.php?l=hu\&page=3\&id=773; 2012. 03. 10. Lásd még: Rózsa T. Endre: Az utak összeérnek? In: Kritika. 1971/6. sz. 56. o. Újraközölve: In: Ars Hungarica. 1991/1. sz. 128. o.; Láncz Sándor: Van-e modern realista szintézis a mai magyar képzőművészetben? Gondolatok Szabolcsi Miklós „Jel és kiáltás” címü könyve nyomán. In: Müvészet. 1971. december, XII. évf. 12. sz. 8. o.; Beke László: KENTAUR. In: Magyar Mühely. 1978. június, XVI. évf. 54-55. sz. 69. o. Újraközölve: In: Mozgó Film 2. A BBS Mühelykiadványa. Szerk. Forgács Péter. A „K” rovatot szerkesztette: Beke László. Balázs Béla Stúdió, Budapest, 1986. 205. o. 
aktualitásában szemlélve akár az „olvadás” pártszlogen provokatív, pejoratív megismétlésének is vélhetjük. ${ }^{220}$

Az Új mértékegység ugyancsak konceptuális objekt: egy 60 cm-nél kisebb üreges ólomcső vízszintesen elhelyezve. Arról, hogy ezt már az egyidejü, majd a későbbi müértelmezők is direkt politikai objektként kezelték - és arról, hogy a mü kiállításával miként válik le az alkotott az alkotójáról - Szentjóby Tamás szavai tanúskodnak: „És akkor rémültem meg, hogy [...] én most egy gumibotot vagy egy ólombotot állítottam ki és ráadásul mint egy új mértékegységet? A rendőrségi gumibot mint új mértékadó? De aztán gondoltam, hogy ez nem lesz annyira nyilvánvaló a közönség számára, de amikor a kiállításon mindenki ezzel jött, hogy na mi van, izé? Gumibot? Akkor nagyon fölidegesített ez, és én ezt sajnálom, tudniillik engem, legalábbis akkor, sokkal inkább foglalkoztatott, nem foglalkoztatott, sokkal inkább érintett az, hogy a mértékegység maga új, mint az, hogy utalás az ólombotra.”221 Az Új mértékegység ezért számunkra legalább úgy szólhat a kor tárlatlátogató közönségének értelmezői involváltságáról, mint Szentjóby Tamás életművének erről a szakaszáról. A közönség, úgy tünik, az Új mértékegység Rorschach-tesztjét nem tudta

\footnotetext{
${ }^{220}$ Az „olvadás” mint a reformtörekvések szinonimája eredendően a hruscsovi „desztalinizáló” időkhöz köthető. Ennek az enyhülésnek a magyarországi megfelelöje a Rákosi Mátyást váltó Nagy Imre miniszterelnökségének az ideje. Az enyhülést újabb szigor követte: Gerő Ernő, az 1956-os forradalom és a forradalom utáni megtorlások. Az „olvadás” szlogenjének újramelegítése az 1960as évekre tehető: az 1963-as amnesztiákhoz és a már ekkortól tervezett, majd 1968. január 1-ével bevezetett új gazdasági mechanizmushoz társítva.

221 Beszélgetés Szentjóby Tamással. In: Jelenlét. Szógettó. Válogatás az új magyar avantgarde dokumentumaiból. Az ELTE-BTK irodalmi-múvészeti folyóirata, 1989/1-2., 14-15. sz. 261. o. (A beszélgetést Beke László vette hangszalagra 1971. március 11-én.)
} 
politikailag semleges tekintettel látni. Nem egy közönséges, talán építkezésről kimaradt fémcsövet láttak, de nem is a kategóriarendszerek felülvizsgálatának javaslatát, hanem - a durvának azért nem feltétlenül, szelídnek viszont semmiképp sem mondható - fémdurung látványától indíttatva speciális gumibotot, avagy akár „ólomfütyköst”. 222

${ }^{222}$ Az ólomfütykösként látás speciel Perneczky Géza tekintetének szituáltságáról árulkodik. [Perneczky Géza: Produktivitásra ítélve? Az Iparterv-csoport és ami utána következett Magyarországon. 1. rész. In: Balkon. 1996/1-2. sz. 8. o.]

Szentjóby Tamás a fentebb idézett, 1971-ben, Beke László által készített interjúban mindkét említett objektjéröl beszél. Ebben a Hülő víz allegóriájának ugyancsak az aktuálpolitikainál tágabb interpretációját adja: „A puszta létezés állandó presszió alatt van, a valóság pressziója alatt. [...] A Hülö víz persze remélem - nemcsak a tragikumról való információjával hat, hanem a puszta automatikus és kényszerű változással is, mintegy a szemlélet olyan irányba fordítása, amely irány lényegtelennek látszik a hétköznapi élet súlyosabb presszióiban [...].” [Uo. 260. o.]

A tárgyak leírásakor természetesen igyekszem figyelembe venni az azokat létrehozó mủvész tolmácsolását is. Azonban az irányzatok, hazai és nemzetközi törekvések mentén történő elhelyezési kísérleteink során minduntalan belebotlunk abba, hogy az irányzatok elnevezését és tartalmát az egykorú mủvészek korántsem használják konzisztensen. Szentjóby ezeket a munkáit az imént említett interjúban még „pop-objektek”-ként említi - ezért tűnhet úgy is, hogy számára ekkor maga a pop art elnevezés volt popos. A pop art mint meghatározás a formai jegyektől függetlenül csupán a tartalomra vonatkozott, arra is csak annyiban, hogy annak friss, a hétköznapok felé is megnyíló aktualitását jelölte meg mint egy mütárgy differencia specificáját, akár a tisztán metafizika felé törekvő korábbi alkotásai ellenpontjaként. Hiszen csak meglehetősen erőteljes mozdulatokkal lehetne idecitálni a pop art első generációját, mikor is a felhasznált tárgyak, anyagok és a létrejött (mű)alkotások közötti távolság eltűnni látszik egy ironikus gesztusban, mígnem a tárgy önmagára vonatkozó ikonná duzzad. De a pop art '62 körül jelentkező második generációját is csak bajosan köthetnénk ide, mikor már a tömegkultúra hirdetésein, reklámjain átpréselt információk válnak témává. Ehhez pedig hozzátehetjük az Összefoglaló jelentés és intézkedési terv egy részletét, mely egy hálózati jelentésből idéz, miszerint 
Szentjóby Tamás két 1969-es munkáját, a Csehszlovák rádió 1968at és a Háromszemélyes hordozható lövészárkot szemlélve már nem szükséges megannyi lehetséges irányba polarizálni tekintetünket. A Csehszlovák rádió 1968 - egy kénlappal körberagasztott, hosszanti élére állított tégla - nagyon is egyértelműen a ' 68 -as prágai forradalomra utal. A Háromszemélyes hordozható lövészárokkal pedig - két rúd, közötte nagyméretű csüngő forma, gézből, nádból, gipszből és kénből összeállítva - Szentjóby már a kemény provokáción is túllendülve egyértelmüen támadni kezd. ${ }^{223}$ Az ugyancsak 1969-ben született Kiemelés/5 címü ötlet-

1968 márciusának egyik estéjén Poór István, Erdély Miklós és Szentjóby Tamás a Kárpátiában sörözve bemutatót terveztek, és „[m]egállapodtak abban, hogy a bemutató szervezője és a müsor vezetője Poór István lesz. Erdély Miklós fogja ideológiailag kellőképpen megalapozni, szükség esetén ujabb [sic!] külföldi irodalommal ellátni a müsor szerkesztőket [sic!]. [...] A beszélgetés során Poór István megemlítette azt is, hogy az utóbbi időben a rendőrség nagyon felfigyelt a happening szóra, illetve bemutatókra. Allergiások a rendőrök a happeningre, azonnal paprikások lesznek e szó hallgatára [sic!] és mindent elkövetnek a bemutatók megakadályozására. Ezért a jövőben a bemutatók meghirdetésénél kerülni kell a happening szó használatát, inkább op-part-ot, pop-art-ot, vagy más szót használnak.” [Összefoglaló jelentés és intézkedési terv. In: V-156455 számú dosszié. ("Schwitters"). 106. lap] Szó mi szó, a hivatásos, ám titkos müértelmezőknek sem lehetett egyszerü dolga az eladdig Magyarországon nem létező irányzatokkal. Mindenesetre Szentjóby munkáinak az interpretációját a hatóság - pop art ide vagy oda - végrehajtotta: eszerint a veszélyes zavar gerjesztésének forrása egy zárlatos elme hibás működése. „A happening főbb szervezőit figyelmeztetni kell annak érdekében, hogy a jövőben tervezett bemutatóktól álljanak el. Különös tekintettel Szentjóby Tamásra, aki a legaktívabb tevékenységet fejti ki ezen a téren. Felhívni Szentjóby figyelmét arra, hogy ha a jövőben sem hajlandó a happening bemutatók szervezésétől elállni, akkor javaslatot teszünk zárt intézetben való kezelésére.” [Uo. 110. lap]

${ }^{223}$ A Csehszlovák rádió 1968-at meghatározhatjuk úgy, hogy az egy multiplika, azaz könnyen, bárki által előállítható, sokszorosítható műtárgy - ahogy, tegyük 
hozzá gyorsan, a Hülő viz, az Új mértékegység és a Háromszemélyes hordozható lövészárok is az. Csakhogy Szentjóbynak ez a munkája úgy is multiplika, hogy már az eredeti, 1969-ben kiállított tárgy is másolat, kicsi módosítással. 1968 nyarán Prágában betiltották a rádióhallgatást. Szentjóby munkája azt a városi leleményességet követi, hogy a tiltásra reagálva ekkor többen újságpapírba csomagolt téglát kezdtek hallgatni. Szentjóby pályájának markáns, folyamatosan jelen lévő törekvése a művészet és az élet szoros, szinte megkülönböztethetetlen viszonyának feltérképezése. (Lásd például Szentjóby Ki a müvész? címü 1973-ban készült fotósorozatát: a Festő címủ egy szobafestőt ábrázol munka közben, az Író egy nyomdász képe, a Land artist útépítő munkásoké, a Mail artist pedig egy posta épületéből leveleszsákkal kilépő postásé.) Ebbe a programba illeszkedik szervesen a Csehszlovák rádió 1968 is: eszerint a tégla nemcsak a '68-as prágai tavasznak és a forradalommal való szolidaritásnak a mementója, hanem a mủvészet társadalmi fordulatának, a nagyvárosi multiplikának is a sokszorosítható emlékmüve. [Lásd ehhez: http://multiplika2000.wordpress.com/asokszorozvanyokrol-multiplikakrol-roviden; 2012. 03. 10., valamint Maja Fowkes és Reuben Fowkes interjúját Szentjóby Tamással: http://www.translocal.org/revolutioniloveyou/stauby.html; 2012. 03.10. Szentjóby munkáiban a meglehetősen sokféle anyag közül ebben az időben talán a ként használja legkövetkezetesebben. Anya(g)nyelvében a kénnek nem is egyszerủen a fizikális tulajdonságai dominálnak - nem egyszerủen a zöldessárga színe, az átható szaga vagy a faktúrája -, de nem is csupán a közkeletủ konnotációi - Nap, pokol, arany -, hanem akár a kémiai tulajdonságai - képes reakcióba lépni az oxigénnel és a fémek többségével, könnyen gyújtható, égésekor méregező gáz keletkezik, a puskapor egyik összetevője -, de leginkább ezeken is túlmutatva, a kén alkímiai jelentősége. A kén az alpvető, az eredendő, az ősegy, az ősanyag (Prima matéria, 1969), és az abból létrejövő, de akár létre is hozható, átalakítható világ felé vezet. A kén használatáról Szentjóby munkáiban lásd még: Beke László: KENTAUR. In: Magyar Mühely. 1978. június, XVI. évf. 54-55. sz. 68-69. o. Újraközölve: In: Mozgó Film 2. A BBS Mühelykiadványa. Szerk. Forgács Péter. A „K” rovatot szerkesztette: Beke László. Balázs Béla Stúdió, Budapest, 1986. 203-205. o.; Peternák Miklós: A konceptuális müvészet hatása Magyarországon. 1983-85. Interneten: http://www.c3.hu/collection/koncept/help.html; 2012. 11. 23.; Peternák Miklós: concept.hu| koncept.hu. A konceptuális müvészet hatása Magyarországon. The 
Influence of Conceptual Art in Hungary. Paksi Képtár - C3 Alapítvány, 2014. 44. o.]

A Háromszemélyes hordozható lövészárokhoz pedig azt tehetjük még hozzá, ha finomabbak szeretnénk lenni, hogy ez egyúttal akár a konfrontálódásban kapott és adott sérülések elkerülhetetlenségének is az installációja: a 2 rúd, közötte a méretes géz-nád-kén-gipsszel úgy volt a térbe installálva, hogy a rudak között U-alakban, mereven álló konstrukció első és talán harmadik látásra is lövészárok helyett inkább háromszemélyes hordágyhoz, avagy háromszemélyes gipszágyhoz volt hasonlatos.

És ha már a téglánál tartunk, még ha át is csapunk a '70-es évek elejére, azért említsünk meg egy Beke László által felerősített tendenciát is. Csáji Attila 1971 és 1973 között készíti Utcakö-sorozatát, melynek egyik darabjaként ’71-ben utcakövet csomagol, de nem elrejtve azt, hanem a Magyar Vendéglátóipari Vállalat átlátszó, mủanyag süteményes dobozába helyezve (A proletariátus fegyvere az utcakö). Ugyanebben az évben Maurer Dóra elkészíti Mit lehet csinálni egy utcakővel? címü fotósorozatát, Gáyor Tibor végrehajtja Utcaköakcióit, Lakner László pedig megfesti hiperrealista utcaköveit (A forradalom emlékmüve). Beke László a következő év elején meghirdeti Utcakövek és sírkövek címü kanalizáló akcióját, Pauer Gyula ekkoriban (1971-72) készíti el pszeudoutcakövét, melyet a párjával együtt állít ki (Utcakő és pszeudo mása), Gulyás Gyula pedig nagyobb, egészen a pályája végéig átívelő sorozatba kezd: egy utcakövet felirattal lát el és hitelesít (Magyar gyártmányú utcakö), egy másikat piros-fehér-zöldre fest, majd március 15-ére postán elküld Tót Endrének (Magyar utcakő), egy harmadikat pedig a „MADE IN HUNGARY” felirat mellett két masszív fémfüllel lát el (Hordozható utcakö); egy évvel később gázálarctáskából átalakítva, bőrszíjakkal, fülekkel ellátott, praktikus, strapabíró táskát készít utcakőhöz (1919.), betonvassal tart egyben két, villamossínnel elválasztott utcakövet (Félbevágott), de egy bazalt- és egy gránitkockát is összefogat (BudaPest). Pinczehelyi Sándor, aki már 1972-ben ötágú csillagot rak ki utcakövekből, 1974-ben utcakövekre festi (szitázza) az ismert szlogent, hogy „A proletariátus fegyvere” (Az utcakő a proletariátus fegyvere), majd '76-ban, mintegy tevékenysége súlyát is megtapasztalva, öt bazaltkocát felemelve fotózza magát (Öt utcakő). Erdély Miklós pedig Beke László felhívására reagálva 1972-ben a János Kórház előtti macskaköves útra írja fel múlékony, az első esővel eltünő bibliai idézetét: „Ha az emberek elhallgatnak, a kövek fognak beszélni.” [Lukács 19.40.] 
Beke László 1972 júliusában Balatonbogláron, a Direkt hét keretében megtartott Utcakövek és sírkövek címü diavetítési projektjére Erdély eredetileg egy Kondor Béla ablakából kizuhanó követ akart lefilmezni és fényképezni Sarkadi Imre emlékére, aki Kondor hatodik emeleti müteremlakásából zuhant az alatta lévő kockakövekre. Kondort és Erdélyt 1953-54-től majd húsz éven át szoros barátság kötötte össze: a különbségeken átívelő közös attitűd, a gyöngéiből egymást kipiszkálni próbáló szellemi partnerség. Egy időre, nagyjából 1957-től 1963-ig hármasban, Pilinszky Jánossal kiegészülve járták az éjszakákat. Az anekdota szerint Erdély Pilinszkyvel hajnalban, néhány perccel azelőtt, hogy Sarkadi a párkányra lépett volna, épp Kondor lakása alatt voltak a Bécsi utcában, látták is a fényeket, gondolkodtak, felmenjenek-e vagy mégse, vagy mégis, ám végül továbbálltak. A Sarkadi emlékére tervezett filmre és fotóra végül Kondor nemet mondott. A történet azzal bonyolódott - és vált meglehetősen ízléstelenné , hogy Kondor távozása után a Kritika egy nekrológ mellett közölt egy „dokumentumot” is. Egy titokban felvett beszélgetés leiratát - állítólag Varga Gábor felvételét -, melyen Kondor jóízűen ironizálva éppen Erdély tervéről mondja el, hogy nem kellene megvalósítani. Rózsa Gyula a nekrológban úgy utal erre: „S igen erősnek kell lennie annak, aki kitaszítottsága ellenére megnézi, kikkel együtt kitaszított, s akkor sem vállalja a közösséget pillanatemberekkel, ha ezekkel a pillanatemberekkel egy nevezőre hozzák. Alább dokumentumot közlünk; nyers, kamaszosan szabadszájú, széplelkeknek ismét fájdalmat okozó Kondor-dokumentumot arról, hogy Kondor nem alkudott és nem kötött üzletet; akkor sem, ha bizonyos nézőpontokból egy gyékényen látták felettébb kétes üzletfelekkel [...].” A „dokumentumot” természetesen a konceptuális művészet és általában az egész avantgárd ellen megpróbálták kijátszani. A nekrológ-ügy egészen a '80-as évekig érzékeny témának számított. [Erdély az egyik interjúban '53-ra, a másikban '54-re teszi megismerkedését Kondorral. A terve kapcsán videózásra emlékszik, Beke László pedig fotózást említ, Kondor azonban mindkettőt egyszerre: szerinte Erdély fentről filmezni tervezte a zuhanó követ, lent, a becsapódás előtt pedig fotózni. [R. [Rózsa Gyula]: Kondor Béla 19311972. In: Kritika. 1973/2. sz. 14. o.; Egy Kondor-dokumentum. In: Kritika. 1973/2. sz. 14. o.; Ember Mária: Magnósok járnak közöttünk? In: Kritika. 1973/4. sz. 2. o.; Rózsa Gyula: Válasz. In: Kritika. 1973/4. sz. 2. o.; Erdély Miklós Kondor Béláról. Részlet egy 1981 körül készült magnófelvételből. In: Beszélő. 1999. január, III. folyam, IV. évf. 1. sz. 104-115. o. A hangfelvétellel együtt lásd/hallgasd: http://artpool.hu/Erdely/Kondor.html; 2013. 07. 28.; „Kicsit úgy 
munkája pedig a szabad mozgást, a politikai frontvonal eliminálását javasolja. A mủ írólapon tollal készült rajz, fölötte a következő, géppel írt felhívással: „Tekintettel arra, hogy az emberi jogok egyetemes deklarációja 13. cikkelyének nem tudok érvényt szerezni, kérlek, utazz el helyettem a magyar-jugoszláv-osztrák, illetve a magyar-cseh-osztrák határok találkozási pontjaihoz, és helyezz el ott egy lábakon álló vagy földbeszúrt idézőjelet [...]." A mű az idézőjelek pontos méretét $(30$ x $13 \mathrm{~cm})$ és anyagát (fa vagy fém) is instruálja, ahogy azt is, hogy a nagyszabású térinstalláció-tervezet melyik oldalról mutassa magát idézőjelnek: a jeleket úgy kell elhelyezni/elképzelni, hogy a jugoszláv határon a föld szintjén, a csehszlovák határon minimum fejmagasságban álljanak. ${ }^{224}$

nézte ezeket a dolgokat, mint a tyúk a piros kukoricát...” Erdély Miklós Kondor Béla és az avantgárd kapcsolatáról - archív interjúszöveg 1983-ból. A beszélgetést készítette: Rényi András. A csak legépelt példányban fennmaradt szöveget gondozta, jegyzetekkel ellátta: Szőke Annamária. In: Müút. 2013/037. sz. 50-58. o.; György Péter: A hely szelleme. [Recenzió a Törvénytelen avantgárd. Galántai György balatonboglári kápolnamüterme 1970-1973 címü kötetről.] In: BUKSZ. 2004 tél, 16. évf. 4. sz. 328-335. o. Interneten: http://www.artpool.hu/boglar/sajto/buksz gyorgyp.html; 2013. 07. 28.; Erdély Miklós: KB. In: MI. 14-22. o.; Halász András: Közvetítés pohárban. In: Magyar Mühely. 1983. július, XXI. évf. 67. sz. 42. o.; Beke László: Erdély Miklós munkássága. Krono-logikai vázlat képekkel 1985-ig. In: Erdély Miklós. Kiállítási katalógus, Óbuda Galéria, Zichy Kastély, 1986. április 11. - május 5. 10-11. o. A végzetes estéről lásd: Ágh István: Kondor-memoár. In: Magyar Nemzet. 1989. február 25. LII. évf. 48. sz. 11. o. Újraközölve: Uő: Virágárok. Kortárs Kiadó, Budapest, 1996. 58-66. o.; Uő: Kidöntött fáink suttogása. Nap Kiadó, Budapest, 2008. 304-310. o.]

224 A hivatkozott 13. cikkely két pontból áll: „1. Az államon belül minden személynek joga van szabadon mozogni és lakóhelyét szabadon megválasztani. 2. Minden személynek joga van minden országot, ideértve saját hazáját is, elhagyni, valamint saját hazájába visszatérni." Amihez hozzáfüzhetjük, hogy az idézőjelek, helyzetükből adódóan mintegy diódaként viselkedve talán inkább teszik 
A Kiemelés/5-tel már a ’70-es évek elejéhez közelítünk. Egyelőre maradjunk a korábbi időszaknál, és térjünk vissza Erdély Miklóshoz.

Erdély első nyilvános szereplésének az Örizetlen pénz az utcán című akciót tarthatjuk. 1956. november elején Budapest hat forgalmas pontján többedmagával pénzgyüjtő ládákat helyezett el, fölébük plakátot kifüggesztve, melyekre egy-egy 100 Ft-ost, az akkori legnagyobb címletủ bankjegyet ragasztott, majd örizetlenül hagyták az estére pénzzel csordultig megtelő ládákat. A plakátokon a következő felirat szerepelt: „Forradalmunk tisztasága megengedi, hogy így gyüjtsünk mártírjaink családjának.” Peternák Miklóssal beszélgetve erre a következőképpen emlékszik:

P. M. [Peternák Miklós]: Térjünk vissza oda, hogy a koncept hogy alakult ki? E. M. [Erdély Miklós]: Hogy alakult ki ez az egész? Én ennek egy áldozata vagyok. Fogalmam se volt a konceptröl, illetve volt egy belső mozgása a müvészeti törekvéseknek. [...] Bennem először, hogy tudniillik a müvészet nem csak arra való, amire használják - tehát díszítő-, mügyüjtemény- és müalkotás-funkciókra való - az 1956-ban jutott eszembe. [...] P. M.: És mi volt az, amit te csináltál? E. M.: Az a bizonyos »Örizetlen pénz az utcán«. Olyan plakátot csináltam hatot, amibe belefüztem összesen hatszáz forintot, mindegyikbe kihúzhatóan a százast. Mikor feljöttek hozzám a müvészek, Gáyor és mások, hogy csináljunk új folyóiratot, stb... akkor már éreztem, hogy annyira mozgásban vannak a dolgok, mert hallottam a rádióban azt, hogy valaki belelőtt egy kirakatba és egy cipő megsérült, a sarka alá rakott egy tíz forintost, s azóta ott van. Ez a lényeges. Ez az új. Akkor egy társaságot verbuváltunk, és

lehetővé/elképzelhetővé a saját haza elhagyását, semmint az oda való visszatérést. [Az Emberi Jogok Egyetemes Nyilatkozatát lásd az ENSZ hivatalos honlapján: http://www.ohchr.org/EN/UDHR/Pages/Language.aspx?LangID=hng; 2013. 07. 28. A munkához lásd még: Boros Géza: A szabadság kapujában. Kommentár egy Szentjóby-mühöz. In: Balkon. 1999/1-2. sz. 31-32. o.] 
megoldottuk, hogy Budapest hat pontján dobálják be a pénzt az őrizetlen ládába, s ettől kezdve az volt a feladatom, hogy járkáltam az Írószövetség autójával és a láda mellé álló nemzetőröket elzavartam, mert képtelenek voltak felfogni, hogy ezt most nem kell őrizni. Majdnem belém lőttek egyszer, mikor azt mondtam, fiúk, takarodjatok a láda mellől... [...]. ${ }^{225}$

Az esemény nagy nyilvánosságot kapott a sajtóban, rövidebbhosszab írások, fotók jelentek meg róla, ám Erdély szerepe - a saját visszaemlékezésén túl - nem tisztázható pontosan. ${ }^{226}$ De talán ennél

225 Peternák Miklós: Beszélgetés Erdély Miklóssal 1983 tavaszán. In: Árgus. 1991. szeptember-október, II. évf. 5. sz. 86. o.

${ }^{226}$ A Magyar Nemzet az eseményről Örizetlen százasok a pesti utcán címen számol be: „A sok csoda, amelynek szabadságharcunk napjaiban szüntelenül szemtanúi voltunk, óráról órára új csodákkal gyarapszik. A Tanács körút és a Kossuth Lajos utca sarkán, a nagy gyógyszertár előtt találkoztunk ezzel a legújabb csodával. A gyógyszertár Kossuth Lajos utcai kirakatában a következő tábla függ: »Forradalmunk tisztasága megengedi, hogy így gyüjtsünk mártírjaink családjainak. A Magyar Írók Szövetsége.« A tábla aljában ezt olvassuk: »A ládát a Magyar Írók Szövetségének gépkocsija 5 és 6 óra között szállítja el.« A nyomtatott táblán egy százforintost ragasztottak át ragasztószalaggal. Alatta a kirakat mélyedésében, esőtől védve, nagy zöld vasláda, 20, 10, 100 forintosokkal és fémpénzzel. Másodpercenként újabb és újabb bankók, pénzdarabok repülnek a ládába. Az arrajárók közül alig akad valaki, aki a maga kis adományát ne helyezné el benne. De olyan sem akad, aki bünös kézzel hozzányúlna a sok ezer forintra tehető, összegyült pénzhez. Ebben és a többi ládában több mint 100000 forint gyűlt össze az első napon. Ilyen jószívü és becsületes a forradalmi Budapest." [Örizetlen százasok a pesti utcán. In: Magyar Nemzet. 1956. november 3. XIX. évf. 257. sz. 3. o.] A Valóság hasábjain: „Ha pesti ember napjainkban csoportosulást lát az utcán, tudja, vagy újságot árulnak, vagy élelmet osztanak, vagy esetleg a legújabb vidéki híreket ismertetik a szemtanúk. Ám az, aki az Astoria-szálló sarkán lévő nagy tömeget látva erre gondol - nagyot csalódik. Egy nyitott láda az, mely oda csalja az embereket és arra indítja, hogy pénztárcájukba nyúlva adakozzanak. A ládát az Írószövetség helyezte el, azzal a felírással: Forradalmunk tisztasága lehetővé tette, hogy így gyűjtsünk. A gyűjtést a 
szabadságharcban vértanúhalált haltak családjának megsegítésére indították. S gyülik a forint, a 10 forint, a 100 forint, ki mennyit tud, annyit tesz a nyitott ládába. Tegnap sötétedésig kétszer kellett kiüríteni a ládát. 20 ezer forint az eddigi adomány.” [Gy.: Pesti utcán. In: Valóság. 1956. november 3. I. évf. 4. sz. 4. o.] A Magyar Világban: „Oktogon tér 1. sz. ház kapualja. Egy üres szovjet lőszeres láda a földön, a kapura plakát szögezve: »Tiszta forradalmunk lehetővé teszi, hogy így gyüjtsünk mártírjaink családtagjainak.« A megsegítésre szánt forintosok csengve hullanak be abba a löszeres ládába, amelyből talán még egy hete a zsarnokok halálthozó töltényeikkel ölték halomszámra szabadságharcosainkat.” [Az utcán. In: Magyar Világ. 1956. november 3. I. évf. 3. sz.] A Népakarat címlapon közli Gyulavári Béla fotóját, a következő képaláírással: „»Forradalmunk tisztasága megengedi, hogy így gyüjtsünk mártírjaink családjainak.« Aláírás: Magyar Írók Szövetsége - hirdeti szerte a városban a plakát. A nyomtatványra egy százforintost ragasztott valaki. Alatta zöld ládikó, s ebbe percről-percre hullik a pénz. Már telik a láda, de senkinek sem jutna eszébe, hogy hozzányúljon - pedig nem őrzi senki sem.” [Népakarat. 1956. november 3. I. évf. 3. sz. o.n.; két oldallal bentebb ismét az Őrizetlen pénzről szól a Népakarat.] A Kis Ujság a következőket írja: „Nyitott láda áll az Oktogon egyik kapualjában. Valaha lőszert, gyilkos golyókat tartottak benne egy ÁVHlaktanyában. Ezzel gyilkolták eszeveszett gyülöletükben forradalmunk hősi fiataljait, s most a láda, mely a halált hordozta méhében, kincset ölel vaspántos deszkái közt. Egy felszabadult nép szeretetének és áldozatkészségének ajándékát. Egy-, két-, tíz- és százforintosok hullanak bele. [...] Sírás fojtogat. Valamilyen megmagyarázhatatlan, túláradó ujjongás, amitől sós könnyek marják a torkot. Rég nem érzett indulatok, némaságra ítélt lélekharangok törnek fel és hangjuk betölti Budapest tereit és utcáit. Új emberség születik! Pillanatonként, ahogy egymás után csörrennek a ládába vetett forintok. Büszke vagyok rá, hogy magyar vagyok, hogy ott állhattam a kis diáklány Till Olga, a honvéd Nagy József mellett, mikor kopott pénztárcájuk tartalmát a ládába öntötték.” [Kiss Antal: Magasztos eszme. In: Kis Ujság. 1956. november 3. I. évf. 3. sz. 3. o.] És az Egyetemi Ifjúságban: „Egy láda pénz. A Rákóczi út sarkán - a gyógyszertár előtt - nagy a tolongás. Az emberek megállnak, megrendülten olvassák a falragaszt, majd tárcájukért nyúlnak. A járdán egy láda, hatalmas deszkaláda áll, tele van tíz, húsz, ötven és százforintosokkal. Egy láda pénz a forradalom árváinak a támogatására. A gyüjtés elindítója a Magyar Írók Szövetsége.” [Egyetemi Ifjúság. 1956. november 4. I. évf. 6. sz. o.n.] Lásd még a Magyar Szabadságnak a Magyar Nemzettel 
fontosabb is, amit az akció kapcsán a müvész(et) szerepéről mond Peternák Miklósnak:

Tehát ez, pont a művészi gondolkodás alkalmazása egy adott szituációban. Ha lelkesedésből, hirtelen

megközelítőleg azonos írását, valamint jóval későbbről Fekete Gyula sorait, aki úgy fejezi be a visszaemlékezést: „[N]em minden apró részletre emlékszem egyformán Erdély Miklóssal, de lényeget illetően nincs köztünk különbség." [Forradalmunk nagyszerü erkölcse. In: Magyar Szabadság. 1956. november 3. I. évf. 3. sz. 2. o.; Fekete Gyula: Tengercsepp. In: Magyar Fórum. 1992. március 12. IV. évf. 11. sz. 12. o.] Az Örizetlen pénz az utcán értelmezéséhez lásd még főként a következőket: György Péter: (Erdély Miklósról). Elhangzott a Szabad Európa Rádióban, 1991-ben. Kézirat, 1991.; György Péter: Erdély Miklós - A szelíd botrány müvésze. In: Holmi. 1992/8. sz. 1172-1173. o.; (Pachner): Több volt, mint müvészet. Hol rontottuk el? In: Pest Megyei Hírlap. 1992. október 26.; Boros Géza: Örizetlen pénz. Jövőkötvény. Két 1956-os konceptualista akció. In: Kritika. 1996/10. sz. 26-27. o.; Tillmann J. A.: Erdély Miklós és A kalcedoni zsinat. In: Uő: Meröleges elmozdulások. Utak a modern müvészetben. Új Palatinus-Könyvesház Kft., Budapest, 2004. 80. o. Interneten: http://www.c3.hu/ tillmann/irasok/muveszet/erdely.html; 2012. 11. 12. (A tanulmány korábbi, 1999-ben, a Magyar Mühelyben és a Pannonhalmi Szemlében közölt változatai többek közt éppen az Örizetlen pénzröl szóló sorokkal bővültek.); Peternák Miklós: Interdiszciplinaritás. Új médiumok az elmúlt három évtized magyar müvészetében - vagy kire hatott Erdély Miklós és kire nem? In: A második nyilvánosság - XX. századi magyar müvészet. Összeállította Hans Knoll. Enciklopédia Kiadó, Budapest, 2002. 251. o.; Németh Gábor - Sebők Zoltán: Az utca művészete. (Németh Gábor és Sebők Zoltán beszélgetése). In: Új Forrás. 2004. október, XXXVIII. évf. 8. sz. 99-102. o.; Müllner András: Az első happening. A magyarországi neoavantgárd akcionizmus vázlatos története. In: Né/ma? Tanulmányok a magyar neoavantgárd köréböl. Szerk. Deréky Pál és Müllner András. Ráció Kiadó, Budapest, 2004. 188-189. o.; Liszka Tamás: Szabadságtechnikai gyakorlatok. Erdély Miklós fogalmi müvészete és művészetfogalmai. In: Metropolis. 2007. április, XI. évf. 4. sz. 18-19. o.; Krusovszky Dénes, Urfi Péter: „Egy szük terem” (interjú György Péterrel). In: Puskin Utca. 2008/4. sz. 27. o.; Kicsiny Balázs: Óramotívum és eszkatológia. A mérhető és a mérhetetlen ábrázolása. DLA értekezés, Magyar Képzőmüvészeti Egyetem, Doktori Iskola, Budapest, 2008. 53. o. 
egy ilyen új morális jelenség megjelenik, azt észre kell venni a művésznek. Erre hangsúlyt kell tenni, ez a müvész feladata. ${ }^{227}$

Túl azon, hogy az Örizetlen pénz az 1956-os forradalom egyik kitüntetett eseménye volt, a történtek utólag szimbolikusan kiemelik Erdély törekvéseinek a magvát. Azt, hogy számára a művészet lényege az új, a még ismeretlen fürkészése és a frissen megjelenő szituációk korlátok nélküli feltárása. Azt, hogy a művészet a mindig éppen újra adott, konvencióktól mentes reakció és a közvetlenségével szelíden provokáló morális tartás.

Az Örizetlen pénzben elválaszthatatlan egymástól a társadalmi tudatosság és a müvészet. Csak utólag és csak a kérdőjelet meghagyva tehetjük fel a kérdést, hogy egyáltalán müvészeti munkának tekinthető-e? Hogy láthatjuk-e egyfajta proto-happenningként, avagy „őshappeningként”? ${ }^{228} \mathrm{~S}$ az esemény többek közt éppen azért kiemelkedő, mert ezt a kérdést semmiképp sem lehet a müvészet és az élet világát elválasztó címszavakkal megválaszolni. Csak részben lehet szétfejteni az egymást továbblendítő elemeket: a forradalmi közérzület felszabadító hatását, a novemberi bizakodó, tisztaságára büszke fellélegzést és a művészeti műfajok bevett határainak forradalmi semmibe vételét, a művészet által felhasznált tárgyak és gesztusok spontán feltörő szabadságát.

Erdély nem állt úgy szemben a rendszerrel, hogy világos, pozitív alternatívát kínált volna - ahogy ez egyébiránt az egész neoavantgárdról elmondható. De nem volt lázadó úgy sem, mint egy forradalmár. Viszont

227 Peternák Miklós: Beszélgetés Erdély Miklóssal 1983 tavaszán. In: Árgus. 1991. szeptember-október, II. évf. 5. sz. 86. o.

${ }^{228}$ Müllner András John Cage 1952-es akciójához, „cím nélküli eseményéhez” hasonlóan az Örizetlen pénzt ős-happeningnek tekinti. [I.m. 188. o.] 
semmiképp sem volt egy apolitikus, tisztán esztétikai kultúra híve sem. Nem egy politikai rendszer ellen lázadt, hanem szinte bármitől függetlenül vagy bármi mellett megvolt a saját, önmagát is bármikor, egyetlen mozdulattal revideálni képes véleménye. Az Örizetlen pénz az utcán egyszerre állt ki a rezsimet lerázni akaró forradalom mellett, és némileg elörevetítve a '68-as tavasz baloldali eszméit, egyszersmind tiltakozott a kapitalizmust megtestesítő pénz mindenhatósága ellen is. Erdély 1963-ban jutott ki első ízben Párizsba, ahol, mintha csak az '56-os akcióját formálta volna át a helyi kontextushoz, ismét pénzes akciót tervezett: frankot szándékozott árulni, valamivel a névértéke alatt. Kért is egy butik-helyet a Boulevard Saint-Germainen, ám a hatóságok - elmondása szerint - nem adtak engedélyt a pénzt devalváló akcióra. Az esetről és a pénz szerepének folyamatos értelmezéséről az Anarchisták Párizsban (Egy turista megrendülései) címü írásában számol be:

Ebből az egész párizsi mentalitásból arra következtettem, hogy a pénz az, ami tönkreteszi az embereket. [...] Meg kellene törni a pénz hatalmát, méghozzá egyetlen mozdulattal. Elképzelhetetlen, hogy egy ennyire elvont, életidegen, racionális számrendszeren alapuló konstrukció, mint a pénz világa, így kordában tudja tartani és ki tudja elégíteni a sokszorosan bonyolultabb vágyakból szövött emberi lelket. [...] Hogy ez a beidegzett őrület ne hordana magában annyi ellentmondást, amit mindenki érez, s amit egyetlen jól megválasztott akcióval nevetségessé ne lehetne tenni, hogy nem lényegi mivoltát ne lehetne leleplezni és kipukkasztani az egész hólyagot, ha jó ponton szúrjuk meg. A szocializmusban ugyanígy 200 Ft fizetésemelés érdekében vadulnak egymásnak az emberek, hánykolódnak végig álmatlan éjszakákat. Föllépett már avant-gardizmus minden ellen, de soha a pénz ellen [...]. Nem lenne elegendő, ha 10-20 szegény fiú elhullajtaná a pénzét Párizs utcáin és nyugodtan végignézné, míg mások mohón 
felkaparnák, nem követnék-e sokan inkább e felszabaduló fiúk példáját, mint a porban kotorászó harácsolókét? Vagy nem kellene-e árusítani magát a pénzt tetszőleges áron, $\mathrm{s}$ ezzel leszavaztatni a népeket a pénz kérdésében és megbélyegezni a pénz szégyenét örök idöre? Nem villanna-e minden, a pénzáruló bódé előtt elhaladó járókelő agyába a pénz szánalmas képtelensége? ${ }^{229}$

${ }^{229}$ Erdély Miklós: Anarchisták Párizsban (Egy turista megrendülései). In: MK. 35-36. o. Peternákkal beszélgetve némileg sarkosabban: „[...] [T]eljesen érthetetlen volt előttem az ottani, meghirdetett szabadság. A meghirdetett szabadságállapotok és az emberek viselkedése között nagyon erös kontrasztot éreztem. Tehát olyan volt mindenki ott, mintha íratlan szabályok szerint egy zsinóron lenne rángatva. Nem tudtam, mi az a fenomén, ami ezt szervezi. S akkor rájöttem, hogy a pénznek Nyugaton sokkal mélyebb beleívódása tapasztalható az idegrendszerbe, mint amit én itt megszoktam - Magyarországon.” Perneczky Géza tolmácsolásában: „Abból, ami érték, jobb, ha minél kevesebb van, mert eszmei értéke csak értéken alul növekedhet - vagyis csak a kioltott érték igazán értékes." [Perneczky Géza: Erdély Miklós, és mủve, a dekonstruktív tautológia. In: Erdély Miklós /1928-1986/. Kiállítási katalógus, Csók István Képtár, István Király Múzeum, Székesfehérvár, 1991. október 26. - december 31. 16. o.; Peternák Miklós: Beszélgetés Erdély Miklóssal 1983 tavaszán. In: Árgus. 1991. szeptember-október, II. évf. 5. sz. 77. o. Lásd még György Péter, Boros Géza, Tillmann J. A., Peternák Miklós és Müllner András fentebb említett tanulmányait, valamint Németh Gábor és Sebők Zoltán beszélgetését.]

Erdély felesége, Szenes Zsuzsa majd fél évet töltött Párizsban, s az utolsó másfél hónapra Erdély is kiutazott hozzá. Saját elmesélése szerint úgy éltek kint, hogy eleinte egy pohár vízre sem mindig tellett, majd ő is munkát kapott, egy épület tervezését bízták rá, s ekkor ötlött be neki a pénzakció gondolata. Erdély Dániel pedig azt meséli el, hogy szülei itt tudtak újra találkozni sok régi baráttal, akik '56-ban hagyták el az országot, és itt ismerkedtek meg egy franciatuniszi-zsidó társasággal, valamint a Nahmias családdal, akikről az Anarchisták Párizsban címủ írás szól. És a beszámolók szerint itt szakadt meg Erdély barátsága Pilinszky Jánossal, akit még a Saint-Germain körúton az Old Navy kávéház teraszán várt, hogy megérkezzen, hogy megkönnyítse az első lépéseit Párizsban, s akivel az első napokban még jó kedéllyel közös fotókat is készítettek egy igazolványkép-automatában. [Kondor, Erdély és Pilinszky kapcsolatáról, az 
A „pénz szánalmas képtelenségének” feldolgozásával jóval szelídebb formában később is találkozhatunk. 1979-ben, a Józsefvárosi Kiállítóterem fotogram-kiállításán szerepelt az Egy fecske ára címü munkája. ${ }^{230}$ Mindössze a fotogram fekete felületét látjuk, két nagyobb és két kisebb fehér körrel. A kép a lehető legbanálisabban ábrázolja azt, amire a címe tárgyszerüen utal: egy doboz Fecske füstszürős cigaretta árát. Erdély

'50-es évek végén még egy irányba, gyakran a hosszúra nyúló, alkoholgőzös pesti éjszakákba tartó barátságról, az építészpincéről, a betört körúti kirakatüvegekről, az elzavart rendőrről, a földre kényszerített katonáról, a nyers érzékenységről és a szókimondó különbségekről lásd: Ágh István: Föl-le a Ménesi úton. In: Magyar Nemzet. 1989. január 21. LII. évf. 18. sz. 11. o. Újraközölve: Uő: Virágárok. Kortárs Kiadó, Budapest, 1996. 50-57. o.; Uö: Kidöntött fáink suttogása. Nap Kiadó, Budapest, 2008. 299-304. o.; Konrád György: Pilinszky. In: In memoriam Pilinszky. Összeállította és az interjúkat készítette Bogyay Katalin. Officia Nova, Budapest, 1990. 86-88. o. Újraközölve: Uő: Csodafigurák. Arcképek, pillanatfelvételek. Noran Kiadó, Budapest, 2006. 5-11. o.; Beszélgetés Papp Tiborral (Párizs). In: In memoriam Pilinszky. Összeállította és az interjúkat készítette Bogyay Katalin. Officia Nova, Budapest, 1990. 69-71. o.; Kenedi János: Emberekről, eszmékről, politikáról. Csizmadia Ervin interjúja. 1. rész. In: Valóság. 1990. március, XXXIII. évf. 3. sz. 63-64. o.; Havas Fanny: Egy valódi mester. Beszélgetés Maurer Dórával. In: Beszélő. A senki földjén. A Beszélő melléklete Erdély Miklósról. 1991. október 26. Új folyam II. évf. 43. sz. 3. o.; Perneczky Géza: Produktivitásra ítélve? Az Iparterv-csoport és ami utána következett Magyarországon. 1. rész. In: Balkon. 1996/1-2. sz. 16. o.; Erdély Miklós Kondor Béláról. Részlet egy 1981 körül készült magnófelvételből. In: Beszélö. 1999. január, III. folyam, IV. évf. 1. sz. 104-115. o. A hangfelvétellel együtt lásd/hallgasd: http://artpool.hu/Erdely/Kondor.html; 2013. 07. 28.; „Kicsit úgy nézte ezeket a dolgokat, mint a tyúk a piros kukoricát...” Erdély Miklós Kondor Béla és az avantgárd kapcsolatáról - archív interjúszöveg 1983-ból. A beszélgetést készítette: Rényi András. A csak legépelt példányban fennmaradt szöveget gondozta, jegyzetekkel ellátta: Szőke Annamária. In: Müút. 2013/037. sz. 50-58. o.]

${ }^{230}$ Fotogramok. Józsefvárosi Kiállítóterem, Budapest, 1979. február 2-28. 
4 Ft 40 fillért tett rá egy DIN A4-es Dokubrom fotópapírra, ami a 2 db 2 Ftoson és a 2 db 20 filléresen kívül feketére égett. S a tiszta nyomrögzítő gesztus, a megörökítés tárgyiasult egyszerüsége mégis egy csapásra teszi világossá a gondolat ábrázolhatatlan költőiségét. A végletesen banális, szenvtelen ábrázolás időtlenségében világítja meg a rögzíthetetlent. ${ }^{231}$

Erdély Miklós a már említett alkotásain túl mindössze két olyan munkával jelentkezett Magyarországon az 1965 és ’70 közötti időszakban, melyeknek politikai, társadalomkritikai irányultsága is volt. Ezek a

231 Kicsit másként: a fotogram banalitása némi iróniával vegyülve eszünkbe juttathatja az időszak természettudományos kiadványainak képi világát is. A megannyi fényév távolságban lévő csillagokról készült, szinte abszurd, ismeretterjesztő fotókat, melyeken szintúgy csak a feketeséget és a fehér köröket, pöttyöket látjuk - esetleg egy-egy nyíllal, ami mutatja, hogy pontosasan melyik fehért kört kell néznünk. Ezek a fotók, amennyire képtelenek bármit is bemutatni, épp annyira kínálják fel az elérhetetlen, a mulandósággal összemérhetetlen örök utáni vágyódást. [Erdély fotogramjáról lásd még: Peternák Miklós: Képháromszög. Ráció Kiadó, Budapest, 2007. 174. o.]

S hogy egy történetet lezárjunk: itt, a Józsefvárosi Kiállítóteremben volt látható a Fekete nekrológ is, mely mintegy válaszként készült a '80-as évekig felemlegetett nekrológ-ügyre. A munka a megnyitó másnapjára eltünt, ám Erdély ismét elkészítette: lefotózta a Kondor Béláról megjelent nekrológot, majd a saját, ugyanakkora negatívjával letakarta azt. Így külön-külön, egymástól elemelve az újságot és a negatívot, mindkettőt el lehetett olvasni, egymáson azonban olvashatatlan, egységes fekete felületet hoztak létre. [Lásd: Szegő György: Az „igazság áramlási iránya”. In: Magyar Nemzet. 1988. október 25. LI. évf. 255. sz. 4. o.; Szegő György: Fotó/szeánsz: Erdély Miklós. In: Magyar Mühely. 1999. XXXVII. évf. 110-111. sz. 141. o.; Erdély Miklós Kondor Béláról. Részlet egy 1981 körül készült magnófelvételből. In: Beszélő. 1999. január, III. folyam, IV. évf. 1. sz. 113. o.; „Kicsit úgy nézte ezeket a dolgokat, mint a tyúk a piros kukoricát...” Erdély Miklós Kondor Béla és az avantgárd kapcsolatáról - archív interjúszöveg 1983-ból. A beszélgetést készítette: Rényi András. A csak legépelt példányban fennmaradt szöveget gondozta, jegyzetekkel ellátta: Szőke Annamária. In: Müút. 2013/037. sz. 52. o.] 
Szelídség medencéje és a Fiúingmerevitő. Mindkettő az 1970-ben rendezett

- a II. IPARTERV-tárlathoz hasonlóan rövid ideig látogatható - „R”kiállításon szerepelt. Erdély itt négy alkotását állította ki: az említett kettő mellett a Váza virággal és a Tavalyi hó című konceptuális munkáit. Ez utóbbiak, ahogy már írtam, Erdély életmüvében ugyancsak kitüntetett szereppel bírnak: markánsan mutatják, hogy a pályája elején még határozottan kötődött Duchamp-hoz, és rajta keresztül a konceptuális müvészethez. Most azonban nézzük meg a két politikai konceptet.

A Szelídség medencéje a következőkből áll: négy lécből és műanyag fóliából kialakított medence, a peremén körbevéve 49 db szorosan egymás mellé helyezett, kilyukasztott szovjet sürített tejkonzervvel, melyekből a tej a medence közepe felé folyik, ahol nagyobb élesztőtömbök között macesz, azaz élesztő nélküli, kovásztalan pászka van elhelyezve. A medence fölött még egy, de már címke nélküli konzervdoboz függ, ebből kondenzált tej helyett - tiszta víz csorog. ${ }^{232}$ Mit látunk itt? Nemcsak

232 A fennmaradt dokumentumok alapján történő rekonstruálás közel sem egyszerű. Erdély Miklós 1983-ból felidézve a kiállítást pontosan leírja a dobozokat, az azoktól kivezető orvosi gumicsöveket és a szaglászóhelyiséget, viszont 100 db tejkonzervre emlékszik, és kihagyja a vizet csorgató konzervdobozt. [Peternák Miklós: Beszélgetés Erdély Miklóssal 1983 tavaszán. In: Árgus. 1991. szeptember-október, II. évf. 5. sz. 80. o.] Beke László a mü leírásában szól a konzervből csorgó vízről is, azonban nem említi a konzervek csomagolását, ahogy a szaglászópont elhelyezkedését sem részletezi. [Beke László: Erdély Miklós munkássága. Krono-logikai vázlat képekkel 1985-ig. In: Erdély Miklós. Kiállítási katalógus, Óbuda Galéria, Zichy Kastély, 1986. április 11. - május 5. 7. o.; Beke László: Erdély Miklós. In: Híd. 1982/3. 381. o.] Szerencsére nagy számmal maradtak fenn fotók a kiállításról: ha ezek alapján Erdély munkájának nem is minden részletét, de sok mindet beazonosíthatunk. (A fotók túlnyomó többségét Berényi János, Galántai György és Zaránd Gyula készítette.) A pontosítás nehézségeiről, a Szelídség medencéjének 1998-as, 
különböző anyagok kémiai, hanem különböző kontextusok szimbolikus interakcióját is: ahogy a medence megtelik, a tejben és vízben ázó élesztő

Mủcsarnok-beli „kulissza-rekonstrukció”-járól pedig érdemes elolvasunk Szőke Annamária már-már anekdotikussá növő beszámolóját is. Eszerint '98-ban az első, több problémát felvető ötlet a konzerv-címkék legyártása, „szimulálása” volt. Ám ekkor Beke László véletlen találkozott az orosz nagykövettel, s kiderült, ennek a tejkonzervnek a gyártása még nem állt le. Következett a Soros Dokumentációs Központ moszkvai irodája és a Máltai Szeretetszolgálat, de a tejkonzerveket a megnyitóig nem sikerült beszerezni. Végül, kellő szerencsével és segítséggel kaptak egy mintapéldányt El Kazovszkijtól, melynek alapján legyárthatták a címkéket. Ekkor derült ki, hogy ezek kék színüek, s így valamifajta aleatorikus összhangban lesznek a medence anyagául választott kék fóliával (az eredeti színekre a szemtanúk sem emlékeztek). [Szőke Annamária: Erdély Miklós müveinek restaurálása és rekonstrukciója. In: Magyar Mühely. 1999. XXXVII. évf. 110-111. sz. 127-128. o. Lásd még: Beke László: KENTAUR. In: Magyar Mühely. 1978. június, XVI. évf. 54-55. sz. 84. o. Újraközölve: In: Mozgó Film 2. A BBS Mühelykiadványa. Szerk. Forgács Péter. A „K” rovatot szerkesztette: Beke László. Balázs Béla Stúdió, Budapest, 1986. 230. o.; Szőke Annamária: Tapogatózás legyen. In: Célok. 1989. január, II. évf. 2. sz. 22. o. Az egykorú kritikából lásd: Vadas József: Új magyar avantgarde? In: Új írás. 1971/5. sz. 99. o.; Rózsa T. Endre: Az utak összeérnek? In: Kritika. 1971/6. sz. 56. o. Újraközölve: In: Ars Hungarica. 1991/1. sz. 128. o.; Mezei Ottó: Háromnapos bemutató a Mủegyetem R épületében. (Kézirat a hagyatékban, 1970-1971) In: Uő: Magyar, európai, modern. Válogatott írások. Vál. és szerk. Andrási Gábor, Pataki Gábor. Argumentum Kiadó, MTA Bölcsészettudományi Kutatóintézet, Mủvészettörténeti Intézet, 2013. 251. o. A kiállítás rekonstrukciójáról lásd: Greskovics Eszter: Az „R”-kiállítás (1970) rekonstrukciója. In: Balkon. 2014/1. sz. 9-13. o. A Szelídség medencéje cím, mellyel a recepcióban névelővel és névelö nélkül is találkozhatunk, egyetlen fellelhető fotón sem szerepel - ami felveti annak a lehetôségét is, hogy az environmentnek egyszerüen eltünt a felirata a kiállításon. Ez pedig magyarázná nem csupán a különböző címvariánsokat, de azt is, hogy az egykorú kritikában ez a munka csak és kizárólag cím nélkül szerepel. (A Fiúingmerevitő, melynek közvetlenül a kiállítás után különböző, kötőjellel írt variánsai terjedtek el - Fiú-ingmerevitö, Fiúingmerevitő -, a fotókon egybeírva olvasható.) Ezúton is köszönöm Greskovics Ezter segítségét.] 
erjedni kezd, s a maceszből ázott kenyér, de macesz sem lesz. Ez az environment első megközelítésre nem a jelentéskioltás útján tereli a befogadóját, nem az egymást kioltó jelentések nyomán feltárulkozó üresség felé vezet. A néző ehelyett az eizensteini montázsmatematika metamorfózisával találkozhat: azzal, hogy az összetevők nem egyszerüen összeadódnak, de nem is zárójelezik egymást, hanem új minőséget, esetünkben új halmazállapotot hoznak létre. Ez is megfoghatatlan, mint az üresség, azonban nagyon is van: jele a termelődő bűz. Sőt, a termelődő bűz nem is csupán jele, hanem eredménye a „jelkonzervek” ${ }^{233}$ elegyének: a macesznak, az élesztőnek, a szovjet sürített tejnek és a víznek. Erdély a termelődő gázt két gumicsövön keresztül egy szaglászóhelyre vezette, egy asztalra helyezett negatív gipszorrba - melyet nem mellékesen a saját arcán öntött ki -, s a közelbe egy feliratot tett: „Itt gáz lesz”. Az anekdota szerint Aczél György, a „pater familias” is odament a szaglászóponthoz, az orrát bele is tette a mintába, majd másnapra a tárlatot bezáratta. ${ }^{234}$

233 „[Édesapám] [s]zakértő szemmel válogatta ki a spárgákat, hintőporokat, lámpákat és jelkonzerveket. Elnézést - tejkonzerveket.” [Erdély Dániel: „Mi kis” életünk. In: Árgus. 1991. szeptember-október, II. évf. 5. sz. 95. o.]

${ }^{234}$ Peternák Miklós: Beszélgetés Erdély Miklóssal 1983 tavaszán. In: Árgus. 1991. szeptember-október, II. évf. 5. sz. 80. o. Aczélt ezen a tárlaton Harasztÿ István vezette körbe: „Oda [az R Klubba] eljött Gyuri bátyánk is. Én kalauzoltam végig. Közvetlen modorban, emberi hangon igyekeztem neki elmondani, hol mit szeretnénk kifejezni, semmi rosszat nem akarunk, csak ugye, ehhez értünk, ezért csinálunk ilyesmiket.” [Szőnyei Tamás: „Hátha felfedezem az örökmozgót”. Harasztÿ István szobrászmüvész. (Interjú Harasztÿ Istvánnal.) In: Magyar Narancs. 1998. május 21. X. évf. 21. sz. 9. o. Az engedélyezés és betiltás kérdésének lehető legpontosabb tisztázását lásd: Greskovics Eszter: Az „R”kiállítás (1970) rekonstrukciója. In: Balkon. 2014/1. sz. 9-13. o.] Ha már az 1998as rekonstrukció anekdotáját felelevenítettük, folytassuk is kicsit: Erdély 1970ben a megnyitó akciójaként maga szúrta ki a konzerveket, maga indította el a 
A szaglászóhely a nézőt ambivalens helyzetbe hozza. Egyfelől stabil kívülállást kínál fel, olyan helyet, ami a történésen, az „ügyön” kívüli. Ugyanakkor a póz, amiben szaglászni lehet - és itt a konkrét testhelyzetre gondolok - mégiscsak kiszolgáltatott. A néző, ha szaglászni akart, széken ülve kellett fejét az asztalra ráhajtania. Kényelmetlenségét pedig csak fokozhatta, ha a medencéböl a negatív orrig vezető két piros gumicső konnotációit maga felé érezte terjedni, ugyanis ezeknek a csöveknek a leggyakoribb funkciója az erek elszorítása. ${ }^{235}$

folyamatot, amit '98-ban már nem lehetett megtenni - de nem is csak azért, mert Erdély személyes érintettsége is hozzátartozott volna a gesztushoz, hanem mert végül üres konzervek kerültek a medence szélére. A medencét elöször tejjel öntötték fel, ami másnapra megaludt, majd tubusos sürített tejjel, ami repedezettre szikkadt, de legalább stabilan kitartott. Az interakció és a termelődő gáz így 1998-ban már elmaradt. [Szőke Annamária: Erdély Miklós műveinek restaurálása és rekonstrukciója. In: Magyar Mühely. 1999. XXXVII. évf. 110-111. sz. 127128. o.]

${ }^{235}$ Mi pedig a kívülálló, kibic értelmezői póz kényelmetlenségéhez idézhetjük Erdély ebben az évben készült montázsfilmjének, az Antiszempontnak a szövegét: „Nh [Női hang]: Hogy kell v a l a k i t megbüntetni? Fh [Férfi hang]: Hogy kell valakit megbüntetni? Nh: Alakoskodásra kell kényszeríteni. Fh: Álokoskodásra kell kényszeríteni. Nh: Alakoskodásra kell kényszeríteni. Fh: Álalakoskodásra kell kényszeríteni.” [Erdély Miklós: Antiszempont. In: KO. 80. o. A filmet többnyire 1971-es dátummal tüntetik fel, azonban a bemutatójára már az „R”-kiállítás előtt bő nyolc hónappal, 1970. április 6-án sor került a Bem rakparti esték 7. keretében az I. kerületi Mủvelődési Házban, s ennél még valamivel korábban született Erdélynek a film alapjául szolgáló, azonos címü hangjátéka.]

Egy ravasz módon felkínált interpretáció szerint a Szelídség medencéje tulajdonképpen már a címében is tisztelgés a kádári politika előtt, amely megállította a szocialista blokk országain ekkor végigsöprő antiszemita hullámot Magyarország határainál. S ennek alapján Erdély munkájára, még ha kényszeredett mosollyal is, de a parvenü Aczélnak - a zsidó cserkészcsapatból lett, majd a Rákosi-érában betiltott baloldali cionista ifjúsági mozgalomhoz, a Somérhoz még a ’30-as években 
csatlakozott Appel Henriknek, mozgalmi nevén Joélnek - is feltétlenül bólintania kellett volna. Csakhogy ez az értelmezés zavarba ejtően kényelmetlen. Kényelmetlenségét pedig a személyes érintettségen túl természetesen az okozza, hogy legalább olyannyira álságos, mint a „zsidókérdés” honi, aktuális kezelése. Hogy a cím mögötti environment, ahogy az ekkori hivatalos szólamok mögötti élet is, ennél jóval összetettebb. Az 1967-es hatnapos arab-izraeli háború után Magyarország a szovjet elvárásoknak megfelelöen felsorakozott Izrael elítélése mellett. Az Izrael-ellenes politika elfogadtatása azonban egyáltalán nem volt könnyű feladat. A feljegyzések szerint, habár nem alakítottak ki különutat, s a véleményükről egyébként is inkább csak hallgattak, ez még a kommunista zsidóságban is komoly zavart okozott. A hitközségi vezetők pedig, habár Szovjetunióval és a tábor legtöbb országával ellentétben nem voltak megalázó módon arra rákényszerítve, hogy nyíltan kiálljanak a „zsidó állam agresszióját" elítélő hivatalos politika mellett, végül teljes mértékben kiszolgálták ezt az irányvonalat. Igazolásul az szolgált számukra, hogy az anticionizmus Magyarországon nem fordult át antiszemitizmusba. Hogy a Lengyelországot és Csehszlovákiát is elérő nyílt, még a párt által is támogatott antiszemita hullámnak csak a híre, illetve szórványos „lelátó- és kocsma-rigmusai” jutottak el Magyarországra. Az Izrael melletti szimpátiát ugyanakkor nem lehetett minden szinten elfojtani. A „fiatalokat megtévesztő" renitens rabbikat vagy épp csak a kulturális életet szervezni próbálókat többnyire maga a hitközség fegyelmezte meg, Scheiber Sándort, a Rabbiszeminárium vezetőjét, Geyer Artúr förabbit, Raj Tamás szegedi rabbit és a fiatalok önszerveződő csoportjait pedig mint cionista veszélyforrásokat természetesen az állami szervek is figyelemmel kísérték. Az állampárt végül - a Kádár-korszaknak megfelelően - egyetlen esetben sem alkalmazott kemény retorziót. Feltehetően nem is törekedtek rá, de a hitközségi szervek hathatós együttmüködése miatt nem is volt erre szükségük. Ezzel együtt tovább nőtt az addig sem kicsi távolság a magyarországi zsidó intézmények és a magyar zsidóság, főként az identitásukat kereső fiatalok között akiknek a hangja elöször nyíltan csak jóval később, a '80-as évek közepén, a zsidó intézményeken kívül és a pártállammal szemben szólalt meg. [Lásd föként: Kovács András: A zsidókérdés a mai magyar társadalomban. In: Zsidóság az 1945 utáni Magyarországon. Szerk. Kende Péter. Magyar Füzetek, Párizs, 1984. 3-35. o.; Arje Palgi (Fleischmann László): Aczél György és a zsidóság. (Aczél György 1989-ben Izraelben tett kéthetes látogatása nyomán, a „makacs öreg zsidó megtéréséről”.) In: Szombat. 1990. augsztus, I. évf. 6. sz. 13-14. o.; Csorba László: Izraelita felekezeti élet Magyarországon a vészkorszaktól a nyolcvanas évekig. In: Hét évtized a hazai zsidóság életében II. Szerk. Lendvai L. Ferenc, Sohár Anikó, Horváth Pál. MTA Filozófiai 
Erdély Miklós a Fiúingmerevitővel is valami olyat tett ki az asztalra, aminek ezekben az években többnyire az asztal alatt volt a helye. Erdélynek és munkáinak a szituációérzékenységét mutatja, hogy a tabuk konfrontatív kiállítása nemcsak a hivatalos kultúrpolitika számára volt elfogadhatatlan, hanem a magyarországi tárlatlátogató közönségnek is zavarba ejtő lehetett. ${ }^{236}$ 1983-ban Antal Istvánnal beszélgetve úgy fogalmaz, hogy „az érdekes, ami kínos”. ${ }^{237}$ Erről a mondatról pedig utólag gondolhatjuk azt, hogy az alkotói szándék feltehetően el is érte célját. Csakhogy munkái - a teljesebb intenciójuk szerint - nem merülnek ki a feldolgozatlannal való puszta szembesítésben, az egyszerủ provokációban.

Intézet, Budapest, 1990. 61-190. o.; Kovács András: Magyar zsidó politika a háború végétől a kommunista rendszer bukásáig. In: Múlt és Jövő. 2003. XIV. évf. 3. sz. 5-39. o.; Heller Ágnes: A „zsidókérdés” megoldhatatlansága. Miért születtem hébernek, miért nem inkább négernek? Múlt és Jövő Kiadó, Budapest, 2004. 13-48. o.; Györi Szabó Róbert: Zsidóság és kommunizmus a Kádár-korszakban III. Zsidóság, cionizmus, antiszemitizmus az 1967-es arab-izraeli háború utáni években. In: Valóság. 2008. május, LI. évf. 5. sz. 79-97. o.; Bibó István: A zsidókérdésről. Szerk. Balog Iván. Argumentum Kiadó - Bibó István Szellemi Műhely, Budapest, 2010. 234-243. o.]

${ }^{236}$ Szabó Júlia a tárlatról csak röviden ír, de éppen ezt a munkát emeli ki: „Amikor Erdély Miklós kiállította az egyetemen egykori cserkészingét, nagy botrány lett belőle, pedig a művész csak valami hasonlót mondott el a vizualitás nyelvén a magyar történelemről, mint például Örkény István drámái és egypercesei.” [Szabó Júlia: Emlékek a 70-es évekből. In: Müvészet. 1980. október, XXI. évf. 10. sz. 10. o. Lásd még: Mezei Ottó: Háromnapos bemutató a Mủegyetem R épületében. (Kézirat a hagyatékban, 1970-1971) In: Uő: Magyar, európai, modern. Válogatott írások. Vál. és szerk. Andrási Gábor, Pataki Gábor. Argumentum Kiadó, MTA Bölcsészettudományi Kutatóintézet, Művészettörténeti Intézet, 2013. 253. o.]

${ }^{237}$ Krónika. (Erdély Miklós és Antal István beszélgetése a Verzióról). In: AF. 246. 0 . 
Erdély reményei szerint ugyanis: „[...] [C]sak az tud újra és jobban elrendeződni, ami fel van kavarva.”238

A Fiúingmerevitő egy macesztáblával kibélelt cserkészing - ismét csak nem mellékesen Erdély saját, egykori cserkészinge. ${ }^{239}$ A Szelídség medencéjének sokrétű, komplex jelentésrétegeihez mérten ez az objekt jóval egyszerübb módon, az ellentétezés tömörségével hat. Az ellentétek síkjait végigkövethetjük a tárgyat összetevő anyagoktól, azok formáitól a kiállítási tárgy és a kiállítási tér kontextusáig. Ebben a munkában az ing puhasága, kényelme konfrontálódik a macesztábla merevségével, az ing kockás mintája, a négyzetrács szigorúsága a maceszen szétfutó kerek, égett foltokkal, az ing háromszögletű „HUNGÁRIA”-felvarrója a macesszal mint a zsidóságnak, az egyiptomi kivonulásnak, a szenvedés és jogtalanság elviselésének és az időrétegek egymásra rakódásának szimbólumával. ${ }^{240}$ Maga az objekt pedig konfrontálódik a kiállítás terével, a Müszaki Egyetemmel - ezzel duplán, két felületen is. Erdély 1981-ben, az Apokrif

\footnotetext{
${ }^{238}$ Uo. 247. o.

${ }^{239}$ Erdély a ’30-as évek végén lett tagja a Vörösmarty Cserkészcsapatnak, a budai izraelita hitközösség négy őrsből álló cserkészcsapatának. A csapat feloszlása előtt nem sokkal őrsvezető lett a lelkiismeret-gyakorlatok, a sport és a kirándulások mellett főként zenével, operákkal, de az építészettel, képzőmüvészettel, irodalommal és a pszichoanalízissel is foglalkozó, társaikkal egymásnak előadásokat tartó őrsben. [Erdélyről és a cserkészcsapatról lásd még: Erdély Dániel: Mi kis családunk. In: Árgus. 1992. január-február, III. évf. 1. sz. 90-102. o.; Havas Fanny: Egy valódi mester. Beszélgetés Maurer Dórával. In: Beszélő. A senki földjén. A Beszélö melléklete Erdély Miklósról. 1991. október 26. Új folyam II. évf. 43. sz. 4. o.; Szipőcs Krisztina: Történetek Erdély Miklósról. In: Balkon. 1998/11. sz. 4-8. o.]

${ }^{240}$ A macesz müalkotásokban való használatának ön-értelmezéséhez lásd: Erdély Miklós: Előadás a kiállításról. (Magnófelvétel után). In: MI. 148. o., 152. o.; Peternák Miklós: Beszélgetés Erdély Miklóssal 1983 tavaszán. In: Árgus. 1991. szeptember-október, II. évf. 5. sz. 80. o.
} 
előadásban úgy emlékszik: „[...] [A] Mủegyetemnek volt egy antiszemita hangulata. [...] Antiszemita ajtókat láttam ott mindig, és azt, hogy az ébredő magyarok ott jöttek, valahogy úgy éreztem, hogy ezzel is valamiféle finom kapcsolatba kerül ez a helyzet, amibe én ott kerültem. Én speciel Rákosi alatt jártam a Műegyetemre, amikor ezek a szempontok igen homályosak voltak.”241 A kiállítás szituációja viszont ennél rétegzettebb volt, az ütközőfelület nem csak az antiszemitizmus tisztázatlan burka lehetett. Az 1983-as interjújában Erdély azt idézi fel, hogy zsidó cserkésztársai közül „majdnem mind a vad, dogmatikus irányzathoz csatlakozott az ötvenes években. Szabolcsi Miklós, aki ott volt [az „R”kiállításon], rögtön magára ismert.”242 Tehát a Fiúingmerevítőt többen

241 Erdély Miklós: Apokrif előadás. Elhangzott az Új irányzatok napjaink müvészetében címü, Körner Éva által szervezett TIT mủvészettörténeti előadássorozat keretében, 1981. december 2-án, az FMK-ban. (A fluxus és a happening téma kapcsán Erdély saját, 1981. november 25-én, a Müegyetemen megtartott akciójáról.) In: MI. 166. o. Mindenképpen idéznünk kell itt Erdélynek egy bő másfél évvel korábbi, A kalcedoni zsinat emlékére címü environmentjéhez készült akciójában elhangzott mondatát is: „Még sose láttam szemet, amiben az a bizonyos antiszemita mérgezés lett volna, mint közvetlen személyes erő.” [Erdély Miklós: Előadás a kiállításról. (Magnófelvétel után). (Bercsényi Kollégium, Budapest, 1980. március 18.) In: MI. 153. o.]

242 Peternák Miklós: Beszélgetés Erdély Miklóssal 1983 tavaszán. In: Árgus. 1991. szeptember-október, II. évf. 5. sz. 80. o. 1981-ben hasonlóan erős szavakkal említi Eörsi Istvánt is, „[...] Eörsi Pistit, aki szintén benne volt ebben az őrsben, az enyimben, csak kilépett egy idő múlva, mert sztálinista lett, és emiatt összevesztünk [...].” [Erdély Miklós Kondor Béláról. Részlet egy 1981 körül készült magnófelvételből. In: Beszélö. 1999. január, III. folyam, IV. évf. 1. sz. 105. o. A hangfelvétellel együtt lásd: http://artpool.hu/Erdely/Kondor.html; 2013. 07. 28. Ehhez pedig lásd: Erdély, az ellenguru. A művészet föltalálója. Legjobb barát, legjobb ellenség. (Dobai Péterrel, Eörsi Istvánnal, Konrád Györggyel, Litván Györggyel, Nagy Tamással és Rajk Lászlóval beszélget Váradi Júlia.) In: 168 Óra. 1991. november 5. III. évf. 44. sz. 32-33. o.] 
magukra vehették úgy, hogy közben érezték annak szúrós kényelmetlenségét: az ing merevsége áttételesen összefüggött az antiszemitizmussal, az anticionizmussal és az izraelita hitközösségből a dogmatikus politikához csatlakozókkal is. A Fiúingmerevítő egymással szembenálló attitüdöket helyez egymás mellé, de úgy, hogy a közvetlen összekapcsolás tárgyiasult gesztusa a szúrós konfrontáció pedzegetésén túl sejtetni engedi az ellentét tagjainak komplementer, egymástól nem független, egymással érintkező, akár egymást magyarázó viszonyát is.

Erdély Miklós műveihez elválaszthatatlanul hozzátartozik az alkotójuk is. Mielőtt azonban ezt a fajta jelenlétet, az autoriter magatartás minduntalan meglévő hangsúlyát egy stabil, a müértelmezéseinket segítő támpontnak vélnénk - és ezt egyúttal akár a történeti avantgárd hozadékának tekintenénk -, látnunk kell, hogy az alkotó azonosításával folyamatosan gondban vagyunk. Erdély munkáinak felfejtéséhez kikerülhetetlenül hozzátartozik az alkotójuk körvonalazása is. Ugyanakkor az erre irányuló törekvéseink, úgy tünik, sohasem érhetik el céljukat. Erdély műveinek alkotója ugyanis mindig máshol van, mint ahol mi: a folyamatos irányváltás és a folyamatos önkioltás állapotában. ${ }^{243}$

\footnotetext{
${ }^{243}$ Lásd még Erdély Dániel, Mújdricza Péter és Szenes Zsuzsa beszélgetését Erdély Miklós $\sqrt{-1}$ címü festményéről mint önarcképről és sok minden másról: Erdély Dániel, Mújdricza Péter, Szenes Zsuzsa: $\sqrt{-1}$, mint ANTIBÁLVÁNY, avagy a mélypont ünnepélye. Beszélgetés Erdély Miklós mütermében. In: Pompeji. 1993/1-2. sz. 78-115. o. Valamint: Forgács Éva: „,.. a nem elvárható dolgok megjelenítése”. Erdély Miklós életműkiállítása. In: Magyar Napló. 1991. november 29. III. évf. 16. sz. 34-35. o.; Petőcz András: A titok. Jegyzet Erdély Miklósról. In: Balkon. 1998/10. sz. 20-21. o.; Ungváry Rudolf: A személyes mủvész. Erdély Miklós nem triviális helye a struktúrában, avagy A találékonyságba belekapaszkodó ember. In: Magyar Mühely. 1999. XXXVII. évf. 110-111. sz. 176-188. o. Újraközölve: In: Kritika. 1999/2. sz. 34-36. o.
} 
Az 1969-es II. IPARTERV-tárlat katalógusába szánta Erdély az Eskü című fotómontázs-sorozatát. ${ }^{244} \mathrm{~A}$ hat fotómunkából álló sorozaton Erdély esküre emelt kézzel áll, más-más nagyításban, Schrödingeridézetekkel a mellkasára „vetítve”. Az idézetek a Heisenberg-féle határozatlansági elv alapjait elevenítik fel, azaz annak a felismerésnek az előzményeit, hogy amennyiben pontosan ismerjük egy elektron sebességét, nem vagyunk képesek helyzetének precíz megállapítására - és fordítva. Tehát azt, hogy lehetetlen egy részecske impulzusát és téridőben elfoglalt pozízióját egyszerre és pontosan megmérni. ${ }^{245}$ Bartholy Eszter pedig azt

244 A kiállítás kvázi katalógusa az IPARTERV-kiállítások összevont katalógusaként, antológiájaként jelent meg 1970-ben. Végül Erdélytől nem ez a munka került bele, hanem a már említett Molluszkum fotói. Most azt idézzük fel, miért nem ez: „[...] Konkoly végig tiltakozott ez ellen, hogy ezt nem hajlandó beletenni a katalógusba. Ilyen nincs. »Az attitűd formát ölt« címü katalógus volt akkor divatban, nekem meg is volt... Azt mondta, és akkor egyszer megfogalmazta nekem precízen: Vagy ez érvényes - a te munkád -, s akkor az összes többi nem, ami a katalógusban van, vagy ez nem érvényes, s akkor a többi marad.” [Peternák Miklós: Beszélgetés Erdély Miklóssal 1983 tavaszán. In: Árgus. 1991. szeptember-október, II. évf. 5. szám. 78. o.; LIVE IN YOUR HEAD. When attitudes become form. (Works, processes, concepts, situations, information.) Kunsthalle Bern, Bern, Svájc, 1969. március 22. - április 27. Kurátor: Harald Szeemann]

245 Ahogy Schrödinger írja: „[...] [A] részecske nem individuum többé, nem azonosítható önmagával [...].” [Erwin Schrödinger: Válogatott tanulmányok. Vál. és szerk. Tőrös Róbert. Ford. Nagy Imre. Gondolat, Budapest, 1970. 90. o.] Heisenberg: „Vagy a helyet lehet nagyon pontosan megmérni, akkor a megfigyelő műszer beavatkozásának következményeképpen a sebesség bizonyos mértékben elmosódik; fordítva viszont pontos sebességméréssel elkenődik a tartózkodási hely ismerete olyképpen, hogy a két bizonytalanság szorzatának a Planck-féle állandó alsó határt szab." [Werner Heisenberg: A mai fizika világképe. In: Uő: Válogatott tanulmányok. Ford. Morlin Zoltán. Gondolat, Budapest, 1967. 46. o. Lásd még: Roger Penrose: A császár új elméje. Számítógépek, gondolkodás és a 
idézi fel, hogy Erdély „egyik előadása alkalmával fölszólította a hallgatóságot, hogy esti imaként minden nap mondja fel magának [Russell halmazelméleti paradoxonát], mert azzal saját hétköznapi racionalizmusát oly módon kezdi ki, ami majdnem egyenlő az áhítattal.”246 A Russell-féle paradoxon pedig a következő: „Tekintsük azoknak az $x$ halmazoknak az $A$ halmazát, amelyek nem elemei önmaguknak: $A=\{x, x \notin x\}$. На $A \in A$, akkor $A$ definíciója szerint $A \notin A$, ellentmondás. Ha $A \notin A$, akkor ugyancsak $A$ definíciója szerint $A \in A$, ellentmondás.”247 $\mathrm{S}$ a

fizika törvényei. Ford. Gálfi László. Akadémiai Kiadó, Budapest, 2011. 327-329. o. Erdély munkájáról lásd még Szőke Annamária és Hornyik Sándor némileg etérő értelmezését: Szőke Annamária: „Titok a jövő jelenléte”. Tudomány a művészet határain belül Erdély Miklós müvészetében. In: Né/ma? Tanulmányok a magyar neoavantgárd köréböl. Szerk. Deréky Pál és Müllner András. Ráció Kiadó, Budapest, 2004. 248-252. o.; Hornyik Sándor: Naiv realizmus és „természettudományos koncept”. A modern természettudomány helye Erdély Miklós művészetében. In: Magyar Mühely. 2004. XLIII. évf. 131. sz. 37. o.]

${ }^{246}$ Bartholy Eszter: Erdély Miklós: Bújtatott zöld. In: Magyar Mühely. 1983. július, XXI. évf. 67. sz. 65. o.

${ }^{247}$ Simonovits András: Válogatott fejezetek a matematika történetéböl. TYPOTEX Kiadó, Budapest, 2009. 136. o. Russell paradoxonáról lásd még: Hajnal András, Hamburger Péter: Halmazelmélet. Nemzeti Tankönyvkiadó, Budapest, 1994. 1415. o.; R. M. Sainsbury: Paradoxonok. TYPOTEX Kiadó, Budapest, 2002. 150154. o.; Vekerdi László: Pillanatképek a „hatvanas évek” természettudományairól. In: Hatvanas évek. Új törekvések a magyar képzömüvészetben. Kiállítási katalógus, Magyar Nemzeti Galéria, 1991. március 14. - június 30. Összeáll. Beke László, Dévényi István, Horváth György. Szerk. Nagy Ildikó. Képzőművészeti Kiadó - Magyar Nemzeti Galéria - Ludwig Múzeum, Budapest, 1991. 11-20. o.; Szőke Annamária: „Titok a jövő jelenléte”. Tudomány a müvészet határain belül Erdély Miklós müvészetében. In: Né/ma? Tanulmányok a magyar neoavantgárd köréböl. Szerk. Deréky Pál és Müllner András. Ráció Kiadó, Budapest, 2004. 240-272. o.; Hornyik Sándor: A fekete lyukak esztétikája. Kritikai teória és praxis Erdély Miklósnál. In: Balkon. 2006/6. sz. 4-10. o.; Hornyik Sándor: Naiv realizmus és „természettudományos koncept”. A modern 
határozatlansági elvnek, illetve Russell halmazelméleti paradoxonának Erdély Miklóshoz igazításával máris az „R”-kiállításnál vagyunk.

Erdély Miklós munkáihoz sok esetben hozzátartozik a közvetlen, testi jelenlét is. Erdély nem csupán az akcióiban van jelen, a kiállítási tárgyait is gyakran akcióval burkolta körbe, avagy szövegeket készített hozzájuk, melyeket ő maga olvasott fel - és persze máshogy mondva: szövegeket írt, melyeket konceptuális, azaz a gondolatiságra fókuszáló akciókban vitt színre. ${ }^{248}$ Egy szó, mint száz, testi jelenléte is hozzátartozott munkáihoz. A Fiúingmerevitóben a saját testén viselt cserkészingét állította ki, ahogy a szaglászóhelyen saját orrának negatív lenyomata volt. Viszont hiába az ing és a lenyomat, a gazdáját nehéz megtalálnunk. Egyfelől mondhatjuk - és mondanunk is kell -, hogy az élesztő erjedésének átható szagát az az ember szimatolta, aki Óriás Aranka és Erdély István gyermekeként született 1928. július 4-én. Az az ember, akinek egy édestestvére, György, és három féltestvére, László, Ferenc és István közül csupán az egyik, István tért haza a munkaszolgálat és a koncentrációs tábor megpróbáltatásaiból. Az a traumatikus élményeket magával görgető ember,

természettudomány helye Erdély Miklós mủvészetében. In: Magyar Mühely. 2004. XLIII. évf. 131. sz. 16-50. o.]

248 „[...] [S]emmiféleképpen nem érzem magam igazán sem a performance-hez, sem a happeninghez tartozónak; az az érzésem, hogy mindezzel csak érintőleges kapcsolatom van. Arról van szó, hogy bizonyos gondolatmeneteket fölerösítek akciókkal vagy éppen ellenük dolgozom, de visszatekintve akcionalista magatartásomra, mindig a fogalmi szinten volt a hangsúly, és maga az akció ennek mindig a második szólamát képezte. Vagy úgy, hogy ellene dolgozott, vagy úgy, hogy bizonyos hangsúlyokat tett rá, vagy úgy, hogy kioltotta azt, amit mondok. Ez áll legközelebb a meggyőződésemhez." [Erdély Miklós: Apokrif előadás. In: MI. 154. o.] 
akinek az egész családját szörnyű veszteségek érték. ${ }^{249}$ Ha ezt mondjuk, feltétlenül igazunk van. De legjobb esetben is csak félig. Tudnunk kell,

${ }^{249}$ Erdély Miklós és családja veszteségeiről lásd: Erdély Miklós - Beke László: Egyenrangú interjú. 1978. április 16. In: Hasbeszélö a gondolában. A Tartóshullám antológiája. (Jóvilág 3.). (Cápa 4.). Szerk. Beke László, Csanády Dániel, Szőke Annamária. Bölcsész Index, Budapest, 1987. 185. o.; Erdély Dániel: „Mi kis” életünk. In: Árgus. 1991. szeptember-október, II. évf. 5. sz. 89100. o.; Erdély Dániel: Mi kis családunk. In: Árgus. 1992. január-február, III. évf. 1. sz. 90-102. o.; William McCagg: A nem-zsidó zsidó a modern Magyarországon. A zsidóság reakciójának felmérése a magyar antiszemitizmusra. „Burzsoá radikálisok”. „Atomtudósok”. „Erdély Miklós”. Esszé a magyar-zsidó koexistencia 1848-1991-ig c. kollokvium céljaira. Kézirat, Batthyány Társaság, Budapest, 1991. október; Péntek Imre: Erdély Miklós: A művészsors tiszta modellje. Beszélgetés feleségével, Szenes Zsuzsa textiltervező iparművésszel. In: Fejér Megyei Hírlap. Erdély Miklós kiállítása elé című összeállítás. 1991. október 26.; Szipőcs Krisztina: Történetek Erdély Miklósról. In: Balkon. 1998/11. sz. 4-8. 0 .

Erdély 1962-ben írta meg a Varga Anna dicsérete címü játékfilm-tervet, melyet 1963-ban Túlélni címen tovább bővített. A filmtervek 1944-45-be, a megzavarodott történelembe vezetnek vissza. Az ostoba, magabiztos erőszakhoz, az onnan szökni vágyók lemészárlásához, a menlevelek várásának izgalmához, a jótevőkhöz és a tiszta szerelemhez. Oda, amiről Erdély úgy gondolja: „Jól tesszük, ha e témakörben nem kíméljük ízlésünket és a legerősebb színekkel dolgozunk [...], mert a még mindig lobogó sokféle indulat csak szenvedéllyel szólítható meg.” [Erdély Miklós: Varga Anna dicsérete. In: AF. 67-72. o.; Erdély Miklós: Túlélni. In: AF. 80-87. o. Az idézet a Túlélni címü forgatókönyvhöz készült magyarázatból származik, melyet Erdély a Hunnia Stúdió dramaturgiai részlegének kérésére írt. Lásd: Peternák Miklós: Jegyzetek, dokumentumok. In: $A F .45$. o.] A fájóan közvetlen személyes érintettséghez pedig olvassuk el a Túlélni tervéből a címfelirat alatt háttérként szemcsésre felnagyított fotó leírását. Erdély a fotó bemutatásakor - a közelgő katasztrófa félárnyékában fiúk állnak fürdőnadrágban egymás mellett - nem szól magáról és a testvéreiről, de mi, éppen ilyen halkan ideilleszthetjük az 1940 körül róla és a fivéreiről készült fürdőnadrágos fotót: László, Ferenc, György, István és Miklós állnak egymás 
mellett a parton. [A fotót lásd: Erdély Dániel: „Mi kis” életünk. In: Árgus. 1991. szeptember-október, II. évf. 5. sz. 98. o.]

Erdély Miklós a sokáig hazavárt testvérek helyett 1973 októberében egy levelet kapott A Nácizmus Magyarországi Üldözötteinek Országos Érdekvédelmi Szervezetétől. A formanyomtatvány az 1957-es Jóvátételi Törvény, a Bundesrückerstattungsgesetz alapján a háborúban elpusztított testvéreiért felajánlott jóvátételről értesít, mely egészen pontosan 8.125 Ft. A katasztrófa harmincadik évfordulóján kapott „kedves ajándékot” Erdély 1974-ben egy Jubileumi vegyes linzer-dobozban két stampedli kíséretében továbbküldi Pécsre, a IV. Országos Kisplasztikai Biennáléra. Azt kéri a szervezőktől, hogy a pénzből vegyenek fütyülős barackpálinkát, majd a formanyomtatvány, a felespoharak és a vásárlásról szóló Közért-számla mellé helyezzék ki azt is, illetve kínálják fel a vendégeknek, hogy koccinthassanak az elhunytakra - avagy, tegyük hozzá, igyanak egyet a lelkiismeretük eltompítása végett. Az environment- és akcióterv címe Isten-Isten.

Az Isten-Isten nem emlékmü. Nem csak az elnémult sebeket vakarja fel, a koccintás nem csupán emlékezés a soában haltakra: a terv a kollektív szőnyeg alá söpréssel, a jóvátétel groteszk igyekezetével szembesít. A koccintás jól begyakorolt mozdulatát, az egymás szemébe nézést, a rutinból kimondott IstenIsten tautológiát, a kiállítótér oldott zsivaját fordítja át szemlesütésbe, zavartságba. A játék, a keserü nyelvi játék kérlelhetetlenül, mélyen markol bele az életbe. Az Isten-Isten választ kényszerít ki, ahogy ez meg is történt: a tervet elöbb az Országos Kisplasztikai Biennálé rendezői, majd az esseni Folkwang Museum is visszautasította - először 1991-ben, Székesfehérváron valósulhatott meg. Erdély jegyzeteiből idézek: „Aki nem iszik, vagy visszataszítónak találja az ügyet vagy annak kiállítását, nem hagyja felháborodását egy stampedli pálinkával elaltatni. Vajon mennyiért hajlandó nem haragudni? Hány hektoliter pálinka árát fogadná el engesztelésnek? [...] A pénzt fel kell venni, és az eljárás elleni demonstrációra kell fordítani, és ezáltal az adakozót és elfogadót arra inteni, hogy a jóvátehetetlent meg kell hagyni a maga abszolútumában [...].” [A munkáról lásd: Erdély Dániel: Mi kis családunk. In: Árgus. 1992. január-február, III. évf. 1. sz. 99. o.; Erdély Miklós /1928-1986/. Kiállítási katalógus, Csók István Képtár, István Király Múzeum, Székesfehérvár, 1991. október 26. - december 31. 28. o.; Az idézet forrása: György Péter: Erdély Miklós - A szelíd botrány müvésze. In: Holmi. 1992/8. sz. 1175. o. Az idézett rész némi módosítással szerepel még Erdély egy Maurer Dórához írt levelében is. A levelet lásd: Elhallgatott 
hogy Erdély életművének szinte az egészét végigkíséri az azonosságönazonosság problémája. Ahogy az Azonosításelméleti vizsgálatokban írja: „1. Ha ugyanolyat látok, azt gondolhatom, hogy ugyanazt látom. 2. Ha ugyanazt látom, azt gondolhatom, hogy mást látok, ami ugyanolyan.”250 A téziseket pedig az alkotóra vonatkoztatva feltárul a rá irányuló keresésünk hermeneutikai kimeríthetetlensége. ${ }^{251}$ A műveiben artikulálódó zsidó-nem

Holocaust - Sho'ah musteret - Bisterdo Holocaust - The hidden Holocaust. Kiállítási katalógus, Mücsarnok - Kunsthalle, Budapest, 2004. március 18. május 31. 158-159. o.]

Tíz évvel később, 1985-ben, a halála előtti évben megírja Aranyfasisztáim címü versét: „Most, hogy negyven év után első felháborodásomból | felocsúdtam, | most, hogy a természetes és mesterséges hullahegyek | mérete kiegyenlítődni látszik [...]” [Erdély Miklós: Aranyfasisztáim. In: MK. 20. o.]

${ }^{250}$ Erdély Miklós: Azonosításelméleti vizsgálatok. In: MK. 87. o.

${ }^{251}$ Erdély még legalább két munkáját tanulságos ideidéznünk. Az Idö-möbiuszban szerepelnek a következő tézisek: „3. Csak az képes magát alakítani, aki visszafordul és magára okként hat. 4. Aki magára okként hat, az már olyan, amilyenné magát alakítani kívánja. [...] 9. Ha annak tudatában élsz, hogy minden pillanatodhoz vissza(meg)térhetsz, saját megváltásodtól vagy bekerített. 10. Az ember tehát alávetett valakinek, aki a legjobban ismeri: önmagának. 11. Tarts önmagadtól. 12. Kész van, ami készül.” [Erdély Miklós: Idő-mőbiusz. In: MK. 95. o.] 1976-ban készítette el Időutazás című fotómontázs-sorozatát: az öt darabból álló sorozatban önmagáról és a családjáról 1922-ben - ekkor Erdély még meg sem született -, 1930-ban, 1934-ben, 1955-ben és 1961-ben készült képekbe másolta bele friss, erre a célra önmagáról készített fotóit. Az Időutazás 5. képén Erdély saját ifjúkori önmagának fülébe súg. [Az István Király Múzeum tulajdona. Először kiállítva: Najnowsza Sztuka Wegierska, Galeria Sztuki Najnowszej, Wrocław, 1976. április 20. - május 20. A montázselven, több negatív összemásolásával létrehozott kompozitképek fotótechnikai sajátosságáról lásd: Szilágyi Sándor: Neoavantgárd tendenciák a magyar fotómüvészetben 1965-1984. Fotókultúra - Új Mandátum Könyvkiadó, Budapest, 2007. 331. o. A fotósorozatról lásd még: Beke László: Avantgarde szekvenciák. In: Fotóművészet. 1977. XX. évf. 1. sz. 41. o.; Szabó Júlia: Emlékek a 70-es évekből. In: Müvészet. 
zsidó viszony dichotómiájában nem tudjuk őt elhelyezni. Az ö helye mindkettő és egyik sem. Az ő helye a mindig máshol, a kívül, a között. Ahogy később, 1980-ban megfogalmazza:

A macesz használatára azért vagyok alkalmas, mert speciális helyzetem van a zsidóság és a nem zsidóság között. [...] Tudniillik egy nem zsidó ember nem foglalkozhat a macesszal, nem hozhatja különböző helyzetekbe, tekintve, hogy ez a másik fél vallási érzékenységét sértené, talán brutálisnak is tartaná. [...] A zsidók pedig nem foglalkoznak a macesszal, mert náluk kegyeleti gátlás van: vallásfenntartó szimbólumuk. [...] [E]gy kicsit kívül kerültem ennek az örökrangadónak a drukkertáborain, emiatt nyugodtabb rálátásom van, és mind a két embercsoport közérzetét át tudom érezni. [...] Ugyanakkor azért kedvenc témám, mert tulajdonképpen ebben a problémakörben érzem

1980. október, XXI. évf. 10. sz. 10. o.; Hegyi Lóránd: Film/művészet. Kiállítás a magyar kísérleti film történetéről. In: Filmvilág. 1983. július, XXVI. évf. 7. sz. 13. o.; Kovalovszky Márta: Erdély Miklós: Időutazás. In: Fehérvári Müsor. 1988. V. évf. 2. sz. 13. o.; Antal István: Időutazás. In: Fotó. 1989. április, XXXVI. évf. 4. sz. 147-149. o.; Beszélgetéstöredék Erdély Miklóssal. In: Fotó. 1989. április, XXXVI. évf. 4. sz. 150-151. o.; Barna Róbert: Időutazás és vakablak. Interjútöredék Erdély Miklóssal és megjegyzések. (Az interjú 1976 nyarán készült.) In: Magyar Napló. 1992. szeptember 18. IV. évf. 19. sz. 35-36. o.; Szegő György: Fotó/szeánsz: Erdély Miklós. In: Magyar Mühely. 1999. XXXVII. évf. 110-111. sz. 142. o.; Szabó Júlia: Erdély Miklós: Időutazás, 1-5, 1976. (Székesfehérvár, István Király Múzeum). In: Magyar Mühely. 1999. XXXVII. évf. 110-111. sz. 146-149. o.; Forgács Éva: „... önmagát (oda-vissza) kölcsönösen meghatározza”. Időmetszetek, párhuzamos idősíkok az Időutazásban. In: Magyar Mühely. 1999. XXXVII. évf. 110-111. sz. 150-153. o. Újraközölt variáns: In: Uő: A Duna Los Angelesben. Müvészeti irások. Kijárat Kiadó, Budapest, 2006. 64-70. o.; Kicsiny Balázs: Óramotívum és eszkatológia. A mérhetö és a mérhetetlen ábrázolása. DLA értekezés, Magyar Képzőművészeti Egyetem, Doktori Iskola, Budapest, 2008. 54. o.] 
magam legjobban szellemileg, és jobb- vagy

baloldali elöítéletekre igen kényelmesen látok rá. ${ }^{252}$

Erdély Miklós említett két munkája végső soron azért zavarba ejtő, mert nem vállalja fel az egyik általa megidézett identitást sem. Hogy lehet az, hogy valaki zsidó és mégsem zsidó? Hogy lehet az, hogy valaki nem zsidó, és mégis az? Azonos az egyikkel is, a másikkal is, de leginkább egyikkel sem: helye a meghatározhatatlansággal, az önkioltással azonos.

Erdély jóval később, 1985-ben készítette el Zsidó, nem zsidó címü festményét. Az ezen lévő akáclevelek a gyermekkori 'szeret, nem szeret' játékot idézik: a levelek egyik sora „zsidó”, a másik „nem zsidó”. A betűk azonban nem a levelek ereiből rajzolódnak ki, és nem is a festmény anyagából - a feliratok máshogyan, test- és festményidegen technikával készültek: pecsételéssel. Az utolsó levél az egyetlen, amely nincs megpecsételve, amely azonosítatlan, s amely talán önazonos. ${ }^{253}$

${ }^{252}$ Erdély Miklós: Előadás a kiállításról. (Magnófelvétel után). (A kalcedoni zsinat emlékére címü environmentjéhez készült akciójának szövege, Bercsényi Kollégium, Budapest, 1980. március 18.) In: MI. 152-153. o. De lásd akár Erdély 1975-ben született Melyiket választod címü poémáját. [Erdély Miklós: Melyiket választod. In: $M K .50$. o.] És a köztes, nyitott helyzet egy másirányú továbbélése: Erdély a két fia közül az egyiket zsidónak, míg a másikat katolikusnak nevelte.

253 A gyermeki nyomhagyó játék felszabadultságát keverve a hivatalnoki, bürokratikus pecsételés egyetlen határozott mozdulattal mindent elintéző funkciójával Erdély 1983-ban mégiscsak megpecsételtette magát: „LÁTHATATLAN EMBER”-feliratú bélyegzőt nyomatott Galántai Györggyel a homlokára. A pecsétakció performatív aktusát, a jelenlétet és az önreflexiót paradoxonba tömörítve a pecsét jól láthatóan hitelesíti, jóváhagyja Erdély láthatatlanságát. (A pecsét két, egymással érintkező körbélyegzőből áll, az egyiken a „LÁTHATATLAN EMBER”, a másikon ennek tükörírása szerepel. A két érintkező kört vélhetjük a végtelen jelének, de egy Möbius-szalag egyszerüsített vetületi képének is, melyen, ahogy a mőbiusz-ra hurkolt filmszalagon, egyszer a képet, egyszer pedig annak fonákját látjuk.) [A 
festményhez, és ahhoz a zavarba ejtő identitás-kérdéshez, hogy „hogy lehet valaki zsidó és mégsem zsidó?”, lásd: Tillmann J. A.: „Nem hiszem, hogy még egy ilyen ember van a világon.” Erdély Miklós és A kalcedoni zsinat emlékére. In: Magyar Mühely. 1999. XXXVII. évf. 110-111. sz. 37. o.; Uő: Erdély Miklós és A kalcedoni zsinat. In: Uö: Merőleges elmozdulások. Utak a modern müvészetben. Új Palatinus-Könyvesház Kft., Budapest, 2004. 82. o. Interneten: http://www.c3.hu/ tillmann/irasok/muveszet/erdely.html; 2012. 11. 12. Ezúton is köszönöm Galántai György, Klaniczay Júlia és az Artpool Mủvészetkutató Központ segítségét és támogatását.] 


\section{Lezárás}

Erdély Miklós a Pop tanulmányban a klasszikus avantgárd hevületet mutatja fel: a kötöttségekből való kilépés és a kiállítótermek helyett a mindenkihez szólás szándékát, a müvészet társadalmi szerepvállalásának szükségességét. Számára a pop art ennek az eleven erőnek az egyik gyűjtőneve. A Pop tanulmányban írja a következőket: „A múzeumok rövidesen múzeumba kerülnek. A pop a jövőre vonatkozó izgalommal tüzetesen figyeli a jelent. [...] Nem lehetetlen, hogy a közeljövő legelterjedtebb művészete a tüntetés lesz.”254 S a pop artból, megkockáztathatjuk, számára talán inkább ez a fontos, semmint módszerei, anyaghasználata, technikái, formai, motivikus megoldásai vagy a reprezentáció-felfogása.

${ }^{254}$ Erdély Miklós: Pop tanulmány. In: MI. 33-34. o. Erdély a tőle megszokott módon a pop art kapcsán is meglehetősen erös írónak bizonyul. A pop art sajátosságainak izzó bemutatása mellett, mintegy azok közé kihelyezve, hozzájuk interpretálva megtalálhatjuk montázs-elméletének egy variánsát is: „[...] [M]indannyian ismerjük azt a hangulati, indulati, informatív törmelékhegyet, amit egy tv-müsor végignézése maga után hagy, s amivel megterhelve, kábán aludni térünk. Pop lelkesedik a televízióért. Kedvenc eljárása, hogy mint enyhe agyérelmeszesedésben szenvedő tv-tulajdonos hűségesen végigszunyókálja a müsort, egy gépfegyversorozatra vagy egy gyerekkórus túl éles hangjára időnként felijed; hagyja, hogy létrejöjjön benne a benyomások természetes montázsa, képhibákkal együtt.” [Uo. 26. o.] Erdély szabadság-teóriáját pedig mind a pop arttal, mind a gesztusfestészettel összecsendíti: „Pollock úgy gondolta, jó az a négyzet, csak kicsi. Hatalmas csomagolópapírokat terített le tehát nekikeseredetten, kannából locsolta rá a festéket. Szabadnak érezte magát - az a remény fütötte; ami szabad, elkerülhetetlenül szép is. És még az: a szépség nem lehet korlátja, hanem jele a szabadságnak.” [Uo. 36. o.] 
Erdély Miklós Pop tanulmánya fontos szövegszerü bizonyítéka annak, hogy a magyarországi neoavantgárd egyik meghatározó forrása a pop art. Viszont lehetetlen volt néhány egy irányba tartó mondattal válaszolnunk azokra a kérdésekre, hogy Erdély miként kötődik a pop arthoz és a politikumhoz. ${ }^{255}$ Ha mégis tömörebben szeretnénk válaszolni, kiegészítések között kell egyensúlyoznunk:

Az egyik pontosítás, hogy a Pop tanulmányban habár hosszasan ír Erdély a pop artnak a formákhoz, a divathoz való viszonyáról, pop artos megoldásokkal nála mégis csupán fotómozaik-találmánya kapcsán találkozhatunk: az állami tervezőirodákban vállalt munkáját részben felfüggesztve 1963-ban vágóasszisztensként kezdett dolgozni a Magyar Televíziónál, majd az 1966-ban kiötlött mozaik-eljárására alapozva épületdíszítő, tartósreklám-kivitelező mühelyt nyitott. ${ }^{256}$ A technika

255 „E. M.: Rendszerint nem erről van szó, hogy megválaszolhatatlan a kérdés. A válasz mellébeszélés. Ezt úgy is lehet értelmezni, hogy megválaszolhatatlan a kérdés, de úgy is, hogy a mellébeszélés nyesi a kérdést, forgatónyomatékot ad neki, s mikor a kérdés forog, az már válasz is rá.” [Sebők Zoltán: Új misztika felé - Beszélgetés Erdély Miklóssal. In: Híd. 1982/3. sz. 371. o.] „[...] [I]tt kimondta a gazda, amit eredetileg is akart vóna, de hogy ne legyen nagyobb perpatvar, mindjárt a nyakába is borult a fiúnak, zokogott, mint a szivárvány, az a rémült fekete fiú elment tőle, nagy kazal szőkét vágott, bemutatta a Földmüvelésügyi Minisztériumban, ahol megdicsérték, mivelhogy nem akármilyen, hanem tisztességes munkát végzett. Meg is dicsérték annak rendje-módja szerint.” [Erdély Miklós: Arabeszk. In: MK. 69. o.]

${ }^{256}$ Erdély 1946-47-ben a Magyar Képzőművészeti Főiskolára járt, ahol Kisfaludy Stróbl Zsigmondnál, magánúton pedig a mesterének tekintett Bokros Birman Dezsőnél folytatott szobrászati tanulmányokat. 1947-ben felvették a Budapesti Műszaki Egyetemre, ahol 1951-ben építészmérnöki diplomát szerzett. Ezt követően, 1951-1963-ig különböző építőipari vállalatoknál dolgozott: Gépipari Beruházási Vállalat, 41. sz. Állami Építőipari Vállalat, Qualitas, AGROTERV, BUVÁTI, KÖZTI, BÉPA. Több terve megvalósulhatott, néhányat kiállítottak, s 
egy-egy szakmai írása is megjelent. Mủemléki helyreállításokban vett részt többek közt a budai Vár rekonstrukciójában: a kupolán lévő tü és kilátókosár Erdély munkája -, kidolgozott egy forradalmi tetraéder-oktaéder szerkezetet, a Qualitas vállalatnál pedig édesapjával, a szintén építész Erdély Istvánnal közösen saját héjfalazó-technikájukat is kipróbálták. A diplomaszerzés után emellett rendszeresen énekelt, operaénekesnek készült a Magyar Állami Operaházba. Az '50-es évek közepén születtek első versei, majd a '60-as évektől folyamatosan alakultak, érlelődtek szépirodalmi (bármit is jelentsen ez) erényeket sem mellőző elméleti írásai, tanulmányai, esszéi. 1959-ben és 1963-ban is felvételizett a Színház- és Filmművészeti Főiskola filmrendező szakára, azonban mindkét alkalommal, még a tanévkezdés előtt eltávolították. Ekkor polgári szakmáját részben feladva vágóasszisztensként kezdett dolgozni a Magyar Televíziónál. 1966-ra fejlesztette ki, majd az 1967-es BNV-n mutatta be fotómozaik-eljárását, mely némi függetlenséget is biztosított számára. Előbb a BÉPA (Budapesti Építőanyagipari Ktsz) keretein belül, majd Murus néven saját mühelyt nyitott, ahol többek között fotómozaik tervezésével és kivitelezésével foglalkoztak. A kompozíciókat többnyire Erdély tervezte, de itt tudott tervezői munkát adni Raffay Bélának, Lakner Lászlónak, Altorjai Sándornak, Pauer Gyulának, Korényi Dalmának, Rajczy Margitnak, Veres Gizellának, Szabó Ákosnak, Hencze Tamásnak és Erdély Dánielnek is. A leválogatás, árnyalatkeresés hosszú munkáját pedig a tervezökön kívül még jó néhányan segítették, tapasztalatot, közösséget, némi anyagi segítséget és - ami legalább úgy fontos volt - munkakönyves állást kapva.

Persze feltehetjük a kérdést, hogy: végül is mivel foglalkozott Erdély Miklós? Ám erre sem adhatunk egyszerü választ. Citálhatjuk Erdély szavait, de akár felidézhetünk egyet a Száz chászid történet közül is. A legfontosabb így szól: „Nemsokkal a kobrini rabbi Móse halála után egyik tanítványától azt kérdezte az »öreg Kocki« rabbi Mendel: »Mi volt mestered számára a legfontosabb?« A tanítvány kissé elgondolkodott, aztán szólt: »Mindig az, amivel éppen foglalatoskodott.«” [Martin Buber: Száz chászid történet. Ford. Pfeiffer Izsák. Magyar Zsidók Pro Palesztina Szövetsége, Budapest, 1944. 70-71. o.] Ahogy pedig Erdély 1982-ben Sebők Zoltánnal beszélgetve fogalmaz: „Rájöttem, hogy azért foglalkozom ilyen sok mindennel, hogy ne forgácsoljam szét magam. Ha az ember valamire kijegyzi magát, kénytelen rengeteg képességét leforgácsolni.” [Sebők Zoltán: Új misztika felé - Beszélgetés Erdély Miklóssal. In: Híd. 1982/3. sz. 373. o.] És ahogy már 1964 körül írja: „Semmi örömöm nem volt soha, ha 
lényege: felnagyított fotók vagy különböző képekből összeálló montázsok rasztereit fedték le Szentendrén gyártott kerámiamozaikkal, melyeket így nagy felületre tudtak felhelyezni. Készült ezzel a technikával portré Bartók Béláról, Brigitte Bardot-ról, Salvador Dalìról, de Fabulon- és OTP-reklám is, valamint még ma is láthatóak ilyen képek többek között a Dagály gyógyfürdőben, a nyíregyházi uszodában - ezen Erdély ikertestvérei állnak a szivárvány alatt, fürdőnadrágban -, a hajdúszoboszlói gyógyfürdőben és Miskolcon az Eszem-iszom, valamint a Bor-Is vendéglátóipari-egységek falain. Ezeknek a képeknek a részleteit nem erőteljes kontúrok, nem határozott vonalvezetés, hanem a csak közelröl kivehető, egymástól finom árnyalatnyi eltérésekkel összeválogatott mázas mozaikszemek, illetve a mozaikszemek közötti rések választják el egymástól. Közelről a raszter feszes rendjét látjuk, ami távolabbról hiperrealista-popos képekké áll össze. Az életműben esetleg itt találhatunk pop artos munkákat tőle. ${ }^{257}$

csak azt nem számítom, hogy egy falon húzódó repedést időnként iszappal töltöttem be, és míg az ki nem száradt és ki nem pergett, elvégzett munkám némi elégedettséggel töltött el, mikor kihullott, bosszankodtam. Bizonyos idő eltelte után bosszankodásomat némi öröm váltotta fel, mert elöre örültem annak az elégedettségnek, ami tapasztási munkámat követte, így izgatott álbosszankodással vártam, hogy az iszap kiperegjen. Mikor felfedeztem, hogy ilyen módon elviselhetőbb az életmódom, sok egyéb hiábavaló tevékenységet kerestem magamnak.” [Erdély Miklós: Parton. In: MK. 23. o.]

${ }^{257}$ Perneczky Géza már 1970-ben üdvözli az eljárást, mellyel szerinte új műfaj, a fotómozaik müfaja született meg Magyarországon: „A világot ma többnyire úgy látjuk, ahogy fényképezzük, vagy ahogy filmre vesszük. Ezt a tekintetet átmenteni a díszítőmủvészet és az ábrázolás számára, anélkül, hogy banalitásokba csúsznánk: nagy eredmény.” [Perneczky Géza: Műfaji kérdések. In: Élet és Irodalom. 1970. március 7. XIV. évf. 10. sz. 12. o. Lásd még: Perneczky Géza: Új müfaj: A fotómozaik. In: Tükör. 1970. november 3. 44. sz. 30. o.; Perneczky Géza: A fotómozaikról. Kézirat, Artpool, é.n.; Heitler László: Müteremlátogatás Hencze Tamásnál. In: Életünk. 1971. november-december, II. évf. 6. sz. 567-571. 
A másik lényegi kiegészítés, hogy habár Erdély üdvözli a tüntető hevületet, az ő munkáiban mégsem érhetünk tetten radikális provokációt. Amíg Szentjóby Tamás ekkori munkái akár egészen konkrétan reagálnak aktuális nemzetközi eseményekre, addig Erdély alkotásai finomabb célzásokkal élnek. Erdélynél inkább szelíd, ironikus, groteszk utalásokkal találkozhatunk. Ilyen az 1972-ben készült Két személy, aki döntő befolyással volt a sorsomra címü fotómunkája is. ${ }^{258}$ Egy fektetett A/4-es

o.; Somogyi György: Elektronikus mozaikok. In: Müvészet. 1981/5. sz. 47-48. o.; Erdély Dániel: Mi kis családunk. In: Árgus. 1992. január-február, III. évf. 1. sz. 97-98. o.; Erdély Dániel: „Mi kis” életünk. In: Árgus. 1992. március-április, III. évf. 2. sz. 60-61. o., 68. o.; Somogyi Győző: Hármas kép Erdély Miklósról. In: Új Müvészet. 1992. III. évf. 4. sz. 14-15. o.; Keserü Katalin: Variációk a pop artra. Fejezetek a magyar müvészetből 1950-1990. Új Mủvészet Kiadó, é.n. 27. o.; Performance-os esték és Pataki Ági rejtélye. In: MaNcs. 2000. február 24. XII. évf. 8. sz. 45. o.; Erdély Miklós mozaikja úton a megmenekülés felé. In: Népszava. 2000. július 5. CXXVIII. évf. 155. sz. 11. o.; Bóka B. László: Kié lehet Erdély Miklós híres mozaikja? In: Népszava. 2000. augusztus 29. CXXVIII. évf. 202. sz. 12. o.; „Az utókor kiszámíthatatlan”. Lakner László képzőművésszel Topor Tünde készített interjút. In: Élet és Irodalom. 2001. szeptember 21. XLV. évf. 38. sz. 11-12. o.; Bóka B. László: Érdektelen a Fabulon-mozaik? In: Népszava. 2001. november 10. CXXIX. évf. 262. sz. 10. o.; Erdély Dániel: Tárgytörténet. In: Ponticulus Hungaricus. 2005. október, IX. évf. 10. sz. Interneten:

http://members.iif.hu/visontay/ponticulus/rovatok/hidverok/spidron1.html. 2013. 03. 10.; Müllner András: Fotómozaikokról mozaikosan. In: Müút. 2008/008. sz. 56-59. o.; Boros Géza: Leletmentés. Erdély Miklós fotómozaikjai. In: Artmagazin. 2014. XII. évf. 6. sz. 70. sz. 28-36. o.; Boros Géza: Szúkített spektrumok. Erdély, Hencze, Jovánovics. In: Müértő. 2014. szeptember, XVII. évf. 9. sz. 8. o.]

${ }^{258}$ Egy svájci lapban való megjelenése után - ironizálás ide vagy oda - Beke László elmesélése szerint Erdély felesége, Szenes Zsuzsa az állami Iparmúvészeti Vállalattól egy jó ideig nem kapott munkát. [Beke László - Urs Graf: Junge Kunst in Ungarn. In: Werk. 1972/10. 59. Jahrgang, No. 10. 592-598. o.; Bihari László: 
lap tetején a cím szerepel, s alatta egyszerüen egymás mellé helyezve két portrét látunk: az egyik Kádár Jánosé - egy transzparensen lefotózva -, a másik pedig Erdély Miklós feleségét, Szenes Zsuzsát ábrázolja. ${ }^{259}$ Müvészetében az irónia groteszkbe átfordulásának pedig frappáns, fanyar és tömör példája az 1974-ben megjelent Kitüntetéseimről című írása: „Születésemnél fogva alkalmas vagyok a kitüntetésre. Ugyanis a bal mellkasom jó egyharmaddal nagyobb, ha ugyan nem másfélszerese a jobboldalinak. E ritka rendellenesség következtében széles felületet kínálok

Kiveszőben lévő mentalitás. (Beszélgetés Beke Lászlóval és Peternák Miklóssal). In: Magyar Hírlap. Ahogy tetszik. A Magyar Hírlap kulturális magazinja. 1998. október 3. XXXI. évf. 232. sz. 13. o.; Beke László: A magyar konceptuális müvészet szubjektív története. In: Né/ma? Tanulmányok a magyar neoavantgárd köréből. Szerk. Deréky Pál és Müllner András. Ráció Kiadó, Budapest, 2004. 236. o.] Erdélynek ezt a munkáját Beke ugyancsak említi a Vakáció. A balatonboglári kápolnatárlatok története címü 1998-as dokumentumfilmben. [Vakáció. A balatonboglári kápolnatárlatok története, 1970-1973. Szakértő-riporter: Sasvári Edit. Szerkesztő: Római Róbert. Operatőr: Gombos Tamás. Rendező: Soós Árpád. MTV, V. Stúdió, Fríz Produceri Iroda, 1998.] A dokumentumfilmben elhangzó interjú(k)ból pedig terjedelmes, reprezentatív anyag olvasható a Törvénytelen avantgárd címü kötetben. [Visszaemlékezések. In: Törvénytelen avantgárd. Galántai György balatonboglári kápolnamüterme 1970-1973. Szerk. Klaniczay Júlia és Sasvári Edit. Artpool-Balassi, Budapest, 2003. 191-210. o.]

${ }^{259}$ A reprezentáció duplikációjának rétegzettsége, a tüntetőtábla, avagy május 1-ei felvonulási tábla nélkül, de hasonló formai megoldást használ Erdély egy 1980-as, az Akvarell címü tárlaton kiállított munkájában is. Ennek a politikai felhangjait már talán csak csendben lehet kihallani, viszont a mủ így annál inkább nyitott a különbözőség/hasonlóság és a távolság/közelség általános problémájára. A címe: Böröcz András nem hasonlít Franz Kafkára. A papíron Böröcz és Kafka egymáshoz hasonló beállítású, hasonló kivágatú fotói vannak egymás mellé ragasztva, melyeken a két személy kicsit eltérő felöltőt és kicsit eltérő kalapot visel. Alatta vonalak közé rajzolt felirat hirdeti: „Böröcz Andris nem hasonlít Franz Kafkára, mint ahogy az akkori viszonyok nem hasonlítanak a jelenlegiekre.” 
az érdemrendek számára, s talán ennek köszönhetem, hogy feljebbvalóim néhány találkozás után, többnyire mondvacsinált érdemek alapján, kitüntetésemre szánják el magukat. Így gyakran néztem feljebbvalóim szemébe és álltam acélos tekintetüket, melyből csak úgy áradt a meggyőződés, hogy ez esetben valóban »rátermett « egyént ér a megtiszteltetés.”260 De ezekkel a munkáival már a ’60-as éveket elhagyva a ’70-es évek elején járunk.

Disszertációm Erdély Miklós életmüvének főként két szakaszára koncentrált. Egyfelől az 1960-as évek második felére, azaz a neoavantgárd címszóval egybefogott törekvések kezdetére, mikor is Erdély a színrelépése első momentumaival már rögtön egy erös, érett, eredeti és szokatlan szemléletet vitt a magyar müvészeti életbe. Dolgozatom másik fókuszpontja Erdély Miklós 1980-as évekbeli gondolatai és alkotásai voltak. Az az időszak, amely egy kivételesen sürü alkotói periódust jelent életmüvében s egyszersmind a '60-as évek derekától formálódó teóriája kiteljesedését. Disszertációm nem kronologikus sorrendben közelítette meg a két periódust. Előbb Erdély '80-as évekre kikristályosodott teóriáját mutatta be a Marly téziseken keresztül, hogy innen nyisson rálátást tárgyiasult gondolataira, s így, már a konkrét alkotásokra fókuszálva illessze be törekvéseit az avantgárd sokszínű mozgalmasságába.

Másként összegezve dolgozatomat: Erdély Miklós a műalkotáshoz társítja az üresség, a szépség és a szabadság kategóriáját, s disszertációm e három kategóriát követte végig. Bemutatva mindeközben azt, hogy az időszak központi alakjának sajátságos törekvései miként viszonyulnak a periódus meghatározóvá váló művészeti tendenciájához, a konceptuális mủvészethez, illetve a neoavantgárd egyik meghatározó forrásához, a pop

${ }^{260}$ Erdély Miklós: Kitüntetéseimröl. In: KO. 44. o. 
arthoz. Dolgozatom a teóriától indulva haladt a tárgyiasult gondolatok, valamint a müalkotásokat körülvevő müvészeti, társadalmi kontextus, a közvetlen élet irányába. A szabadság kategóriájához és a pop arthoz érve az utolsó nagyobb egységben arra a kérdésre kerestem a választ, hogy a szabadság Erdély-féle teóriája milyen viszonyban áll korának politikai berendezkedésével. Azaz arra a kérdésre, hogy ha számára a szabadság elsőszámú letéteményese a müvészet, akkor pontosabban milyen a művészetének az őt körülvevő politikumhoz, a szabadság aktuális lehetőségeihez való viszonya. Válaszolni pedig erre csak úgy volt lehetséges, hogy figyelembe vettük alkotásainak kontextusát: politikumhoz füződő sajátságos viszonyát úgy érthettük meg árnyaltabban, hogy nem csupán az ő alkotásait vettük sorra, hanem beillesztettük azokat az egykorú müvészet, valamint honi és nemzetközi történések közegébe is. Ebben az egységben azt mutattam be, hogy a '60-as évek második felének avantgárd művészetéhez mérten Erdély Miklós alkotásai közel sem súlytalanok, azonban mégis szelíd állapotot tükröznek.

Az eddigiek alapján összességében azt mondhatjuk, hogy Erdély Miklós ebben a periódusban üdvözli a művészet konfrontációt sem kerülő társadalmi szerepvállalását, ugyanakkor müvészi megnyilatkozásaiban többnyire az aktuális politikán kívül áll: munkái a politizálásnak elvontabb, általánosabb és szelídebb szintjén mozognak. S hogy Erdély munkái pontosan még mihez képest is szelídebbek? Ennek megvilágítására legalább még néhány példát érdemes lenne felidéznünk arról, miként fonódott össze a politikai provokáció és protestálás a magyarországi neoavantgárddal. Teljességre természetesen nem törekedhetünk, azonban ha legalább még néhány alkotót említeni szeretnénk, azt már csak egy következő írásban tehetjük meg. Az 1970-es éveket szemlélve pedig mindenképpen meg kell 
majd állnunk a Galántai György által életre hívott balatonboglári kápolnatárlatok sűrü, kivételes, ámde rövid három nyaránál is. A balatonboglári kápolnánál mint a magyarországi neoavantgárd azon kitüntetett helyszínénél, ahol három éven át tudtak összegyülni az indexre tett, többségében a türt és a tiltott kategóriába tartozó progresszív mủvészek: olyanok, akik a támogatott müvészeti életből kiszorultak, avagy abból inkább nem is kértek.

Így ezt az írást azokkal az ígéretekkel tudom befejezni, amelyekkel Erdély Miklós a Metán című versét indítja. Tehát:

- A leglényegesebb körülményekre majd máskor térek ki, ha egyáltalán kitérek.

- A leütött alaphang a továbbiakban változni nem fog, ez azonban semmiféle büszkeséggel nem tölt el. ${ }^{261}$

${ }^{261}$ Erdély Miklós: Metán. In: MK. 7. o. 


\section{Felhasznált irodalom}

Aknai Katalin - Merhán Orsolya: Belső zsüri. A Fiatal Képzőművészek Stúdiójának története 1958-1978. In: A második nyilvánosság - XX. századi magyar müvészet. Összeállította Hans Knoll. Enciklopédia Kiadó, Budapest, 2002. 200-227. o.

Almási Miklós: Anti-esztétika - Séták a müvészetfilozófiák labirintusában. Helikon Kiadó, Budapest, 2003.

Altorjay Gábor: Az ebéd (In memoriam Batu kán), 1966. június 25. In: A magyar neoavantgárd elsö generációja 1965-72. Kiállítási katalógus, Szombathelyi Képtár, Szombathely, 1998.

Altorjay Gábor: Élet, anyag, happening. In: Magyar Mühely. 2004. 228129. sz. 15-16. o. Újraközölve: Altorjay Gábor: Élet, anyag, happening. In: Az ebéd (In memoriam Batu kán). HAPPENING Budapest $H$ 1966. The Lunch (In Memoriam Batu Khan). Szerk. László Zsuzsa, St. Turba Tamás. Ford. Polonyi Csaba. Tranzit Hungary Közhasznú Egyesület, Budapest, 2011. 15. o., 50. o.

András Sándor: Koncept? Ötlet? Hol és kinek? Koncept koncepció, szemelvények. In: Balkon. 2008/6. sz. 6-9. o.

Andrási Gábor: A gondolat formái. In: Nappali ház. 1993/2. sz. 70-77. o. Újraközölve: A gondolat formái. »Érzéki konceptualitás « a kortárs magyar képzőmüvészetben. In: A modern poszt-jai. Esszék, tanulmányok, dokumentumok a 80-as évek magyar képzömüvészetéröl. Szerk. Keserü Katalin. ELTE, Bölcsészettudományi Kar, Budapest, 1994. 75-87. o.

Andrási Gábor, Pataki Gábor, Szücs György, Zwickl András: Magyar képzömüvészet a 20. században. Corvina, Gyula, 1999.

Antal István: Időutazás. In: Fotó. 1989. április, XXXVI. évf. 4. sz. 147149. 0 .

Arday Lajos: Reformok és kudarcok. Jugoszlávia utolsó évtizedei és ami utána következett. Books in Print, Budapest, 2002.

Arisztotelész: Ethica Nicomachea. 1155b 4. In: Görög gondolkodók 1. Ford. Kerényi Károly. Kossuth Könyvkiadó, Budapest, 1993. 32. o.

Arje Palgi (Fleischmann László): Aczél György és a zsidóság. In: Szombat. 1990. augsztus, I. évf. 6. sz. 13-14. o.

Asztalos, Cs. Anik [Körner Éva]: No isms in Hungary. In: Studio International. 1974. March, Vol. 187. No. 964. 105-111. o. 
Atkinson, Terry: Concerning the Article »The Dematerialization of Art . In: Conceptual Art: A Critical Anthology. Ed. Alexander Alberro, Blake Stimson. The MIT Press, Cambridge, Massachusetts, London, England, 1999. 52-58. o.

$\mathrm{Az}$ Emberi Jogok Egyetemes Nyilatkozata. Interneten: http://www.ohchr.org/EN/UDHR/Pages/Language.aspx?LangID=hng; 2013. 07. 28.

Az Országos Béketanács és az Indigo csoport Nemzetközi Képzőmüvészeti Pályázatot hirdet a nukleáris veszélyeztetettség tárgyában. In: KREATIVITÁSI GYAKORLATOK, FAFEJ, INDIGO - Erdély Miklós müvészetpedagógiai tevékenysége 1975-1986. Összeállította Hornyik Sándor, Szőke Annamária. MTA Művészettörténeti Kutatóintézet Gondolat Kiadó - 2B Alapítvány - Erdély Miklós Alapítvány, Budapest, 2008. 384-385. o.

Az utcán. In: Magyar Világ. 1956. november 3. I. évf. 3. sz.

„Az utókor kiszámíthatatlan”. Lakner László képzőművésszel Topor Tünde készített interjút. In: Élet és Irodalom. 2001. szeptember 21. XLV. évf. 38. sz. 11-12. o.

Ágh István: Föl-le a Ménesi úton. In: Magyar Nemzet. 1989. január 21. LII. évf. 18. sz. 11. 0.

Ágh István: Kidöntött fáink suttogása. Nap Kiadó, Budapest, 2008.

Ágh István: Kondor-memoár. In: Magyar Nemzet. 1989. február 25. LII. évf. 48. sz. 11. o.

Ágh István: Szigliget-memoár. In: Magyar Nemzet. 1988. április 30. LI. évf. 102. sz. 11. o.

Ágh István: Virágárok. Kortárs Kiadó, Budapest, 1996.

Ágh István: Virágárok. In: Magyar Nemzet. 1989. május 6. LII. évf. 104. sz. 11. 0 .

Babarczy Eszter: Határátlépő. Erdély Miklós. (értelmezési kísérlet). In: Új Müvészet. 1992. április, III. éfv. 4. sz. 4-13. o.

Balassa Péter: Erdély Miklós mint írás. In: Magyar Mühely. 1999. XXXVII. évf. 110-111. sz. 44-48. o.

Balassa Péter: Erdély Miklós mint predekonstruktivista. In: Kritika. 1999/1. sz. 35-36. o.

Bardi Teri: A senki földjén voltunk... Beszélgetés Sugár Jánossal. In: Beszélö. A senki földjén. A Beszélö melléklete Erdély Miklósról. 1991. október 26. Új folyam II. évf. 43. sz. 8-10. o.

Barna Róbert: Időutazás és vakablak. Interjú-töredék Erdély Miklóssal és megjegyzések. (Az interjú 1976 nyarán készült.) In: Magyar Napló. 1992. szeptember 18. IV. évf. 19. sz. 35-36. o. 
Bartholy Eszter: Erdély Miklós: Bújtatott zöld. In: Magyar Mühely. 1983. július, XXI. évf. 67. sz. 64-66. o.

Beke László: A magyar konceptuális mủvészet szubjektív története. In: Né/ma? Tanulmányok a magyar neoavantgárd köréböl. Szerk. Deréky Pál és Müllner András. Ráció Kiadó, Budapest, 2004. 227-239. 0.

Beke László: A müvészet embertelensége (fikcióesszé). In: Beke László: MÜVÉSZET/ELMÉLET - Tanulmányok 1970-1991. Balassi Kiadó BAE Tartóshullám - Intermedia, Budapest, 1994. 172. o. 169-181. o.

Beke László: Avantgarde szekvenciák. In: Fotómüvészet. 1977. XX. évf. 1. sz. 37-41. 0 .

Beke László: Az emberi test és a médiumok - képzőművészet és színház között. In: Beke László: MÉDIUM/ELMÉLET - Tanulmányok 1972_ 1992. Balassi Kiadó - BAE Tartóshullám - Intermedia, Budapest, 1997. 142-162. o.

Beke László: Dátumok a magyar avantgarde-müvészet történetéből, 19661979. In: Müvészet. 1980. október, XXI. évf. 10. sz. 20-22. o.

Beke László: Elektromosság és müvészet Magyarországon. In: Beke László: MÉDIUM/ELMÉLET. Tanulmányok 1972-1992. Balassi Kiadó - BAE Tartóshullám - Intermédia, Budapest, 1997. 231-241. o.

Beke László: Erdély Miklós. In: Híd. 1982/3. sz. 377-391. o.

Beke László: Erdély Miklós és a müvészettörténet. Az MKE Intermédia Tanszékén az Erdély Miklós Alapítvány által szervezett Erdély 80|80 címü szemináriumon elhangzott előadás. (2008. június 6.) Interneten: http://catalog.c3.hu/index.php?page=work\&id=49\&lang=HU; 2013. 04.05.

Beke László: Erdély Miklós munkássága. Krono-logikai vázlat képekkel 1985-ig. In: Erdély Miklós. Kiállítási katalógus, Óbuda Galéria, Zichy Kastély, 1986. április 11. - május 5. 2-29. 0.

Beke László: Erdély Miklós: Kollapszus Orv. In: Életünk. 1986. augusztus, XXIII. évf. 8. sz. 749-750. o.

Beke László: Fotó/müvészet. In: Expozíció. Fotó/müvészet. Kiállítási katalógus, Hatvany Lajos Múzeum, Hatvan, 1976. október 24. - 1977. január 31. A Hatvany Lajos Múzeum Füzetei No 2., MÉM STAGEK sokszorosító 367/76. o.n.

Beke László: Fotó-látás, fotóhasználat az új magyar mủvészetben. In: Beke László: MÉDIUM/ELMÉLET. Tanulmányok 1972-1992. Balassi Kiadó - BAE Tartóshullám - Intermédia, Budapest, 1997. 17-28. o.

Beke László: Görényi Frigyes: Marcel Duchamp. In: VISZONTLÁTÁSRA! DUCHAMP. Készült a VISZONTLÁTÁSRA! • Marcel Duchamp magyarországi hatásai c. kiállításhoz, Budapest Galéria Kiállítóháza, 
1996. november 14. - december 8. Budapest Galéria, Budapest, 1996-2000. 42-44. o.

Beke László: KENTAUR. In: Magyar Mühely. 1978. június, XVI. évf. 5455. sz. 66-91. o. Újraközölve: In: Mozgó Film 2. A BBS Mühelykiadványa. Szerk. Forgács Péter. A „K” rovatot szerkesztette: Beke László. Balázs Béla Stúdió, Budapest, 1986. 199-240. o.

Beke László: Képzőművészet 2000-ben? In: Beke László: MÜVÉSZET/ELMÉLET - Tanulmányok 1970-1991. Balassi Kiadó BAE Tartóshullám - Intermedia, Budapest, 1994. 56-68. o.

Beke László: Klaus Groh könyvéről és néhány általános problémáról. In: Magyar Mühely. 1974. április, XII. évf. 43-44. sz. 40-48. o.

Beke László: Konceptuális mủvek és szöveghasználat, fotó, film, videó az 1970-es években. In: Pauer. Összeállította Szőke Annamária. Szerkesztette Szőke Annamária és Beke László. MTA Művészettörténeti Kutatóintézet, Budapest, 2005. 63-66. o.

Beke László: Kontextuális művészet. In: Beke László: MÜVÉSZET/ELMÉLET - Tanulmányok 1970-1991. Balassi Kiadó BAE Tartóshullám - Intermedia, Budapest, 1994. 152-154. o.

Beke László: Miért használ fotókat az A.P.L.C.? In: Beke László: MÉDIUM/ELMÉLET Tanulmányok 1972-1992. Balassi Kiadó - BAE Tartóshullám - Intermedia, Budapest, 1997. 7-16. o.

Beke László: Milyen ne legyen a Hrabal-darab színpadképe? In: Mozgó Világ. 1982/7. sz. 59-69. o.

Beke László: Müfajok és médiumok. In: Beke László: MÉDIUM/ELMÉLET - Tanulmányok 1972-1992. Balassi Kiadó - BAE Tartóshullám Intermedia, Budapest, 1997. 102-119. o.

Beke László: The work of Miklós Erdély, a chrono-logical sketch with pictures up to 1985’. In: Miklós Erdély. Kiállítási katalógus, Szerk. Szőke Annamária. Georg Kargl Fine Arts, Wien - Kisterem, Budapest - tranzit.hu, Budapest - Miklós Erdély Foundation, Budapest, 2008. 5-47. 0.

Beke László: Türni, tiltani, támogatni - A hetvenes évek avantgárdja. In: A második nyilvánosság - XX. századi magyar müvészet. Összeállította Hans Knoll. Enciklopédia Kiadó, Budapest, 2002. 228-247. 0.

Beke László: Újabb avantgarde irányzatok. In: Beke László: MÜVÉSZET/ELMÉLET - Tanulmányok 1970-1991. Balassi Kiadó BAE Tartóshullám - Intermedia, Budapest, 1994. 119-126. o.

Beke László - Peternák Miklós: Beszélgetés Erdély Miklós írásairól. In: Jelenkor. 1987. november, XXX. évf. 11. sz. 999-1003. o.

Beke László - Peternák Miklós: Szerkesztői megjegyzések. In: Erdély Miklós: Második kötet. Vál., szerk. Beke László, Peternák Miklós és a 
Magyar Mühely szerkesztősége. Magyar Mühely, Párizs, Bécs, Budapest, 1991. 103-107. o.

Beke László - Urs Graf: Junge Kunst in Ungarn. In: Werk. 1972/10. 59. Jahrgang, No. 10. 592-598. o.

Beszélgetés Beke Lászlóval. In: Hatvanas évek. Új törekvések a magyar képzömüvészetben. Kiállítási katalógus, Magyar Nemzeti Galéria, 1991. március 14. - június 30. Összeáll. Beke László, Dévényi István, Horváth György. Szerk. Nagy Ildikó. Képzőmüvészeti Kiadó Magyar Nemzeti Galéria - Ludwig Múzeum, Budapest, 1991. 193197. o.

Beszélgetés Csáji Attilával In: Hatvanas évek. Új törekvések a magyar képzőmüvészetben. Kiállítási katalógus, Magyar Nemzeti Galéria, 1991. március 14. - június 30. Összeáll. Beke László, Dévényi István, Horváth György. Szerk. Nagy Ildikó. Képzőművészeti Kiadó Magyar Nemzeti Galéria - Ludwig Múzeum, Budapest, 1991. 185191. o.

Beszélgetés Fajó Jánossal. In: Hatvanas évek. Új törekvések a magyar képzömüvészetben. Kiállítási katalógus, Magyar Nemzeti Galéria, 1991. március 14. - június 30. Összeáll. Beke László, Dévényi István, Horváth György. Szerk. Nagy Ildikó. Képzőművészeti Kiadó Magyar Nemzeti Galéria - Ludwig Múzeum, Budapest, 1991. 169174. 0 .

Beszélgetés Keserü Ilonával. In: Hatvanas évek. Új törekvések a magyar képzömüvészetben. Kiállítási katalógus, Magyar Nemzeti Galéria, 1991. március 14. - június 30. Összeáll. Beke László, Dévényi István, Horváth György. Szerk. Nagy Ildikó. Képzőmüvészeti Kiadó Magyar Nemzeti Galéria - Ludwig Múzeum, Budapest, 1991. 139150. o.

Beszélgetés Lakner Lászlóval. In: Hatvanas évek. Új törekvések a magyar képzömüvészetben. Kiállítási katalógus, Magyar Nemzeti Galéria, 1991. március 14. - június 30. Összeáll. Beke László, Dévényi István, Horváth György. Szerk. Nagy Ildikó. Képzőmüvészeti Kiadó Magyar Nemzeti Galéria - Ludwig Múzeum, Budapest, 1991. 125137. o.

Beszélgetés Papp Tiborral (Párizs). In: In memoriam Pilinszky. Összeállította és az interjúkat készítette Bogyay Katalin. Officia Nova, Budapest, 1990. 69-71. o.

Beszélgetés Szentjóby Tamással. In: Jelenlét. Szógettó. Válogatás az új magyar avantgarde dokumentumaiból. Az ELTE-BTK irodalmimüvészeti folyóirata, 1989/1-2., 14-15. sz. 255-262. o.

Beszélgetés Szentjóby Tamással. In: Translocal.org. Készítette Maja Fowkes és Reuben Fowkes, 2008. március 2. Interneten: http://www.translocal.org/revolutioniloveyou/stauby.html; 2012. 03. 10. 
Beszélgetéstöredék Erdély Miklóssal. In: Fotó. 1989. április, XXXVI. évf. 4. sz. 150-151. o.

Beuys, Joseph: Not Just a Few Are Called, But Everyone. In: Art in Theory - 1900-1990 - An Anthology of Changing Ideas. Ed. Charles Harrison and Paul Wood. Blackwell Publishers Inc, Oxford UK \& Cambridge USA, 1999. 889-892. o.

Békés Izabella: St. Auby Tamás, a nem mủvészet müvésze. In: Bárka. 2010. XVIII. évf. 4. sz. 78-84. o.

Bényi Csilla, Galántai György, Sasvári Edit: Eseménytörténet 1966-1974. In: Törvénytelen avantgárd. Galántai György balatonboglári kápolnamüterme 1970-1973. Szerk. Klaniczay Júlia és Sasvári Edit. Artpool-Balassi, Budapest, 2003. 91-190. o.

Bibó István: A zsidókérdésről. Szerk. Balog Iván. Argumentum Kiadó Bibó István Szellemi Műhely, Budapest, 2010.

Bihari László: Kiveszőben lévő mentalitás. (Beszélgetés Beke Lászlóval és Peternák Miklóssal). In: Magyar Hírlap. Ahogy tetszik. A Magyar Hírlap kulturális magazinja. 1998. október 3. XXXI. évf. 232. sz. 13. o.

Bohár András: A müvészetfogalom változásának dimenziói. In: A modern poszt-jai. Esszék, tanulmányok, dokumentumok a 80-as évek magyar képzömüvészetéröl. Szerk. Keserü Katalin. ELTE, Bölcsészettudományi Kar, Budapest, 1994. 29-40. o.

Bohr, Niels: Az atomok és az emberi megismerés. In: Bohr, Niels: Atomfizika és emberi megismerés. Ford. Nagy Tibor. Gondolat, Budapest, 1964. 123-138. o.

Bohr, Niels: Biológia és atomfizika. In: Bohr, Niels: Atomfizika és emberi megismerés. Ford. Nagy Tibor. Gondolat, Budapest, 1964. 24-37. o.

Bohr, Niels: Ismeretelméleti kérdések a fizikában és az emberi kultúrák. In: Bohr, Niels: Atomfizika és emberi megismerés. Ford. Nagy Tibor. Gondolat, Budapest, 1964. 38-50. o.

Bohr, Niels: Vita Einsteinnel az atomfizika ismeretelméleti problémáiról. In: Bohr, Niels: Atomfizika és emberi megismerés. Ford. Nagy Tibor. Gondolat, Budapest, 1964. 51-99. o.

Bolgár Kálmán: Gondolatok a Stúdió 66-ról. In: Müvészet. 1966/12. sz. 4547. 0.

Boros Géza: A szabadság kapujában. Kommentár egy Szentjóby-műhöz. In: Balkon. 1999/1-2. sz. 31-32. o.

Boros Géza: Leletmentés. Erdély Miklós fotómozaikjai. In: Artmagazin. 2014. XII. évf. 6. sz. 70. sz. 28-36. o.

Boros Géza: Örizetlen pénz. Jövőkötvény. Két 1956-os konceptualista akció. In: Kritika. 1996/10. sz. 26-27. o. 
Boros Géza: Szükített spektrumok. Erdély, Hencze, Jovánovics. In: Müértő. 2014. szeptember, XVII. évf. 9. sz. 8. o.

Bóka B. László: Érdektelen a Fabulon-mozaik? In: Népszava. 2001. november 10. CXXIX. évf. 262. sz. 10. o.

Bóka B. László: Kié lehet Erdély Miklós híres mozaikja? In: Népszava. 2000. augusztus 29. CXXVIII. évf. 202. sz. 12. o.

Brendel János: Signum temporis. Megjegyzések Erdély Miklós művészeti írásaihoz. In: Magyar Mühely. 1999. XXXVII. évf. 110-111. sz. 2428. 0 .

Buber, Martin: Száz chászid történet. Ford. Pfeiffer Izsák. Magyar Zsidók Pro Palesztina Szövetsége, Budapest, 1944.

Bubner, Rüdinger: A jelenkori esztétika némely feltételéröl. Ford. Mesterházi Miklós. In: Athenaeum. 1991. I. kötet 1. füzet, 151-189. 0 .

Bujdosó Alpár: A semmi, az üres jel, a polivalencia és a nyílt tér. In: Magyar Mühely. 1999. XXXVII. évf. 110-111. sz. 69-74. o.

Bulla Károly: Egy hónap falun. In: Film Színház Muzsika. 1981. október 17. XXX. évf. 42. sz. 10. o.

Bürger, Peter: Az avantgárd elmélete. Ford. Seregi Tamás. Universitas Szeged Kiadó, Szeged, 2010.

Chengery Pap Elemér, Dr.: Az okkult-fizikai ülések lefolytatásánál szükséges tudnivalók. In: Metapsychikai Folyóirat. 1933. márciusáprilis, II. évf. 3-4. sz. 68-72. o.

Csapó György: Közelképek. Beszélgetések. Képzőművészeti Kiadó, Budapest, 1983.

Csáji Attila: Billenő idő. Püski Kiadó, Budapest, 2009.

Csáki Judit: Színészparádé Kaposvárott. Turgenyev: Egy hónap falun. In: Népszava. 1981. október 29. CIX. évf. 254. sz. 6. o.

Csorba László: Izraelita felekezeti élet Magyarországon a vészkorszaktól a nyolcvanas évekig. In: Hét évtized a hazai zsidóság életében II. Szerk. Lendvai L. Ferenc, Sohár Anikó, Horváth Pál. MTA Filozófiai Intézet, Budapest, 1990. 61-190. o.

Deréky Pál: A magyar neoavantgárd irodalom. In: Né/ma? Tanulmányok a magyar neoavantgárd köréböl. Szerk. Deréky Pál és Müllner András. Ráció Kiadó, Budapest, 2004. 11-38. o.

Deréky Pál - Wernitzer Júlia: Művészet és utópia a bécsi „1984”kiállításon. In: Müvészet. 1985/1. sz. 41-44. o.

Dékei Krisztina: A magyar irodalom és képzőmüvészet néhány kapcsolódási pontja (1965-1974). In: Kép - írás - müvészet. Tanulmányok a 19-20. századi magyar képzőmüvészet és irodalom 
kapcsolatáról. Szerk. Kékesi Zoltán és Peternák Miklós. Ráció Kiadó, Budapest, 2006. 44-68. o.

Dobó László: Tudomány a költészetben. Gondolatok Erdély Miklós Sejtések I. és Sejtések II. című költeményéről. In: Új Symposion. 1984/1-2. sz. 27-28. o.

Dokumentumok a Szürenon és kisugárzása címü tanulmányhoz. (Összeállította: Mezei Ottó). In: Ars Hungarica. 1991/1. sz. 111-137. o.

Dr. Schrenck-Notzing tanár Budapesten. In: Égi Világosság. 1923. november, XXV. évf. 11. sz. 431-434. o.

Egy Kondor-dokumentum. In: Kritika. 1973/2. sz. 14. o.

Egy metapsychikus: Az a bárgyu halhatatlan libazsíros vatta! (Levél a szerkesztőkhöz.) In: Metapsychikai folyóirat. 1933. január-február, II. évf. 1-2. sz. 46. o.

Egyetemi Ifjúság. 1956. november 4. I. évf. 6. sz. o.n.

Einstein, Albert: A különleges és az általános relativitás elmélete. Ford. Vámos Ferenc. Pantheon Irodalmi intézet R.-T., Budapest, 1921.

Einstein, Albert: A speciális és általános relativitás elmélete. Ford. Vámos Ferenc. Gondolat, Budapest, 1963.

Elhallgatott Holocaust - Sho'ah musteret - Bisterdo Holocaust - The hidden Holocaust. Kiállítási katalógus, Mücsarnok - Kunsthalle, Budapest, 2004. március 18. - május 31.

Elior, Rachel: The Paradigms of Yesh and Ayin in Hasidic Thought. In: Hasidism Reappraised. Ed. by Ada Rapoport-Albert. The Littman Library of Jewish Civilization, London - Portland, Oregon, 1997. 168-179. o.

Ember Mária: Happening és antihappening. In: Film Színház Muzsika. 1966. május 13. 18. o.

Ember Mária: Magnósok járnak közöttünk? In: Kritika. 1973/4. sz. 2. o.

Eörsi István: A besúgójelentés mint kultúrtörténeti forrásmunka. In: Élet és Irodalom. 2002. november 22. 8. o.

Erdély, az ellenguru. A müvészet föltalálója. Legjobb barát, legjobb ellenség. (Dobai Péterrel, Eörsi Istvánnal, Konrád Györggyel, Litván Györggyel, Nagy Tamással és Rajk Lászlóval beszélget Váradi Júlia.) In: 168 Óra. 1991. november 5. III. évf. 44. sz. 32-33. o.

Erdély Dániel: A múlt mozaikjai. In: Kultúra és Közösség. 1990. szeptember-október-november-december, XVII. évf. 4. sz. 147. o.

Erdély Dániel: Mi kis családunk. In: Árgus. 1992. január-február, III. évf. 1. sz. 90-102. o. 
Erdély Dániel: „Mi kis” életünk. In: Árgus. 1991. szeptember-október, II. évf. 5. sz. 89-100. o.

Erdély Dániel: „Mi kis” életünk. In: Árgus. 1992. március-április, III. évf. 2. sz. 58-69. o.

Erdély Dániel: Tárgytörténet. In: Ponticulus Hungaricus. 2005. október, IX. évf. $10 . \quad$ sz. Interneten: http://members.iif.hu/visontay/ponticulus/rovatok/hidverok/spidron1. html; 2013. 03. 10.

Erdély Dániel, Mújdricza Péter, Szenes Zsuzsa: $\sqrt{-1}$, mint ANTIBÁLVÁNY, avagy a mélypont ünnepélye. Beszélgetés Erdély Miklós mütermében. In: Pompeji. 1993/1-2. sz. 78-115. o.

Erdély Miklós: A filmröl. (Filmelméleti írások, forgatókönyvek, filmtervek, kritikák). Válogatott írások II. Összeáll. Peternák Miklós. Szerk. Beke László, Szőke Annamária. Balassi Kiadó - BAE Tartóshullám Intermédia, Budapest, 1995. (AF.)

Erdély Miklós: A happeningről. Istentisztelet a valósághoz. In: Filmvilág. 1999. március, XLII. évf. 3. sz. 10-11. o.

Erdély Miklós: A Möbius-bemutatóhoz. Sokszorosított felhívás, 1975.

Erdély Miklós: $A$ női gonoszságról. Interneten: http://www.artpool.hu/Erdely/mutargy/A_noi_gonoszsagrol.html; 2013. 04. 23.

Erdély Miklós: A titokról. In: Új Symposion. 1985/1-2. sz. 12-13. o.

Erdély Miklós: Kollapszus orv. Magyar Mühely, Párizs, 1974. (KO.)

Erdély Miklós: Levelek Jeruzsálembe. Bevezette és kommentálja Hajdu András. In: Múlt és jövő. 2008. 2-3. sz. 119-126. o.

Erdély Miklós: Második kötet. Vál., szerk. Beke László, Peternák Miklós és a Magyar Műhely szerkesztősége. Magyar Műhely, Párizs, Bécs, Budapest, 1991. (MK.)

Erdély Miklós: Müvészeti irások. (Válogatott müvészetelméleti tanulmányok I.). Szerk. Peternák Miklós. Képzőmüvészeti Kiadó, Budapest, 1991. (MI.)

Erdély Miklós: Mủvészkijárat (1979. június). In: KREATIVITÁSI GYAKORLATOK, FAFEJ, INDIGO - Erdély Miklós müvészetpedagógiai tevékenysége 1975-1986. Összeállította Hornyik Sándor, Szőke Annamária. MTA Művészettörténeti Kutatóintézet Gondolat Kiadó - 2B Alapítvány - Erdély Miklós Alapítvány, Budapest, 2008. 239-243. o. Első megjelenése: In: Indigo. [A csoport 1977-81 közötti kiállításainak a katalógusa.] Szerk. Erdély Dániel, Nemesi Tivadar. Budapest, 1981. 28-29. o.

Erdély Miklós: Szolidaritási akció. Interneten: http://labor.c3.hu/erdelymiklos-szolidaritas-akcio/; 2013. 04. 05. 
Erdély Miklós - Beke László: Egyenrangú interjú. 1978. április 16. In: Hasbeszélö a gondolában. A Tartóshullám antológiája. (Jóvilág 3.). (Cápa 4.). Szerk. Beke László, Csanády Dániel, Szőke Annamária. Bölcsész Index, Budapest, 1987. 181-192. o.

Erdély Miklós Kondor Béláról. Részlet egy 1981 körül készült magnófelvételből. In: Beszélő. 1999. január, III. folyam, IV. évf. 1. sz. 104-115. o. A hangfelvétellel együtt lásd: http://artpool.hu/Erdely/Kondor.html; 2013. 07. 28.

Erdély Miklós mozaikja úton a megmenekülés felé. In: Népszava. 2000. július 5. CXXVIII. évf. 155. sz. 11. o.

Expozíció. Fotó/müvészet. Kiállítási katalógus, Hatvany Lajos Múzeum, Hatvan, 1976. október 24. - 1977. január 31. A Hatvany Lajos Múzeum Füzetei No 2., MÉM STAGEK sokszorosító 367/76

Fabényi Júlia: Előszó. In: Iparterv csoport - Progresszivitás és illúzió. A magyar avant-garde harmadik nemzedéke. 1968-1969. Kiállítási katalógus, Párizsi Magyar Intézet, Párizs, 2010. 24-25. o.

Favrholdt, David: Niels Bohr's Philosophical Background. Historiskfilosofiske Meddelelser 63. Det Kongelige Danske Videnskabernes Selskab. The Royal Danish Academy of Sciences and Letters. Munksgaard, Copenhagen, 1992.

Fehér Dávid: Emlékmü hóból. In memoriam Attalai Gábor (1934-2011). In: Élet és Irodalom. 2011. augusztus 19. LV. évf. 33. sz. 22. o.

Fekete Gyula: Tengercsepp. In: Magyar Fórum. 1992. március 12. IV. évf. 11. sz. 12. o.

Filliou, Robert: Teaching and Learning as a Performing Arts. By Robert Filliou and the READER if he wishes, with the participation of John Cage, Benjamin Patterson, George Brecht, Allen Kaprow, Marcel, Vera and Bjoessi and Karl Rot, Dorothy Iannone, Diter Rot, Joseph Beuys. König Verlag, Cologne and New York, 1970.

Focillon, Henri: A formák élete. A nyugati müvészet. Ford. Vajda András. Gondolat, Budapest, 1982.

Forgács Éva: A kultúra senkiföldjén - Avantgárd a magyar kultúrában. In: A második nyilvánosság - XX. századi magyar müvészet. Összeállította Hans Knoll. Enciklopédia Kiadó, Budapest, 2002. 1065. 0.

Forgács Éva: Egy mítosz természetrajza. Erdély Miklós és a neoavantgárd magánya. In: 2000. MCMXCIII. október, 5. évf. 10. sz. 36-40. o.

Forgács Éva: „... a nem elvárható dolgok megjelenítése”. Erdély Miklós életműkiállítása. In: Magyar Napló. 1991. november 29. III. évf. 16. sz. 34-35. o. 
Forgács Éva: A neoavantgárd magánya. Erdély Miklós: Művészeti írások. (Válogatott müvészetelméleti tanulmányok). In: Új Müvészet. 1992. április, III. éfv. 4. sz. 81-84. o.

Forgács Éva: „... önmagát (oda-vissza) kölcsönösen meghatározza”. Időmetszetek, párhuzamos idősíkok az Időutazásban. In: Magyar Mühely. 1999. XXXVII. évf. 110-111. sz. 150-153. o. Újraközölt variáns: Forgács Éva: „... önmagát (oda-vissza) kölcsönösen meghatározza". Időmetszetek, párhuzamos idősíkok Erdély Miklós Időutazásban. In: Uö: A Duna Los Angelesben. Müvészeti írások. Kijárat Kiadó, Budapest, 2006. 64-70. o.

Forradalmunk nagyszerü erkölcse. In: Magyar Szabadság. 1956. november 3. I. évf. 3. sz. 2. o.

Földényi F. László: „...saját lábába botlik...” Erdély Miklós és az irodalom. In: Magyar Mühely. 1999. XXXVII. évf. 110-111. sz. 3236. o. Újraközölve: Földényi F. László: „...saját lábába botlik...” Erdély Miklós és az irodalom. In: Né/ma? Tanulmányok a magyar neoavantgárd köréböl. Szerk. Deréky Pál és Müllner András. Ráció Kiadó, Budapest, 2004. 72-77. o.

Görényi Frigyes: A vállalt előd adva van. Marcel Duchamp magyarországi recepciója. In: VISZONTLÁTÁSRA! DUCHAMP. Készült a VISZONTLÁTÁSRA! • Marcel Duchamp magyarországi hatásai c. kiállításhoz, Budapest Galéria Kiállítóháza, 1996. november 14. december 8. Budapest Galéria, Budapest, 1996-2000. 5-24. o.

Greskovics Eszter: Az „R”-kiállítás (1970) rekonstrukciója. In: Balkon. 2014/1. sz. 9-13. o.

Gribbin, John: Schrödinger macskája. Kvantumfizika és valóság. Ford. Dr. Both Előd. Akkord Kiadó, 2001.

Groh, Klaus: Aktuelle Kunst in Osteuropa. DuMont Aktuell, Köln, 1972.

Grünhut Adolf: Tanulmányok a spiritizmus köréböl. Magnetizmus, szomnambulizmus, mediumizmus. I-II. Szellemi Búvárok Pesti Egylete, Budapest, 1921.

Gy.: Pesti utcán. In: Valóság. 1956. november 3. I. évf. 4. sz. 4. o.

Gyenge Zoltán: Schelling élete és filozófiája. Attraktor, Máriabesenyő Gödöllö, 2005.

György Péter: A hely szelleme. [Recenzió a Törvénytelen avantgárd. Galántai György balatonboglári kápolnamüterme 1970-1973 címü kötetről.] In: BUKSZ. 2004 tél, 16. évf. 4. sz. 328-335. o. Interneten: http://www.artpool.hu/boglar/sajto/buksz_gyorgyp.html; 2013. 07. 28.

György Péter: (Erdély Miklósról). Elhangzott a Szabad Európa Rádióban, 1991-ben. Kézirat, 1991.

György Péter: Erdély Miklós - A szelíd botrány müvésze. In: Holmi. 1992/8. sz. 1170-1181. o. 
György Péter: Mostantól fogva ez lesz a múlt. Hatvanas évek. In: György Péter: Az elsüllyedt sziget. Képzőművészeti Kiadó, Budapest, 1992. 94-121. o.

György Péter: Az elsüllyedt sziget. In: György Péter: Az elsüllyedt sziget. Képzőművészeti Kiadó, Budapest, 1992. 5-46. o.

Győri Szabó Róbert: Zsidóság és kommunizmus a Kádár-korszakban III. Zsidóság, cionizmus, antiszemitizmus az 1967-es arab-izraeli háború utáni években. In: Valóság. 2008. május, LI. évf. 5. sz. 79-97. o.

Hajdu István: Az illúzió progresszivitása. A magyar avant-garde harmadik nemzedéke. In: Iparterv csoport - Progresszivitás és illúzió. A magyar avant-garde harmadik nemzedéke. 1968-1969. Kiállítási katalógus, Párizsi Magyar Intézet, Párizs, 2010. 29-31. o.

Hajdu István: Concept Art. Kísérlet egy müfajtalan műfaj rendszerezésére. In: Tájékoztató. Magyar Képzőművészek Szövetsége, 1975/4. sz., 1976/1. sz., 1976/2. sz. Interneten: http://www.c3.hu/collection/koncept/help.html; 2012. 11. 23.

Hajdu István: Hajdu István válasza a (Zsadányi) aláírású cikkre. Kézirat, Artpool, 1984.

Hajdu István: Kalcedon - a kétely, a kétség, a kettősség, a hármasság és a négyesség. In: Magyar Mühely. 1999. XXXVII. évf. 110-111. sz. 156-161. o.

Hajdu István: On the Road. prof. Piotr Piotrowski varsói müvészettörténésszel beszélget Hajdu István. Ford. Bába Veronika. In: Balkon. 1996/6. sz. 32-35. o.

Hajnal András, Hamburger Péter: Halmazelmélet. Nemzeti Tankönyvkiadó, Budapest, 1994.

Halász András: Közvetítés pohárban. In: Magyar Mühely. 1983. július, XXI. évf. 67. sz. 41-48. o.

Havas Fanny: Egy valódi mester. Beszélgetés Maurer Dórával. In: Beszélö. A senki földjén. A Beszélö melléklete Erdély Miklósról. 1991. október 26. Új folyam II. évf. 43. sz. 3-7. o. A beszélgetés egy részlete újraközölve: In: KREATIVITÁSI GYAKORLATOK, FAFEJ, INDIGO Erdély Miklós müvészetpedagógiai tevékenysége 1975-1986. Összeállította Hornyik Sándor, Szőke Annamária. MTA Művészettörténeti Kutatóintézet - Gondolat Kiadó - 2B Alapítvány Erdély Miklós Alapítvány, Budapest, 2008. 71-74. o.

Havasréti József: A strukturalizmustól a kabbaláig. Mágia és szemiotika Erdély Miklós filmes írásaiban. In: Metropolis. 2007. április, XI. évf. 4. sz. 92-99. o.

Havasréti József: Széteső dichotómiák. Színterek és diskurzusok a magyar neoavantgárdban. Gondolat Kiadó - Artpool - PTE Kommunikációés Médiatudományi Tanszék, Budapest, 2009. 
Hawking, Stephen W.: Az idö rövid története. Ford. Molnár István. Maecenas Könyvek - Talentum Kft., Budapest, 1998.

Hegel, G. W. F.: Esztétikai előadások I-III. Szerk. Lukács György. Ford. Zoltai Dénes. Akadémiai Kiadó, Budapest, 1952.

Hegyi Dóra - László Zsuzsa: How Art Becomes Public. In: Parallel Chronologies. An exhibition in newspaper format. Budapest, 2009. 215. 0 .

Hegyi Dóra - László Zsuzsa: Interjú St.Auby Tamással. In: Az ebéd (In memoriam Batu kán). HAPPENING Budapest H 1966. The Lunch (In Memoriam Batu Khan). Szerk. László Zsuzsa, St. Turba Tamás. Ford. Polonyi Csaba. Tranzit Hungary Közhasznú Egyesület, Budapest, 2011. 16-20. o., 51-55. o. Első megjelenés: Dóra Hegyi and Zsuzsa László in conversation with Tamás St.Auby. In: Gallery Nova Newspapers. 2009. 19/20. sz. 37-41. o.

Hegyi Lóránd: Az antimüvészet pályái és Erdély Miklós helyzete. In: Magyar Mühely. 1983. július, XXI. évf. 67. sz. 11-20. o.

Hegyi Lóránd: [Bevezető]. In: Pécsi Mühely 1970-1980. The Workshop of Pécs. Kiállítási katalógus, Székesfehérvár, Csók István Képtár, 1980. május 11. - augusztus 24. Az István király Múzeum Közleményei, D. sorozat 138. sz., 8-10. o.

Hegyi Lóránd: Előszó az Új szenzibilitás IV. kiállításhoz. Az új szenzibilitás és az új festészet kibontakozása (1980-1986) c. rész. In: Új szenzibilitás IV. Kiállítási katalógus, Pécsi Galéria, 1987. Újraközölve: Az új szenzibilitás és az új festészet kibontakozása (1980-1986). In: A modern poszt-jai. Esszék, tanulmányok, dokumentumok a 80-as évek magyar képzömüvészetéröl. Szerk. Keserü Katalin. ELTE, Bölcsészettudományi Kar, Budapest, 1994. 89-97. 0.

Hegyi Lóránd: Film/művészet. Kiállítás a magyar kísérleti film történetéröl. In: Filmvilág. 1983. július, XXVI. évf. 7. sz. 9-13. o.

Hegyi Lóránd: Pinczehelyi. Pécs, 1995.

Hegyi Lóránd: Új szenzibilitás. Magvető, Gyorsuló idő sorozat, Budapest, 1983.

Heidegger, Martin: „... költőien lakozik az ember...” - Válogatott írások. Vál., szerk. Pongrácz Tibor. Ford. Bacsó Béla, Hévizi Ottó, Kocziszky Éva, Pongrácz Tibor, Szijj Ferenc, Vajda Mihály. T-Twins Kiadó, Pompeji, Budapest, Szeged, 1994.

Heisenberg, Werner: A mai fizika világképe. In: Heisenberg, Weiner: Válogatott tanulmányok. Ford. Morlin Zoltán. Gondolat, Budapest, 1967. 17-67. o.

Heisenberg, Werner: A rész és az egész. Beszélgetések az atomfizikáról. Ford. Falvay Mihály. Gondolat, Budapest, 1975. 
Heisenberg, Werner: Fizika és a filozófia. In: Heisenberg, Werner: Válogatott tanulmányok. Ford. Kis István. Gondolat, Budapest, 1967. 69-197. o.

Heitler László: Müteremlátogatás Hencze Tamásnál. In: Életünk. 1971. november-december, II. évf. 6. sz. 567-571. o.

Heller Ágnes: A „zsidókérdés” megoldhatatlansága. Miért születtem hébernek, miért nem inkább négernek? Múlt és Jövő Kiadó, Budapest, 2004.

Higgins, Hannah: Fluxus experience. University of California Press, Berkeley, Los Angeles, London, 2002.

Hock Beáta: Attalai Gábor. (Részlet a Kállai Ernő ösztöndij segítségével végzett performansz-kutatási beszámolóból, 2000). Interneten: http://www.artpool.hu/Attalai/Hock2.html; 2012. 02. 03.

Hock Beáta: Attalai Gábor. (Interjú). In: Balkon. 2001/6-7. sz. 6-8. o.

Hornyik Sándor: A fekete lyukak esztétikája. Kritikai teória és praxis Erdély Miklósnál. In: Balkon. 2006/6. sz. 4-10. o.

Hornyik Sándor: Avantgárd kvarkok. Erdély Miklós: Három kvarkot Marke királynak. In: Kép - írás - müvészet. Tanulmányok a 19-20. századi magyar képzömüvészet és irodalom kapcsolatáról. Szerk. Kékesi Zoltán és Peternák Miklós. Ráció Kiadó, Budapest, 2006. 7-25. o.

Hornyik Sándor: Avantgárd tudomány? A modern természettudományos világkép recepciója Gyarmathy Tihamér, Csiky Tibor és Erdély Miklós munkásságában. Akadémiai Kiadó, Budapest, 2008.

Hornyik Sándor: Konceptualizmus a kilencvenes évek magyar képzőmüvészetében. In: Müvészettörténeti Értesitö. 2002/3-4. sz. 251-264. o.

Hornyik Sándor: Naiv realizmus és „természettudományos koncept”. A modern természettudomány helye Erdély Miklós müvészetében. In: Magyar Mühely. 2004. XLIII. évf. 131. sz. 16-50. o.

Hornyik Sándor - Szőke Annamária: Akvarell [1980. november]. In: KREATIVITÁSI GYAKORLATOK, FAFEJ, INDIGO - Erdély Miklós müvészetpedagógiai tevékenysége 1975-1986. Összeállította Hornyik Sándor, Szőke Annamária. MTA Művészettörténeti Kutatóintézet Gondolat Kiadó - 2B Alapítvány - Erdély Miklós Alapítvány, Budapest, 2008. 295-303. o.

Idel, Moshe: Martin Buber and Gershom Scholem on Hasidism: A Critical Appraisal. In: Hasidism Reappraised. Ed. by Ada Rapoport-Albert. The Littman Library of Jewish Civilization, London - Portland, Oregon, 1997. 389-403. o.

IPARTERV 68-80. Kiállítási katalógus, Iparterv házi nyomdája, Budapest, 1980. 
Itt fü terem. Marno János és Antal István beszélgetése Szentjóby Tamás költészetéről és még sok minden másról. In: Holmi. 1990. szeptember, II. évf. 9. sz. 1024-1036. o.

Jolsvai András: Ó, azok a hatvanas évek! Rejtett közösségek hálózata. (Beszélgetés Deák Lászlóval). In: Magyar Nemzet. 1991. március 14. LIV. évf. 62. sz. 12. o.

Jonas, Hans: Az istenfogalom Auschwitz után. Zsidó gondolatok. In: 2000. MCMXCVI augusztus, 8. évf. 8. sz. 56-61. o.

Jovánovics György: Emlék-képek. Kép-emékek. In: Orpheus. 1992/4. sz. 92-115. 0.

Jovánovics György: Mennyezetreszorító szerkezet, 1971. A Mennyezetreszorító szerkezet használatával készült müalkotások. In: http://labor.c3.hu/jovanovics-gyorgy-mennyezetreszorito-szerkezet1971/; 2014. 01. 20.

Juhász József: Volt egyszer egy Jugoszlávia. A délszláv állam története. Aula Kiadó - Budapesti Közgazdaságtudományi Egyetem, Budapest, 1999.

Kamondy László: Ebéd in memoriam Batu kán. Meditáció az első hazai happeningről. In: Tükör. 1966. szeptember 13. 37. sz. 10-12. o.

Kapitány András: Erdély Miklós munkáinak bemutatása diagram segítségével, 1969-1979. Interneten: http://www.c3.hu/collection/em/; 2013. 04. 07.

Kaprow, Allan: Assemblage, Environmentek \& Happeningek. Szerk. Szőke Annamária. Ford. Horányi Attila. Artpool - Balassi Kiadó - BAE Tartóshullám, Budapest, 1998.

Kenedi János: Emberekről, eszmékről, politikáról. Csizmadia Ervin interjúja. 1. rész. In: Valóság. 1990. március, XXXIII. évf. 3. sz. 5369. 0.

Kerékgyártó István: Stúdió 66. In: Tükör. 1966. április 26. 17. sz. 7-9. o.

Keserü Katalin: A nyelv flörtje a müvészettel Magyarországon. In: Holmi. 1990. szeptember, II. évf. 9. sz. 1020-1023. o.

Keserü Katalin: Variációk a pop artra. Fejezetek a magyar müvészetböl 1950-1990. Új Művészet Kiadó, é.n.

Kibédi Varga Áron: Megjegyzések Erdély Miklós Téziseihez. In: Magyar Mühely. 1981. július, XIX. évf. 64. sz. 34-35. o.

Kicsiny Balázs: Óramotivum és eszkatológia. A mérhető és a mérhetetlen ábrázolása. DLA értekezés, Magyar Képzőmüvészeti Egyetem, Doktori Iskola, Budapest, 2008.

„Kicsit úgy nézte ezeket a dolgokat, mint a tyúk a piros kukoricát...” Erdély Miklós Kondor Béla és az avantgárd kapcsolatáról - archív interjúszöveg 1983-ból. A beszélgetést készítette: Rényi András. A 
csak legépelt példányban fennmaradt szöveget gondozta, jegyzetekkel ellátta: Szőke Annamária. In: Müút. 2013/037. sz. 50-58. o.

Kiss Antal: Magasztos eszme. In: Kis Ujság. 1956. november 3. I. évf. 3. sz. 3. o.

Kollár József: Agyírás, elmeolvasás. Erdély Miklós retrospektív kiállítása. In: Új Müvészet. 1999. március, X. évf. 3. sz. 4-7. o.

Konrád György: Pilinszky. In: In memoriam Pilinszky. Összeállította és az interjúkat készítette Bogyay Katalin. Officia Nova, Budapest, 1990. 86-88. o. Újraközölve: Konrád György: Csodafigurák. Arcképek, pillanatfelvételek. Noran Kiadó, Budapest, 2006. 5-11. o.

Kortárs képzőmüvészeti szöveggyüjtemény. Jegyzet gyanánt. Vál. Tolvaly Ernő. Szerk. Lengyel András, Tolvaly Ernő. Ford. Beke László, Birkás Ákos, Bodnár Szilvia, Farkas István, Gáthy Vera, Fázsy Anikó, Jósvai Lídia, Konok István, Sebők Zoltán, Sümeghy Péter, Szántó Tamás, Takács Ferenc. A \& E ’93 Kiadó, 1995.

Kosuth, Joseph: Art after Philosophy. In: Joseph Kosuth: Art after Philosophy and After - Collected Writings, 1966-1990. ed. Gabriele Guerico. The MIT Press, Cambridge, Massachusetts, London, England, 1991. 13-32. o.

Kosuth, Joseph: Context text. In: Joseph Kosuth: Art after Philosophy and After - Collected Writings, 1966-1990. ed. Gabriele Guerico. The MIT Press, Cambridge, Massachusetts, London, England, 1991. 8388. 0.

Kosuth, Joseph: Introduction to Function. In: Joseph Kosuth: Art after Philosophy and After - Collected Writings, 1966-1990. ed. Gabriele Guerico. The MIT Press, Cambridge, Massachusetts, London, England, 1991. 41-42. o.]

Kosuth, Joseph: The Play of the Unsayable: A Preface and Ten Remarks on Art and Wittgenstein. In: Joseph Kosuth: Art after Philosophy and After - Collected Writings, 1966-1990. ed. Gabriele Guerico. The MIT Press, Cambridge, Massachusetts, London, England, 1991. 245250. o.

Kosuth, Joseph: 'Zeno Az Ismert Világ Határán'. 'Zeno At The Edge Of The Known World'. 'Zeno All'Orlo Del Mondo Conosciuto'. Kiállítási katalógus, Velencei Biennále, XLV Nemzetközi Művészeti Kiállítás, Magyar Pavilon, 1993.

Kovalovszky Márta: Erdély Miklós: Időutazás. In: Fehérvári Müsor. 1988. V. évf. 2. sz. 13. o.

Kovalovszky Márta: „Jég és aszály között játszi évszak” - A hatvanas évek. In: A második nyilvánosság - XX. századi magyar müvészet. Összeállította Hans Knoll. Enciklopédia Kiadó, Budapest, 2002. 170199. o. 
Kovalovszky Márta: Pinczehelyi Sándor. Pécsi Galéria és Vizuális Müvészeti Mühely, Pécs, 2010.

Kovács András: A zsidókérdés a mai magyar társadalomban. In: Zsidóság az 1945 utáni Magyarországon. Szerk. Kende Péter. Magyar Füzetek, Párizs, 1984. 3-35. o.

Kovács András: Magyar zsidó politika a háború végétől a kommunista rendszer bukásáig. In: Múlt és Jövő. 2003. XIV. évf. 3. sz. 5-39. o.

Kovács Gyula: Súdió 66. In: Kortárs. 1966. augusztus, X. évf. 8. sz. 13371340. 0 .

Kozma György: Kalandor lélek avagy Erdély Miklós ősisége. In: Magyar Mühely. 1999. XXXVII. évf. 110-111. sz. 49-56. o.

Kótun Viktor: Neoavantgárd müvek rekonstruálásának gyakorlata. DLA értekezés, Magyar Képzőmüvészeti Egyetem, Doktori Iskola, Budapest, 2013.

Körner Éva: Az abszurd mint koncepció. Jelenetek a magyar koncept art történetéből. I. rész. In: Balkon. 1993/1. sz. 22-25. o.

Körner Éva: Az abszurd mint koncepció. Jelenetek a magyar koncept art történetéből. II. rész. In: Balkon. 1993/2. sz. 10-18. o.

Körner Éva: Az abszurd mint koncepció - A magyar konceptualizmus jelenségei. The Absurd as Concept - Phenomena of Hungarian Conceptualism. L'assurdo come concezione - I fenomeni del concettualismo ungherese. In: Kosuth, Joseph: 'Zeno Az Ismert Világ Határán'. 'Zeno At The Edge Of The Known World'. 'Zeno All'Orlo Del Mondo Conosciuto’. Kiállítási katalógus, Velencei Biennále, XLV Nemzetközi Müvészeti Kiállítás, Magyar Pavilon, 1993. 185198. о., 208-219. о.

Körner Éva: Magyar avantgárd - izmusok nélkül. I. rész. In: Új Müvészet. 1994/4-5. sz. 4-8. o.

Körner Éva: Magyar avantgárd - izmusok nélkül. II. rész. In: Új Müvészet. 1994/6. sz. 4-9. o.

Közelítések. Bizonyos müvészet-elméleti fogalmakról. A beszélgetés résztvevői: Bacsó Béla, Andrási Gábor, Bárdosi József, Bohár András, Hegyi Lóránd, Keserü Katalin, Novotny Tihamér, Sebeő Talán, D. Udvary Ildikó és Forgács Éva. In: A modern poszt-jai. Esszék, tanulmányok, dokumentumok a 80-as évek magyar képzömüvészetéről. Szerk. Keserü Katalin. ELTE, Bölcsészettudományi Kar, Budapest, 1994. 309-335. o.

Kőhalmi Péter: A kreativitás. In: C3 Gyüjtemény. 2016. április. Interneten: http://www.c3.hu/collection/kohalmi/kreativitas.html; 2016. 04. 21.

Kőhalmi Péter: A preszókratikától a kvantummechanikáig. In: C3 Gyüjtemény. $2016 . \quad$ április. Interneten: 
http://www.c3.hu/collection/kohalmi/preszokratika.html; 2016. 04. 21.

Köhalmi Péter: A zen út fokozatai. In: C3 Gyüjtemény. 2016. április. Interneten: http://www.c3.hu/collection/kohalmi/zen.html; 2016. 04. 21.

KREATIVITÁSI GYAKORLATOK, FAFEJ, INDIGO - Erdély Miklós müvészetpedagógiai tevékenysége 1975-1986. Összeállította Hornyik Sándor, Szőke Annamária. MTA Művészettörténeti Kutatóintézet Gondolat Kiadó - 2B Alapítvány - Erdély Miklós Alapítvány, Budapest, 2008. (KGYFI.)

Krusovszky Dénes, Urfi Péter: „Nehézkesen forduló tankhajó” (interjú Kukorelly Endrével). In: Puskin Utca. 2008/4. sz. 29-32. o.

Krusovszky Dénes, Urfi Péter: „Egy szük terem” (interjú György Péterrel). In: Puskin Utca. 2008/4. sz. 25-28. o.

Krusovszky Dénes, Szabó Marcell, Urfi Péter: Közegészségtelen töredékek (levélinterjú St. Auby Tamással). In: Puskin Utca. 2008/4. sz. 15-24. o.

Kukorelly Endre: 666 999 000 . Előbb némi szívdobogás, kissé zajos, rendben, tehát: valamit a magyar irodalomról. Monológ ${ }_{00}$. In: 2000. MM április, 12. évf. 4. sz. 52-72. o. Újraközölve: Kukorelly Endre: $666999^{000}$. Előbb némi szívdobogás, kissé zajos, rendben, tehát: valamit a magyar irodalomról. Monológ ${ }^{00}$. In: Né/ma? Tanulmányok a magyar neoavantgárd köréböl. Szerk. Deréky Pál és Müllner András. Ráció Kiadó, Budapest, 2004. 315-347. o.

Kurdy Fehér János: Kamillába mártott vatta. (Beke László Erdély Miklósról). In: Tiszatáj. 1992. XLVI. évf. 5. sz. 90-96. o.

Kürti Emese: A csend és az idő - Attalai Gábor (1934-2011). In: Magyar Narancs. 2011. szeptember 1. XXIII. évf. 35. sz. 30-31. o.

Kürti Emese: "Dezorientáljuk a csapatokat" St.Auby Tamás kiállítása Karlsruhéban $1 . \quad$ Interneten: http://exindex.hu/index.php?l=hu\&page=3\&id=773; 2012. 03. 10.

Laozi: Laozi. In: Kínai filozófia. Ókor / II. kötet. Szöveggyüjtemény. Vál., ford. Tőkei Ferenc. Magiszter Társadalomtudományi Alapítvány, Budapest, 2005. 17-50. o.

Láncz Sándor: Van-e modern realista szintézis a mai magyar képzőmüvészetben? Gondolatok Szabolcsi Miklós „Jel és kiáltás” címü könyve nyomán. In: Müvészet. 1971. december, XII. évf. 12. sz. 6-10. 0.

Legéndy Péter György: Semmi van. Emlékirat Erdély Miklósról. In: Hölgyfutár. Álom. Mamüvészeti Magazin. 1990. július-augusztusszeptember, II. évf. 2. sz. 36-37. o. 
LeWitt, Sol: Paragraphs on Conceptual Art. In: Art in Theory - 1900-1990 - An Anthology of Changing Ideas. Ed. Charles Harrison and Paul Wood. Blackwell Publishers Inc, Oxford UK \& Cambridge USA, 1999. 834-837. o.

LeWitt, Sol: Sentences on Conceptual Art. In: Art in Theory - 1900-1990 An Anthology of Changing Ideas. Ed. Charles Harrison and Paul Wood. Blackwell Publishers Inc, Oxford UK \& Cambridge USA, 1999. 837-839. o.

Lippard, Lucy R. - Chandler, Johny: The Dematerialization of Art. In: Conceptual Art: A Critical Anthology. Ed. Alexander Alberro, Blake Stimson. The MIT Press, Cambridge, Massachusetts, London, England, 1999. 46-50. o.

Liszka Tamás: Szabadságtechnikai gyakorlatok. Erdély Miklós fogalmi müvészete és müvészetfogalmai. In: Metropolis. 2007. április, XI. évf. 4. sz. 18-22. o.

Lyotard, Jean-François: Foreword: After the Words. In: Joseph Kosuth: Art after Philosophy and After - Collected Writings, 1966-1990. ed. Gabriele Guerico. The MIT Press, Cambridge, Massachusetts, London, England, 1991. XV-XVIII. o.

M. Z. [Molnár Zoltán]: Happening. In: Élet és Irodalom. 1966. szeptember 24. X. évf. 39. sz. 10. o.

Madácsy István: Transzparencia. A fény müve és a mü fénye. DLA értekezés, Magyar Képzőmüvészeti Egyetem, Doktori Iskola, Budapest, 2009.

Major Nándor: Elveszejtett ország. Fórum Könyvkiadó, Újvidék, 1993.

Marcuse, Herbert: Értekezés a felszabadításról. Az új szenzibilitás. In: Új Symposion. 1970/65. sz. 1-5. o.

Marx György, Dr.: Kvantummechanika. Müszaki Könyvkiadó, Budapest, 1957.

McCagg, William: A nem-zsidó zsidó a modern Magyarországon. A zsidóság reakciójának felmérése a magyar antiszemitizmusra. „Burzsoá radikálisok”. „Atomtudósok”. „Erdély Miklós”. Esszé a magyar-zsidó koexistencia 1848-1991-ig c. kollokvium céljaira. Kézirat, Batthyány Társaság, Budapest, 1991. október

McLuhan, Marshall: Understanding Media. The Extensios of Man. Penguin Books, New York, 1964.

Meijers, Daniel: Differences is Attitudes to Study and Work between Present-day Hasidim and Mitnaggedim: A Sociological View. In: Hasidism Reappraised. Ed. by Ada Rapoport-Albert. The Littman Library of Jewish Civilization, London - Portland, Oregon, 1997. 427-438. o. 
Mezei Balázs: Az önkorlátozó Isten. Bevezető sorok Hans Jonas írásához. In: 2000. MCMXCVI augusztus, 8. évf. 8. sz. 51-55. o.

Mezei Ottó: A Szürenon és kisugárzása. In: Ars Hungarica. 1991/1. sz. 6583. o. Újraközölve: In: Uő: Magyar, európai, modern. Válogatott írások. Vál. és szerk. Andrási Gábor, Pataki Gábor. Argumentum Kiadó, MTA Bölcsészettudományi Kutatóintézet, Müvészettörténeti Intézet, 2013. 261-278. o.

Mezei Ottó: „Gyürkőzz, János, rohanj, János”. A hatvanas évek új törekvései a Magyar Nemzeti Galériában. In: Kortárs. 1991/12. sz. 69-73. o. Újraközölve: In: Uö: Magyar, európai, modern. Válogatott írások. Vál. és szerk. Andrási Gábor, Pataki Gábor. Argumentum Kiadó, MTA Bölcsészettudományi Kutatóintézet, Müvészettörténeti Intézet, 2013. 286-289. o.

Mezei Ottó: Háromnapos bemutató a Müegyetem R épületében. (Kézirat a hagyatékban, 1970-1971) In: Uő: Magyar, európai, modern. Válogatott írások. Vál. és szerk. Andrási Gábor, Pataki Gábor. Argumentum Kiadó, MTA Bölcsészettudományi Kutatóintézet, Müvészettörténeti Intézet, 2013. 251-253. o.

Mészáros Tamás: Kitörési kísérlet - visszafelé. Turgenyev-bemutató Kaposvárott. In: Magyar Hírlap. 1981. november 7. XIV. évf. 262. sz. 10. o.

Miklós Erdély. Kiállítási katalógus, Szerk. Szőke Annamária. Georg Kargl Fine Arts, Wien - Kisterem, Budapest - tranzit.hu, Budapest - Miklós Erdély Foundation, Budapest, 2008.

Murgács Gábor: Hozzászólás Erdély Miklós Marly-i téziseihez. (Nyílt levél). In: Magyar Mühely. 1983. július, XXI. évf. 67. sz. 67-71. o.

Mújdricza Péter: Imaginárius terek. In: Új Magyar Építőmüvészet. 1999/4. sz. 41. o., 54-56. o. Újraközölve: In: Magyar Mühely. 1999. XXXVII. évf. 110-111. sz. 165-171. o.

Müllner András: A molluszkum-nyelv. Természettudomány és avantgárd müvészet. In: Parnasszus. 2011. ősz, XVII. évf. 3. sz. 55-59. o.

Müllner András: Az első happening. A magyarországi neoavantgárd akcionizmus vázlatos története. In: Né/ma? Tanulmányok a magyar neoavantgárd köréböl. Szerk. Deréky Pál és Müllner András. Ráció Kiadó, Budapest, 2004. 182-204. o.

Müllner András: Az önreflexió mint „irodalomtörténeti fordulat”. Erdély Miklós: Metán. In: Fogaras György - Müllner András: Rátévedések a romantikában, a neoavantgárdban és más területeken. Ictus Kiadó és JATE Irodalomelmélet Csoport, Szeged, 1998. 147-174. o.

Müllner András: Fotómozaikokról mozaikosan. In: Müút. 2008/008. sz. 5659. 0.

Müllner András: Nagytestü prémes állatok. Néhány szó Tandoriról és Erdélyről egy recenzió keretében. In: Fogaras György - Müllner 
András: Rátévedések - a romantikában, a neoavantgárdban és más területeken. Ictus Kiadó és JATE Irodalomelmélet Csoport, Szeged, 1998. 132-146. o.

Nagy Pál: Erdély Miklós: Tézisek az 1980-as marly-i konferenciához. In: Magyar Mühely. 1999. XXXVII. évf. 110-111. sz. 17-23. o.

Nagy Pál: Párhuzamos életrajzok. Robert Filliou, Erdély Miklós. In: Magyar Napló. 1991. november 29. III. évf. 16. sz. 32-33. o.

Nemes Z. Márió: Belecsúszni a humuszba. Az ebéd (in memoriam Batu kán) címü happeningről (1966). In: Flash Art Hungary. 2014. III. évf. 2-3. sz. 13. sz. 14-17. o.

Németh Gábor: Szellemjárás. Magyar avantgárd a ’70-es években. In: Petőfi Rádió. 2003. július 10.

Németh Gábor - Sebők Zoltán: Az utca müvészete. (Németh Gábor és Sebők Zoltán beszélgetése). In: Új Forrás. 2004. október, XXXVIII. évf. 8. sz. 95-107. o.

Németh Lajos: „Stúdió, 1966”. A fiatal müvészek stúdiójának VI. kiállítása. In: Kritika. 1966. június, IV. évf. 6. sz. 49-51. o.

Népakarat. 1956. november 3. I. évf. 3. sz. o.n.

Önkéntes Törvényhozó Testület Alapítólevele (1982. szeptember). In: KREATIVITÁSI GYAKORLATOK, FAFEJ, INDIGO - Erdély Miklós müvészetpedagógiai tevékenysége 1975-1986. Összeállította Hornyik Sándor, Szőke Annamária. MTA Művészettörténeti Kutatóintézet Gondolat Kiadó - 2B Alapítvány - Erdély Miklós Alapítvány, Budapest, 2008. 386. o.

Összefoglaló jelentés és intézkedési terv. In: V-156455 számú dosszié. 1968. május 11-i keltezésü, a Történeti Hivatal örizetében lévő irat.

Örizetlen százasok a pesti utcán. In: Magyar Nemzet. 1956. november 3. XIX. évf. 257. sz. 3. o.

(Pachner): Több volt, mint müvészet. Hol rontottuk el? In: Pest Megyei Hírlap. 1992. október 26.

Passuth Krisztina: A „Stúdió 66” festményeinek kiállítása az Ernst Múzeumben. In: Tiszatáj. 1966. június, XX. évf. 6. sz. 459-460. o.

Pauer Gyula: Erdély Miklósról 12 év után. In: Balkon. 1998/10. sz. 22. o.

Pauer Gyulával beszélget Antal István. In: Balkon. 1994/7. sz. 15. o.

Pályi András: Happening és színház. Gondolatok a „Három kvarkot Marke királynak!” kapcsán. In: Színház. 1969. április, II. évf. 4. sz. 46-49. o.

Penrose, Roger: A császár új elméje. Számítógépek, gondolkodás és a fizika törvényei. Ford. Gálfi László. Akadémiai Kiadó, Budapest, 2011.

Performance-os esték és Pataki Ági rejtélye. In: MaNcs. 2000. február 24. XII. évf. 8. sz. 45. o. 
Perjés Zoltán: Bezárul a tér. In: Delta. 1974. január, 8-10. o.

Perneczky Géza: A ferde mennyország. In: Magyar Mühely. 1983. július, XXI. évf. 67. sz. 23-26. o.

Perneczky Géza: A fotómozaikról. Kézirat, Arpool, é.n.

Perneczky Géza: A líraiság és a konstruktivizmus új útjai a magyar festészetben. In: Képzömüvészeti Almanach 1. Corvina, Budapest, 1969.

Perneczky Géza: Erdély Miklós, és müve, a dekonstruktív tautológia. In: Erdély Miklós /1928-1986/. Kiállítási katalógus, Csók István Képtár, István Király Múzeum, Székesfehérvár, 1991. október 26. - december 31. 5-24. o. Újraközölve: Perneczky Géza: Erdély Miklós és müve: A dekonstruktív tautológia. In: Perneczky Géza: Zuhanás a toronyból. Válogatott írások 1983-1994. Enciklopédia Kiadó, Budapest, 1994. 105-122. 0 .

Perneczky Géza: Fiatalok stúdiója, 1966. Kiállítás az Ernst Múzeumban. In: Magyar Nemzet. 1966. április 22. XXII. évf. 94. sz. 4. o.

Perneczky Géza: Ipics-apacs pop-art. In: Balkon. 1994/2. sz. 12, 9-15. o.

Perneczky Géza: Müfaji kérdések. In: Élet és Irodalom. 1970. március 7. XIV. évf. 10. sz. 12. o.

Perneczky Géza: Produktivitásra ítélve? Az Iparterv-csoport és ami utána következett Magyarországon. 1. rész. In: Balkon. 1996/1-2. sz. 5-22. o.

Perneczky Géza: Produktivitásra ítélve? Az Iparterv-csoport és ami utána következett Magyarországon. 2. rész. In: Balkon. 1996/3. sz. 15-28. o.

Perneczky Géza: Új műfaj: A fotómozaik. In: Tükör. 1970. november 3. 44. sz. 30. 0.

Peternák Miklós: A konceptuális müvészet hatása Magyarországon. 198385. Interneten: http://www.c3.hu/collection/koncept/help.html; 2012. 11. 23.

Peternák Miklós: A magyar avant-garde film. In: F.I.L.M. A magyar avantgarde film története és dokumentumai. Szerk. Peternák Miklós. Képzőmüvészeti Kiadó, Budapest, 1991. 5-51. o.

Peternák Miklós: Beszélgetés Erdély Miklóssal 1983 tavaszán. In: Árgus. 1991. szeptember-október, II. évf. 5. sz. 75-88. o.

Peternák Miklós: concept.hu| koncept.hu. A konceptuális müvészet hatása Magyarországon. The Influence of Conceptual Art in Hungary. Paksi Képtár - C3 Alapítvány, 2014.

Peternák Miklós: Előszó. In: Erdély Miklós: A filmről. (Filmelméleti írások, forgatókönyvek, filmtervek, kritikák). Válogatott írások II. Összeáll. Peternák Miklós. Szerk. Beke László, Szőke Annamária. 
Balassi Kiadó - BAE Tartóshullám - Intermédia, Budapest, 1995. 78. 0 .

Peternák Miklós: Interdiszciplinaritás. Új médiumok az elmúlt három évtized magyar müvészetében - vagy kire hatott Erdély Miklós és kire nem? In: A második nyilvánosság - XX. századi magyar müvészet. Összeállította Hans Knoll. Enciklopédia Kiadó, Budapest, 2002. 248-269. o.

Peternák Miklós: Jegyzetek, dokumentumok. In: Erdély Miklós: A filmröl. (Filmelméleti írások, forgatókönyvek, filmtervek, kritikák). Válogatott írások II. Összeáll. Peternák Miklós. Szerk. Beke László, Szőke Annamária. Balassi Kiadó - BAE Tartóshullám - Intermédia, Budapest, 1995. 38-66. o.

Peternák Miklós: Kísérlet és kutatás a XX. századi magyar müvészetben. Az intermediális technikától a komputerképig. In: Magyar Mühely. 1992. június, XXXI. évf. 84. sz. 27-49. o.

Peternák Miklós: Képháromszög. Ráció Kiadó, Budapest, 2007.

Peternák Miklós: Szerkesztői jegyzetek. In: Erdély Miklós: Müvészeti irások. (Válogatott müvészetelméleti tanulmányok I.). Szerk. Peternák Miklós. Képzőmüvészeti Kiadó, Budapest, 1991. 205-214. o.

Petőcz András: A titok. Jegyzet Erdély Miklósról. In: Balkon. 1998/10. sz. 20-21. o.

Petőcz András: Jegyzet Erdély Miklósról. In: Holmi. 1990. szeptember, II. évf. 9. sz. 1037-1044. o. Újraközölve: In: Petőcz András: A jelbenlétezés méltósága. írások, 1982-1990. Colosseum, Budapest, 1990. 112-119. 0.

Petőfi S. János: Szöveg és jelentés. In: Magyar Mühely. 1981. július, XIX. évf. 64. sz. 36-59. o.

Péntek Imre: Erdély Miklós: A művészsors tiszta modellje. Beszélgetés feleségével, Szenes Zsuzsa textiltervező iparmüvésszel. In: Fejér Megyei Hírlap. Erdély Miklós kiállítása elé címü összeállítás. 1991. október 26.

Pfeiffer Izsák: Martin Buber. In: Martin Buber: Száz chászid történet. Ford. Pfeiffer Izsák. Magyar Zsidók Pro Palesztina Szövetsége, Budapest, 1944. 5-30. o.

Piotrowski, Piotr: In the Shadow of Yalta - The Avant-garde in Eastern Europe, 1945-1989. Transl. Anna Brzyski. Reaktion Books, London, 2009.

Plágium 2000: Jegyzet. A sokszorozványokról/multiplikákról röviden. Interneten: $\quad$ http://multiplika2000.wordpress.com/asokszorozvanyokrol-multiplikakrol-roviden; 2012. 03. 10. 
Pomogáts Béla: Ismeretelmélet mágikus térben. Jegyzet Erdély Miklós költészetéről. In: Magyar Mühely. 1999. XXXVII. évf. 110-111. sz. 13-16. o.

Postmodernism and the Postsocialist Condition. Edited by Ales Erjavec. University of California Press, Berkeley/Los Angeles/London, 2003.

R. Kiállítási katalógus, Műegyetem R épület, Budapest, 1970. december 15-17.

R. [Rózsa Gyula]: Kondor Béla 1931-1972. In: Kritika. 1973/2. sz. 14. o.

Reha György: A „művészet bizony marhaság” - adalékok a Hadititokhoz. In: Artmagazin. 2014. XII. évf. 7. sz. 71. sz. 16-17. o.

Rorty, Richard: A filozófia és a természet tükre. Ford. Fehér Márta. In: Filozófiai figyelö. 1985/3. sz. 51-80. o.

Rózsa Gyula: A valóság nem válaszol. Kasseli és budapesti jegyzetek a müvészetröl. In: Népszabadság. 1972. november 19. Vasárnapi melléklet. 7. 0.

Rózsa Gyula: Válasz. In: Kritika. 1973/4. sz. 2. o.

Rózsa Gyula: Végletek és távlatok. Fiatal képzőmüvészek az Ernst Múzeumban. In: Népszabadság. 1966. május 7. XXIV. évf. 107. sz. 7. o.

Rózsa T. Endre: Az utak összeérnek? In: Kritika. 1971/6. sz. 54-57. o. Újraközölve: In: Ars Hungarica. 1991/1. sz. 126-129. o.

Rugási Gyula: A pillanat foglya. Gondolt-Cura Alapítvány - Palatinus Kiadó, Budapest, 2002.

Sainsbury, R. M.: Paradoxonok. TYPOTEX Kiadó, Budapest, 2002.

Schelling, F. W. J.: A müvészet filozófiája. (A kéziratos hagyatékból). Ford. Révai Gábor. Akadémiai Kiadó, Budapest, 1991.

Schelling, F. W. J.: Bruno avagy a dolgok isteni és természetes elvéröl. /Beszélgetés/. Ford. Jaksa Margit. Magyar Helikon, Budapest, 1974.

Schiller, Friedrich: Levelek az ember esztétikai neveléséröl. In: Schiller válogatott esztétikai írásai. Ford. Szemere Samu. Budapest, 1960.

Scholem, Gershom: A kabbala helye az európai szellemtörténetben. Válogatott írások I. Szerk. Adamik Lajos. Ford. Adamik Lajos, Bendl Júlia, Berényi Gábor, Turán Tamás. Atlantisz, Budapest, 1995.

Scholem, Gershom: A kabbala helye az európai szellemtörténetben. Válogatott írások II. Szerk. Adamik Lajos. Ford. Adamik Lajos, Bendl Júlia, Berényi Gábor, Turán Tamás. Atlantisz, Budapest, 1995.

Schrenck Notzing, Baron von: Phenomena of Materialisation. A contribution to the investigation of mediumistic teleplastics. Transl. E. E. Fournier d'Albe, D.Sc. London, Kegan Paul, Trench, Trubner \& Co. Ltd., New York, E. P. Dutton \& Co. 1923. 
Schrödinger, Erwin: Válogatott tanulmányok. Vál., szerk. Törös Róbert. Ford. Nagy Imre. Gondolat, Budapest, 1970.

Sebők Zoltán: Új misztika felé - Beszélgetés Erdély Miklóssal. In: Híd. 1982/3. sz. 366-376. o. Az interjú egy részlete újraközölve: In: Erdély Miklós: A filmröl. (Filmelméleti irások, forgatókönyvek, filmtervek, kritikák). Válogatott írások II. Összeáll. Peternák Miklós. Szerk. Beke László, Szőke Annamária. Balassi Kiadó - BAE Tartóshullám - Intermédia, Budapest, 1995. 64-66. o.

Silber, Laura - Little, Allan: Jugoszlávia halála. Ford. Tabák Gábor, Mucsi Ferenc, Stern Gábor. Zrínyi Kiadó, Budapest, 1996.

Simmel, Georg: Rembrandt. Egy müvészetfilozófiai kisérlet. Ford. Berényi Gábor. Corvina, Budapest, 1986.

Simonovits András: Válogatott fejezetek a matematika történetéböl. TYPOTEX Kiadó, Budapest, 2009.

Sinkovits Péter: A magyar avantgárd Székesfehérvárból nézve. In: Müvészet. 1988. május, XXIX. évf. 5. sz. 32-37. o.

Sinkovits Péter: Az Iparterv csoport kialakulása és utóélete. In: Iparterv csoport - Progresszivitás és illúzió. A magyar avant-garde harmadik nemzedéke. 1968-1969. Kiállítási katalógus, Párizsi Magyar Intézet, Párizs, 2010. 26-28. o.

Sinkovits Péter: Képzuhatag. A magyar festészet új hullámai az Ernst Múzeumban. In: Müvészet. 1984/12. sz. 46-49. o.

Six Years: The Dematerialization of the Art Object from 1966 to 1972. Ed. Lucy R. Lippard. Praeger, New York, 1973. 263-264. o. Az utószó újraközölve: In: Conceptual Art: A Critical Anthology. Ed. Alexander Alberro, Blake Stimson. The MIT Press, Cambridge, Massachusetts, London, England, 1999. 294-295. o.

Sokcsevits Dénes - Szilágyi Imre - Szilágyi Károly: Déli szomszédaink története. Bereményi Könyvkiadó, Budapest, 1994.

Somogyi György: Elektronikus mozaikok. In: Müvészet. 1981/5. sz. 47-48. o.

Somogyi Győző: Hármas kép Erdély Miklósról. In: Új Müvészet. 1992. III. évf. 4. sz. 14-15. o.

Sőrés Zsolt: Ellentmondás-vizsgálat. Egy majdani disszertáció expozéja a 21. századból. In: Magyar Mühely. 1999. XXXVII. évf. 110-111. sz. 109-114. o.

Studió 66. A Fiatal Müvészek Studiójának VI. kiállítása. Kiállítási katalógus, Ernst Múzeum, Budapest, 1966.

Sugár János: Ahonnan minden egyfele van. In: Mínusz pátosz. Balassi Kiadó - Intermedia, Budapest, 1995. 16-22. o. A szöveg korábbi variánsa: Sugár János: Mínusz pátosz. In: Hasbeszélő a gondolában. A Tartóshullám antológiája. (Jóvilág 3.). (Cápa 4.). Szerk. Beke 
László, Csanády Dániel, Szőke Annamária. Bölcsész Index, Budapest, 1987. 285-288. o.

Sugár János: Emigráció a festészetbe. Erdély megvalósult és meg nem valósult müvei. In: Új Müvészet. 1999. március, X. évf. 3. sz. 8-10. o. Újraközölt változatok: Sugár János: Emigráció a festészetbe. Erdély megvalósult és meg nem valósult müvei. In: Magyar Mühely. 1999. XXXVII. évf. 110-111. sz. 104-108. o.; Sugár János: Emigráció a festészetbe. In: KREATIVITÁSI GYAKORLATOK, FAFEJ, INDIGO Erdély Miklós müvészetpedagógiai tevékenysége 1975-1986. Összeállította Hornyik Sándor, Szőke Annamária. MTA Művészettörténeti Kutatóintézet - Gondolat Kiadó - 2B Alapítvány Erdély Miklós Alapítvány, Budapest, 2008. 453-457. 0.

Suzuki, D. T.: An Introduction to Zen Buddhism. Ed. Christmas Humphreys. Rider \& Company, London, 1979.

Szabó György: Fiatalok próbája az Ernst Múzeum-ban. In: Élet és Irodalom. 1966. május 7. X. évf. 19. sz. 3. o.

Szabó Júlia: Emlékek a 70-es évekből. In: Müvészet. 1980. október, XXI. évf. 10. sz. 10. o.

Szabó Júlia: Erdély Miklós: Időutazás, 1-5, 1976. (Székesfehérvár, István Király Múzeum). In: Magyar Mühely. 1999. XXXVII. évf. 110-111. sz. 146-149. o.

Szabó Júlia: Idézetek a hetvenes évek müvészetének irodalmából. In: Müvészet. 1980. október, XXI. évf. 10. sz. 16-19. o.

Szabó Marcell, Urfi Péter: „Minek nézzem? Látom, hogy jó!” (interjú Peternák Miklóssal). In: Puskin Utca. 2008/4. sz. 15-17. o.

Szegő György: Az „,igazság áramlási iránya”. In: Magyar Nemzet. 1988. október 25. LI. évf. 255. sz. 4. o.

Szegö György: Fotó/szeánsz: Erdély Miklós. In: Magyar Mühely. 1999. XXXVII. évf. 110-111. sz. 139-145. o. Korábbi közlés: In: Fotómüvészet. 1992/3. sz. 49-54. o.

Szentjóby Tamás: A Happeningről (részletek). In: Az ebéd (In memoriam Batu kán). HAPPENING Budapest H 1966. The Lunch (In Memoriam Batu Khan). Szerk. László Zsuzsa, St. Turba Tamás. Ford. Polonyi Csaba. Tranzit Hungary Közhasznú Egyesület, Budapest, 2011. 1014. o., 45-49. o.

Székely Katalin: A valóság válaszol. Koncept koncepció, szemelvények. In: Balkon. 2008/6. sz. 2-3. o.

Szilágyi Sándor: Neoavantgárd tendenciák a magyar fotómüvészetben 1965-1984. Fotókultúra - Új Mandátum Könyvkiadó, Budapest, 2007.

Szipőcs Krisztina: Történetek Erdély Miklósról. In: Balkon. 1998/11. sz. 48. 0 . 
Színház- és filmrendezők Pauer Gyuláról. Ascher Tamás. A beszélgetéseket készítette és lejegyzetelte Antal István. In: Pauer. Összeállította Szőke Annamária. Szerkesztette Szőke Annamária és Beke László. MTA Művészettörténeti Kutatóintézet, Budapest, 2005. 351-358. o.

Szkárosi Endre: A Magyar Mủhely szerepe a magyar performanszkultúra alakításában - az Artpool dokumentumainak tükrében. In: Magyar Mühely. 1012/3. sz. L. évf. 161. sz. 57-61. o.

Szombathy Bálint: Erdély Miklós Fényismeret-költeménye. In: Magyar Mühely. 1999. XXXVII. évf. 110-111. sz. 29-31. o.

Szőke Annamária: Az Erdély Miklós-hagyaték. Az MKE Intermédia Tanszékén az Erdély Miklós Alapítvány által szervezett Erdély 80|80 címü szemináriumon elhangzott előadás. (2008. június 5.) Interneten: http://catalog.c3.hu/index.php?page=work\&id=38\&lang=HU; 2013. 04. 05.

Szőke Annamária: Erdély Miklós festészetéről. In: Erdély Miklós. Kiállítási katalógus, Óbuda Galéria, Zichy Kastély, 1986. április 11. - május 5. 35-38. o.

Szőke Annamária: Erdély Miklós müveinek restaurálása és rekonstrukciója. In: Magyar Mühely. 1999. XXXVII. évf. 110-111. sz. 115-138. o.

Szőke Annamária: Erdély Miklós pécsi előadásaihoz kapcsolódó kiállítások: „költészet” és „film” (1979. november és december). In: KREATIVITÁSI GYAKORLATOK, FAFEJ, INDIGO - Erdély Miklós müvészetpedagógiai tevékenysége 1975-1986. Összeállította Hornyik Sándor, Szőke Annamária. MTA Művészettörténeti Kutatóintézet Gondolat Kiadó - 2B Alapítvány - Erdély Miklós Alapítvány, Budapest, 2008. 247-251. o.

Szőke Annamária: Erdély Miklós: Tavalyi hó. 1970. In: VISZONTLÁTÁSRA! DUCHAMP. Készült a VISZONTLÁTÁSRA! • Marcel Duchamp magyarországi hatásai c. kiállításhoz, Budapest Galéria Kiállítóháza, 1996. november 14. - december 8. Budapest Galéria, Budapest, 1996-2000. 55-56. o.

Szőke Annamária: Koncept, akció, életmód. Beszélgetés Legéndy Péterrel. In: Belvedere. 1991. III. évf. 1. sz. 43-49. o.

Szőke Annamária: piros fehér zöld. In: Sub minervae nationis praesidio. Tanulmányok a nemzeti kultúra kérdésköréböl Németh Lajos 60. születésnapjára. Az ELTE és az ELTE Müvészettörténeti Tanszék közös kiadása, Budapest, 1989. 333-340. o. Képekkel kibővített variánsa az interneten: http://arthist.elte.hu/Tanarok/SzoekeA/fulltexts/PFZ.htm; 2012. 08. 11.

Szőke Annamária: Tapogatózás legyen. In: Célok. 1989. január, II. évf. 2. sz. 21-23. 0. 
Szőke Annamária: „Titok a jövő jelenléte”. Tudomány a müvészet határain belül Erdély Miklós müvészetében. In: Né/ma? Tanulmányok a magyar neoavantgárd köréböl. Szerkesztette Deréky Pál és Müllner András. Ráció Kiadó, Budapest, 2004. 240-272. o. Korábban megjelent változatok: In: Nappali Ház. 1997/1. sz. IX. évf. 1. sz. 4265. o. Németül: „Die Gegenwart der Zukunft: ein Rätsel”. Wissenschaft innerhalb der Kunst im Werk von Miklós Erdély. In: Acta Historiae Artium. Tomus 39, Akadémiai Kiadó, Budapest, 1997. 197-221. o. Rövidítve: In: Peter Weibel (Szerk.): Jenseits von Kunst. Passagen Verlag, Wien, 1997. 609-613. o.; In: A müvészeten túl. Kortárs Mủvészeti Múzeum - Ludwig Múzeum Budapest, Soros Alapítvány C3 Kulturális és Kommunikációs Központ, Budapest, é. n. (2000) 607-613. o.; Interneten: Ponticulus Hungaricus. 2007. március, XI. évf. $3 . \quad$ sz. http://members.iif.hu/visontay/ponticulus/rovatok/hidverok/erdely_mi klos.html; 2014. 09. 17.

Szőke Annamária - Erdély Dániel: Az Indigo csoport és a „társadalmi visszásságok”. In: KREATIVITÁSI GYAKORLATOK, FAFEJ, INDIGO - Erdély Miklós müvészetpedagógiai tevékenysége 1975-1986. Összeállította Hornyik Sándor, Szőke Annamária. MTA Müvészettörténeti Kutatóintézet - Gondolat Kiadó - 2B Alapítvány Erdély Miklós Alapítvány, Budapest, 2008. 367-383. o.

Szőnyei Tamás: „Hátha felfedezem az örökmozgót”. Harasztÿ István szobrászmüvész. (Interjú Harasztÿ Istvánnal.) In: Magyar Narancs. 1998. május 21. X. évf. 21. sz. 8-9. o.

Szőnyei Tamás: Tilos müvészet. „A kvalitás nem rendőri ügy”. Peternák Miklós, Erdély Dániel. (Interjú Peternák Miklóssal és Erdély Dániellel.) In: Magyar Narancs. 1998. május 7. X. évf. 19. sz. 8-9. o.

Szürenon. Kiállítási katalógus, Kassák Lajos Művelődési Otthon, Budapest, 1969. október 2-20.

Szürenon 1969-1979. Kiállítási katalógus, Szerk. Mezei Ottó. Kassák Lajos Mủvelődési Ház, Budapest, 1979.

Tarjányi Eszter: A szellem örvényében. A magarországi mesmerizmus, szellemidézés, teozófia története és müvészeti kapcsolatai. Universitas Könyvkiadó, Budapest, 2002.

Tatai Erzsébet: Hordozható Múzeum. A pop-art, konceptuális művészet, akcionalizmus Magyarországon a 60-as években. In: Új Müvészet. 2003/12. sz. 22-23. o.

Tatai Erzsébet: Láthatatlan müvek kiállítása. Koncept koncepció, szemelvények. In: Balkon. 2008/6. sz. 4-6. o.

Tatai Erzsébet: Neokonceptuális művészet Magyarországon. In: [CONCEPTUAL ART AT THE TURN OF MILLENIUM]. [KONCEPTUÁLNE UMENIE NA ZLOME TISÍCROČÍI]. [KONCEPTUÁLIS MÜVÉSZET AZ EZREDFORDULÓN]. AICA 
Section Hungary, Slovak Section of AICA, Budapest, Bratislava, 2002. 115-141. o.

Tatai Erzsébet: Neokonceptuális müvészet Magyarországon a kilencvenes években. Præsens, Budapest, 2005.

Tatár György: A nagyon távoli város. Vallásfilozófiai írások és viták. Atlantisz, Budapest, 2003.

Tábor Ádám: A váratlan kultúra - Esszék a magyar neoavantgárd irodalomról és müvészetről. Balassi Kiadó, Budapest, 1997.

Tábor Ádám: Váratlan! Kérdés! In: Magyar Mühely. 1983. július, XXI. évf. 67. sz. 54-59. o.

Téma: A költészet. Az Indigo csoport beszélgetése az Erdély Miklós Költői avantgarde című pécsi előadásához kapcsolódó kiállításról 1979. november 7-én. In: KREATIVITÁSI GYAKORLATOK, FAFEJ, INDIGO - Erdély Miklós müvészetpedagógiai tevékenysége 19751986. Összeállította Hornyik Sándor, Szőke Annamária. MTA Művészettörténeti Kutatóintézet - Gondolat Kiadó - 2B Alapítvány Erdély Miklós Alapítvány, Budapest, 2008. 252-278. 0.

Tillmann J. A.: „Nem hiszem, hogy még egy ilyen ember van a világon.” Erdély Miklós és A kalcedoni zsinat emlékére. In: Pannonhalmi Szemle. 1999. VII. évf. 1. sz. 100-105. o.

Tillmann J. A.: „Nem hiszem, hogy még egy ilyen ember van a világon.” Erdély Miklós és A kalcedoni zsinat emlékére. In: Magyar Mühely. 1999. XXXVII. évf. 110-111. sz. 37-43. o.

Tillmann J. A.: Erdély Miklós és A kalcedoni zsinat. In: Tillmann J. A.: Merőleges elmozdulások. Utak a modern müvészetben. Új PalatinusKönyvesház Kft., Budapest, 2004. 79-90. o. Interneten: http://www.c3.hu/ tillmann/irasok/muveszet/erdely.html; 2012. 11. 12.

Tiltás és Türés. A Fiatal Képzömüvészek Stúdiójának 1966-os és 1967-es kiállítása. Kiállítási katalógus, Szerk. Csanádi-Bognár Szilvia. Ernst Múzeum, Budapest, 2006.

Tolnai Ottó: Néhány megjegyzés Bori Imre A legújabb magyar líráról címü írásához. In: Új Symposion. 1968. február, 34. sz. 12-13. o. Altorjay először itt, a szerző explicit feltüntetése nélkül megjelent visszaemlékezése újraközölve: Altorjay Gábor: The Lunch (In Memoriam Batu Khan). The first happening in Hungary. The Recollection of Gábor Altorjay. In: Parallel Chronologies. An exhibition in newspaper format. Budapest, 2009. 16-17. o.; Altorjay Gábor: Az ebéd (In memoriam Batu kán). Altorjay Gábor visszaemlékezése. The Lunch (In Memoriam Batu Khan). The Recollection of Gábor Altorjay. In: Az ebéd (In memoriam Batu kán). HAPPENING Budapest $H$ 1966. The Lunch (In Memoriam Batu Khan). Szerk. László Zsuzsa, St. Turba Tamás. Ford. Polonyi Csaba. 
Tranzit Hungary Közhasznú Egyesület, Budapest, 2011. 7-9. o., 4244. 0 .

Törvénytelen avantgárd. Galántai György balatonboglári kápolnamüterme 1970-1973. Szerk. Klaniczay Júlia és Sasvári Edit. Artpool-Balassi, Budapest, 2003.

Ungváry Rudolf: A személyes művész. Erdély Miklós nem triviális helye a struktúrában, avagy A találékonyságba belekapaszkodó ember. In: Magyar Mühely. 1999. XXXVII. évf. 110-111. sz. 176-188. o. Újraközölve: In: Kritika. 1999/2. sz. 34-36. o.

Vadas József: Új magyar avantgarde? In: Új írás. 1971/5. sz. 93-101. o.

Vakáció. A balatonboglári kápolnatárlatok története, 1970-1973. Szakértőriporter: Sasvári Edit. Szerkesztő: Római Róbert. Operatőr: Gombos Tamás. Rendező: Soós Árpád. MTV, V. Stúdió, Fríz Produceri Iroda, 1998.

Visszaemlékezések. In: Törvénytelen avantgárd. Galántai György balatonboglári kápolnamüterme 1970-1973. Szerk. Klaniczay Júlia és Sasvári Edit. Artpool-Balassi, Budapest, 2003. 191-210. o.

Vekerdi László: Pillanatképek a „hatvanas évek” természettudományairól. In: Hatvanas évek. Új törekvések a magyar képzömüvészetben. Kiállítási katalógus, Magyar Nemzeti Galéria, 1991. március 14. június 30. Összeáll. Beke László, Dévényi István, Horváth György. Szerk. Nagy Ildikó. Képzőmüvészeti Kiadó - Magyar Nemzeti Galéria - Ludwig Múzeum, Budapest, 1991. 11-20. o.

Watts, Alan W.: A zen útja. Ford. Kepes János. Polgár Kiadó, 1997.

Weitz, Morris: The Role of Theory in Aesthetics. In: The Journal of Aesthetics and Art Criticism. 1956. szeptember, 15. évf. 1. sz. 27-35. o.

Wittgenstein, Ludwig: Filozófiai vizsgálódások. Ford. Neumer Katalin. Atlantisz Könyvkiadó, Budapest, 1988.

Wittgenstein, Ludwig: Logikai-filozófiai értekezés. (Tractatus logicophilosophicus). Ford. Márkus György. Akadémiai Kiadó, Budapest, 1989.

Zombori Mónika: Stúdió kiállítások a korabeli dokumentumok tükrében. 1. rész: A hatvanas évek. In: Artmagazin. 2015. XIII. évf. 8. sz. 82. sz. 30-35. 0.

(Zsadányi) [Zsadányi Oszkár]: Horogkereszt egy kiállításon. In: Új élet. 1984. október 15. XXXIX. évf. 20. sz. 4. o. 